\title{
The role of blended learning in vocabulary acquisition and student autonomy development in an ESP context
}

Grabar, Ivana

Doctoral thesis / Disertacija

2021

Degree Grantor / Ustanova koja je dodijelila akademski / stručni stupanj: University of Zagreb, Faculty of Humanities and Social Sciences / Sveučilište u Zagrebu, Filozofski fakultet

https://doi.org/10.17234/diss.2021.7739

Permanent link / Trajna poveznica: https://urn.nsk.hr/urn:nbn:hr:131:134943

Rights / Prava: In copyright/Zaštićeno autorskim pravom.

Download date / Datum preuzimanja: 2023-04-26

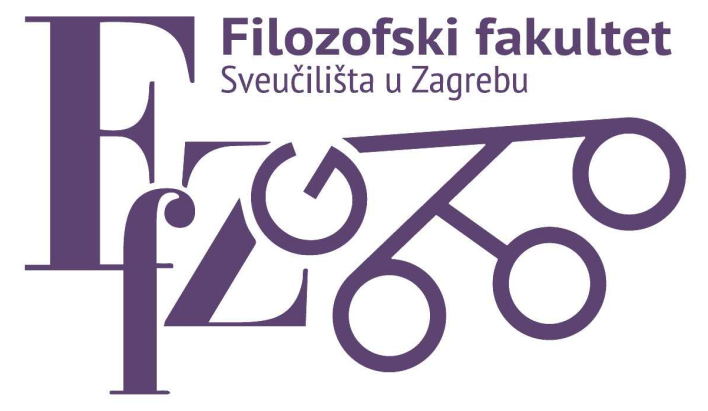

Repository / Repozitorij:

ODRAZ - open repository of the University of Zagreb

Faculty of Humanities and Social Sciences
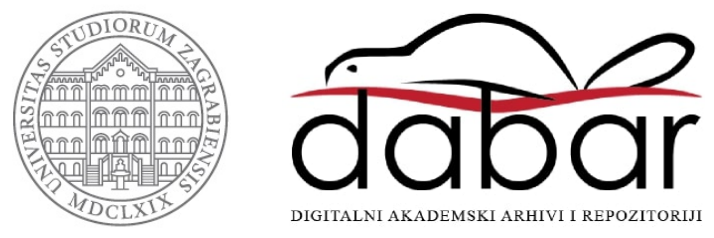


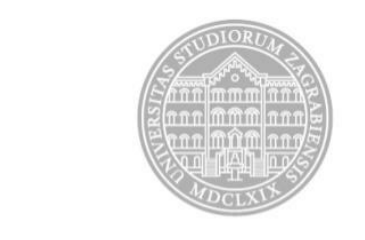

University of Zagreb

FACULTY OF HUMANITIES AND SOCIAL SCIENCES

Ivana Grabar

\section{THE ROLE OF BLENDED LEARNING IN VOCABULARY ACQUISITION AND STUDENT AUTONOMY DEVELOPMENT IN AN ESP CONTEXT}

DOCTORAL THESIS

Zagreb, 2021 


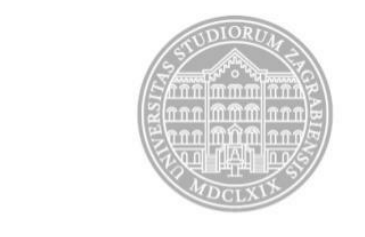

University of Zagreb

FACULTY OF HUMANITIES AND SOCIAL SCIENCES

Ivana Grabar

\title{
THE ROLE OF BLENDED LEARNING IN VOCABULARY ACQUISITION AND STUDENT AUTONOMY DEVELOPMENT IN AN ESP CONTEXT
}

\author{
DOCTORAL THESIS \\ Supervisors: Prof. Regine Hampel, PhD \\ Assoc. Prof. Marta Medved Krajnović, PhD
}

Zagreb, 2021 


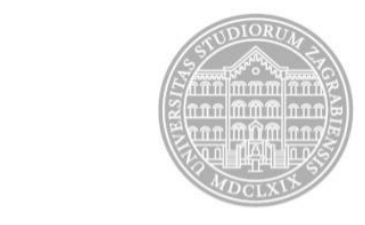

Sveučilište u Zagrebu

FILOZOFSKI FAKULTET

Ivana Grabar

\section{ULOGA HIBRIDNOGA UČENJA U USVAJANJU VOKABULARA I RAZVOJU SAMOSTALNOSTI U UČENJU ENGLESKOGA KAO STRANOGA JEZIKA STRUKE}

DOKTORSKI RAD

Mentorice: prof. dr. sc. Regine Hampel izv. prof. dr.sc. Marta Medved Krajnović 


\section{Acknowledgements}

I would like to express my gratitude to all those who have provided me with a great deal of support and assistance in any possible way.

I would first like to thank my supervisors, Full Professor Regine Hampel, PhD, and Associate Professor Marta Medved Krajnović, PhD, for their expertise, collaboration, advice, help and understanding. Regine, as my first supervisor, I have to say a special THANK YOU for your tremendous support and for not giving up on me. You were there for me as my supervisor and very often as a friend. I hope that now you'll be able to relax and enjoy without me and my thesis.

Next, I have to thank the management of University North without whose financial support this thesis would not be possible.

My next thank you goes to my long-time friends, my BABE (you know who you are), for listening to me and for being there for me during my struggles. The same goes for my dear friend and colleague Marijana: thank you for our conversations about my thesis and support whenever I needed it (even in those times when I didn't know I needed it). I should not forget to thank my training buddies and the best coach ever who helped me struggle with my thesis in a slightly different way. And a big thanks to all the other people who were there for me in some other ways (my cousin Steph, my friends and colleagues Antonia, Natalija, Snježana). Thank you all.

And the rest will be in Croatian so that I'm not misunderstood by my family...

Hvala mojoj sestri Maji i šogoru Romanu na svakom čuvanju moje djece kad je trebalo i odlascima na plesne turnire umjesto mene. Veliko hvala mami Nevenki i tati Zlatku za sve što su učinili za mene i za svu njihovu potporu koju sam imala tijekom školovanja te tijekom ove neplanirano dugačke faze života jer bez njihove vjere u mene ove disertacije ne bi bilo.

I na kraju, last but not the least, hvala mojim najdražima - mojim najboljim curama Dori i Tonki što su imale razumijevanja i strpljenja za mamu koja je često 'trebala mir' te mom voljenom Mariju koji je do samog kraja vjerovao da ja to mogu. Gotovo je! Ovo je za vas i sada je svo vrijeme koje imam samo vaše. 


\section{Mentors' Biography}

Regine Hampel is Full Professor of Open and Distance Language Learning at the Open University, and currently holds the role of Associate Dean (Research Excellence) in the Faculty of Wellbeing, Education and Language Studies. From 2013 to 2016 she was Associate Dean (Research \& Scholarship) in the Faculty of Education and Language Studies; from 2010 to 2013 she was Director for Postgraduate Studies in the Centre for Research in Education and Educational Technologies (CREET). She was a member of the Department of Languages until 2010 where she convened the Open Languages Research Group and was involved in the German programme offered by the Open University. This included designing and chairing a new level 2 German course that used an innovative blended approach.

She is a Fellow of the Higher Education Academy. Her research focuses on the use of digital technologies for language learning and teaching, contributing to new theoretical and pedagogical perspectives that go beyond narrow cognitive approaches and take account of sociocultural theories of learning and ecological principles as well as the multimodal nature of the new media. She is particularly interested in the affordances of these tools and the potential they offer for learner interaction, communication and real-world learning, as well as the implications for task design, online teaching skills, and new literacies. This work has fed into a wide range of presentations and publications, including a forthcoming book on Disruptive Technologies and the Language Classroom: A Complex Systems Theory Approach (Palgrave Macmillan).

Marta Medved Krajnović started working at the Faculty of Humanities and Social Sciences, University of Zagreb, in 1996 and was elected Associate Professor in Applied Linguistics at the same university in 2011. From 2010 to 2013 she was Director of the Postgraduate Programme in Applied Linguistics. She has presented at national and international research conferences, and has written extensively on the topic of second language acquisition and multilingualism. Since 2003 she has supervised numerous MA and PhD students. 
Marta has extensive international experience having lived in Croatia, USA, England, Ireland, Japan, Hungary, Sweden and China. From 2003-2007 she was a board member of the European Second Language Association. She also served as a Board member of the American International School of Budapest as well as Stockholm International School and as a chair/member of various Croatian and international educational committees and research projects. In April 2016 she was elected a Board member of the Educational Collaborative for International Schools, a global association for the promotion of international education.

In 2013 she started working as Director of Stockholm International School and in 2018 as Head of the Western Academy of Beijing. Since 2018 she has been cooperating with the Beijing University Graduate School of Education in training Chinese educators in international school curriculum and educational leadership.

Dr. Medved Krajnović has been invited as a keynote to Asian research and professional conferences. Her speeches focus on the complex ecosystems of 21 st century education, which puts emphasis on a holistic approach, student autonomy, agency, inclusion and the role technology plays in new approaches to education. 


\begin{abstract}
Nowadays, when globalization is having a strong influence across all spheres of life, people are aware of the significance of (foreign) languages. Since languages are influenced by the surrounding environment and are therefore constantly developing, fast changes in technology have influenced second language acquisition and interaction between students, students and teachers and students and computers at higher education institutions. In line with the need for a better understanding of influences that technology has on language learning at this particular level, research was conducted to investigate the role of blended learning in vocabulary acquisition and learner autonomy development in the context of English for specific purposes. The study included 179 participants, first-year students of University North, allocated to two groups (a face-to-face group and a blended learning group) in accordance with the level of their English language knowledge. Three hypotheses were formulated and in order to test them, both groups were asked to complete several tasks during the semester.
\end{abstract}

In order to test the first hypothesis, Blended learning of ESP vocabulary has the same effect on vocabulary acquisition as face-to-face learning, at the beginning of the semester, the students were asked to do a vocabulary test related to their study programme. At the end of the semester, vocabulary levels of both groups were tested once more and compared. Results of the study indicated that it is possible to acquire vocabulary in a blended learning environment to the same extent as in a traditional face-to-face environment.

In order to test the second hypothesis, Blended learning raises students' awareness of the possibility of more autonomous and independent English language acquisition in relation to the traditional classroom learning, and the third hypothesis, The effect of blended learning on the acquisition of ESP vocabulary and the level of students' self-assessed competence is related to the students' skill of using a blended approach to learning, that is their technological skills and the use of the technology for learning purposes, the students were asked to fill in a questionnaire containing questions about their self-assessed technology competence, attitude towards learning in blended and online environments and using technology for academic purposes, and to self-assess their English language knowledge using "can-do" statements. The results showed that the students involved in online learning were aware of the possibilities that blended learning offered, and the 
possibility of developing learner autonomy through technology and distance learning, but were not aware of any improvements in their language skills.

The results, in spite of certain limitations, confirmed those obtained by previous research and contributed to the field of second language acquisition, and they can therefore be applied in theory and practice to tertiary contexts outside Croatia.

Keywords: blended learning; English for Specific Purposes (ESP); learner autonomy; Second Language Acquisition (SLA); interaction; vocabulary acquisition 


\section{SUMMARY (PROŠIRENI SAŽETAK)}

\section{Uvod}

Koliko jezika govoriš, toliko vrijediš izreka je koja na vrlo jednostavan način prikazuje važnost poznavanja stranih jezika u današnje vrijeme, u doba globalizacije u kojem je engleski jezik prepoznat kao lingua franca. Engleski je jezik nezaobilazan u mnogim sferama života i oblicima komunikacije te je njegova uloga gotovo nezamjenjiva u komunikaciji putem računala i novijih digitalnih tehnologija. Iz tog se razloga tehnologija uključuje izravno u nastavu već na osnovnoškolskoj razini dok je na visokoškolskoj razini prisutna već duže vrijeme.

Na mnogim se visokoškolskim ustanovama u Hrvatskoj u sklopu redovitoga izravnoga poučavanja u razredu koriste različiti sustavi otvorenoga koda (na primjer Moodle) najčešće kao dodatni alat za učenje. Iako digitalne tehnologije imaju znatan potencijal u poučavanju (Dahlstrom, Walker, i Dziuban, 2013), na području stranoga jezika prema Mikulan, Legac i Oreški (2017) nastavnici koji poučavaju strani jezik u Hrvatskoj manje se koriste takvom tehnologijom i alatima unatoč toga što su alati korišteni u nastavi usklađeni s mogućnostima i sposobnostima studenata koji odrastaju u digitaliziranome svijetu te su se njima spremni služiti. Uvođenjem novih tehnologija i učenja na daljinu u poučavanje stranoga jezika studentima se može pružiti podrška prilikom učenja uz njihovu smanjenu fizičku prisutnost na nastavi. Na taj bi im se način omogućila veća razina kontrole nad pojedinim aspektima učenja (Benson, Grabe i Stoller, 2001), što je posebno važno za studente koji studiraju uz rad (izvanredni studij). U Hrvatskoj je taj proces tek donekle zaživio u punom obliku te postoji manji broj istraživanja koja bi ponudila znanstveno utemeljene spoznaje potrebne za oblikovanje sustavnoga pristupa učenju i poučavanju stranoga jezika struke na visokoškolskoj razini. Na tragu rezultata istraživanja koje je Fučkan Držić (2009) provela o učenju engleskoga kao jezika struke uz podršku programskoga sustava za e-učenje i danas se potvrđuje da integraciju informacijske i komunikacijske tehnologije i stranih jezika u hrvatskome obrazovnome kontekstu vrijedi istraživati kako bi se iskoristile njezine prednosti. Pritom je suradnja između znanstvenika i nastavnika nužna jer postoji zajednički cilj: utvrditi kako se ovladava inim jezikom $\mathrm{u}$ različitim uvjetima te kako se znanstvene spoznaje o tome procesu mogu primijeniti u praksi (Ellis, 2010). 
Nagrađeni projekt Engwiki (Kovačić, Bubaš i Zlatović, 2007) jedan je od pozitivnih primjera kako se računalno potpomognuto učenje jezika ili RPUJ (eng. Computer Assisted Language Learning) može primijeniti u visokoškolskim ustanovama i to kao primjer raznovrsnosti uporabe tehnologija za učenje jezika. Autori projekta došli su do zaključka da korištenje wikija u poučavanju engleskoga kao jezika struke, ali i kao inoga jezika općenito, može imati pozitivne učinke poput obogaćivanja okruženja za učenje i doprinosa usvajanju vokabulara. Pritom je ključno kvalitetno planiranje i priprema, nadgledanje i usmjeravanje studenata prilikom rada što podrazumijeva $\mathrm{i}$ prikladno obrazovanje nastavnika (Kovačić, Bubaš i Zlatović, 2007; Ernest i sur., 2012; Hampel i Stickler, 2015).

Korištenje različitih alata za računalno posredovanu komunikaciju ili RPK (eng. ComputerMediated Communication) i platforma za e-učenje poput Moodlea pripada tzv. integrativnom pristupu računalno potpomognutom učenju jezika (Warschauer, 2004), koji se temelji na računalima i internetu kao hipermedijskim izvorima kojima se može pristupiti s osobnoga računala. Fučkan Držić (2009), Fučkan Držić i sur. (2011) naglašavaju zamjetne mogućnosti za usvajanje vokabulara pomoću multimedija, kao i izgradnju pozitivnih stavova studenata prema računalno potpomognutome učenju stranoga jezika. U svrhu uočavanja navedenih mogućnosti i pozitivnih stavova na visokoškolskoj razini usmjereno je istraživanje predstavljeno u ovoj doktorskoj disertaciji.

Prema Schmitt, Schmitt i Clapham (2001) veličina govornikova vokabulara izravno je vezana uz njegovu sposobnost služenja jezikom na različite načine. To treba posebno uzeti u obzir u učenju engleskoga jezika na visokoškolskim ustanovama tehničkoga usmjerenja, odnosno ovladavanju vokabularom engleskoga kao stranoga jezika struke (Chung i Nation, 2004). Poznavanje struke omogućuje studentima vladanje engleskim jezikom u kontekstu koji je njima važan i koji jezik s kojim se susreću čini smislenim i proširuje sadržaj kolegija i izvan učionice (Crawford, 2002). Tako se u ovome istraživanju ispituje okružje učenja engleskoga kao stranoga jezika struke uzimajući pritom u obzir i društvene izvore individualne varijabilnosti koji su istaknuti čimbenici ovladavanja inim jezikom (v. Ortega, 2011). Istraživanje se na primjeru dviju grupa, a time i dvaju pristupa učenju, usredotočilo na procese jezičnoga unosa (engl. input), prihvata (engl. intake) i ostvaraja (engl. output) koji se realiziraju u dva različita okruženja na temelju ideje da je pretvorba 
unosa u prihvat ključna za razumijevanje usvajanja inoga jezika (Truscott i Sharwood Smith, 2011). Slijedom toga, važno je da nastavnik prezentira jezične strukture (na primjer vokabular) u obliku unosa koji je po svom sadržaju značajan za učenika (vokabular struke kroz autentične tekstove) kako bi se kroz prihvat (vokabular koji je učenik zapamtio) pretvorio u ostvaraj (vokabular u obliku rječnika ili wikija), pri čemu je u ovoj disertaciji ostvaraj u fokusu analiziranja.

Teorije usvajanja inoga jezika, posebice teorije unosa i međudjelovanja, tj. interakcije (Long, 1983; Krashen, 1982; Gass, MacKey i Pica, 1998), pružile su konceptualni okvir za ovo istraživanje. Teorija unosa i međudjelovanja usredotočuje se na proces služenja jezičnim unosom tijekom ovladavanja inim jezikom i njegove učinkovite uporabe. Učenici se razlikuju prema brzini usvajanja inoga jezika, procesu učenja i jezičnoga ostvaraja (Ellis, 1994; Cook, 2003; Ortega, 2011). To je osobito uočljivo na visokoškolskoj razini kada se njihovi ciljevi učenja i ponašanje često razlikuju i zbog načina studiranja (ili studiraju kao redoviti studenti ili istodobno studiraju i rade). Nastavnici bi trebali prilagoditi svoje poučavanje potrebama studenata kako bi se olakšalo njihovo ovladavanje jezikom. Ključno je osigurati da se učenik učinkovito služi znanjem o svijetu kako bi jezični unos učinio razumljivim (Krashen, 1982; Long, 1983; Ellis, 1991) te kako bi mu se, kao što ističe Swain (2000), pomoglo da osvještavanjem praznina u svome jezičnome znanju promijeni svoj jezični ostvaraj.

S obzirom na individualne razlike studenata tijekom procesa učenja jezika (poput ranije navedene brzine usvajanja inoga jezika ili samog procesa učenja), potrebno je osim razine poznavanja stranoga jezika odrediti i razinu njihove tehnološke pismenosti. Na tim se temeljima studentima pruža adekvatna potpora kroz promjenu njihova okruženja za učenje jer se ista aktivnost može ostvariti različitim radnjama i oblicima posredovanja (Lantolf, 2000). Upravo se modernim tehnologijama može omogućiti učinkovita promjena toga okruženja spajanjem izravnoga i računalnoga učenja. Takvo hibridno učenje koje je u literaturi najčešće definirano kao spoj tradicionalnog izravnog poučavanja i e-učenja (Graham, 2013) dobiva na značaju sve češćom uporabom interaktivne računalne tehnologije.

Unatoč prepoznavanju mogućnosti i praktičnosti računalnoga učenja i učenja na daljinu, važno je istaknuti da rezultati novijih istraživanja koji su opisani u disertaciji upozoravaju na niz izazova 
koje donosi nedostatak izravne komunikacije pa se naglašava da je u okruženju učenja na daljinu uloga nastavnika u promicanju interaktivne komunikacije nezamjenjiva. Ovo se istraživanje, stoga, usredotočilo i na učenikove potrebe za izravnom komunikacijom i podrškom nastavnika.

Budući da nastava postaje sve više usredotočena na učenika (Hampel, 2009), u istraživanju je naglasak stavljen na računalno posredovanu komunikaciju na visokoškolskoj razini između studenata te između studenata i nastavnika. Tako se studentima mogu predstaviti različiti zadaci i aktivnosti koje zahtijevaju njihov angažman u različitim načinima rada. Oni postaju samostalniji i neovisniji prilikom učenja u hibridnome okruženju te tehnologiju koriste sukladno svojim ciljevima. Na taj način preuzimaju kontrolu nad svrhom i načinima na koje uče jezike, odnosno aktivno se uključuju u proces učenja preuzimajući kontrolu nad čimbenicima kao što su vrijeme, učestalost, tempo, okruženje, pri čemu ujedno postaju kritički svjesni ciljeva i svrhe učenja (Little, 1991; Benson, 2013). Dok se istraživanje jednim dijelom usredotočuje na značaj koji samostalnost u učenju ima za učenika tijekom hibridnog učenja inoga jezika, a što je vidljivo kroz njihovu angažiranost na zadacima, drugim se dijelom usredotočuje na usvajanje vokabulara potpomognuto hibridnim učenjem.

\section{Ciljevi i hipoteze}

Glavni je cilj istraživanja bio omogućiti detaljniji uvid u učinak koji hibridni model učenja ima u usporedbi s tradicionalnim pristupom na usvajanje stručnoga vokabulara kod studenata engleskoga kao stranoga jezika struke. Usmjeravanjem fokusa na značaj koji u tom procesu usvajanja ima hibridni model učenja za pretvaraj jezičnog unosa u prihvat (kako se nove jezične informacije mogu uočiti njihovom primjenom u novoj jezičnoj situaciji) te ostvaraj mjerljiv u obliku konkretno odrađene aktivnosti (wikiji i glosar) pružaju se korisne informacije za to područje istraživanja u Hrvatskoj. Očekivana je i spoznaja o tome kako hibridno učenje doprinosi osvještavanju ovladavanja inim jezikom, posebno u odnosu na samostalnost u učenju, a time omogućivanju usvajanja inojezičnog vokabulara jednako uspješno kao i u razrednomu učenju. Time se doprinosi i spoznaji o usvajanju vokabulara $\mathrm{u}$ inomu jeziku općenito. $\mathrm{K}$ tome, istraživanjem usvajanja $\mathrm{u}$ hibridnom okruženju i njegovom usporedbom s izravnim učenjem u razredu propitkuje se uloga koju tehnologije i učenje u virtualnom okruženju imaju na usvajanje jezika. Uz to, promatra se i interakcija između učenika i nastavnika koja postaje interakcija između učenika i učenika, ali i 
učenika i računala, pri čemu nastavnik preuzima ulogu pratitelja samog procesa. Rezultati ovoga istraživanja mogli bi se upotrijebiti i u nastavi, posebno sa studentima koji studiraju uz rad.

Na temelju navedenoga postavljeno je nekoliko istraživačkih problema i hipoteza.

Ovo istraživanje pokušava utvrditi može li se primjenom hibridnoga učenja na visokoškolskoj razini poticati usvajanje vokabulara stranog jezika kod studenata različitih studija jednako uspješno kao i klasičnim razrednim učenjem. Postavljena je sljedeća hipoteza:

1) Hibridno učenje engleskoga stručnoga vokabulara ima jednak učinak na ovladavanje vokabularom kao i izravno učenje.

Ovim se istraživanjem ispituje utjecaj hibridnog učenja na osviještenost studenata o mogućnosti samostalnijeg ovladavanja engleskim jezikom u usporedbi s tradicionalnim razrednim učenjem. Iz toga slijedi hipoteza:

2) Hibridno učenje podiže razinu osviještenosti studenata o mogućnosti samostalnijeg ovladavanja engleskim jezikom u odnosu na tradicionalno razredno učenje.

Naposljetku, ovim se istraživanjem ispituje postoji li povezanost utjecaja hibridnoga učenja na usvajanje engleskoga stručnoga vokabulara i studentsku samoprocjenu jezične kompetencije s vještinom korištenja hibridnoga pristupa učenju, odnosno tehnološkim vještinama i korištenjem tehnologije u svrhu učenja. Hipoteza je sljedeća:

3) Učinak hibridnoga učenja na usvajanje engleskoga stručnoga vokabulara i studentsku samoprocjenu jezične kompetencije povezan je s vještinom korištenja hibridnoga pristupa učenju, odnosno tehnološkim vještinama i korištenjem tehnologije u svrhu učenja.

\section{Metodologija}

U istraživanju tijekom ljetnog semestra ak. god. 2014./2015. je sudjelovalo 179 ispitanika. Svi su ispitanici bili upoznati s ciljem istraživanja te da će se rezultati koristiti isključivo u istraživačke svrhe. Sudjelovanje u istraživanju je bilo dobrovoljno. Ispitanici su bili studenti prve godine na Sveučilištu Sjever (bivše Veleučilište u Varaždinu) upisani na pet različitih studija (Multimedija, oblikovanje i primjena, Tehnička i gospodarska logistika, Proizvodno strojarstvo, Elektrotehnika, 
Graditeljstvo) i na kolegij Engleski jezik u drugome semestru studija. Kolegij uključuje jezične i izvanjezične sadržaje koji su vezani uz opće i posebne svrhe, odnosno uz pojedinu struku. Studenti su podijeljeni u dvije grupe: 'izravno učenje' i 'hibridno učenje'. Obje grupe uključivale su sudionike približno iste dobi, prethodnoga obrazovanja (uglavnom tehničke škole) te slične izloženosti engleskome jeziku unutar formalnoga i neformalnoga okruženja.

U skladu s nastavnim planom i programom za kolegij Engleski jezik na Sveučilištu Sjever za potrebe predloženoga istraživanja prikupljeni su odgovarajući nastavni materijali prilagođavanjem odabranih materijala dostupnih u tiskanome obliku ili na internetu. Uz prikupljeni materijal oblikovane su odgovarajuće nastavne aktivnosti i zadaci.

Tijekom semestra ispitanici u grupi 'izravno učenje' redovito su polazili nastavu kolegija Engleski jezik i učili na uobičajen način. Studenti u grupi 'hibridno učenje' nisu imali obvezu sudjelovanja na nastavi u punoj mjeri, već su dobivali zadatke na platformi Moodle koji su sadržajno pokrivali tematiku koja se obrađuje na nastavi usporedno s dodatnim interaktivnim aktivnostima dostupnim na Moodle-u (wikiji i rječnik). Ti su studenti morali biti fizički prisutni na $20 \%$ nastave dok su preostalih $80 \%$ odradili računalno.

U istraživanju je korišten mješoviti metodološki pristup (engl. mixed methods approach): prikupljeni su i kvalitativni i kvantitativni podaci kako bi se stekle što dublje spoznaje o učinku usvajanja engleskoga vokabulara na visokoškolskoj razini hibridnim učenjem. Kvalitativni podaci omogućili su uvid u studentsko poimanje vlastitoga iskustva s upotrebom modernih tehnologija za učenje engleskoga jezika. Kvantitativni podaci poslužili su za usporedbu napretka studenata u usvajanju vokabulara u hibridnome okruženju s tradicionalnim izravnim učenjem.

Za potrebe procjenjivanja opće jezične kompetencije na početku semestra koja je poslužila kao temelj za razvrstavanje ispitanika $u$ ranije spomenute dvije grupe primijenjen je test za određivanje razine poznavanja engleskog jezika dostupan na internetu. Test se sastojao od pitanja koja procjenjuju gramatiku i vokabular. Odabran je zbog svoje jednostavnosti i povratne informacije o rezultatu koja je dostupna odmah po rješavanju, a studenti su ga mogli riješiti iz udobnosti svog doma u samo desetak minuta. Rezultate su elektroničkom poštom poslali nastavnici koja ih je na 
temelju njihove razine poznavanja jezika svrstala u dvije grupe tako da je u svakoj grupi bio otprilike jednak broj studenata iste razine poznavanja jezika.

Za potrebe procjenjivanja čestotne razine vokabulara na početku i na kraju semestra poslužio je Vocabulary Levels Test (Laufer i Nation, 1999), dostupan na internetu. Taj test mjeri veličinu vokabulara (Nation i Beglar, 2007), a poslužio je i kao potvrda da studenti posjeduju potrebnu razinu poznavanja jezika kako bi uspješno pratili nastavu.

Na početku i na kraju semestra primijenjen je i test oblikovan posebno za potrebe kolegija Engleski jezik i istraživanja, a uključuje obrađene jezične sadržaje u kojima je stavljen fokus na vokabular uz nekoliko vrsta zadataka (popunjavanje praznina, izjave točno/netočno i prijevod) s razlikama u vokabularu ovisno o studiju.

Podatci prikupljeni opisanim testovima vokabulara detaljno su analizirani, a rezultati su obrađeni grupno i uspoređeni s obzirom na vrstu učenja (izravno i hibridno) te na početku i na kraju provedenog istraživanja za grupu 'hibridno učenje'. Komparativnom analizom izvedeni su zaključci vezani uz hipotezu o usvajanju vokabulara hibridnim i izravnim učenjem koji su pomogli utvrditi može li se primjenom hibridnoga učenja na visokoškolskoj razini poticati usvajanje vokabulara stranog jezika kod studenata različitih studija jednako uspješno kao i klasičnim učenjem u razredu.

U svrhu provjere druge i treće hipoteze studenti su u upitniku odgovorili na pitanja o samoprocjeni tehnološke kompetencije, stavu prema učenju u hibridnom i online okruženju te korištenju tehnologije u akademske svrhe. Uz navedeno su izvršili samoprocjenu poznavanja engleskog jezika uz pomoć Europskoj jezičnog protfolija na početku i na kraju semestra i to komponentu jezične biografije, što je pružilo refleksivni dodatak procesu učenja i uporabe inoga jezika. Studenti su ocijenili svoja osobna jezična postignuća koja su im ujedno trebala omogućiti da promisle o vrijednostima svojih aktivnosti učenja (vidi Benson i sur., 2001) i tako pružiti korisne podatke o njihovoj samostalnosti u učenju. Prikupljeni podatci analizirani su pomoću programa za statističku obradu podataka jezika $\mathrm{R}$ i uspoređeni s obzirom na razlike u samoopažanju njihovih vještina. Tim su podatcima pridružene analize aktivnosti studenata tijekom izrade zadataka što je pomoglo donošenju zaključaka. 
Za prikupljanje podataka o tehnološkim vještinama ispitanika, njihovu stavu prema služenju tehnologijama za učenje jezika, korištenju platformom Moodle te općenitomu stavu prema učenju u novijem, digitalnom okruženju poslužio je upitnik. Upitnik je bio anoniman, ali je svaki student tijekom istraživanja uvijek upisivao istu šifru tako da se mogla ispitati povezanost samoprocjene i usvajanja vokabulara, ali i samostalnosti u učenju. Navedeni se upitnik temelji na instrumentu koji je osmislio Spitzberg (2006; 2011), ali je prilagođen potrebama ovoga istraživanja. Upitnik je predtestiran na hrvatskim ispitanicima. Studenti koji uče u tradicionalnom okruženju upitnik su ispunili jednom, a oni u hibridnome okruženju dva puta. Pritom je druga inačica sadržavala modificirana pitanja vezana uz iskustvo s novim načinom učenja engleskoga jezika kako bi se stekao uvid u samoprocjenu tehnoloških vještina ispitanika nakon hibridnoga učenja. Na temelju dobivenih podataka uspoređeni su rezultati pojedinih studenata s njihovim iskustvom u korištenju modernih tehnologija i učenju engleskoga jezika na daljinu. Podatci su analizirani pomoću programa za statističku obradu podataka jezika R primjenom odgovarajućih metrika. Analizom dobivenih podataka provjerena je hipoteza o povezanosti studentskih vještina u služenju modernim tehnologijama i učinku hibridnoga pristupa učenju engleskoga jezika na usvajanje engleskoga stručnoga vokabulara i studentsku samoprocjenu jezične kompetencije.

Preostala pitanja iz upitnika poslužila su kao način dobivanja dodatnih informacija o uporabi alata RPK u različite svrhe te su dobiveni podaci pripomogli donošenju zaključaka vezanih uz navike i preferencije studenata tijekom učenja u hibridnom, online i tradicionalnom razrednom okruženju i komunikaciji s kolegama i nastavnikom.

\section{Rezultati i diskusija}

Istraživanje je na temelju rezultata od kojih će najvažniji biti predstavljeni i obrazloženi u sljedećim odlomcima pružilo koristan uvid u područja hibridnog učenja, usvajanja vokabulara i razvoju samostalnosti učenja u kontekstu engleskoga kao stranoga jezika struke.

U svrhu potvrđivanja prve hipoteze da se primjenom hibridnoga učenja na visokoškolskoj razini može poticati usvajanje vokabulara stranog jezika kod studenata različitih studija jednako uspješno kao i klasičnim učenjem u razredu korišten je Vocabulary Levels test te test za mjerenje vokabulara na početku i na kraju semestra. Komparativnom analizom prikupljenih podataka utvrđeno je da se 
navedena hipoteza može potvrditi, odnosno da se vokabular može u jednakoj mjeri usvojiti hibridnim učenjem kao i tradicionalnim učenjem u razredu. Uz to, učenje u hibridnom okruženju pružilo je studentima mogućnost korištenja različitih oblika interakcije s nastavnicom, kolegama, ali i računalom, što je posebno vidljivo u ostvaraju u obliku glosara.

Što se tiče rezultata korištenja i izrade wikija i glosara kao aktivnosti koje je zadala nastavnica, oni su ukazali na nekoliko stvari. Prvenstveno, aktivnost studenata je bila zadovoljavajuća i većina je sudjelovala u njihovoj izradi, a razlikovala se na razini studija i na individualnoj razini. Njihov se ostvaraj u obliku rječnika i korisnih informacija o pojedinim strukama može smatrati korisnim materijalom za učenje. Iako se studente poticalo da pregledavaju i uređuju unose svojih kolega, nisu zadirali u tuđi sadržaj. Izradom wikija i glosara studente se poticalo na pretraživanje dostupnih materijala vezanih uz struku tako da su bili izloženi većem obimu unosa, što je na kraju i utjecalo na njihov završni rezultat na testu kojim se provjeravala usvojenost vokabulara. Uz to, sve riječi koje su bile u testu našle su se i u glosaru, što ukazuje na pozitivan utjecaj korištenja glosara u učenju jezika uz pomoć hibridnog učenja.

Nadalje, u svrhu potvrđivanja druge hipoteze prema kojoj se navodi da studenti koji uče $u$ hibridnom okruženju postaju svjesniji mogućnosti samostalnijeg ovladavanja engleskim jezikom analizirani su podaci prikupljeni uz pomoć samoprocijenjenih vrijednosti u Europskom jezičnom portfoliju na početku i na kraju semestra za studente u grupi hibridnog učenja te uz pomoć upitnika. Iako je manji broj studenata odradio samoprocjenu u obje točke mjerenja te se slijedom toga ne mogu izvući statistički zapaženi rezultati, pojedini odgovori iz upitnika kojeg su studenti ispunjavali na početku i na kraju semestra pružili su uvid u osviještenost studenata u pogledu mogućnosti samostalnijeg ovladavanja engleskim jezikom u hibridnom okruženju. Iz tih odgovora, ali i njihove aktivnosti tijekom ispunjavanja zadataka (wikija i glosara) možemo zaključiti da su svjesni mogućnosti koje hibridno okruženje pruža za razvoj samostalnosti te da im je važno učiti vlastitim tempom. S obzirom da je posljednji dio upitnika sadržavao dodatnih šest pitanja $\mathrm{u}$ završnoj fazi testiranja, polučio je korisne informacije vezano uz iskustvo učenja u online okruženju. Studentima je nedostajao izravni kontakt s nastavnikom, što govori u prilog hibridnom učenju koje omogućuje rad i izvan i unutar učionice. Izravna interakcija s nastavnikom, prema njihovom mišljenju, omogućuje kvalitetniju povratnu informaciju. Međutim, iako je većina 
studenata uvjerena da se samostalnost u učenju može razviti učenjem na daljinu jer sami diktiraju tempo učenja, rezultati i njihova aktivnost tijekom semestra ukazuju da oni još nisu spremni na potpunu samostalnost. Razlozi za to mogu biti nedostatak volje, nepoznavanje adekvatnih strategija učenja ili nedovoljan izazov tijekom izrade zadataka što je detaljno pojašnjeno u disertaciji.

Dodatna pitanja u upitniku omogućila su i uvid u računalne alate koje studenti koriste $u$ komunikaciji i njihova uporaba je u korelaciji s ugodom prilikom njihova korištenja. U svrhu komunikacije u akademskom okruženju najčešće koriste prijenosna računala te ih percipiraju kao najvažniji alat što je u skladu s literaturom. Ujedno im je važno da i nastavnik koristi najnovije tehnologije u nastavi, što prema njihovom mišljenju, podiže razinu poučavanja. Podatak da nakon iskustva $\mathrm{s}$ hibridnim učenjem studenti percipiraju pozitivnijim učenje u takvom okruženju $u$ usporedbi s tradicionalnim učenjem pridonosi saznanjima na području poučavanja jezika u hibridnom okruženju i izravno se može povezati s važnošću interakcije i konteksta - interakcija ostvarena korištenjem računalnih alata vodi $\mathrm{k}$ drukčijoj percepciji konteksta u kojem se ostvaruje učenje. Međutim, korištenje tehnologije u nastavi nema značajan utjecaj na percepciju zanimljivosti kolegija.

Sudionici su kroz odgovore u upitniku iskazali vrlo pozitivan stav prema korištenju tehnologije. Svoju su opću računalnu kompetenciju procijenili na temelju nekoliko konstrukata: njihova motivacija i efikasnost, za razliku od samoprocjene razine znanja, produktivnosti i općeg iskustva s računalima, nisu porasle od faze testiranja na početku do one na kraju semestra, što potvrđuje pretpostavke i rezultate u literaturi. Navedeni rezultati na temelju prikupljenih podataka iz prvog dijela upitnika poslužili su za testiranje treće hipoteze. Kompetencije RPK iz početne i završne faze testiranja uspoređene su s rezultatima testa koji je provjeravao usvojenost vokabulara. Na temelju dobivenih i analiziranih rezultata može se ustvrditi da ne postoji dokaz o povezanosti tehnoloških kompetencija i rezultata stručnog vokabulara na kraju semestra.

Slijedom svega navedenog može se zaključiti da su studenti spremni koristiti tehnologiju i različite oblike komunikacije koje ona nudi u svrhu učenja te rezultati potvrđuju vrijednost njezina korištenja u nastavi engleskog jezika. Jedan od tih oblika je Moodle kojeg su studenti koristili u hibridnom okruženju tijekom praćenja nastave pa su trebali procijeniti svoje znanje i vještine te 
izraziti stavove vezane uz korištenje Moodle-a. Analiza rezultata pokazala je da je stav studenata prema korištenju Moodle-a u nastavi izrazito pozitivan, da su studenti zadovoljni svojim znanjem i vještinama te da Moodle koriste najčešće za prikupljanje informacija o kolegiju. Iako je u završnoj etapi istraživanja wikije koristilo više studenata nego u početnoj, jasno je vidljiv podatak da nisu svi studenti surađivali u njihovoj izradi. Navedeno govori o njihovoj spremnosti da preuzmu odgovornost za svoje učenje.

Studenti koji su učili u hibridnom okruženju bili su svjesni mogućnosti koje im takvo okruženje pruža korištenjem Moodle-a, ali su bili spremni koristiti samo one alate čije je korištenje predvidjela i zadala nastavnica. Iako studenti nisu bili svjesni svog napredovanja na jezičnoj razini, bili su svjesni da na taj način, uz pomoć tehnologije i učenja na daljinu imaju mogućnost razvijati svoju samostalnost u učenju. Osim toga, učenjem u hibridnom okruženju imaju mogućnost koristiti različite oblike interakcije s ostalim studentima i putem računala koliko je to god puta potrebno te tako imaju vremena za postizanjem samoregulacije. Tek kad toga postanu svjesni, mogu raditi na razvijanju svoje samostalnosti.

Rezultati dijela upitnika koji se odnose na učenje na daljinu, koji su trebali pružiti uvid u stav studenata prema online okruženju kao okruženju u koje se može uvrstiti i hibridno okruženje, ukazali su na pozitivne stavove studenata prema učenju na daljinu i spremnost na praćenje kolegija na mreži, iako su svjesni da učenje na u online okruženju predstavlja određene izazove i zahtjeva visoku razinu samodiscipline. Uz to, smatraju da se učenjem na daljinu može najbolje razviti vještina pisanja, a govor najmanje. Slijedom toga, nastavnici bi trebali raditi na razvijanju svih vještina prilikom učenja na daljinu.

\section{Zaključak}

Glavni je cilj ovog istraživanja bio odrediti kakvu ulogu ima hibridno učenje u usvajanju vokabulara i razvoju samostalnosti u učenju kod studenata u kontekstu stranog jezika struke. Svojim rezultatima ovo istraživanje doprinosi saznanjima u navedenim područjima, daje uvid u proces razvoja jezičnog unosa u prihvat te kako se nove jezične informacije zamjećuju upotrebom u novoj jezičnoj situaciji kroz wikije i glosar i pretvaraju se u ostvaraj. Uz to, rezultati imaju i 
praktičan doprinos usvajanju stranog jezika struke u hibridnom okruženju i razvijanju samostalnosti u učenju.

Ključne riječi: engleski kao jezik struke; hibridno učenje; interakcija; proces ovladavanja inim jezikom; samostalnost u učenju; usvajanje vokabulara 
Table of Contents

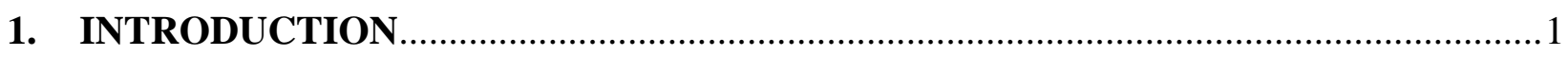

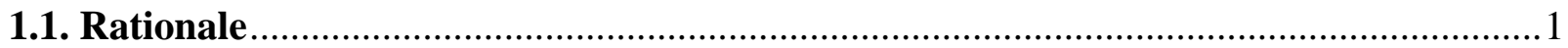

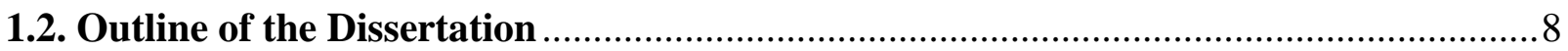

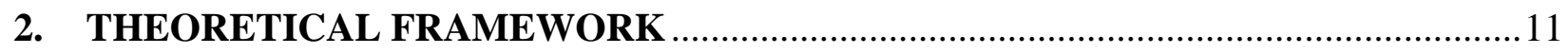

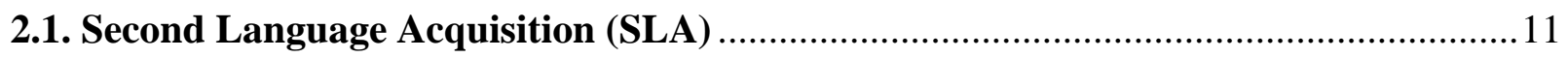

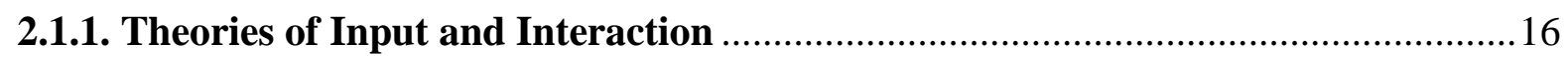

2.2. English for Specific Purposes (ESP) Context .......................................................2 27

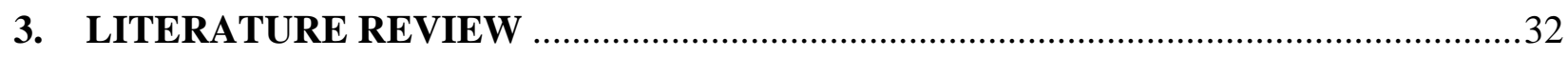

3.1. Information and Communication Technology in Education and Language Learning

3.2. Computer Assisted Language Learning (CALL) and Computer-Mediated

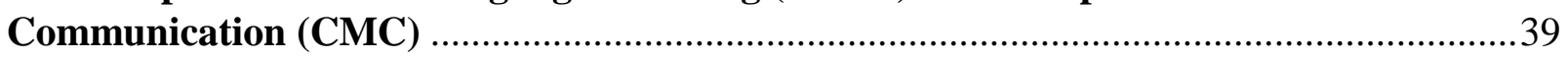

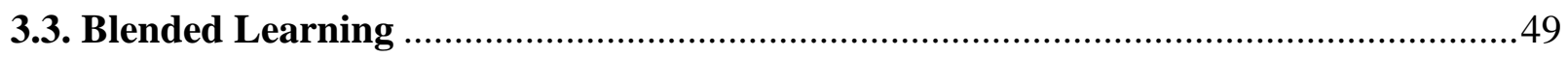

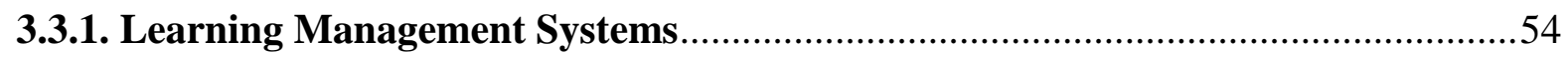

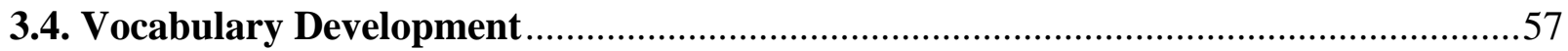

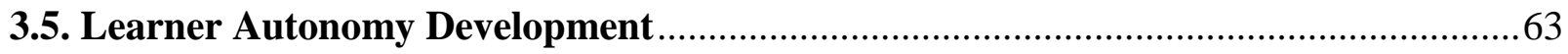

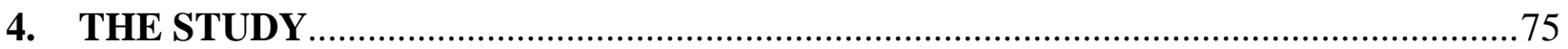

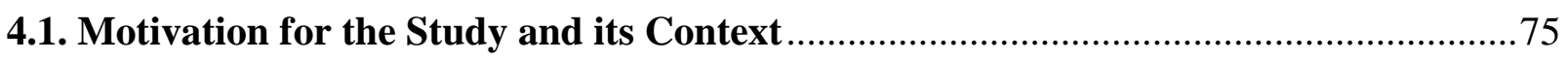

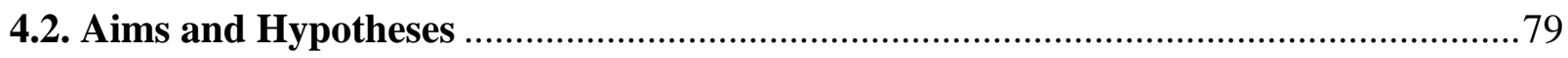

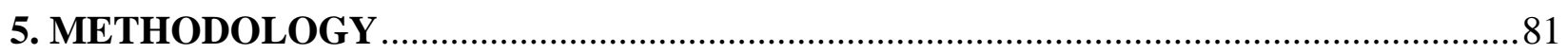

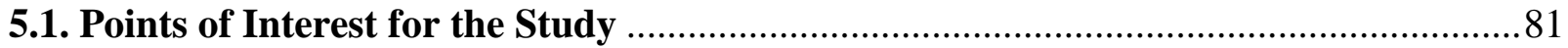

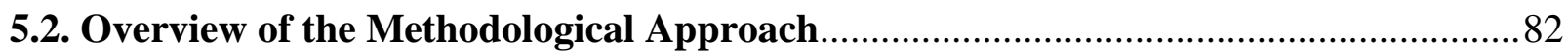

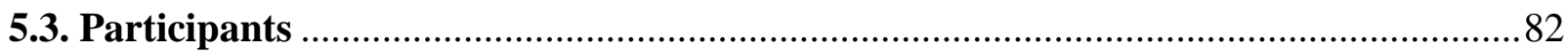

5.4. Blended and Face-to-Face Learning and its Influence on Vocabulary Acquisition and

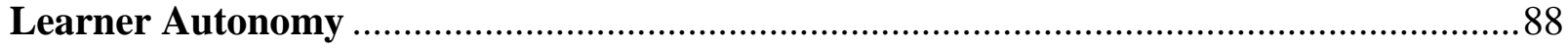

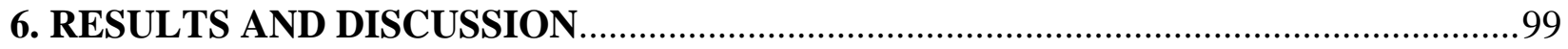

6.1. Learning Environment and Vocabulary Acquisition ......................................... 100

6.2. Vocabulary Acquisition and Learner Autonomy …............................................ 103

6.3. Blended Learning and Autonomous Learning .................................................. 113 
6.4. Blended Learning and Students' CMC Competences and Professional Vocabulary Acquisition

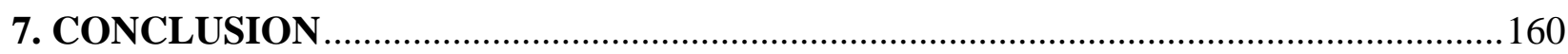

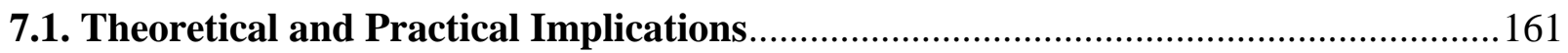

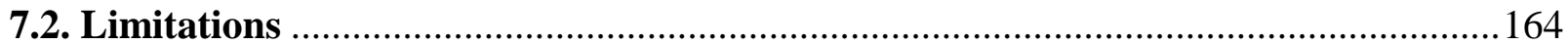

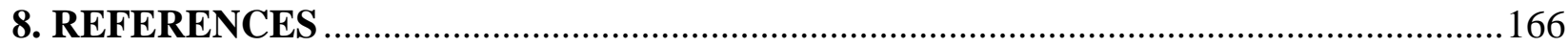

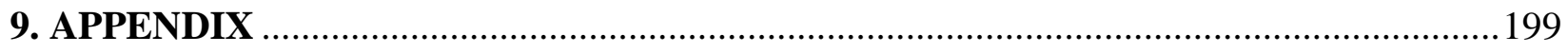

APPENDIX A: An example question from the 'Check your Level' test ......................... 199

APPENDIX B: A result of the 'Check your Level' test ................................................200

APPENDIX C: Vocabulary Test - 1000 Level Test A ............................................201

APPENDIX D1: Vocabulary test (Electrical Engineering) .........................................204

APPENDIX D2: Vocabulary test (Mechanical Engineering) .......................................205

APPENDIX D3: Vocabulary test (Multimedia, Design and Application) ......................206

APPENDIX D4: Vocabulary test (Technical and Economic Logistics).........................207

APPENDIX D5: Vocabulary test (Civil Engineering)...........................................208

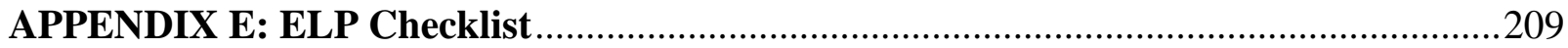

APPENDIX F1: Questionnaire (pre-testing stage) ................................................220

APPENDIX F2: Questionnaire (post-testing stage with additional questions)...............224 


\section{List of abbreviations}

$\mathrm{BL}$ - blended learning

CALL - Computer Assisted Language Learning

CMC - Computer Mediated Communication

ELP - European Language Portfolio

ESP - English for Specific Purposes

$\mathrm{FtF}$ - face to face

ICALL - Intelligent Computer Assisted Language Learning

ICT - Information and Communication Technology

L1 - first language

L2 - second language

LMS - Learning Management System

MMO - Massively Multiplayer Online

SLA - Second Language Acquisition 


\section{INTRODUCTION}

\subsection{Rationale}

'The more languages you speak, the more of a person you are'. This proverb, which is frequently used in Croatia, not only shows the significance of (foreign) languages but it also shows people's awareness of how important and useful it is to be able to learn (an)other language(s) besides one's mother tongue. That is one of the reasons foreign language acquisition has been studied from various points of view with different theoretical backgrounds. However, languages are subject to change and their acquisition is influenced by the surrounding environment, offering new possibilities for a researcher. Technology development constitutes one such change and its influence on foreign language acquisition, particularly in the area of vocabulary, is used as a starting point for a detailed study that will be presented in this dissertation.

The following sections of the chapter will discuss the connection between the concepts that are the focus of this dissertation (blended learning, vocabulary acquisition, learner autonomy, English for specific purposes) in order to provide the reader with a rationale for studying these concepts in their interdependence and importance for language learning.

The research focuses on the English language which has become a lingua franca of modern communication, whether in a face-to-face or online environment (Pietikäinen, 2017; Sangiamchit, 2017; Seidlhofer, 2005). In Croatia today, English is the most popular foreign language; however, such has not always been the case. As Prebeg Vilke, the pioneer of English language teaching research in Croatia, pointed out in 1977, German and French used to be the two main foreign languages taught at secondary level. Although teaching English as a foreign language started in 1882, it was not as frequent or regular. In her research related to teaching English as a foreign language, Prebeg Vilke emphasized the importance of learning foreign languages at an early age (Mihaljević Djigunović, 2010). The importance of her work was finally recognized in the 2002/03 school year with the introduction of a foreign language as an obligatory subject from the first grade of elementary school. More recently, since 2009/10, the foreign language exam is one of the three obligatory exams to be taken as part of the national Matura exam which students take to complete their secondary education. 
The importance of foreign languages, English in particular, can be seen as well at the tertiary level: at higher education institutions in the technical field it is usually obligatory to study a language course and at most universities students can choose between English and German. However, there has been a change in the level of uptake of these two languages, with English gaining importance over German; this was prevalent at University North, where most students chose English over German as their mandatory foreign language course. In the 2009/10 academic year there were 380 students learning German and 609 students learning English, while in 2013/14 the situation changed noticeably in favour of English with 133 students learning German and 396 learning English. When asked to explain their language choice at introductory English language lessons, the students' usual answers were that English is the language that everybody understands and that, unlike German, it is easier to learn and use; this is despite the fact that in the part of Croatia where the University is located, there is a greater chance that the companies the students might work for in future do business with companies from German speaking area. ${ }^{1}$

Another reason why students at tertiary education institutions choose English over German, besides their preference as expressed above, is the increased student (and teacher) mobility within Europe and beyond, which requires competence in general English and, depending on the purpose, the knowledge of English for specific purposes (ESP), which deals with specific topics related to the student's future profession.

In this study greater emphasis is placed on ESP than general English. In ESP the vocabulary to be acquired is the vocabulary related to a specific profession, or to be precise, the vocabulary in question is technical vocabulary. The main features of technical vocabulary are that it is subject related, occurs in a specialist domain, and is part of a system of subject knowledge (Chung \& Nation, 2004). According to Schmitt (2010), technical vocabulary is specific to a particular field and thus essential to understanding discourse in the field, which makes vocabulary acquisition central for ESP. The technical vocabulary contained in ESP is taught at tertiary level and is a

\footnotetext{
${ }^{1}$ Unfortunately, since the 2015/16 academic year, the only foreign language students can learn or continue learning is English. The reason for that, according to the university's management, is that students show more interest in learning English than German, and as the majority of students tend to choose English, there is no need to offer German.
} 
worthwhile subject to examine as it plays a crucial role in the professional success of many graduates who go on to work in English-speaking contexts. Hence one of the objectives of this study is to gain insight into vocabulary acquisition and the following part of the chapter will deal with the importance of vocabulary acquisition for language use in the specific ESP context of the research in more detail.

According to Schmitt, Schmitt, \& Clapham (2001), a speaker's vocabulary size is directly related to their ability to use English in various ways, such as basic everyday oral communication or reading authentic texts. This is then closely related to the purpose for which the language is used. For example, reading authentic texts is usually used as a method of learning a language at university level, especially in the context of ESP. The general purpose of ESP instruction is to help students become more proficient in their field of study depending on their individual needs (Dudley-Evans \& St. John, 1998). Here the teacher only supports the students regarding their language acquisition since the students are already (up to a certain point) experts in their main field of studies such as mechanical, civil or electrical engineering. Using the English language in a professional context that is important for the students makes the language encountered meaningful and extends the course content beyond the classroom (Crawford, 2002). This applies even more to part-time students - students who study and work at the same time - who are already quite familiar with their field of studies thanks to their personal working experience. Their need for using ESP in their working environment can be a powerful driving force for vocabulary acquisition in a particular area. Moreover, their knowledge of ESP can facilitate career advancements in a competitive working environment.

Given these considerations, vocabulary acquisition in ESP presents an important and interesting research topic. That being the case, this study examines tertiary students' vocabulary development within the framework of second language acquisition (SLA) theories of input and interaction (Long, 1983; Krashen, 1982; Gass, MacKey, \& Pica, 1998), while also referring to principles used in sociocultural theory. The aim of SLA research has been to describe and explain the process of acquiring a second language - with the term 'second' referring to any additional language besides the mother tongue (Cook, 2003:71). Learners differ in terms of rate of second language acquisition, 
learning processes and outcomes (Ellis, 1994; Cook, 2003; Ortega, 2011): for example, they vary regarding how much time is needed to acquire a certain linguistic element or aspect. This could be due to their individual differences - their motivation, for example, may play a role in the process of second language acquisition - or it could be due to how they are taught or how much exposure they have to the second language outside formal education. In addition, variation in terms of the outcomes that students are trying to achieve influences the choice of the processes they employ to learn a language. This is particularly noticeable at tertiary institutions attended by students whose learning goals and behaviour differ due to their study mode (i.e. study full time or part time).

In order to help students achieve their potential and facilitate language development, teachers should adapt their teaching to the individual needs of students. Input and interaction theory (Krashen, 1982; Long, 1983; Ellis, 1991), which serves as the background of this research, focuses on the process of using language input, and its efficient use, during second language acquisition. Input, the language that a learner may encounter in written or spoken form, is usually modified and simplified by the teacher so as to be comprehensible. When it is made comprehensible and it affects the development of a learner's linguistic knowledge, it is called intake (how new linguistic information can be noticed by its use in a new linguistic situation). The results of this process can be seen in the learner's linguistic production. Therefore, the teacher's task is to ensure that all students receive appropriate input in accordance with the desired output. As the notion that conversion of input to intake is central to an understanding of SLA (Truscott \& Sharwood Smith, 2011), one focus of this study is how language input-intake-output processes are realized in blended learning in an ESP context, with particular emphasis placed on output.

Within this theoretical framework of input and interaction, the focus of this study is also placed on using technology to achieve the desirable transfer from input to intake. The use of technology in various areas of life (for social and academic purposes) has been growing and thus developing. New technologies have become ubiquitous, and they permeate people's lives by facilitating their daily activities. One of the activities that can be facilitated by using technology is language learning. By introducing new technologies and distance learning into English language teaching, students can be supported in their learning without always having to be physically present at the 
lessons. This enables them being more autonomous - they can choose not only the setting for their learning, but they also have control over the pace of learning with regard to their learning goals and learning styles.

However, using technology in the classroom is not always easy for students or for teachers - it requires the skills of doing so in an appropriate way and it presupposes the motivation of the users. According to Mikulan, Legac, \& Oreški (2017), teachers in Croatia still do not use available technology and tools to their full potential. In contrast, students who have grown up in a digital world are more than ready to use these technologies and tools that also have great potential in educational settings (Brooks \& Pomerantz, 2017; Dahlstrom, Walker, \& Dziuban, 2013). The research described in this dissertation will focus on how the use of technology in the English language classroom can be supported, offering theoretical and practical evidence which should enable students to display a greater degree of control over particular aspects of their learning (Benson, Grabe, \& Stoller, 2001).

This control is particularly important for part-time students. In Croatia, part-time students are usually not treated differently in any way from full-time students. The learning outcomes of courses are the same and the number of lessons they have to attend is, in most cases, the same for both groups. They only differ regarding the fact that students in one group work alongside their studies and the other ones do not. However, part-time students sometimes have difficulties attending classes regularly because of their working hours which often overlap with their classes. This in many cases reduces the amount of input they receive. As a result, these students have to be highly self-motivated and institutions need to try to find ways in which to compensate for lost lessons. One of the ways this can be done is by using technology.

In order to understand the process of learning a second language using new technologies in various settings (tutored and untutored, full-time and part-time, using the computer as a tutor for individual students or as a tool for learner interaction) and how these findings can be applied to practice, cooperation between researchers and teachers regarding practical implementation of research is needed since they have a mutual goal (Ellis, 2010). Technology use for language learning or computer-assisted language learning or CALL (Chapelle, 2010:66) can be implemented in more 
than one way - one of the successful Croatian examples of how this can be done in a tertiary institution is the interactive award-winning project Engwiki (Kovačić, Bubaš, \& Zlatović, 2007). The authors found that the use of wikis in English language courses can have positive impacts such as enriching the learning environment and contributing to the learning of vocabulary. Using tools such as wikis or weblogs, can enhance effective instructional approaches if they are thoughtfully used as additional tools (Warschauer, 2010), for example, to support the development of student's academic language proficiency; however, quality planning and preparation of classes as well as monitoring and moderating of students' work are crucial, requiring the training of teachers (Ernest, et al., 2012; Hampel \& Stickler, 2015). If teachers learn how to use these tools effectively, learners can be aided in becoming more autonomous in their learning since these tools enable them being more independent with regard to their learning. The introduction of modern technologies into the classroom also means that learning does not have to be done solely face-to-face and social interaction needed for developing linguistic skills can be realized via particular technological tools, such as Skype or Messenger.

Fučkan Držić (2009) in her research on the use of information and communication technology (ICT) and how it can be applied to foreign language teaching at tertiary level pointed to the need to study it in more detail in the Croatian context. Her research provides some valuable findings on the usefulness of ICT in this specific context with emphasis placed on reading, writing, and motivation for individual research and team work through different forms of interaction. Similarly to her research, this study will try to gain insight into some of the possibilities that ICT has to offer to foreign language teaching by providing evidence that could be used in teaching practice, more generally in the context of vocabulary acquisition and learner autonomy, which has not been done in the Croatian context.

According to sociocultural theory (Vygotsky, 1978; Wertsch, 1991), the development of cognitive activity is mediated by social interaction, and language plays a major role in this. Lantolf (2000) maintains that the same activity can be realized through different actions and with different forms of mediation. In this way, by expanding their learning environment, students can be given additional support with the possibility of using different forms of interaction to help them scaffold 
their learning. This is where using modern technologies in conjunction with face-to-face learning could be of significant help to students. However, changing our environment also affects the way we function and learn.

The combination of traditional face-to-face learning (and teaching) and e-learning is generally defined as blended learning (Graham, 2013). Since blended learning is gaining importance because of the increased availability of interactive computer technology (Blake, 2011) and because it seems to address some of the challenges that distance learners face, this study will investigate its impact in the context of foreign language acquisition.

Studies conducted in the field of English language learning found that blended learning is a good way of supporting foreign language learning (Coryell \& Chlup, 2007; Arnó Macià, 2012). Using open source learning management systems, such as Blackboard, Moodle or Omega, as an additional tool for learning has become a regular part of teaching in many subjects at tertiary institutions in Croatia. Even though this process of introducing blended learning has existed at tertiary institutions in Croatia for some time now, there is a lack of research that would offer the scientific understanding needed to shape a systematic approach to learning and teaching of foreign languages for specific purposes at tertiary institutions that either combines face-to-face and online elements or is done completely online (Seljan, Banek, Špiranec, \& Lasić-Lazić, 2006).

However, language learning in blended settings presents many challenges. Even in distance settings the teacher's role in promoting interactive communication is irreplaceable, and so this study will also need to focus on the support requirements that learners have (see White, 2006). Since there has been a tendency to make teaching more learner-centred by using various teaching methods to increase interaction, the emphasis has been put on computer-mediated communication (CMC) which provides the much-needed interaction and collaboration between students and between students and teachers (Hampel, 2009). In this way students can be presented with various interactive tasks and activities which require their engagement in a variety of modes (ibid.), depending on their communication purpose - for example, whether they need to communicate actively (for example, by exchanging information by communicating in speaking or writing), or just interpret the message that is being communicated (for example, by following the teacher's 
lectures or read a passage of a text with the purpose of understanding its message). The participants at the centre for the research described in this dissertation need to interpret the message and understand specific vocabulary so as to produce language required in the professional context. How successful they are in accomplishing their communication purpose in a specific, blended environment depends also on how autonomous and independent they are. Therefore, another objective of this study will be to acquire understanding of the significance that learner autonomy has for learners in the blended learning environment, and the role of the teacher in the development of learner autonomy. This will be examined through the students' active involvement in their assignments while the teacher contributes to learner autonomy by preparing tasks that enhance learning in the blended learning environment, and by providing additional support.

It is expected that the study will show that blended learning has a positive impact on both vocabulary acquisition and learner autonomy. By using a mixed methods approach this quasiexperimental study will enable a deeper insight into the effect that the blended learning model in comparison with the traditional approach has on the acquisition of specific purposes vocabulary of students at tertiary level who study English related to their profession. The obtained results will provide an insight into the students' perception of, and their experience with, modern technologies used in learning English for specific purposes. In addition, this study will not only contribute to the field of research on vocabulary acquisition, but will also contribute to the examination of students' progress in a blended environment as compared to traditional face-to-face learning; this will also inform tertiary education practice by giving further insights into the process of blended language learning.

The rationale in this section has explain why the titled topic is worth investigating; the section that follows will outline the study and how it is presented in this dissertation.

\subsection{Outline of the Dissertation}

The thesis is set out as follows: After this introductory chapter, which gives the rationale and outlines the dissertation, Chapter 2 provides the theoretical framework with a general insight into the main theories and concepts referred to within the research. The first section discusses the central concepts that relate to the area of second language acquisition (SLA). It defines the term 'second 
language' used in the dissertation before continuing with a brief description of the interdisciplinary concept of SLA and the significance it has in formal language learning environments. This is done by reviewing the literature in the field, associating it directly with the study through discussion of the theories of input and interaction (see sub-section 2.1.1), and how they were used in the context of this study. It is additionally supported with interaction from a sociocultural perspective, which places the focus on interaction between a learner and a computer. The thesis continues with another section (2.2) that sets out this study in the context of English for Specific Purposes (ESP) and discusses how this approach can be used for the purposes of teaching and learning a second language at a tertiary institution. It describes the development of the study and the main constructs that will be used to show how this context relates to the concepts of blended learning, vocabulary development and learner autonomy that are described in the chapter that follows this one.

Chapter 3 reviews the literature related to the areas of the research that present key concepts of the dissertation scrutinized through the prism of second language acquisition. It begins with insights into Information and Communication Technology (ICT) and discusses its role in education and language learning (3.1). This is followed by a review of the literature exploring the use of new technology for language learning through the prism of Computer Assisted Language Learning (CALL) and Computer Mediated Communication (CMC) (3.2), and their association with Second Language Acquisition (SLA).

The section that follows gives an insight into blended learning (3.3), as the approach taken to language learning in this study. Here a special sub-section (3.3.1.) is dedicated to Learning Management Systems (LMS), Moodle in particular, as a tool used for creating a blended learning environment. This is followed by a section dedicated to the review of the literature on vocabulary development (3.4). Finally, the last section (3.5) in Chapter 3 discusses learner autonomy as a characteristic that learners need to have or develop when using new technology in learning.

Following the analysis of previous research carried out in the field, Chapter 4 describes in detail the study which is the basis for the dissertation. The first section of the chapter (4.1) provides the context of the study that is crucial for understanding the motivation of, and need for, conducting this research. It is followed by a section (4.2) presenting main aims and hypotheses of the study. 
The methodology of the study is described in detail in Chapter 5 through the main points of interest (5.1) which require a specific approach to the study presented in the next section (5.2) by referring to the hypotheses. It also provides with details of who participants of the research are (5.3) and on how the data was collected and analysed by looking at independent and dependent variables (5.4). This is followed by the description of the results obtained by the research which are presented in the context of this dissertation in Chapter 6 and discussed and related to the hypotheses presented earlier, and linked back to the literature that has been carried out previously in this area.

Chapter 7 provides readers with conclusions that this study has come to, based on the conducted research. These are accompanied by theoretical and practical implications (section 7.1) of the research, and its limitations (section 7.2).

Chapter 8 consists of the list of references that were used during this process and while working on the dissertation. The most important materials used in the research are presented as an Appendix in Chapter 9. 


\section{THEORETICAL FRAMEWORK}

This chapter will provide general insight into the research area of second language acquisition (SLA) by first explaining what is considered by the terms 'second language' and 'learner' in this dissertation. It will continue with a description of SLA as an interdisciplinary area of research. It will briefly refer to its historical development by mentioning key constructs which will be focused on later in the chapter to describe the topics of interest at the centre of this research and thus give an overview of the theories that provide the framework for this dissertation. Therefore, this chapter has two goals: to offer insight into the general concept of SLA from its early beginnings to the most recent research that makes it an important construct for exploring blended learning, vocabulary acquisition and learner autonomy, as well as to provide the theoretical framework for the study.

\subsection{Second Language Acquisition (SLA)}

The term second language in this dissertation refers to any additional language other than the mother tongue (Cook, 1993; Mitchell \& Myles, 2004); that is, any other language acquired by a person alongside their first language, regardless of the context in which it is learned. The term second language thus includes foreign languages and sometimes these two will be used interchangeably. In addition, in this dissertation, the focus of research is placed on the second language (the vocabulary in particular) that is taught and learned (through planned and organized activities) as well as acquired (as part of a spontaneous process) in a formal language environment. However, this difference will not be studied or discussed in detail since this is not the focus of the dissertation.

The other term that needs to be defined prior to discussing the topic of SLA is the term learner. It is used as a concept which encompasses the terms user, speaker or acquirer that appear in the literature, but it will also be sometimes used interchangeably with the term student when the author feels it is necessary to talk about learners as students of higher-education institutions.

After defining the terms second language and learner in the form in which they will be used throughout this dissertation, the general concept of SLA and its significance for the study will now be presented so as to lay the grounds for the theoretical framework that has shaped this study. 
SLA is a relatively young discipline whose aim has been to describe and explain the process of acquiring a second language. The term SLA is used both as the name for the discipline and the process of second language acquisition it deals with. According to Gass (1993:103), SLA "is concerned with what is acquired of a second language, what is not acquired of a second language, what the mechanisms are which bring that knowledge (or lack thereof) about and, ultimately, an explanation of the process of acquisition in terms of both successes and failures." Therefore, SLA takes into consideration complex processes of learning other languages besides one's first language. It is an area of research which "investigates the human capacity to learn additional languages during the late childhood, adolescence, or adulthood, once the first language, in the case of monolinguals, or the first languages, in the case of bilinguals and multilinguals, have been acquired.” (Ortega, 2011:171)

By taking all of this into consideration, it can be noted that SLA is an interdisciplinary field which reaches into other disciplines. It builds on results obtained from studies that are rooted in variety of areas, areas which all share a common focus on the processes related to language use and language learning (see Cook, 1993; Ellis, 1997; Larsen-Freeman \& Long, 1991; Long, 2012). Ortega (2009) gives a brief overview of this interdisciplinarity of SLA through its connection with language teaching, linguistics, child language acquisition, psychology, and more recently bilingualism, psycholinguistics, education, anthropology and sociology; she sees it as an asset to its autonomy and specialization. The issues SLA research deals with today are of importance not only for researchers, but also for people who are interested in language learning for personal reasons such as bilingual families, people who have migrated to another country and need to acquire a completely new language, or language teachers who would like to improve their pedagogic practices and find out more about how to support their students' second language acquisition.

The interdisciplinary nature of SLA can be traced through its history. The exact starting point of the interest in SLA as a research discipline is difficult to pinpoint; in most papers, it is usually agreed upon as the 1960s. Authors whose research focus is SLA offer similar insights into the development of the topic (Ellis, 2008; Hulstijn, 2007; Larsen-Freeman, 2018; Medved Krajnović, 
2010; Mitchell \& Myles, 2004). Myles (2010) pinpoints the start of the development of SLA in the period between 1945 and 1957 with the development of behaviourism. Without going into too much detail, it is a psychology-related approach used by language researchers such as Fries, Skinner, and Lado (and his contrastive analysis), who focused their research mainly on comparisons of the first and the second language. Medved Krajnović (2010) notes that the research conducted in the fields of contrastive analysis and error analysis was the most significant for the development of SLA as a discipline. The popularity of contrastive analysis decreased mainly because of Chomsky and his ideas referring to language acquisition as a creative process based on universal grammar (see White, 2003). This affects the works of Corder (see Corder, 1975) on error analysis: by being aware of a child's incorrect utterances in their mother tongue, some conclusions can be drawn with reference to the second language learner's errors and their control of input. The results obtained can be applied in developing second language teaching (see Sharwood Smith, 1994). Research focuses on concepts such as interlanguage, input, interaction, which will be described in more detail in the sub-section to follow. Another concept studied throughout the history of SLA that deserves to be mentioned is the critical period hypothesis which includes the age of learners as an important (but not only) factor in SLA ${ }^{2}$. For other researchers it is important to look at language learning as a mediated social process, which challenges cognitivist and mentalist views of language learning. This period is marked by Lantolf and his work that is rooted in the Vygotskyan sociocultural framework.

Larsen-Freeman (2018) offers her vision of the future of research, and she emphasizes several directions she thinks SLA will go in. Among them is the one that is being investigated in this study according to which technologies open up new possibilities for language learning which consequently moves away from schools and is directed towards virtual spaces, whether it be by using computers or mobile phones. In this way, new forms of interaction are possible: they enable learners to focus on learning for various purposes and to a different extent. This dissertation and

\footnotetext{
2 This period (late 1980s and 1990s) is of great importance for Croatian SLA development in which a significant amount of research was conducted, and it shed some light on SLA being influenced not only by age, but also by the interaction of factors that represented a dynamic concept of the programme, teacher, and motivation (see Medved Krajnović, 2010, for a detailed overview of this period of SLA research).
} 
the study it describes can be recognized as belonging to the above-mentioned 'future research' since the focus is placed on using technology for the purposes of second language acquisition, with specific emphasis on changing the approach to the acquisition of vocabulary in the context of English for specific purposes.

These preceding paragraphs have shown that in the field of SLA research the focus has been changing - from a comparison of the first and second languages, to the second language being studied independently alongside and in interaction with a variety of concepts. Some of these are rooted in other disciplinary areas, which means the field of research is still evolving. As Long has put it (2012), even though the focus of SLA very often causes disagreement due to variety of theories that are associated with it, the majority of researchers deal with issues such as implicit and explicit learning, incidental and intentional learning, automatization, developmental sequences, variation in interlanguage development, input, and interaction. Researchers who look at language learning from a sociocultural perspective and who understand language learning as a social process, would add a number of concepts to this list, such as mediation, the zone of proximal development, emergentism, and the importance of context. Some of these terms will be discussed later.

As the overview of SLA research above has shown, there exists no single theory that would offer a comprehensive view of the area. Instead, various theories exist side-by-side, theories that deal with the language learning process, how this is realized and how it consequently leads to acquisition (Mitchell \& Myles, 2004; VanPatten, 2018). In the introductory chapter of the book dedicated to the theories of SLA, VanPatten \& Williams (2015) define the term theory (whose aim is to explain phenomena, predict what would happen to them with regard to various conditions, and unify generalizations) and give examples to make the term more easily understandable. They create a list of ten observations in the field of SLA which should be the focus of research:

(1) Exposure to input is necessary for SLA.

(2) A good deal of SLA happens incidentally.

(3) Learners come to know more than what they have been exposed to in the input.

(4) Learners' output (speech) often follows predictable paths with predictable stages in the acquisition of a given structure. 
(5) Second language learning is variable in its outcome.

(6) Second language learning is variable across linguistic subsystems.

(7) There are limits on the effects of frequency on SLA.

(8) There are limits on the effect of a learner's first language on SLA.

(9) There are limits on the effects of instruction on SLA.

(10) There are limits on the effects of output (learner production) on language acquisition.

In this dissertation, three of the aforementioned observations will be addressed in more details within chapters and will be referred to when discussing the results of this study. The first observation, which is that exposure to input is necessary for SLA, refers to the presumption that in order to acquire language, learners need to be exposed to input the meaning of which they can comprehend and thereby can react to the message accordingly. In this study, learners are uniquely exposed to input in two different learning environments (face-to-face and blended) and both to different extents, which will be described in detail in the sections to follow. The next observation that a good deal of SLA happens incidentally, means that when learners are exposed to input and focused on the message it contains, they acquire certain linguistic features incidentally. In this study, this is discussed in the context of the example of students reading texts related to their professional engineering topics while looking for examples of conditional sentences and at the same time incidentally acquiring vocabulary. The observation that there are limits on the effects of output (learner production) on language acquisition relates to the notion that acquisition can but does not have to be affected by learners' production. In this study, it will be discussed that successful written production achieved by a group of learners in a blended learning environment can affect their vocabulary acquisition and development. In this sense, this dissertation will focus on how SLA theories can be used to explore the use of technology and blended learning for vocabulary acquisition and learner autonomy in an ESP context. The focus that is placed on these areas and how they relate to the study has been described in the introductory chapter, "Rationale".

This section provided general insight into the research area of SLA, first stating the meaning of the terms second language and learner used in this dissertation, followed by discussion about the interdisciplinary nature of SLA. By giving an overview of its historical development and 
introducing key constructs of SLA research, the theories and key concepts that provide the framework for this dissertation and its conclusions have been discussed. Since the focus of this dissertation is placed on language input in second language acquisition and its use in a blended learning environment, SLA theories of input and interaction will provide the conceptual framework for the study. Therefore, the next section is dedicated to discussing this in more details.

\subsubsection{Theories of Input and Interaction}

Previous paragraphs described SLA as an interdisciplinary field and provided some general information on what it is and what it deals with. The following paragraphs will give additional details on the theories that will provide the framework for this dissertation and thus offer background for the study that will be described later.

As mentioned earlier, different approaches to learning and studying language have triggered new research related to what is today considered to be one of the key constructs of SLA - interlanguage. In this study, the focus is not placed on interlanguage per se; however, in order to clarify that learners differ in how they acquire language not only based on their personal traits and life experience, but also based on the context of acquisition, it is necessary to discuss interlanguage as part of the process of learning a target language that depends on input, intake and the knowledge needed to produce a (desired) output described later in this section.

The term interlanguage was coined by Selinker (1972:209-210) who, in trying to point out important 'theoretical preliminaries' necessary for better understanding of second language learning, clearly differentiated the learning and the teaching perspectives. While the teaching perspective encompasses what the teacher should do to help the learner learn a second language, the learning perspective focuses on the attempted learning itself, without emphasis on success. Positioning himself in the learner perspective he coined the term interlanguage, which he used to refer to the separate linguistic system that learners use while learning a language. This system explained the difference in output in the target language produced by native speakers and those produced by second language learners. Its characteristics are that it gradually develops during the exposure to the target language, it can be described, and is somewhat predictable. Selinker mentions several processes that he considers to be 'central' to second language learning: language 
transfer, transfer-of-training, strategies of second language communication, and overgeneralization of target language linguistic material (p. 215), which can help predict how this learner language is developed. Interlanguage at a certain point can reach its peak with fossilization, that is, when the learner stops developing their interlanguage or parts of it due to various reasons (such as their own decision to stop developing it or due to insufficient input) (see Long, 2003).

The linguistic system of native speakers learning their first language differs from that of learners of a second language, but also from that of learners learning a third or subsequent language. It means that language learners share certain predictable parts of interlanguage, but there are other influences which cannot be predicted or even identified. Language learning is an active process; it develops with the learner's interlanguage, which is affected by the mother tongue, other languages the learner is attempting to acquire, their personal characteristics, and the context where this acquisition takes place. Interlanguage at the same time presents "the first attempt to take into account the possibility of learner's conscious attempts to control their learning." (Pavičić Takač, 2008:32).

Since its first appearance the notion of interlanguage has not changed much, even though there have been minor modifications to Selinker's hypothesis. Han \& Tarone (2014) have provided details on how the concept of interlanguage has been modified in the last forty years. As Sharwood Smith (1994:42) summed it up, the 1970s were the period in which some of the core notions of SLA were identified and researchers were ready to start accepting them, for example that SLA was a systematic and complex process, that SLA could be compared and related to the development of mother tongue to some extent, that learners do not have conscious control over language development, and that they often rely on intuition - similar to a child learning a language. Based on this similarity in terms of processes of child language acquisition and second language acquisition, another construct needs to be introduced. It is Krashen's Monitor Model (1982) which was one of the first attempts to theoretically explain various second language acquisition processes. Even though some of the premises have been rejected, Krashen remains relevant in SLA and many researchers continue to use his model. It is central for understanding the field of SLA research as a whole since it can provide an explanation for "why what is taught is not always learned, why 
what is learned may not have been taught, and how individual differences among learners and learning contexts is related to the variable outcome of SLA." (VanPatten \& Williams, 2015:25). With that in mind, Krashen's hypotheses will be described in the paragraphs to follow and some comments on how they could be applied in second language teaching will be given.

Krashen's model (1982) encompasses five hypotheses. In the first one, the acquisition-learning hypothesis, he points to a clear difference between learning and acquisition. Adult learners, unlike children, when attempting to develop second language competence can choose from two ways to achieve that desired goal: one is through language acquisition and the other is through language learning. The first way, acquisition, is subconscious in terms of the process and its result, and it is thus similar to a child acquiring their first language. Learners are only aware of using the language for communication in an accurate way by subconsciously knowing that the linguistic form is correct only based on the exposure to the linguistic content or the received input. Other terms Krashen uses to describe acquisition are implicit learning, informal learning, natural learning, or simply pickingup a language. In contrast, learning is a conscious process where the learner is aware of grammar and rules of the language they are attempting to learn. Other terms he uses to describe learning are formal knowledge or explicit learning. This dichotomy leads to the understanding that adults, and not only children, can acquire a foreign language even though they will probably not succeed in achieving the levels of proficiency of native speakers due to the aforementioned fossilization. According to this hypothesis, these two processes, acquisition and learning, are completely separate, and error feedback is in most cases useless. Nevertheless, in this dissertation learning and acquisition are used interchangeably because being exposed to the English language most of the time at home, at school or at work, learners acquire the language through informal learning without even being aware. Both terms are used in this dissertation as part of formal learning in the form of explicit and implicit learning of grammar and vocabulary. In addition, the focus of this dissertation is not placed on defining the difference between these two concepts.

The second hypothesis is the natural order hypothesis which Krashen based on previously conducted research (see Brown, 1973) that provided some evidence that the system of second language acquisition is predictable in its development by following an order. According to it, 
certain grammatical structures or function words are acquired earlier than others, which is similar to children acquiring language by going through the same phases of acquisition regardless of their environment.

The natural order hypothesis is followed by the monitor hypothesis, which is closely related to the acquisition-learning hypothesis. It emphasizes the difference in how acquisition and learning are used: acquisition triggers language production and thus enables our spontaneous language use, while learning controls or monitors the production and enables correction. However, learning is successful only under certain conditions: when there is enough time to think about the rules (which usually does not happen in speech), when the focus is placed on the form or how learners are saying something, and when they know the rules. Only when these three conditions are met, we can talk about successful monitoring and then self-correction is applied. Nevertheless, this monitor should not interfere with communication, which is achieved with optimal monitor users (Krashen, 1982:20). For the benefit of communication, teachers should be careful not to focus too much attention on accuracy so as not to negatively affect fluency of the learner.

The fourth hypothesis is the input hypothesis. It is a relatively new hypothesis and the one that explains how we acquire language. According to this hypothesis, in order for learner to move from one stage (i) to a higher level $(i+1)$, it is necessary for the learner to understand the learning content or structures not yet acquired. This is possible if we focus on communication, and not on the form; only then acquisition takes place. Krashen claims that it is possible for the learner to know the $\mathrm{i}+1$ structure because we learn through the context or extra-linguistic information. If the learner is familiar with the learning content or the topic, it will be easier for them to learn the language by using their knowledge outside the language itself.

With regard to this study and dissertation, this extra-linguistic information is the context of the profession for which students are studying (e.g. mechanical engineering students are familiar with the topics related to their profession and the knowledge they already possess will ease the introduction of new profession-specific vocabulary due to their previous understanding of the input). Therefore, in the case of foreign language learning, the teacher's task is to help the learner raise to this higher level $(i+1)$ by providing the learner with input which is slightly above the ' $i$ ' 
level and thus reaching the $\mathrm{i}+1$ level. This input that contains language which is slightly above the level of the learner's knowledge of the language Krashen calls comprehensible input. As long as the input we receive is enough and is understood, this higher level is available. In case this input is much above the learner's level, it becomes incomprehensible and does not direct towards learning. The teacher's task is to ensure that the learner is exposed to a comprehensible input at an appropriate level, that is, not too simple or not too complex. However, not every input will be comprehended by the learner - the amount of input that is grasped by the learner is then called intake. "Input refers to what is available to the learner, whereas intake refers to what is actually internalized (or, in Corder's terms, "taken in") by the learner.” (Gass, 2013:340) In other words, we do not necessarily need to understand all the language we are exposed to (input), but that portion that we can understand and therefore use for acquisition is actually comprehensible and can be referred to as intake (Truscott \& Sharwood Smith, 2011). Following this point, teachers should carefully think about materials used for teaching a language because students need to understand them enough for their language acquisition.

The fifth and the last hypothesis is the affective filter hypothesis. Its goal is to explain why there are certain second language learners who, even though they are exposed to larger quantities of comprehensible input, cannot acquire the language to a desired level, if at all. Krashen claims that affective variables, such as attitudes, motivation, self-confidence and anxiety affect whether someone will be successful in the second language acquisition or not. Therefore, in the classroom, where the situation is under control, the teacher should not only focus on the comprehensible input, but also on ensuring low-filter situation because this enables the learner to acquire the needed comprehensible input. This filter is not present in children learning their first language and therefore presents a situation different from the one when acquiring a second language, and should therefore be taken into consideration when conducting research in the SLA field. Even though there is no evidence that such a filter exists, teachers should take into consideration all the possible issues that might affect learning (stress, anxiety, motivation, etc.).

Krashen's Monitor Model has been criticized for its problematic empirical testing and for its circularity and vague concepts (Gass, 2013; Gregg, 1984; Larsen-Freeman \& Long, 1991; 
McLaughlin, 1978; Payne, 2011; also see Krashen, 1979). Consequently, Cook (1993) refers to Krashen's ideas as 'both stimulating and frustrating' (p. 65). 'Frustrating' because these hypotheses lack evidence, 'stimulating' because they make sense for a user and their plausibility and inclusiveness. 'Stimulating' can also be associated with the fact that these concepts triggered other research which has contributed to the development of SLA, especially in relation to Krashen's input hypothesis. It can also be related to educational settings since, according to Krashen, the classroom is a very fruitful place for second language acquisition because input can be controlled. This means teachers can make sure they provide learners with comprehensible input by assigning purposeful activities that would support language acquisition since it might be difficult for learners to receive comprehensible input outside the classroom. In this way, in a controlled and stimulated environment, the focus can be placed on the desirable output, which is in most cases quality communication in a foreign language important for a (specific) situation during a successful social interaction. In order to learn a language, we need to use it; in order to be able to use a language, we need to learn it.

Language, whose main function is communication, necessarily implies some social interaction. The process of second language acquisition takes place in a social context which affects the process of acquisition. It is not the same whether the learner is immersed in the language they learn due to their living conditions or they learn it to achieve specific knowledge or skills needed for successful business communication. The input is different and the amount of exposure to it is different. In the literature, we can find evidence that input is needed, but that it is most efficient during communication between second language learners, even more than during that interaction between second language learners and more proficient or native speakers of the language (e.g. see Long, 1981; Long, 1983; Gass, Mackey, \& Pica, 1998; Gass \& Varonis, 1994; Polio \& Gass, 1998). Research has shown that more proficient speakers (not necessarily native speakers) of the language help those less proficient speakers by using various communication strategies and modifying and simplifying their speech to communicate the message effectively and to increase comprehension (Long, 1983; Varonis \& Gass, 1985). This led to the development of Long's interaction hypothesis. This hypothesis, as explained by Ellis (1991:8), can be summarised in three parts: comprehensible input is crucial for the development of the learner's interlanguage; comprehension can be promoted 
by modifying conversational structures; and, the conditions that create opportunities for restructuring need to be taken into consideration. Therefore, with those input modifications, the second language learner can receive feedback needed for correction with a greater focus on language. The modifications are useful and necessary when communication is interrupted, and learners have the opportunity to negotiate what was not understood by checking comprehension or requesting clarification (Gass, 2013:349).

Comprehensible output, as the remaining construct which needs to be explained alongside input and interaction, is also important for SLA. Swain (1995) focuses on the importance of language production for SLA because the learner enhances fluency by practicing the target language. Using the language, the learner becomes aware of their own language production and notices the gap in their linguistic knowledge or notices the error in their own language production, which leads to its correction through further interaction. Hence, the learner is able to modify the output, which either leads to new linguistic knowledge or consolidation of the already existing one. Furthermore, the learner tests their own hypotheses on how the language functions, especially with regard to 'erroneous production'. And finally, by communicating about the language using the language itself, the learner negotiates meaning by focusing on the form, which leads to reflection and increased metalinguistic awareness (see Kawaguchi \& Ma, 2012). Interaction between more and less proficient language users can be observed as a good way of encouraging language acquisition since the learner can benefit from it by modifications of interlanguage which enable language acquisition (Arnold \& Fonseca-Mora, 2015; Tudini, 2003). By being aware of their target language use, their output, they are able to control their learning. This leads to a greater responsibility for their own learning, which consequently supports acquisition.

It can be seen that Swain's output hypothesis does not exclude input - input is a necessary and important part of SLA, but the emphasis is placed on output. Swain (1998) provides evidence on the importance of both input and output for learning, as well on the existence of the need for some constructive feedback to learners regarding their language errors. All of this combined together will help learners deal with their potential language weaknesses (p. 76). 
On the other hand, Krashen (1998) claims that output does not lead towards acquiring the second language; it only controls knowledge that has already been acquired. He claims that comprehensible output can be a cause of anxiety for the learner because they have to deal with anxiety or frustration due to being pressured to produce language, which prevents them of internalizing the input they are exposed to, therefore intake does not happen as it should.

Previously described constructs of input, interaction, and output in second language acquisition have been integrated (Gass \& Mackey, 2006) and on the basis of advancements in SLA research, they are generally referred to in the literature as the Interaction Hypothesis/Approach which includes "some aspects of the Input Hypothesis (e.g., Krashen, 1982, 1985) together with the Output Hypothesis (Swain, 1985, 1995, 2005). They have also been referred to as the input, interaction, output model (Block, 2003) and interaction theory (Carroll, 1999)." (Gass \& Mackey, 2015:180).

In order to understand the process of second language learning from the point of view of the interaction approach and based on the aforementioned literature, the following needs to be taken into consideration: the learner needs to be exposed to language, which is called input, in order to produce language, which is called output, both realized through interaction, which has shown to positively influence second language development (Mackey, 1999) and is therefore valuable. Very often meaning is negotiated, or adapted for the learner during interaction. This is when the learner can learn a language - by communicating. However, in this study, interaction is not limited to conversation between learners or between a learner and a speaker of the language; it is realized by the means of a computer, or, to be more precise, through the blended learning environment, which will be discussed in details later in Chapter 3.

One of the aims of this sub-section has been to give a detailed insight into the constructs and theories/hypotheses that are important for the SLA research. Of course there are others which have not been mentioned here, but they are less relevant for this dissertation. The constructs that have been mentioned - interlanguage, input, intake, output and interaction - set the theoretical background for this research. Input and interaction theory focuses on the process of using language input for second language acquisition and how this can be done effectively. Learners differ in terms 
of rate of second language acquisition, learning processes and outcomes (Ellis, 1994; Cook, 2003; Ortega, 2011). This is particularly noticeable at tertiary institutions where some students study full time and others study and work at the same time and whose learning goals and behaviour often differ as a result. In an ideal situation, teachers would adapt their teaching to the individual needs of students in order to facilitate language development. It is crucial to ensure that students use their knowledge of the world to make input comprehensible (Krashen, 1982; Long, 1983; Ellis, 1991). By becoming aware of a gap in their linguistic knowledge, students are able to modify their output (Swain, 2000), and in doing so, they acquire the second language. Teachers should do everything in their power to provide students with input that would lead to a desirable output by enabling interaction that would give learners the opportunity to expand their knowledge.

Another approach to understanding the role of interaction in second language learning is offered by sociocultural theory, and applying its insights into learning to second language learning, using the notion of mediation, sociocultural theory posits that social interaction is the primary means of mediation between a teacher and a learner (Ellis, Skehan, Li, Shintani, Lambert, 2019:105). While SLA focuses mainly on the cognitive processes around acquiring a second language, sociocultural theory focuses on the interaction between a learner and the context by means of a mediating tool. This approach broadens psycholinguistic approaches to interaction in second language by focusing on the importance of context in a formal language learning environment and for example understanding computers as a mediating tool alongside language.

According to Vygotsky (1986), a Russian psychologist, people develop within the social environment in which they actively participate and change by using tools, one of these tools being language. Interaction is what allows them to learn and therefore change. In this dissertation interaction refers to interpersonal interaction between students (through collaboration via computers) and between a student and a computer in a blended learning environment.

To give better insight into interaction from a sociocultural perspective, we need to mention other researchers who contributed to this field. In her book, Ortega (2009:218), states that two researchers should take the credits for applying Vygotsky's knowledge of psychology to SLA: James Lantolf and Merrill Swain "have opened the way for many others to reconceptualize L2 
learning through a Vygotskian prism, leading to a steady and vibrant growth in the current size and scope of Vygotskian SLA research", Lantolf by using Vygostky's psychological ideas to explain processes in SLA and Swain by adapting the concepts of interaction and output.

Lantolf \& Thorne (2007) name several key constructs for sociocultural theory: mediation, internalization, regulation, the zone of proximal development, and the genetic method. To give a better insight into these constructs, the following several paragraphs will give a brief description of each of these constructs and mention their significance for second language acquisition.

The central term in sociocultural theory is mediation which implies that the relationship between humans and the world is established through physical and symbolic tools and consciously using them affects how humans think or perform various activities (Lantolf, 2000; Lantolf \& Thorne, 2007; Lantolf, Thorne, \& Poehner, 2015). One of these symbolic tools is language - by using language, people express their thoughts, desires, needs, etc., and at the same time it affects how and what people learn and how they perceive the world around them. Since humans have consciousness, they regulate their actions to achieve what they want or need. Lantolf and Thorne (2007) talk about three kinds of regulation, each of them appearing in a certain phase of human development: object-regulation, other-, and self-regulation. The first, object-regulation, is the type of regulation which is typical for the time when child is focused on objects that surround them and by using them they think, but at the same time, they can easily be distracted by other objects in their environment. Then, later, child becomes other-regulated. This means that people from the child's surroundings mediate - they assist in activities which are too demanding for a child to do on its own and this way affect how the child continues to perceive the world. Ortega (2009) gives an example of this stage when the child and the parent cooperate - the parent assists the child to manage a cooking act, whether it means only giving instructions, or performing certain activities instead of the child (chopping the vegetables). The final stage of regulation is self-regulation, which is the phase in which the child can manage to perform an activity without anybody's assistance. This is the stage which is made possible through internalization as 'the process of making what was once external assistance a resource that is internally available to the individual' (Lantolf \& Thorne, 2007:200). Simply put, self-regulation is achieved when a person does not need an object 
or another person to perform a complex mental activity; however, every person can go back to previous phases when an activity is too complex or too challenging (ibid.). These types of regulation and mediation can be noticed when learning a second language - it is a process that requires the learner to use that language as a tool that would help them achieve the final stage of regulation: self-regulation. The teacher has an important role in the beginning of the process whereas later, their role becomes less prominent since the student's task is to learn how to work on their own, without anybody's assistance.

In line with this, computers can influence the process of learning. Chapelle (2005), using Vygotsky's work as a fundamental starting point, gives an overview of the interactionist SLA and discusses the term interaction by mentioning benefits that create "opportunities for negotiating meaning, obtaining enhanced input, and directing attention to linguistic form" (p. 55). Interaction implies communication exchange between at least two parties; she mentions interpersonal (between people, and between a person and a computer) and intrapersonal interaction (within the person's mind). When considering interpersonal interaction, this can be realized between two or more learners, or a learner and a teacher. If it is realized between a learner and a computer, it can therefore be considered in the context of using technology in language learning. Since the interactionist approach focuses on the way input is modified with the purpose of language acquisition (Trawiński, 2005:17), the modification in case of learner-computer interaction is observable in the example when a learner modifies the input (e.g. a text) by using an online dictionary to clarify the meaning of individual words or phrases, which helps vocabulary acquisition. In addition, while using computer, the learner has the possibility to refer to the helpful dictionary content as many times as needed, which is not always the case in face-to-face communication. In this way, comprehensible input is obtained during the learner-computer interaction and can be turned into intake. From the interactionist point of view, mediation can be noticed in the process of using computers as tools: mediation is present, for example, when using an online dictionary; reading or writing would be a good example of object-regulation; an example of other-regulation would be mediation by a teacher when giving feedback on grammatical form; self-regulation would refer to using the learned words to produce a new sentence in creating a wiki. 
Moreover, how sociocultural theory can be applied to using computers in language learning contexts can be seen in Warschauer (2005), who provides an analysis of how Vygotsky's sociocultural theory can contribute to understanding computer-assisted language learning (CALL), focusing on the earlier mentioned notions of mediation, social learning and genetic analysis.

Since mediation has been explained at the beginning of the section, the two remaining constructs are social learning and genetic analysis. Social learning refers to a learner's interaction whose goal is to "advance through their zone of proximal development (i.e., the distance between what they could achieve by themselves and what they could achieve when assisted by others.)" (Warschauer, 2005:42). This can be applied to the use of computer mediated communication (CMC) which enables interaction among learners in various ways, whether by means of online discussions or that of various written projects (Bekar \& Christiansen, 2018; Peterson, 2009).

The last aspect is genetic analysis, which refers to understanding various concepts and their meaning only by understanding their background and the broader context they appear in - such as that understanding motivation for using technologies in the classroom is possible only through understanding the importance of technology in today's society. For that reason, this study will later discuss the importance of technology for undergraduate students with an emphasis placed on their professional needs, which in this study refer to communication in English for specific purposes. Thus, the following section will provide a more detailed view of the context in which language teaching and learning is realized in this study, one which is closely related to the learner's profession.

\subsection{English for Specific Purposes (ESP) Context}

Another concept that needs to be discussed and described in more detail for the purpose of this study is English for specific purposes (ESP). The reason for that can be found in the fact that the main constructs of this study (blended learning, vocabulary, learner autonomy) are placed within an ESP context, as the dissertation title states. For this reason, this chapter will examine the area of English for specific purposes in detail, from its early beginnings to its place today, as well as to the importance it has in this study. In addition, this chapter will discuss ESP's position today with regard to technology, vocabulary acquisition and learner autonomy. The following paragraphs 
discuss how ESP has developed over time (including the phases it went through) and the ways ESP is perceived in the language learning community. Then, motivation is discussed as one of the notions often related to learning in an ESP context, which in this study is using technology to learn technical vocabulary in English at a higher education institution in Croatia.

"Tell me what you need English for and I will tell you the English that you need" (Hutchinson \& Waters, 1987:8). This sentence summarizes the underlying function of ESP - meeting the learner's needs to develop the language skills they need in professional communication. ESP is seen as "an approach to language teaching in which all decisions as to content and method are based on the learner's reason for learning". (ibid.:19). Learners of ESP are usually adults who already have some English language knowledge, but they have the need to communicate in a professional environment for various (often work-related) reasons. They tend to be university or vocational students or language learners in a specific professional field. This makes it different from general English, which is intended to develop skills needed to participate in daily cultural and social activities or environments (Hans \& Hans, 2015).

The beginnings of ESP can be tracked back to the 1960s when ESP developed for two reasons: the political situation after WWII that meant that specialist language knowledge was needed in technology and commerce; and the general interest in languages which shifted from form to function, from grammar to communication, and aided in realizing that various professions needed slightly different specialist language to communicate effectively. The learners and their needs came into focus, which together with their interests and motivation directed the course of learning, thus accelerating change (Hutchinson \& Waters, 1987; Johns, 2013; Rahman, 2015; Veselá, 2012). ESP developed at a different pace in various countries and its importance varied. For example, in Croatia, at various tertiary education institutions in different fields (economics, tourism, engineering, etc.), ESP has been continuously shifting from being a compulsory course and therefore important for a profession, to being an elective course of minor significance for both the learners and the management (Ciglar, 1982; Grabar \& Kolednjak, 2018; Matić \& Matić-Bilić, 2008; Sobočan \& Miščančuk, 2017; Violić-Koprivec \& Dubčić, 2010). However, one factor keeps being forgotten: by learning ESP, students become equipped for today's global market where 
English is the lingua franca (Kankaanranta \& Louhiala-Salminen, 2017). Hyland (2002) emphasizes the importance of ESP as an approach which is focused on identifying specific language features, discourse practices and communicative skills, and on learners' needs. This makes it indispensable in today's globalized world, and if universities were to look at it in this way, their doubts regarding the need for teaching foreign languages in general and ESP in particular might be dispelled.

During its development, ESP went through several phases (for details see Hutchinson \& Waters, 1987), just like other approaches to language learning, from being completely focused on form to later becoming more focused on learners. The most important achievement through this development process has been the shift towards the learner's needs, which have become central in designing the course and course materials. According to Robinson (1991:3), ESP is characterized by being goal-directed. Prior to designing a course, it is crucial to know what the learners' needs are. That is why carrying out a need analysis is quite common in ESP (Brown, 2016; Flowerdew, 2013; Spence \& Liu, 2013). If students' needs are recognized, it is possible for students to achieve their earlier established goals with regard to learning the language. Learning takes place only when the content that is being learned is meaningful. If the content is meaningful, the students should be more motivated to learn. If taking into consideration Gardner and Lambert (1972), learners do most of their everyday activities guided by their emotions; therefore, it is necessary to ensure that ESP is intrinsically motivating for learners. This is necessary because learners have expectations regarding ESP courses. One of these is to acquire specialist vocabulary needed for communication in their profession and the language that is closely related to the subject. This might mean specific technical vocabulary which is usually not covered in general English classes, but also particular grammatical or structural forms that are typically used in a particular profession (Hutchinson \& Waters, 1987:165). Specific vocabulary and forms are of great importance for ESP and therefore the awareness of what vocabulary ESP learners really need has to be raised (Coxhead, 2013), as mentioned earlier in this section. When these learners are higher-education students, it is important for them to learn both the language and the specialist content so that they can successfully communicate in international markets (Johns, 2013). When it comes to various engineering fields, which are the focus of the course described in this study, students are mostly interested in reading 
professional texts, discussing professional issues and acquiring specific vocabulary. As mentioned before, if the course is designed to meet the students' needs, close attention needs to be given to the course materials, its syllabus, meaningful activities, and using various techniques and tasks, all of which can help develop ESP learning (Brunton, 2009; Tzoannopoulou, 2015; Spring, 2012). The analysis of students' attitudes shows that the combination of general and specific English with emphasis on a selection of interesting topics is the highest motivator for doing course work due to the students being aware of the connection between teaching and their profession (see Kember, Ho, \& Hong, 2008; Kordić \& Mujić, 2003). Thus, ESP learners can be motivated if they see the purpose of their learning or if they are aware of the need.

In addition to being motivated, students need to have positive attitudes towards the subject matter in order to turn input into intake and acquire the language. Much research has been done on the attitudes that learners have towards learning ESP and has shown mostly positive attitudes towards learning a foreign language (Al Hinai, 2018; Amengual-Pizarro, 2017; Ardeo, 2003; Arslan \& Akbarov, 2012; Jelovčić, 2010; Kordić \& Mujić, 2003; Martinović \& Poljaković, 2010). However, there are some negative attitudes, too, which are usually related to lower motivation due to lower language knowledge or unrelated course materials (see e.g. Alqahtani, 2015; Loan, 2017; Navickienė, Kavaliauskienè, \& Pevcevičiūtè, 2015). Teachers can help with this, but it is necessary for students to become acquainted with the subject matter and become learners of the discipline themselves and therefore share both knowledge and interest (Bojović, 2006; Hutchinson \& Waters, 1987). Thus the role that the teacher has in ESP is to a certain extent different from the one that a general English teacher has. Sometimes this role presents problems that need to be acknowledged and dealt with, such as the language course having a minor role when compared to other university courses or the ESP teacher not having sufficient contact or communication with the subject teachers (Hutchinson \& Waters, 1987; Kordić \& Papa, 2014).

According to Carver (1983), there are three main characteristics of ESP teaching: using authentic materials that can be modified by the teacher; orientation towards a purpose that is used to teach students communication within a target situation such as preparing for a conference presentation in English; and turning students from language learners into language users, which means 
encouraging a certain level of autonomy with students. By providing students with authentic materials teachers can be sure that they will expose students to input needed for their special purpose, usually specialized vocabulary or grammar structures typical for their profession.

If teachers manage to find and offer ways of helping students to gain control over their learning and task performance, they will be actively involved in their studies and become actively responsible for their learning (Hyland, 2013). One of the ways teachers can motivate learners is by using technology (see Arnó Macià, 2012; Bloch, 2013; Bourne \& Moore, 2005; Dashtestani \& Stojković, 2015). Moreover, using technology ensures that learners have sufficient amount of authentic material at their exposal. Consequently, they can interact with it at a time and a pace that suits them. In this way, the emphasis is placed on developing learner autonomy. There is evidence that blended learning, or the combination of traditional (face-to-face) and online learning, which will be discussed in detail in the following chapter, is an excellent approach to ESP due to its availability or flexibility, including its use for supporting autonomous learning (see e.g. Banditvilai, 2016; Chirimbu, \& Tafazoli, 2014; Dziuban, Moskal, \& Hartman, 2005; Fučkan Držić, Seljan, Mihaljević Djigunović, Lasić-Lazić \& Stančić, 2011; Lungu, 2013).

This chapter has highlighted the importance of the ESP context for tertiary level of education and has therefore given an insight into the field of ESP. By looking at its development, it has discussed the position of ESP and importance it has today. ESP will be discussed in more depth in the chapter to follow, particularly with regard to the literature in the areas of technology, vocabulary acquisition and learner autonomy - the key constructs that are in the focus of the study and this dissertation. In addition, this chapter has provided the theoretical framework for this dissertation by discussing in detail second language acquisition and related constructs, with special emphasis being placed on the theories of input and interaction. In addition, it has also described the ESP context of language learning as it is important as the context in which language is learned at a tertiary education institution by students who participated in this study.

Next chapter will present literature review to indicate how the study that will be described in Chapter 4 corresponds to the most significant and quite recent literature on the topics of blended learning, vocabulary acquisition and learner autonomy. 


\section{LITERATURE REVIEW}

As the title of this dissertation suggests, this study relates to a number of areas of research, that is, blended learning, vocabulary acquisition in the context of ESP described earlier in Chapter 2, and learner autonomy. These will be examined in the review of published research literature in this chapter. The research will be scrutinized through the prism of second language acquisition so as to take into account the theoretical background of the study. The areas will be individually discussed through analysing previous research carried out in the field, thus showing how the study builds on existing research outcomes.

Before considering blended learning, it is important to discuss the importance of Information and Communication Technology (ICT) for language learning so as to provide the background for choosing blended learning as a learning environment at a tertiary institution in this study. Therefore, the order of presenting the literature on the concepts which are of importance for the study will be as follows: first, ICT and its integration into language learning will be discussed; then, computer-assisted language learning (CALL) and computer-mediated communication (CMC) will be focused on as constructs closely related to language acquisition using technology; then, blended learning will be explored as the approach taken to language learning in general and vocabulary acquisition in particular; next, vocabulary acquisition as the specific language learning aim will be examined; and, the final focus will be on learner autonomy as a characteristic that learners need to have or develop when learning using technology, whether it is performed completely online or in a blended learning environment.

\subsection{Information and Communication Technology in Education and Language Learning}

This chapter will start by generally discussing the potential that ICT has in education before focusing on its role in language learning. It will describe certain potentials alongside various challenges from the perspectives of both learners and teachers and discuss these. In addition, it will give more detailed insights into the role that Computer Assisted Language Learning (CALL) and Computer Mediated Communication (CMC) have for second language acquisition.

Technology is ubiquitous in education and is being used more than ever since it offers new learning opportunities for students (Jones \& McLean, 2018; Siemens, Gašević, \& Dawson, 2015; Wastiau, 
et al., 2013). ICT has great potential in education - from the practical benefits of reducing the costs of teaching and increasing capacity at universities to the possibility of improving interaction between students and teachers and encouraging dialogue between students (Bowen, 2013; Fu, 2013). However, some caution is required: education is affected by the fast development of technology, which implies that using technology also requires (fast) changes in education. Even though the costs of ICT equipment or various software licences can be quite high, they should be considered investments since they are seen as helping to attract prospective students. Therefore, technology can be of great use, but, according to Chambers (2001), there is a risk of placing emphasis on technological innovation rather than its role in the language learning process. This can be avoided if researchers develop an adequate theoretical and pedagogical approach. The issue here is that the speed of technology development is faster than the speed of pedagogic changes since it takes time to identify, assess and implement the benefits and manage the drawbacks that teaching aided by technology can pose. Solely using technology for technology's sake is not enough to improve teaching and learning - other matters should be considered, such as how and why it is used. Thus, innovations should not be driven by technology (Kirkwood \& Price, 2005; Kirkwood, 2013; Sarieva \& Zoran, 2007).

New digital technologies have been taken up in the field of education due to their ability to "bring together traditionally separated educational technologies - books, writing, telephone, television, photography, databases, games and more. In consequence, they bridge forms of knowledge and literacy, and they intersect places of learning - home, school, work and community." (Livingstone, 2012:9-10). This convergence enables various learning options in education, such as delivery of lectures through recordings, providing online interaction between teachers and students, giving students access to resources for self-study, and providing sites for online collaborative group work. The following paragraphs will give a more detailed account of these options.

Papers published in Huang, Kinshuk, \& Price (2014) give evidence of how ICT can be generally used in various ways as a support to teaching and learning in various areas of education (basic education, technical and vocational education, distance and continuing education, and higher education) through creating multidimensional learning environments (Madden, 2014); using 
laptops on a daily basis supported by all the stakeholders - principals, teachers and learners (Light \& Pierson, 2014); or using advantages of online learning (Lee \& Im, 2014).

ICT is a central tool supporting teaching and learning in the 21 st century at primary and secondary levels of education (Lai, 2008; Sutherland, et al., 2004; Voogt, Knezek, Cox, Knezek, \& ten Brummelhuis, 2013). When it comes to the use of ICT in higher education, which is the focus of this dissertation, universities use technology to make themselves attractive to students, for example by developing new learning platforms adapted to specific users (see Okamoto, Anma, \& Nagata, 2014). Also, platforms such as Massive Open Online Courseware (MOOCs) have also shown to have certain educational benefits (Bovtenko \& Parshukova, 2018; Chacón-Beltrán, 2017; Hemmi, Narumi-Munro, Alexander, Parker, \& Yamauch, 2013; Orsini-Jones, et al., 2015; Plump \& LaRosa, 2017). As a result, we are witnessing a rise in the number of online universities which erase geographical borders (Lee \& Im, 2014). Disappearance of geographical borders is useful both for learners and teachers: using ICT enables teachers to cooperate with their colleagues from other countries- in this way, their experience, resources, ideas and research can be shared online with other teachers internationally (Scrimshaw, 2004).

In line with this, a beneficial use of ICT in education is that students can access resources at any given time. Using technology has enabled erasing certain space and time boundaries in learning (see Bates, 2005), with students being able to access resources from anywhere in the world with a click of a mouse (Fogal, Graham, \& Lavigne, 2014), at any time, and as many times as the person wants. Thus students can be given the choice between sitting in a lecture hall of a university building or in front of their own personal computers at home. In this way students have the possibility to choose the time of receiving the content of the course: synchronously, that is at the same time as the content is delivered, or asynchronously, that is at a later point, after the content has been delivered, at a time that is appropriate for the student (Oliver \& Herrington, 2001). Having a choice puts the student in the centre of the learning process, which brings about another benefit - using multimedia as support in learning gives learners the possibility of developing autonomous learning (Beatty, 2010), which will be dealt with in detail later in this literature review. 
Even though students do not usually choose the tools they use in class, their inclination towards using ICT for social purposes could encourage their use in formal learning environments (Kim \& Park, 2018). This allows students to transfer their ICT literacy skills from a social context to a formal learning environment. However, this can be quite demanding: there has been evidence that students, despite higher levels of digital literacy, are not confident enough when using their ICT skills for academic purposes and feel that they need guidance ( $\mathrm{Ng}, 2012$; Wastiau, et al., 2013).

ICT has the potential to make teaching and learning more learner-centred (see Kukulska-Hulme, 2010; McCombs \& Vakili, 2005). In a face-to-face environment, where the teacher must teach many students at the same time, it can be rather challenging to approach each student in accordance with their needs and abilities, that is taking account of individual preferences. ICT enables students to work individually, at their own pace, and to have control over the learning process, while the teacher can be available for monitoring and giving immediate feedback online, if necessary (see Giesbers, Rienties, Tempelaar, \& Gijselaers, 2014). In this way teachers can deal with larger numbers of students via available online learning platforms - online learning platforms allow teachers to adjust their teaching to an individual student according to their level of knowledge, or provide the teacher with the possibility of giving immediate feedback to students learning online.

With technology being omnipresent in education, it has become a useful tool in language learning, too (Healey, 2016; Liu, Moore, Graham, \& Lee, 2002). Garrett (2009) discusses using technology for language learning and identifies very precisely how it has changed and developed in eighteen years (see Garrett, 1991) - from earliest available technologies (such as videos and videotaping) and their use and efficacy in supporting language learning to more recent issues related to using computers to as tools which assist in language learning (CALL). In recent years, researchers have become more aware of the importance of ICT for language learning: according to the Web of Science's citation report created upon searching the terms 'language learning' and 'ICT', since 2010 the connection between these topics has gained importance significantly - an increase in the number of publications and citations related to these two topics is visible. From the first moment when technology was integrated into second language learning, it has become obvious that computers might offer that comprehensible input needed according to SLA research. Information 
technology thus has great advantages and could be at the service of learners (Gremmo \& Riley, 1995). The influence that ICT has on language learning can be seen from the point of view of materials (resources) and classroom practice (Dudeney \& Hockly, 2012) and has brought benefits both for teachers and students (Golonka, Bowles, Frank, Richardson, \& Freynik, 2014; Kumar \& Tammelin, 2008; Mullamaa, 2010; Zhao, 2003). ICT increases accessibility to various teaching resources that can be used alongside the already existing wide range of 'authentic materials', such as newspaper articles, which can be adapted to and used in the curriculum (Gilmore, 2007; Kumar \& Tammelin, 2008; Loucky, 2010).

The fact that learners use ICT for personal purposes can be of use for language learning. Even though it cannot be confirmed to what extent using technology in informal settings influences how learners learn in formal settings (Cox, 2013), the potential that technology has for informal language learning should not be underestimated (Meyers, Erickson, \& Small, 2013; Sefton-Green, 2004). It enables learning during regular daily activities, without the direct awareness of the learners themselves. Some evidence of the benefits of technology in informal foreign language learning has been given in literature (Bytheway, 2015; Peterson, 2010; Rama, Black, van Es, \& Warschauer, 2012; Thorne, Black, \& Sykes, 2009). The examples mentioned include how playing online computer games while communicating in a foreign language with people from other parts of the world, or various types of participation in internet communities for that matter, influence language acquisition in the areas of vocabulary and communicative competence. Communicating with and interacting within the target community in the target language or conversing with native speakers of a foreign language are usually what drives people towards learning a foreign language (Kenning, 2001). Using technology presents the possibility for learners of a foreign language to link up with native speakers of the language and develop their foreign language skills as well as cross-cultural communication. Language learning and intercultural exchange can be realized through telecollaboration or online tandem learning that could simplify communication usually limited by distance (Belz, 2003; García Alonso \& Samy, 2018; Karjalainen, Pörn, Rusk, \& Björkskog, 2013; Kötter, 2003; Little, 2001; O’Dowd, 2017; Schwienhorst, 2009) and possibly develop foreign language linguistic competence and intercultural competence. 
However, using technology in education brings not only potentials, but challenges, too. Learners, who are at the centre of this learning process, often do not use ICT to its full potential or are only focused on doing what needs to be done as part of the course requirements (see Henderson, Selwyn, Neil, \& Aston, 2017; Lai \& Hong, 2014; Thang, et al., 2016; Tri \& Nguyen, 2014; Yunus, Lubis, \& Lin, 2009). Even though they use ICT in their daily lives, they are not as ready to use it for language learning voluntarily (Penner \& Grodek, 2014). This is where teachers need to step in they need to build on the students' readiness to face the challenges of coping with technological innovations (O'Dowd, 2007). This can sometimes be demanding due to teachers often being illprepared.

According to the available literature, many teachers generally still struggle with technology - the obstacles can be found in insufficient (or inadequate) training or little experience, which can both be the cause of technology avoidance in teaching (Aldunate \& Nussbaum, 2013; Hennessy, Ruthven, \& Brindley, 2005; Salehi \& Salehi, 2012). An example is a study supported by the European Commission (Cachia, Ferrari, Ala-Mutka, \& Punie, 2010), which demonstrates that teachers find ICT useful when it improves and supports creativity, but they consider 'older' technologies (e.g. computers, educational software) more important for learning than the 'newer' ones (e.g. social networks, mobile phones). This is in accordance with the data related to which tools teachers use more frequently: the tools tend to belong to traditional technologies as the teachers are more familiar with them. However, in language learning there has been research that confirms that teachers have been using 'newer' technologies for language learning, such as social media or mobile devices - being aware of their presence and importance for their learners (Akbari, Pilot, \& Simons, 2015; Brahmi, 2016; Duncan-Howell, 2010; Gallardo del Puerto \& Gamboa, 2008; Godwin-Jones, 2011; Hu \& McGrath, 2011; Peeters, 2015; Yen, Hou, \& Chang, 2015).

There is evidence that the teachers' beliefs and attitudes towards the use of technology are central to its integration and affect its usage in the classroom (Haines, 2016; Hammond, Reynolds, \& Ingram, 2011; Mumtaz, 2000; Palak \& Walls, 2009; Williams, Coles, Wilson, Richardson, \& Tuson, 2000). To interpret it in slightly different words, teachers also face challenges regarding using ICT in education - insufficient ICT skills in teaching or in using certain software, 
unsatisfactory training or lack thereof, uncertainty with regard to the possible benefits of ICT, just to name a few $(\mathrm{Fu}, 2013)$. In line with this, Lam (2000) talks about technophilia (referring to educational institutions very often acquiring new technologies without consulting teachers) and technophobia (referring to teachers who are not willing or not ready to use new developments). There is evidence that teachers who possess higher levels of ICT skills are more willing to use them to manage teaching outside the classroom walls and are more successful in doing so than their less skilled counterparts who rely on teaching in the traditional classroom (e.g. Aldunate \& Nussbaum, 2013; Thorsteinsson \& Niculescu, 2012). This implies that teachers should be trained to efficiently use technology when teaching the digital generation students and to be able to use the benefits that ICT have to offer to their full potential (Barsotti \& Martins, 2011; Dooly, 2009; Guichon \& Hauck, 2011; Mikulan, Legac, \& Siročić, 2011; Ng, 2012; Sarieva \& Zoran, 2007; Stickler \& Hampel, 2015). In addition, teacher training is crucial so that the increase in Internet-mediated intercultural foreign language education can be supported (Belz, 2003; Dooly, 2009; Lawrence, 2013; O'Dowd, 2003).

Unfortunately, ICT teacher training is sometimes perceived as unnecessary and therefore not seen as a priority by policy makers (Davies, 2002). In order for using technology in learning to be successful, teacher training is needed, or more precisely, developing skills essential for teaching in an online environment is needed (Hampel, 2009). According to the recent literature, teaching a language online is quite different from teaching it face-to-face, or when it is compared to teaching other subjects; it implies having specific skills and competences (Compton, 2009; Ernest, Heiser, \& Murphy, 2013; Guichon \& Hauck, 2011; Hampel, 2009; Hampel \& Stickler, 2005; Jauregi, De Graaff, \& van den Bergh, 2012; Kovačić, Bubaš, \& Zlatović, 2007; Southgate \& Murphy, 2011). These skills have been presented in a framework (in the shape of a pyramid) developed by Hampel and Stickler (2005) and range from using basic and specific ICT competences, dealing with the medium, to online socialization and facilitating communicative competence to finally becoming a competent and creative teacher who chooses and develops their own style of teaching by using tools at their disposal. 
Using digital tools, such as wikis or weblogs, can enhance effective instructional approaches (Warschauer, 2010) but quality planning and preparation, monitoring and moderating students' work is crucial, requiring teacher training in that area. Therefore, teachers should be familiar with methods and tools they want to use with their prospective students and should be ready to develop their technology skills in order to be able to cope with the rapid changes (Compton, 2009; Hampel \& Stickler, 2005; Jauregi, De Graaff, \& van den Bergh, 2012).

In summary, the development of ICT and the ubiquity of digital tools have influenced all spheres of our lives. However, people are divided when it comes to their effect: "Global communication networks present a paradox. They encourage alienation by reducing face-to-face contact, yet this same technology, from an opposing point of view, provides a nexus of connectivity, social interaction and community building, albeit in novel formations." (Kramsch \& Thorne, 2002:85). In the same way ICT has influenced education in general and language learning in particular by bringing about both benefits and challenges. Using technology in learning and teaching has

presented students with many options, which only confirms its far-reaching potentials. Based on these potentials, the following section will describe the role that technology can have in second language acquisition by focusing on CALL and CMC which will be described and placed in the context of this dissertation.

\subsection{Computer Assisted Language Learning (CALL) and Computer-Mediated Communication (CMC)}

Upon discussing ICT in general together with its role in education and language learning, the section that follows will focus more on computer assisted language learning (CALL) and computermediated communication (CMC) as approaches increasingly used in second language acquisition. It will begin with the definition of the term CALL and then give a brief historical overview of its developmental stages and significance it has had for language learning. The section will then focus on CMC as one of the concepts closely related to CALL. It will mention CMC tools that can be used in language teaching and learning at the same time emphasizing the usefulness of tools that were used for the study described in this dissertation. 
CALL was defined by Levy (1997:1) as "the search for and the study of applications of the computer in language teaching and learning." This definition is quite broad and encompasses all the possibilities that using computers has to offer in language teaching and learning contexts. Similar to it is the more recent definition given by Beatty (2010:7) who states that CALL is "any process in which a learner uses a computer and, as a result, improves his or her language." If we view these definitions from the point of view of theories of input and interaction, we could say that computers on the one hand can provide comprehensible input and on the other hand give students the opportunity to interact with other speakers of the second language - therefore offer the potential of improving the learner's knowledge of the second language. However, the question that arises is how can we be sure what it means to 'improve' one's language. According to Hubbard (2009:2), the answer to that question depends on the perspective: it can be looked at in relation to learning efficiency, learning effectiveness, access, convenience, motivation or institutional efficiency. For example, improving with respect to convenience means that "learners can study and practise with equal effectiveness across a wider range of times and places”.

Another definition of CALL was given by Egbert (2005:4): "CALL means learners learning language in any context with, through, and around computer technologies". She explains that the emphasis here is placed on the term context, which refers to the fact that learners learn languages not only in the formal environment of institutions, but also at home or in a café. Additionally, she points out that computer technology today does not necessarily mean desktop or laptop computers, but other devices with similar functions to those of computers (for example smartphones).

The idea behind CALL is using computers as tools for the purposes of second language learning, sometimes from different points of view (the teacher's and the learner's), which means blending two different disciplines (Sanders, 1994). In its core, CALL refers to any form of acquisition, teaching and assessment of the second language knowledge level that combines theory and pedagogy of teaching with the use of technology (Garrett, 2009). It is a complex field which presupposes the use of technology that is developing at an extremely fast pace and is therefore very dynamic and thus challenging to track (Hubbard, 2009). It shows that learners and 
teachers/researchers need to be ready to adapt to a plethora of possibilities that technologies (will) have to offer.

The field of CALL research has developed alongside the development of technology. Therefore, based on the technology that was used and how it was used, we can clearly differentiate three main stages whose timeframes were not rigid, since emergence of one stage did not mean that the previous one had stopped; on the contrary, they continued existing. These stages are as follows: behaviouristic CALL, communicative CALL, and integrative CALL (Warschauer, 1996; Warschauer, 2004; Warschauer \& Healey, 1998). According to Warschauer \& Healey, (1998), behaviouristic CALL (1950s to 1970s) is related to the behaviourist learning model (hence the name), whose focus was on language repetition activities (drill) and the computer was used as "a mechanical tutor which never grew tired or judgmental and allowed students to work at an individual pace." (ibid., p. 57). Communicative CALL (1970s and early 1980s) started at a time when computers gained some new functionalities and approaches to language learning changed fundamentally with Selinker's and Krashen's work. Therefore, the focus shifted to students not only repeating utterances, but using the forms to create original utterances in the target language, while teaching grammar explicitly. The programs at this time included text reconstructions and simulations. In this stage, interaction and output were ignored. As the authentic social contexts became of greater importance in language learning theory and new technologies were developed that allowed for communication using computers, new language learning opportunities appeared and CALL entered its third stage: integrative CALL (which began in 1990s), an approach which relies mostly on the Internet. The focus is placed on skills and technology through the use of multimedia, collaboration and interaction as this requires people to enter new discourse communities which the pre-internet era did not offer. This phase is on-going and has resulted in the emergence of new technologies which have become regular part of everyday lives. This emphasizes the importance of the teacher's interaction with students using tasks to assist them when they need help with these new genres and discourses (Warschauer, 2004).

In addition, it is worth mentioning that another term has been coined that complements Warschauer's CALL stages and it is gaining importance as a result of fast technological 
developments and their application in language learning: Intelligent Computer Assisted Language Learning or ICALL. ICALL has been in research focus for some time (see Bailin, 1995) due to an increased development of more sophisticated software that provides learners with personalized feedback and more individualized approach to the learner's results (Seljan, 2019).

Another three-stage development that was proposed by Bax (2003) also followed changes with respect to technology development and its use. He talks about restricted CALL due to restrictions that were posed by mechanical drill activities, but also limitations of hardware and programming knowledge. The second stage is open CALL - technological developments encouraged new interactions in which the computer's task was to stimulate and to guide the learner through a more creative process of language learning. The third stage is called integrated, and Bax (ibid.) agrees with Warschauer (1996) regarding most of the characteristics. It is the stage of significant developments both in the technology and its use, with focus placed on skills, interactions between learners and computer-mediated communication. The only difference is that Bax (2003) claims that this stage has not reached its implementation completely, and we should strive toward it.

The study which is the focus of this dissertation fits into this final category, be it called integrative or integrated, as it investigates the extent to which students are capable of collaboration and interaction while working together using computer-mediated communication tools with the purpose of developing vocabulary.

There has been evidence that even in the earlier technology development stage computers provided language learners with benefits, such as increased self-esteem and higher academic skills (Dunkel, 1990). With time, the focus of research has moved from the type of technology used to how it is used in teaching as a support, for example for the development of language skills, such as reading or listening (see Chun, Kern, \& Smith, 2016; Stockwell, 2007). However, this has to be planned in details so as to achieve its potentials (Azmi, 2017). Given the fact that the focus of this dissertation is placed on university level students, the potentials and benefits discussed further in the text will be the ones presented through the research that relates to that particular group. 
Chapelle (1990) emphasized that using computers could make second language acquisition easier and that using computers and CALL would open up many possibilities for the language learners. The most challenging part for teachers and researchers was understanding exactly how they could be used in the best possible way; for example, she points to the computer's consistency which could ease testing procedures for teachers. In a later paper (Chapelle, 1997), Chapelle gives examples of CALL activities and how they could be investigated by using SLA theories by taking into consideration interaction that is affected by participants (learner-learner and learner-computer) and by the goal that is trying to be achieved. However, she points out the problem of uncertainty of what learners actually do while working with CALL. Looking back to that article (Chapelle, 2016), she states that the main contribution of the article was "the suggestion that research evaluating the quality of technologies for language learning could benefit from approaches taken to investigating instructed second language acquisition" (p. 159). In a paper published in 1998, Chapelle continues with combining CALL and SLA by illustrating how SLA can be used as a starting point for designing and evaluating CALL activities used in language learning - she focuses on seven perspectives of interactionist hypothesis relevant for CALL which she uses to evaluate instructional activities. These hypotheses rely on collaboration between SLA and CALL. By providing a comprehensive analysis of how SLA could be applied to CALL in the areas of teaching by means of assessment and research, she establishes criteria which could be used to evaluate how efficient computer applications in second language acquisition are. These range from language learning potential, which refers to whether an activity is purposeful and intended for language learning or only for language use, to their practicality, which is related to the easiness of implementation of the activity (Chapelle, 2001:55). In another paper (Chapelle, 2009), she discusses SLA theoretical approaches that could be useful in CALL, such as input processing and interactionist as psycholinguistic approaches related to the use of meaningful materials and activities; and sociocultural, as an approach to language in social context that includes mediating technologies relevant for communication. She elaborates by emphasizing the difference in learners' interaction with computer and face-to-face conversation, which consequently changes linguistic input and how this affects learner's access to new forms of input (p. 750). 
Thus, today the access to technology is not an issue at least in developed countries. However, using technology effectively and in the right way continues to be challenging. Developments in digital technologies have revealed new possibilities for language learning, but they require adequate training of both teachers and learners in order for them to be used in the right way. If we look at the most cited papers in $\operatorname{ReCALL}^{3}$ - the focus has shifted from computers (PCs) to mobile phones and mobile assisted language learning, social networks, digital gaming, videoconferencing, blogs, wikis, etc. (for some see Chun, Kern, \& Smith, 2016; Cornillie, Thorne, \& Desmet, 2012; Kukulska-Hulme \& Shield, 2008; Lin, Warschauer, \& Blake, 2016; Peterson, 2010; Peterson, 2012; Reinhardt, 2017). Whichever of these tools are used, the crucial importance is that in their purpose as tools they aid language learning and enable student interaction and engagement in new ways. Therefore, it is not enough to determine only learners' level of foreign language knowledge, but also the level of their technological literacy.

It is also important that teachers become aware that teaching in the classroom and teaching by using CALL are no longer different activities. CALL is "completely complementary to almost all classroom language teaching and learning activities." (Beatty, 2010). As Motteram (2013:177) states, by using CALL teachers can "engage in activity that supports language development in more profound ways than has hitherto been realised". The Internet has opened up many possibilities which have affected language learning, and its affordances for communication have enabled interaction between learners internationally through projects and task-based activities focusing on the importance of interculturalism. Also, access to authentic resources (for example, online newspaper articles that can be used for reading and comprehension) has become easier than ever and websites offer resource materials prepared for the classroom (for example, BBC Learning English). Discussion groups became a common tool for teachers where they could share their learning experiences and suggestions; Web 2.0 tools which do not require special programming skills have become useful for teachers in creating online materials (Dudeney \& Hockly, 2012).

\footnotetext{
${ }^{3}$ ReCALL is the journal of the European Association for Computer Assisted Language Learning (EUROCALL). It seeks to fulfil the stated aims of EUROCALL as a whole, and more particularly to promote the use of foreign languages within Europe and beyond, providing an international focus for the promulgation of innovative research in the area of computer-assisted language learning and technology-enhanced language learning in education and training. (https://www.cambridge.org/core/journals/recall)
} 
Consequently, rapid technology development has led to an era where it becomes possible to use other devices besides conventional computers and to learn the language in less formal environments, without the direct presence of teachers, through using mobile phones, social networks, or online games. This can be of great importance for the area of learner autonomy since learning has moved away from the classroom - something that will be picked up below in section 3.5.

In line with the previous paragraph that discussed rapid technology development and how it affects language learning and communication in general, another concept closely related to CALL that has been mentioned earlier will be discussed: computer-mediated communication. Its role in language learning and its significance for this dissertation will be analysed in the following paragraphs.

These days, when technology has become an almost irreplaceable part of our lives, we have witnessed speedy developments in digital technology. This has affected many fields, including communication. The appearance of CMC tools such as blogs, e-mail, chats, etc., not only enabled communication using computers, but also gave people the possibility to communicate without being limited by where they were located. CMC tools have been used in education in collaborative environments (see Wolz, et al., 1997), which made them very useful when learning a language. As an approach which is frequently used in language learning, CMC has shown to be closely related to previously described CALL. This close relationship of CMC and CALL has become the separate subject of research interest found in the literature based on meta-studies until 2006 (Lamy and Hampel, 2007). Since these two dominating concepts have been used alongside other ones mentioned earlier in the chapter to "cover learning and teaching with and communicating through computers", Lamy and Hampel (2007:7) use the acronym CMCL to encompass both CALL and $\mathrm{CMC}$; therefore, computer-mediated communication for language learning and teaching. However, in this dissertation, they will be used separately.

Luppicini (2007:142) describes CMC as "as communications, mediated by interconnected computers, between individuals or groups separated in space and/or time." CMC means communicating using the computer regardless of the boundaries of space and time. The story of CMC began with e-mails and today it has moved beyond it (Hiltz \& Turoff, 1994). It includes, but 
is not limited to, communication via e-mail, chat, forums, social networks, online games, and many other types of communication realized through the use of computers. CMC tools differ in whether they are used as asynchronous (delayed) or synchronous (real time) communication. To be more precise, according to Beatty (2010:70), "asynchronous refers to communication that takes place at different times, for example, through email in which a message is sent and may be read at leisure by the recipient. Synchronous refers to communication that takes place at the same time, such as through chatlines."

CMC has enabled "a truly interactive environment $[\ldots]$ with the possibility of using the computer to exchange not only text but also audio and video via the Internet." (Blake, 2009:823). This has encouraged teachers to explore combining authentic materials, which could easily be found online, with regular teaching methods and models in the classroom; therefore, the online/virtual classroom and the regular/brick-and-mortar classroom could be combined for the purpose of creating a better learning experience. Therefore, we can talk about $\mathrm{CMC}$ as a tool, but also as a creative process of language development (Thorne \& Payne, 2005).

There has been a significant amount of research conducted on CMC and language education (for some see Blake, 2011; Deutschmann \& Vu, 2015; Goertler, 2009; Hosseini, 2015; Johnson, 2006; Kenning, 2010; Lin, 2015; Luppicini, 2007; Nguyen, 2008; Thorne \& Payne, 2005; Warschauer, 2010; Watts, 2016; Ziegler, 2016; Hampel, 2014). While it has shown that CMC is an area that is evolving constantly and that it can be used instead, or alongside of, the traditional classroom due to its benefits for learners (van Compernolle, 2017), it has also been concluded that additional research needs to be conducted in the area of integrating the use of CMC in formal language education. Spitzberg (2011) conducted a study focusing on learner competence in terms of computer-mediated communication using self-assessment conducted at two points of research. He found that while most of the constructs he used in his model (knowledge, coordination, attentiveness, expressiveness, composure, and adaptability) showed an increase in self-assessment, motivation and efficacy did not. Another relevant notion for this research is Spitzberg's (2006) finding that face-to-face interaction and $\mathrm{CMC}$ interaction show more similarities than differences. Even when the context of learning is changed, learning can still occur. The more competent the 
students are using technology, the easier it is for them to concentrate on other aspects that relate to their learning. Using blended learning environments presupposes that learners have the appropriate technology skills to follow the course. Spitzberg developed a model of CMC competence which has been used in various research areas (for detailed insights see Bunz \& Montez, 2015). This dissertation is an attempt to contribute to the research in the area of using a blended learning approach to language learning.

Even though there are a substantial number of CMC tools available (blogs, chats, e-mail, etc.), for the purposes of this dissertation, we will focus only on wikis as one of the tools included in the study. This does not mean that the others are less efficient in the context of language learning. Wikis have been present in the online world since 1995, when the creator of the term, Ward Cunningham, used the Hawaiian word meaning 'fast, quick' to name the concept that represents “a freely expandable collection of interlinked Web 'pages', a hypertext system for storing and modifying information - a database, where each page is easily editable by any user with a formscapable Web browser client." (Leuf \& Cunningham, 2001:14). In simple words, a wiki is a website which allows its users to add, create and edit content, using text or other media forms; it is easily accessible and anyone with internet connection can participate and collaborate. Lund (2008:41) compares wikis and other online, distributed environments such as e.g. Learning Management Systems (LMS) and groupware applications and states that wikis are different because of their open architecture. Using or creating a wiki does not require great technical skills, and this makes it a perfect tool for both teachers and students. Both LMSs and their applicability in language learning will be described in details in the section to follow; in this section, the focus is only on them as $\mathrm{CMC}$ tools that are available in higher education and used as a tool in the study described later in this dissertation.

Lund (2008), in addition to addressing relevant research, describes a case study in which high school students worked on a wiki with the topic of the USA. The feedback was very positive and the study showed that wikis encourage collaboration. In the literature, there is other research related to wikis in higher education (e.g. Bobera, Sakal, Tumbas and Matković, 2014; Cilliers, 2016; Chu, et al., 2017; de Almeida Mello, 2017; Goertler, 2009; Miyazoe \& Anderson, 2010; Papadima- 
Sophocleous, 2012; Vurdien, 2017; Wang, Zou, Wang, \& Xing, 2013) and the conclusions are quite similar: it is a technology that is simple to use, and by using, and especially by creating wikis, students have the chance to develop their technology skills and improve their language, especially with regard to writing skills. At the same time, the differences between less and more proficient learners are less visible. This is one of the reasons why the study described in this dissertation investigates and discusses the use of wikis, to find out whether development of skills and language improvement are possible.

The other type of tool that is used in the study described in this dissertation is a glossary within Moodle (an open source learning platform, or Learning Management System). The glossary allows for activities which give students an opportunity to create their own lists of words with the purpose of acquiring vocabulary. According to research, glossaries are perceived as being of educational use, but at the same time they can be quite challenging as an activity which requires students' dedication and time and sometimes an additional incentive and support by the teacher (Breeze, 2014; Hirschel, 2012; Ratz, 2016; Stanley, 2007).

Both wikis and glossary are used in this study in the context of activities that can be easily used by students and monitored by the teacher, with minimal teacher intervention. In addition, due to the collaborative nature of these activities, students are encouraged to individually contribute to the task which in the end creates a whole unit that can be used and referred to whenever the students have the need for it. These particular features make wikis and glossaries a very fruitful basis for vocabulary acquisition at tertiary education institutions. For these reasons, wikis and glossary have been chosen as the tools used in the study. Their usefulness and how they were approached in the study will be described in the chapter dedicated to the methodology used for the study, Chapter 5.

The aim of this section was to give an overview of the literature that provides a robust foundation for the present study, focusing on the area of CALL and CMC research as approaches to language teaching and learning when using technology in the classroom. The literature has shown that language learning can be supported by various CMC tools that students and teachers may have at their disposal. The usefulness of these tools can be easily visible in a blended learning environment. 
Therefore, the aim of the following section is to give a literature review of blended learning in general together with the affordances it possesses for students and teachers.

\subsection{Blended Learning}

In the previous sections we discussed ICT, CALL, CMC and looked at their use in the context of, and for, the purpose of second language acquisition. We discussed the benefits that digital technologies offer and we discussed interaction that is realised in online communication. Mainstream technology devices have moved the classroom from buildings to online environments, and e-learning has become a regular mode of teaching delivery. Garrison (2011:2) defines elearning as "electronically mediated asynchronous and synchronous communication for the purpose of constructing and confirming knowledge." E-learning tends to have two primary instantiations: online learning and blended learning. The latter will be discussed in this section which is going to deal with blended learning as one of the approaches to teaching and learning at higher education institutions, with special emphasis put on second language acquisition (see Klasnić, Lasić-Lazić, Seljan, 2010). It will start with a general overview of blended learning research and then continue with defining the term and describe an ideal blended learning environment. Next, it will address students' attitudes towards blended learning. The section will conclude with the role blended learning has in comparison with face-to-face learning.

According to an analysis of research carried out by the U.S. Department of Education (Drysdale, Graham, Spring, \& Halverson, 2013), and a more recent analysis of the literature on blended learning conducted by Spring \& Graham (2017), blended learning at primary, secondary, tertiary educational or corporate level has been a topic of increasing interest of many researchers for the past ten years. Drysdale, Graham, Spring, \& Halverson (2013) scrutinized 205 master's theses and doctoral dissertations and studied demographic, methodological and topical trends. Based on these dissertations, it can be seen that research on blended learning has increased steadily since 2001. Here are some of their conclusions with regard to demographic, methodological and topical trends:

- the majority of the studies were conducted in higher education contexts; 
- more than $80 \%$ of them were focused on course-level blends while only three per cent studied activity-level blending;

- techniques used for data analysis were inferential statistics, a combined method of both inferential statistics and qualitative analysis followed by quantitative analysis;

- the most popular research topic addressed learner outcomes, with performance outcomes as the sub-topic, which could be supported with sub-topics of student engagement, motivation and satisfaction in the future research;

- $\quad$ the majority of students preferred blended classes to traditional face-to-face classes;

- one third was dealing with instructional design and the authors noted that it would be beneficial to study subtopics such as implementation, evaluation and environment;

- almost one third addressed interaction in some manner, but there is a gap as no studies focused on learner-content interaction;

- more than one in five compared blended to face-to-face or online learning, but the authors recommend more research be done in the area of technology and how technology can be used within a blended environment;

- with respect to the theoretical framework used, the authors conclude that the studies lacked theoretical grounds and thus they perceive the need for more theoretical contexts unique to the context of blended learning.

Halverson, Graham, Spring, Drysdale, \& Henrie (2014) and Spring \& Graham (2017) came to very similar conclusions regarding the blended learning topics, research and publication by analysing the most cited papers and book chapters.

What all of these papers have shown is that the interest in blended learning has increased with time. Before going into any details with regard to specific literature review, it is necessary to define the term blended learning and emphasize what is being blended in the study discussed in this dissertation. 
The term 'blended learning' itself is not new - it has been a 'buzz word in language teaching' for more than twenty years (Sharma, 2010:456). It means bringing together traditional modes of learning and teaching with the use of ICT. It represents an approach that can be used in both academic and corporate environments for the purpose of tailoring the content delivery to the preferences and needs of an individual, thereby integrating "the innovative and technological advances offered by online learning with the interaction and participation offered in the best of traditional learning." (Thorne, 2003:16).

The definitions of the term 'blended learning' found in the literature (Čonkova, 2013; Duhaney, 2004; Garrison and Kanuka, 2004; Garrison \& Vaughan, 2008; Graham, 2006; Nicolson, Murphy, \& Southgate, 2011; Sharma and Barret, 2007) mainly differ in terms of what is blended. Modes of delivery or didactic methods can be blended; they represent the various content delivery media, that is, devices used to deliver the instructional message, such as computer screens or projectors (Mayer, 2009) and the influence they have on learning. Graham, Allen \& Ure (2005:253) call these instructional modalities. Then, we can blend instructional methods, that is the process that enables instruction using different instructional strategies, such as collaborative learning or a lecture. The focus here is placed on the influence that learning methods have on learning (Kanuka, 2011). In addition to what is blended, there is a difference in who is responsible for the blending - whether it is corporations or language teachers at higher-education institutions (Garrison \& Kanuka, 2004; Thorne, 2003). Oliver and Trigwell (2005) emphasise that the term blended learning refers only to learning and not to teaching and therefore suggest that it is not used in the best possible way since it does not recognize the difference between teaching and learning. They claim that blended learning is not adequately defined by and not properly used in any of the definitions "because [the term] simply describes practice within higher education more generally, and it attributes to learning something that, in terms of what we know, only applies to teaching or instruction" (p. 24). They continue that it lacks the learner's perspective. Therefore, it could be argued that their claim does not 'reject' the definitions they discuss in their article, but it emphasizes the importance of the learner's experience. 
In this dissertation, the term will be defined as an integrated and efficient combination or blend of online and face-to-face learning whose proportions can vary. The definition is in accordance with the ones used by the previously mentioned authors and is the closest to the one given by Graham (2006:5). It encompasses the blend of two separate models of teaching and learning - face-to-face and computer-mediated. This combination comprises the traditional setting of teacher and student being located in the classroom and self-study (students working on their own, e.g. carrying out a search on the Internet with an educational purpose) and/or collaborative learning using an elearning platform (students working online and collaborating within a group, e.g. to construct a wiki), creating a potentially rich blended learning environment.

In an ideal blended learning environment, one where students have the opportunity to collaborate, receive feedback in a context free of anxiety, choose their place of learning, have flexible learning hours, participate in learning tailored to their individual needs, and to surpass geographic limitations, the learner is at the centre of the blended learning process and the teacher's task is to be actively involved as a task creator, moderator, and supervisor who has to be ready to give feedback to the students when and as needed; therefore, the teacher functions as a designer and facilitator (Garrison \& Vaughan, 2008; Norberg, Dziuban, \& Moskal, 2011). This makes the teacher's role challenging in that he or she has to achieve the right balance between online learning and face-to-face learning. Moreover, they have to fill the gap that appears with the lack of face-toface communication with regard to the teacher's role (Fučkan Držić, 2009; Seljan, Banek, Špiranec, \& Lasić-Lazić, 2006). Even in online and distance settings the teacher's role in promoting interactive communication is irreplaceable.

Thus, the perfect blend of face-to-face and online teaching and learning, and the successful implementation of it, very much depends on the teacher (see Neumeier, 2005) since blended learning usually does not refer to an entire institution but only a course. Nevertheless, according to VanDerLinden (2014), institutions have a significant role - their efforts should also be directed towards enabling and offering support to their course creators and teaching staff regarding appropriate pedagogical approaches to blended learning. Indeed, many universities have already adopted blended learning as a regular way of teaching. According to Garrison and Vaughn 
(2008:152), blended learning "has become contagious because it addresses the quality of the educational experience in higher education as well as the use of technology to enhance the ideals of traditional higher education". The process of transition from an awareness of blended learning to its implementation has not been easy for some higher education institutions since it is challenging to find the best possible way to implement it (see Buran \& Evseeva, 2015; Porter, Graham, Spring, \& Welch, 2014; Wold, 2013).

There is evidence in the literature that blended learning is exactly what is needed by learners who grow up with technology as it represents a development of "new spaces and places for interaction...beyond the conventional classroom." (Monteiro, Leite, \& Lima, 2013:109). Newer generations of students rely on technology to a great extent and are ready to use it in the classroom, whatever form this classroom takes. The attitudes that students have towards blended learning are usually positive: the results have shown that students' satisfaction is higher when they learn using a blended approach (Bañados, 2006; Bueno-Alastuey \& López Pérez, 2014; Oliver 2005; Rahman, Hussein, \& Aluwi, 2015; Spanjers, et al., 2015; Şahin-Kız1l, 2014; Woltering, Herrler, Spitzer, \& Spreckelsen, 2009).

On the other hand, the effectiveness of blended learning is similar to the effectiveness of face-toface learning. Means, Toyama, Murphy, \& Baki (2013) have conducted a meta-analysis of the empirical literature focusing on the effectiveness of online and blended learning by comparing learning outcomes of fully online or blended learning with those of face-to-face learning. Based on the statistical synthesis results of the studies, they concluded that online learning conditions slightly improved students' performance. This advantage over face-to-face classes was significant when contrasting face-to-face with blended learning, and not as much when contrasting it with solely online conditions; they concluded that there is no significant difference in student performance between face-to-face and online delivery modes. According to their conclusions, what is important is not the use of the Internet, but how these online activities are treated. Other research has shown that the delivery mode may not be a major factor in student performance (Larson \& Sung, 2009; Lim, Morris, \& Kupritz, 2007). Additionally, Kwak, Menezes and Sherwood (2015) found that student performance is negatively affected by blended learning if learning is cumulative (semester- 
length course). That is why special care needs to be taken when designing a course to adapt it to learners' needs, but also to take into consideration teachers and activities performed during the course (Hampel \& Pleines, 2013). One of the means that enable the realization of blended environments are learning management systems (LMS) that could be completely adapted to learners, teachers, and the choice of activities; they will be discussed in the following paragraphs.

\subsubsection{Learning Management Systems}

Previously in the section blended learning was discussed as one of the approaches to teaching and learning at higher education institutions, and how it can be a fruitful context for language improvement. After providing a general overview of blended learning research and defining the term, an ideal blended learning environment was described. This was followed by addressing students' attitudes towards blended learning and was concluded by comparing the role of blended and face-to-face learning. Closely related to a blended learning environment are Learning Management Systems (LMS); therefore, the following paragraphs of this sub-section will describe what an LMS is, with special emphasis placed on Moodle, a learning platform used in the study described in Chapter 4.

Learning Management System or LMS (sometimes used interchangeably with the term Virtual Learning Environment or $\mathrm{VLE}^{4}$ ) is an e-learning platform (Graf \& List, 2005). The term is currently used to describe a number of different educational computer applications (Watson \& Watson, 2007). Their popularity in tertiary education is on the rise; using LMSs has become a regular addition to the websites that universities use in Croatia, and students use it mostly prior to exams to consult the teaching materials uploaded for them by the teacher during the academic year (Kadoić \& Oreški, 2018; Korljan \& Škvorc, 2009). An LMS is mostly used as a component of elearning, as an additional tool for teachers to make their materials available to students (ElMowafy, Kuhn, \& Snow, 2013). However, an LMS has other functions which have the potential to enrich learning: they do not only make course materials available to students at any time but

\footnotetext{
4 The LMS in question (Moodle) is sometimes categorized as an LMS, sometimes as a VLE. For a very short, concise and clear explanation of the distinction see Pinner, R. (2014). What Is the Difference Between an LMS and a VLE? Available on https://elearningindustry.com/difference-between-lms-and-vle
} 
offer other options such as forums, wikis, glossaries, etc., which also support interactivity and collaboration between learners (Agosto, Copeland, \& Zach, 2013).

One such system is Moodle, used at the university at the centre of this study. According to the Moodle website, it is a learning platform designed to provide educators, administrators and learners with a single robust, secure and integrated system to create personalised learning environments. Its development is based on social constructionist pedagogy, which means that interaction is central. In line with that, it provides learners and teachers with tools and collaborative environments that put the learner at the centre of the learning process. It is free Open Source software, which means it can be edited and modified for whatever purpose. It is easy to use because of its simple interface. It supports both blended learning and online courses by including external collaborative tools such as forums, wikis, chats and blogs. All of these features make it an ideal environment to encourage CMC use in teaching (Ageel \& Woollard, 2012) and help students develop CMC competence. Other benefits range from increasing motivation to improving language and fostering learner autonomy (Gulbinskienè, Masoodi, \& Šliogerienè, 2017; Huang, Chen, \& Chen, 2009; Lopes, 2011; Sumtsova, et al., 2018; Stickler \& Hampel, 2010). Students who use Moodle, regardless of their study area, generally have a positive attitude towards its usefulness and their satisfaction usually depends on how the course is organized (Cassidy, 2016; Damnjanovic, Jednak, \& Mijatovic, 2015; Gundu \& Ozcan, 2017; Xu \& Mahenthiran, 2016; Yeou, 2016).

Moodle is an environment where a teacher can upload teaching materials and set up activities for students (Bošković, Gajić, \& Tomić. 2014). The course page is easy to manage since it consists of sections which contain the tasks whose completion can be easily checked. The teacher has the role of administrator and can therefore perform functions such as text editing, assigning activities, adding resources, asking and answering questions, and grading student work.

There are 14 different types of activities in a standard Moodle site (but not all of them have to be used):

- Assignments (enable teachers to grade and give comments on uploaded files and assignments created on and off line), 
- Chat (allows participants to have a real-time synchronous discussion),

- Choice (a teacher asks a question and specifies a choice of multiple responses),

- Database (enables participants to create, maintain and search a bank of record entries),

- Feedback (for creating and conducting surveys to collect feedback),

- Forum (allows participants to have asynchronous discussions),

- Glossary (enables participants to create and maintain a list of definitions, like a dictionary),

- Lesson (for delivering content in flexible ways),

- (LTI) External tool (allows participants to interact with LTI compliant learning resources and activities on other web sites),

- Quiz (allows the teacher to design and set quiz tests, which may be automatically marked and feedback and/or to correct answers shown),

- SCORM (enables SCORM packages to be included as course content),

- Survey (for gathering data from students to help teachers learn about their class and reflect on their own teaching),

- Wiki (a collection of web pages that anyone can add to or edit),

- Workshop (enables peer assessment).

In the context of interaction, Moodle offers different activities which students can do and contribute to in order to interact either with their peers or the teacher. If we take the example of the course designed and presented by Hampel \& Pleines (2013), we see that interaction is supported when students create or add content to collaborative activities such as wikis or glossary in accordance with the task set and input given by the teacher; and the students are encouraged to create output that can be used by other students as input to aid and improve their language learning. The teacher's or the course creator's (challenging) task is to carefully design and adapt the course as required by 
the learners' needs and preferences in order to organize learning activities so as to achieve its maximum potential. Therefore, possibilities of LMS are manifold.

To sum up, a blended learning approach that brings together face-to-face classroom learning with the possibilities offered by an LMS can be a useful tool in the context of promoting students' second language acquisition. Its benefits can be used for different purposes and the question that this study is trying to answer is how effective a blended learning approach is when used in vocabulary acquisition and learner autonomy. At the same time, we have to bear in mind that vocabulary acquisition associated with computer-mediated interaction tends to provide benefits for learners, but when compared with face-to-face interaction, it is not as effective (Fuente, 2003). The following section will therefore try to discuss vocabulary development and see what possibilities learners and teachers have at their disposal when learning or teaching vocabulary.

\subsection{Vocabulary Development}

This section of the dissertation will address the importance of vocabulary for second language acquisition in general and the role that blended learning can have in it. Special emphasis will be placed on English for Specific Purposes as the subject in focus of this dissertation. The section will provide an insight into the most important and recent literature in this area.

According to the online Oxford Learner's Dictionary', the word 'vocabulary' has four meanings: 1) all the words that a person knows or uses, 2) all the words in a particular language, 3) the words that people use when they are talking about a particular subject, and 4) a list of words with their meanings, especially in a book for learning a foreign language. All of these definitions are relevant in this dissertation because all of them are applicable. The point of giving these definitions lies in their common underlying meaning: vocabulary is important, if not crucial for understanding a language; it is the crucial substance of a language and of communication. If you want to communicate in a particular language, you need to know 'the words'. "Without grammar very little can be conveyed, without vocabulary nothing can be conveyed." (Wilkins in Schmitt, 2010).

\footnotetext{
${ }^{5} \mathrm{https}: / /$ www.oxfordlearnersdictionaries.com/definition/english/vocabulary?q=vocabulary
} 
In second language acquisition, the importance of vocabulary was not recognized as a useful SLA research area for a long time, which was to the detriment of the discipline. Researchers were more focused on other areas such as syntax and phonology (Zimermann, 1996), and when the focus was on vocabulary, it was mostly on vocabulary teaching, not learning (Meara, 1980). Nevertheless, times have changed. Krashen's notion of second language acquisition opened up many possibilities for research in this area by understanding language as a creative process and a challenging task. In order to communicate successfully and effectively in any language, it is necessary to be able to understand as well as actively use significant numbers of words, that is, be efficient on the receptive and the productive level (Krashen, 1982; Schmitt, 2000). Schmitt (2010) mentions a number of studies which have shown high correlations between vocabulary knowledge and language proficiency. They have shown that the proficiency level increases with vocabulary acquisition, which consequently implies that an extensive vocabulary allows the learner to develop other skills.

In order to understand vocabulary and what importance it assumes for second language acquisition or when designing a study focusing on vocabulary, it is necessary to take into consideration ten key issues related to vocabulary as outlined by Schmitt (2010):

- vocabulary is an important component of language use,

- a large vocabulary is required for language use,

- formulaic language is as important as individual words,

- corpus analysis is an important research tool,

- vocabulary knowledge is a rich and complex construct,

- vocabulary learning is incremental in nature,

- vocabulary attrition and long-term retention,

- vocabulary form is important,

- recognizing the importance of the L1 in vocabulary studies, 
- engagement is a critical factor in vocabulary acquisition.

Not all of these key issues are taken into consideration in this dissertation because this would surpass its scope. Nevertheless, some of them will be referred to in the following paragraphs.

Based on the studies he investigated, Milton (2013:75) comes to the conclusion that the development of learners' vocabulary knowledge is crucial for their general language performance, whether we talk about grammatical development or overall language ability. If we want to relate this to the theories of input and interaction, we could say that the larger a learner's vocabulary is, the more they can comprehend the input, the more the input transforms into intake, and consequently can be used as output. Basically, the more words a learner knows, the more of a language they will learn. This is closely related to the issue mentioned at the beginning of the chapter, that is that vocabulary learning increases gradually, both in the first and the second language.

With respect to how much vocabulary one needs to know to use another language, Nation (2001) comforts all second language learners by saying that achieving the level of proficiency that native speakers have should be a long-term goal. The short-term goal should be learning those words which are more useful than others, those which are sufficient for normal functioning in the second language environment. Using a short academic text as an example, he distinguishes four categories of vocabulary. High frequency words, which make up almost $80 \%$ of the text, include function words (such as 'in', or prepositions) and content words (such as 'government', or nouns that can appear on a daily basis in the learner's environment). Academic words (9\%) are words common in academic texts (such as 'phase') and are important for users of English for academic purposes. Technical words (5\%) make up the third category - words common in and closely related to the topic and subject area of the text (such as 'sterntube'); they are different in every subject area and can be found in specialised dictionaries. The fourth category is the category of low frequency words (5\%), which make up the biggest group and include all the words which do not belong to any of the previously mentioned categories for a particular subject (such as 'perpetuity'). 
Technical language is the focus of this study, and it is understood as being taught and learned as a type of vocabulary within the context of English for specific purposes. This is supported by Hutchinson \& Waters (1987:17), who describe it as a subcategory of language for specific purposes. In this dissertation, vocabulary refers to technical words which are relevant in the context of ESP in general and in the context of engineering in particular (including civil engineering, electrical engineering, mechanical engineering, logistics, multimedia). We can recognize technical words based on their unique form and meaning (for example, in the field of mechanical engineering this could be the word 'abrasive') and it takes knowledge of the field to be able to use them (Nation, 2001:27; Chung \& Nation, 2004). Vocabulary acquisition in relation to ESP is crucial - especially in relation to content words which are the words that carry the meaning; without them, it is impossible to communicate in a foreign language.

In order to acquire a second language, learners need to be exposed to it and very often immersed in it. The more they are exposed, the larger is the input and learning is more successful. Schmitt (2010:28) claims that even exposure to testing lexical items facilitates better retention. Therefore, teachers should promote what he calls engagement, that is any kind of activity that leads to active involvement of the learner. An example of such an activity could be looking up unfamiliar words in an online dictionary using a smartphone during a reading activity (for some examples see Alharbi, 2016; Chen, 2012; Fuertes-Olivera, 2018) and therefore interactively involving the learner in input modification such as paraphrasing specific words (see Huckin \& Coady, 1999). In this way, students can use their technology skills and the knowledge of the topic to find the proper description or translation of the word needed for comprehension of the text, especially when the text in question is closely related to the specific topic of interest, e.g. engineering. In some situations, this works well, with students trying to guess the meaning of a word by looking at its form and using their knowledge of the first language. However, it can also misguide the learner and output errors occur, which can be expected if the learner is not familiar with the subject of their reading or did not acquire the core vocabulary. Nevertheless, there are studies that have shown that L1 helps in vocabulary acquisition and L1 has a facilitative role in general English (Goundareva, 2011; Liu, 2008; Pakzadian, 2012) and in ESP (Kavaliauskienë, 2009; Kavaliauskienë \& Kaminskiene, 2007; Garcia, 2018). 
Even though using technology for teaching new vocabulary can be very efficient (Allum, 2004), there are some differences. Brahja (2013) studied the potential relation between ESP vocabulary teaching by the language teacher and ESP learning on the Internet and her results were intriguing: even though students consider both environments interesting, they find it more motivating when learning ESP with a teacher. They felt more independent when learning online. If we as teachers manage to help learners become autonomous in the process of learning ESP, we could say we have prepared a person to face the challenges of life-long learning and the real world.

A study conducted by Chiu (2013) shows that L2 vocabulary learning is more successful when the teacher is not present. The possible explanation that is given is that CALL vocabulary programs can provide for individual learning styles and pace, which allow for autonomous learning. This is also the case with LMSs, which evidently show that vocabulary can be fostered using the affordances of technology, without strictly requiring the face-to-face interaction (García-Sánchez, 2016; Ratz, 2016). Even though ESP context is a taught context, we cannot dismiss the possibility that vocabulary can be acquired when doing extensive reading about a familiar content and relying on familiar foreign vocabulary items can help in guessing the meaning of other unknown words and therefore acquiring new vocabulary (see Ahmad, 2012; Hunt \& Beglar, 2002; Nation, 2015). There are occasions when learners are not aware of their learning - in this case, we talk about incidental learning. This refers to learning without the intended purpose of learning, such as learning vocabulary while reading as part of a leisure activity on a topic of interest (Laufer \& Hulstijn, 2001; Dam \& Legenhausen, 2001; Khoii \& Ashuri, 2016). Huckin and Coady (1999) presented a literature review on incidental learning which has shown that even though explicit vocabulary instruction in conjunction with extensive reading is beneficial for students, incidental learning can be useful for fostering vocabulary. It can be supported by doing extensive reading of texts which learners are personally interested in. However, Huckin and Coady (1999) were not able to find an answer to the question of how many times a learner has to be exposed to a word to retain it. More recent literature confirms previous findings that the higher the exposure to the language and repetition of the words, the higher the retention (Alali \& Schmitt, 2012; Pellicer-Sánchez, 2016; Restrepo Ramos, 2015; Vidal, 2011). 
Incidental vocabulary learning has been noted to happen while using technology, too. Lin (2010) conducted a study with news video in a CALL program and the results obtained showed that both proficient and less-proficient groups made significant progress in incidental vocabulary acquisition. Peters and Webb (2018) reported on two experiments whose task was to investigate incidental vocabulary acquisition through watching a TV program and the results suggest that incidental acquisition can occur. McGraw, Yoshimoto, \& Seneff (2009) presented a study which investigated incidental vocabulary acquisition through using a speech technology interactive card game and the results speak in favour of incidental vocabulary acquisition. Thus, by using advances in technology, learners can be supported in their vocabulary acquisition in a blended learning environment. This has been taken into consideration while conducting the study and researching students' vocabulary and will be described in Chapter 5.

In order to be sure that the results of investigating vocabulary development are reliable and valid, the methodology used should be adequately chosen depending on the information and data that are looked for. Schmitt (2009), as a recognized vocabulary researcher, discussed the topic of vocabulary research in details. There are various instruments and tools available: from the vocabulary size test (which measures a learner's receptive vocabulary size from the first 1,000 to the fourteenth 1,000 word families of English) and vocabulary levels test to analysing particular corpora representing various types of English (general, spoken, academic, etc.) and using concordancers. Which one of these to use depends on what we want to investigate. Schmitt even provided several possible topics that could be researched in the field of vocabulary acquisition (he calls them projects) together with possible goals, methodology and questions to consider. In this dissertation, Vocabulary Levels Test (Laufer \& Nation, 1999) was used with the purpose of checking the vocabulary necessary for understanding the basic 1000 words in the English language as evidence that even those students who had never learned English in a formal environment would be able to understand English to a certain extent. Its use and how it was combined with a test created by the teacher will be described in details in the chapter dedicated to methodology.

This section reviewed the relevance of vocabulary, how it is studied in SLA and how learners develop it in the context of second language acquisition. Vocabulary is one of the most important 
areas in language learning since its development can help in developing the four skills and communication in general (Nation, 1994). In addition, the purpose of the chapter has been to enhance the understanding of the concept of vocabulary through the literature to illustrate how it relates to this study. As the literature has shown, vocabulary learning can be acquired purposefully or incidentally, and this can be used in different learning environments. The possible differences in the process of vocabulary development in an ESP context in two different learning environments (face-to-face and blended) at tertiary level are going to be described and discussed in the Results and Discussion chapters below. LMS Moodle, its activities wiki and glossary in particular, will be one of the tools that is used in this study in the process of vocabulary development, with Moodle being a tool which closely relates to the development of learner autonomy. This concept will be discussed in details in the following section.

\subsection{Learner Autonomy Development}

The beginning of this section will give an overview of the literature regarding the concept of learner autonomy and some other concepts related to it. Then, it will focus on the significance it has for learners using a blended approach to foreign language learning at tertiary level (students). Additionally, it will look at learner autonomy through the framework of second language acquisition (SLA) theories. The section will be concluded by reviewing the areas of developing and fostering learner autonomy as presented in the literature.

The concept of learner autonomy has been present in philosophy and psychology since the late 1960s. According to Gremmo \& Riley (1995), the concept emerged as a result of the changes in society that led towards an individual-centred learning. It was often used in combination with closely related terms such as self-centred learning, self-directed learning, self-access, individualization, and (learner) independence. It is a concept which attracts the attention of many scholars due to its importance in today's technological environments and in the context of life-long learning.

Learner autonomy became an idea worth investigating in the context of the language learning classroom when communication started to be perceived as a dynamic process and language as a social practice (Adamson, 2004). It has been a topic of interest in foreign language learning for 
around 40 years, as recorded by Benson (2013) and Smith (2008) among others. Richard Smith, aware of its importance for language learning, coordinated the DAHLA ${ }^{6}$ (Developing an Archive and Histories of Learner Autonomy) project which was launched at the Nordic Workshop on Learner Autonomy in the Foreign Language Classroom, Copenhagen. The purpose of the project was to create an archive of publications which would offer insights into the most significant literature published on learner autonomy in one place.

According to Benson (2013), the concept of learner autonomy was first introduced in language teaching through the setting up of the self-access centre Centre de Recherches et d'Applications en Langues (CRAPEL) ${ }^{7}$ at the University of Nancy, France, by Yves Châlon. Upon his early death, the person in charge of the centre became Henri Holec. He was the first one to use the term in the specific context of adult education and language learning in a report dating from 1979. The report was published as an outcome of the Council of Europe's Modern Languages Project. In it, Holec describes autonomy as the learner's ability to take charge of their own learning; however, since this ability is not innate, there has to be some systematic and purposeful learning involved (Holec, 1979:3). He continues by describing an autonomous learner as a learner who is responsible for and controls decisions related to the process of learning without being directly independent on the teacher (ibid.:4). At the same time, the teacher's task is to guide the learner towards autonomy. Therefore, an autonomous learner can choose what and how to learn, but is responsible for the task. At the same time the learner learns a language and learns how to learn.

Even though Holec's definition of autonomy as an ability has been used by many authors (for some see Benson, 1997; Benson, 2007; Gardner, 2011; Raya \& Vieira, 2015; Little, 1991; Littlewood, 1996; Nunan, 1997), there are also other - often similar - terms such as capacity, potential, responsibility, awareness, choice, willingness, or attitudes. This multitude of terms that have been used in the context of autonomy confirm that defining autonomy is not as simple as it might seem since different researchers use it differently.

\footnotetext{
${ }^{6}$ https://warwick.ac.uk/fac/soc/al/research/groups/llta/research/past_projects/dahla/

7 "In the interests of widening access to education and promoting lifelong learning, CRAPEL began to offer adults the opportunity to learn a foreign language in a resources centre, free from teacher direction.” (Smith, 2008:395)
} 
Little (2003) explained the problems around providing a simple and precise definition of autonomy as a consequence of its complexity. According to him, even though debates related to autonomy exist (such as whether learner autonomy should be defined as capacity or behaviour), the majority of authors agree that "the practice of learner autonomy requires insight, a positive attitude, a capacity for reflection, and a readiness to be proactive in self-management and in interaction with others." (n.p.) When talking about learner autonomy, we should take into consideration the interaction between various dimensions of language learning (cognitive, metacognitive, affective and social) that affect the complex process of language learning while the learner is seen from a holistic point of view and is responsible for their learning process (Little, 2007).

The definition of learner autonomy that has gained consensus among researchers is that it "best refers to the capacity to control or take charge of one's learning" and not only to studying without the presence of a teacher (Benson, 2013:14). Benson (2013) claims that learner autonomy can be seen through the approach to knowledge and learning and is therefore divided into a technical, a psychological and a political version. While the technical version encompasses technical skills (such as learning strategies) that the learner needs to use to be in charge of their learning and that can be taught, the psychological version refers to the learner's capacity and cognitive abilities that influence learning. The political version is related to the learning content. At the same time, Benson argues that the definition of autonomy calls for acknowledging three interdependent dimensions of control: learning management, cognitive processes and learning content. These dimensions of control affect the level of autonomy a learner will achieve and they refer to several interdependent processes: to the learner's behaviour during the whole process of learning a language, from planning to evaluation; to directing attention, reflection and building metacognitive knowledge on how to learn; and to defining what will be learned and why. If the learner controls these processes, they could be called autonomous. The level of autonomy that a learner achieves presupposes the learner's active involvement and awareness of their own goals and abilities, which is consequently related to their motivation (Dickinson, 1995). This is very similar to Littlewood (1997), who claims that the level of a learner's autonomy or how autonomous a learner will be depends on the levels of their motivation, confidence, knowledge and skills. They are interconnected components of ability and willingness; a learner may have abilities, but lacks willingness to learn (or vice versa), 
which will affect the language learning process. The higher motivation, the more autonomous learning students want to have in the learning process (Liuolienè \& Metiūnienè, 2006).

Oxford (2003), driven by her dissatisfaction regarding the definition of autonomy, uses a more systematic model of learner autonomy which describes four perspectives on autonomy and she suggests taking into consideration all four of them for better understanding of learner autonomy. Each perspective has a different focus: technical, with focus on the physical situation; political, with focus on characteristics of learners; sociocultural, with focus on mediated learning; and political-critical, with focus on ideologies, access, and power structures (pp. 76-80). They differ in the matter of context, agency, motivation, and learning strategies, which means that teachers need to be aware of the learning environment, active involvement of the learner in achieving the desired goal, how motivated this learner is in learning a language, and which steps the learner takes during the process of learning. By having control over all of these matters, the learner can be regarded as an autonomous learner.

This is in line with Pennycook (1997), who challenged the position and the development of autonomy as a mainstream concept in language learning. Autonomy cannot just be given to students by their teachers and language cannot be isolated from the contexts in which it is used (p. 47). By expressing his doubts about the universal approach to practicing learner autonomy, he refers to autonomy as a concept that is differently understood in different educational environments. In order to support learner autonomy at a universal level, the social, cultural and political contexts of education need to be studied in detail and taken into consideration. Therefore, not every learner is the same, not every learning situation is the same, and not every learning environment is the same when supporting and developing learner autonomy.

Dickinson (1994) states that for him autonomy is not merely a procedure or a method, but a goal of education that implies autonomy training involving both teachers and learners. This kind of perspective makes autonomy a complex concept which implies cooperation between the learner and the teacher. The teacher's goal in this cooperation is to help the learner in this process since it is not very likely that a learner can become autonomous simply by being placed in a learning situation. Dickinson (1995:167) goes one step further and emphasises the importance of looking at 
autonomy as "an attitude towards learning in which the learner is prepared to take, or does take, responsibility for his own learning." Therefore, the learner is responsible for the process of learning and how they will use this knowledge by having control over it, which will consequently make them more successful. What matters is not only what abilities autonomous learners have, but how they are able to use them (Benson, 2013).

An autonomous learner has the freedom in choosing the content, which closely relates to the description of learner autonomy given by van Lier (1996:12). He claims that choice and responsibility are features central to autonomy. This is partly confirmed by Little (2007:2), who simplifies the understanding of learner autonomy by noting that learner autonomy is often considered to be a matter of choice - the learner can choose from several alternatives provided by the teacher. The choices that an autonomous learner will make closely depend on the learner's age, previous knowledge, needs, etc., and consequently autonomy is not necessarily permanent (Little, 1991). When considering formal education, the learner's choice is quite limited - there are constraints such as education policies or chosen textbooks that prevent learners from having a free choice regarding their learning content or learning methodology. Teachers can help by using their knowledge and expertise in methodology and didactics by adapting their teaching to individual learners. Littlewood (1997) recognizes three kinds of learner autonomy that teachers should help their learners develop: learners should be able to use the language independently for communication purposes; they should be able to take responsibility for their own learning by applying appropriate strategies; and they should be able to become autonomous as individuals.

In the context of the foreign language classroom, the characteristics of learner autonomy have best been described at the Bergen Nordic Workshop in 1989. In the report published as the written product of the Bergen Nordic Workshop (Trebbi, 1990), the group of researchers involved stated that learner autonomy was "characterized by a readiness to take charge of one's own learning in the service of one's own needs and purposes. This entails a capacity and willingness to act independently and in cooperation with others, as a social, responsible person." (Dam, Eriksson, Little, \& Trebbi, 1990:102). They continued by describing an autonomous learner as an individual who actively participates in classroom learning, actively interprets new information building 
around previous knowledge, has to become increasingly aware of the aims and processes of learning and can critically reflect on them and use learned knowledge in any other learning situation regardless of the stage in their life. This implies that learner is placed at the centre of the process but is at the same time aided by teacher. The group emphasized the need for both the teacher and student to be aware of the first step in operationalizing learner autonomy by practicing freedom in choosing the learning content.

To sum up, even though learner autonomy implies that autonomous learners have the ability and responsibility to be in charge of their learning, the importance of teachers in the process should not be diminished. Learner autonomy, on the one hand, entails a certain level of learner independence and, on the other hand, interdependence and collaboration of learners and teachers because teachers are still needed to help students in the process of becoming autonomous (Benson, 2013; Benson \& Voller, 2013; Little, 1991; Nunan, 1991). However, an autonomous learner is aware that in order to be a successful learner, one needs to take responsibility for one's own learning and not look at it as the teacher's task. Teachers can apply various methods and use different approaches that help learners be actively involved in developing learner autonomy. This suggests that the roles learners and teachers have in the learning process are complementary in learner autonomy development. In addition, responsibility is also placed on the management of the institution (Lonergan, 1994). However, there are learners who are not ready to be autonomous or do not have the capacity. Teachers should be able to recognize that and be skilful enough to adapt to the given situation.

One context where autonomy as the capacity to be in charge of one's learning and its active implementation can be studied is in self-access centres where learners can choose the learning content based on the materials that had been collected and prepared for them. During this learning process, the learning is self-centred and the teacher's role is more of an advisor or counsellor, a guide for the student (Gremmo \& Riley, 1995). The role that self-access centres have in language learning has been well described by Sheerin (1997) - it is to promote learning which would enable learners to learn how to learn and thus become independent. According to Morrison (2008), selfaccess centres serve as places where the focus is placed on increasing knowledge and proficiency by developing learning strategies that would be efficiently achieved outside the regular classroom. 
Self-access has been present in the form of encouraging learners of any age to discover new knowledge by themselves (Lonergan, 1994). However, self-access is only successful if they are not alone in this process: they are accompanied by teachers, who have the crucial role in the learning process, and managers, whose role is to support the functioning of self-access centres due to their value on pedagogic level and to encourage development on administrative level (Gardner, 2011). The crucial role of the teacher relates to planning the course, to choosing teaching and learning materials, and to being a bond between the learners' needs and management's plans. Learners might not be aware of the pedagogical values of a self-access centre and they need a higher sense of self-awareness and self-discipline than when working in a regular classroom. It means they should be aware of their learning objectives, abilities and strategies to be able to get the maximum from their learning and become autonomous. The same level of awareness is needed in tertiary education environments, where it is expected of students to independently broaden their knowledge based on the content and materials presented by teachers who are at students' disposal during the learning process. Therefore, self-access centres can be perceived as environments which provide students with necessary materials they can choose from to learn and can thus be compared with online environments - environments which students can use as the source of learning materials that are in accordance with students' own preferences and interests, with teachers at their disposal.

As Littlejohn (1997) emphasizes, it is not enough to deliver teaching to learners, but to make them active agents in the process by using their output (that is, the content they produced), which can then be used as a teaching resource. Learners who practice self-directed learning are those who determine the objectives, progress and evaluation of learning by themselves, which consequently leads to autonomy as a product of such learning (Benson, 2013:10). Even though being an autonomous learner among other things implies certain level of individualization, this does not mean being isolated; language learning requires social interaction. The process of language learning presents a continuous process in which a learner strives toward increasing their own language learning awareness and learning how to be able to recognize and use resources needed to achieve the desired level of skills. 
With the development of technology, globalization and the growing significance of learning languages, learner autonomy has gained importance and has been recognized as a concept which enables learners to be in charge of the learning process. The teacher is not in the centre any more, but is there as a facilitator, somebody who guides the learner through the process of language learning and towards the 'empowerment' through the new digital environments (Lamy \& Hampel, 2007). In these new environments, learners can communicate with their peers outside the classroom. Therefore, a beneficial component is learner networking, which would connect learners of different languages with the purpose of learning each other's language.

As mentioned earlier in the chapter, learner autonomy implies independent learning. This has been shown by giving the example of learning centres where learners have the opportunity to use available resources while learning a language and to communicate with their advisors in case of the need for support by using technology (Makin, 1994).

Learning in a blended environment could present an opportunity similar to self-access centres in which learners have teacher-created resources in one place (for example Moodle) and at their disposal during their learning process. In addition, they can use other resources more independently (for example by glossary or a wiki) and, if needed, communicate with others, asking for the teacher's or even their colleagues' support (for example using forum). The only issue that might arise is how much students are ready to use these opportunities.

Self-access does not immediately translate into autonomous learning. In order to develop autonomous learning, a certain level of interdependence of learners and teachers is required; students should have the option of relying on teachers in case of any problems that might appear. Independence and interdependence are both features of learner autonomy since the learner, while developing personal autonomy, develops social and political autonomy (Benson, 2013). With the recent rapid technological development, we have become witnesses of the need for developing and fostering learner autonomy for the sake of our learners. The new technologies and available online tools require a certain level of autonomy, and in order to use all the affordances of these tools, learners have to develop autonomy to a certain extent. Unfortunately, this can sometimes be too challenging a task due to various reasons: learners not being prepared for using the affordances of 
technology, or learners working on CALL or CMC projects that are not a part of regular assessment procedures, which learners then see as an add-on activity (Schwienhorst, 2009).

This influence of technological progress has also transformed the lonely activity of learning at a distance into a social activity. This has been well described by Moore (1994:1), who describes autonomy in the context of distance learning as "the potential of distant learners to participate in the determination of their learning objectives, the implementation of their programs of study, and the evaluation of their learning." He claims that distant learning (Open Universities in particular) has enabled interaction between teachers and learners (as group members or individuals) and individual learners and virtual groups. As mentioned earlier in the chapter, this is a challenge and sometimes even impossible due to the formal restrictions of the curriculum or educational policies.

Learner autonomy is a concept which is not absolute, but can be expressed in degrees (Nunan, 1997:195) from awareness, which presupposes pedagogical goal and content, to transcendence, when learners take acquired knowledge and skills outside the classroom and become teachers and researchers. The use of technology can have an impact on the reached degree of autonomy, that is the level of technology skills might help learners move from to the stage of creation, where they as members of a group create content based on existing materials (for example in the context of a wiki). Where does this leave learner autonomy in the context of blended learning? Even though autonomy, technology and self-access are seen as intertwined concepts, Schmenk (2005) warns that even though autonomy is often technologized, or there is the idea that using technology immediately leads to learner autonomy, it cannot be just triggered the moment a person starts using a CALL program. It is a process which is closely related to the learner's attitude and motivation towards learning. An autonomous learner will use the availability of an autonomous classroom and blend their own individual traits with prepared activities with the purpose of using the knowledge they already have to develop new knowledge. This study understands learner autonomy as a concept which can help students to apply existing knowledge and the skills that they have acquired to work on their own, without the teacher's presence. The teacher's task is to be at their disposal in case they need assistance and to monitor their performance and activity. Based on the information that a teacher can gather about students' activities, some conclusions regarding learner 
autonomy can be made - this can be qualitative or quantitative data on how often or to what extent students work on their own successfully, allowing the teacher to assess the level of their autonomy (Murase, 2015:38). This approach of collecting and analysing data about the students' autonomy has been used in the study described in the dissertation.

Before ending this section and moving on to the next chapter which will describe the study, it would be useful to briefly explain how the concepts of ESP, blended learning, vocabulary development and learner autonomy are connected. The following paragraphs will describe the connection between them, with the purpose of relating them more directly to the study.

CALL and CMC are related to learner autonomy and vocabulary acquisition as the concepts that might be affected by them. Therefore, how do CALL and CMC or using technology in general relate to learner autonomy and vocabulary acquisition? A Croatian example of how to use teachers' and learners' skills to enrich the learning environment is the award-winning project Engwiki that has already been mentioned. The project was started with the purpose of improving students' learning process and increasing their learning outcomes as well as their motivation, with the focus on skills development and vocabulary acquisition. The lead author was also the teacher. The authors found that the use of wikis in ESP and in English as a second language (ESL) courses can have positive impacts on the learning environment and on students' vocabulary acquisition.

According to Beatty (2010:11-12), autonomy is fostered by CALL in different ways: it enables students to work on their own, when it suits them, and they potentially become more aware of their learning. However, we cannot be sure to what extent that is realizable, due to the fact that many "CALL software programs simply follow a lock-step scope and sequence". However, there are also aspects of CALL applications that allow for more learner input and control. Most for example to encourage revisiting with the focus on reviewing those language forms that need more practice and thus fostering learner autonomy. The research has shown that CALL in general can have a positive impact on learner autonomy (Farivar \& Rahimi, 2015; Mutlu \& Eröz-Tuğa 2013). Some other positive views include White (2003) who claims that learner autonomy is a crucial notion regarding computer-mediated learning: using $\mathrm{CMC}$ in most of the cases implies working without the direct teacher's presence; Fisher, Evans \& Esch (2007) have shown that CMC is an excellent way of 
promoting learner autonomy; Chapelle (2001) also refers to the efficacy of CMC applications in giving learners more control and autonomy over their own learning; Wach (2012) has shown in that if learners are willing to use $\mathrm{CMC}$ for the purposes of language learning, CMC has great potentials in language learning. The research that will be presented in Chapter 5 of this dissertation will try to give evidence on how CMC can be used to promote and develop learner autonomy based on activities that require learners' active participation in creation of learning materials with special emphasis place on vocabulary.

Now that all the concepts important for this dissertation (blended learning, vocabulary development and learner autonomy) have been explained in more detail, the following portion will discuss them in the context of ESP, which has shown to be a fruitful research area in the previous sections. In addition, if ESP is understood as an educational context, it becomes a context which could offer tertiary institutions some feedback about how their students would benefit from learning ESP by using technology (see Arnó Macià, 2012; Bloch, 2013; Bourne Moore, 2005; Dashtestani \& Stojković, 2015). Blended learning, as an example of learning by using technology, is an excellent approach to ESP due to the already discussed features such as availability or flexibility. It has been studied mostly in the area of business (Czellér, Hajdú, \& Wiwczaroski, 2015). That is one of the reasons why this study will try to give a better insight into the area of technical topics through technical vocabulary supported by blended learning; the positive effect of blended learning on vocational vocabulary has already been presented in research (Lesiak-Bielawska, 2012; Tosun, 2015).

Moreover, there has been evidence that the ESP context supports learner autonomy (Banditvilai, 2016; Chirimbu, \& Tafazoli, 2014; Dziuban, Moskal and Hartman, 2005; Fučkan Držić, Seljan, Mihaljević Djigunović, Lasić-Lazić \& Stančić, 2011; Lungu, 2013). Extending learner autonomy in ESP to more students is more than welcome (Ajideh, 2009; Belcher, 2013; Gardner, 2007; Xu, 2012) due to the increasing need for life-long learning. By being aware of the potentials that technologies offer and using them for a specific purpose such as language learning in a specific context, learners are able to choose specific online content that contributes to their language 
improvement. This means that they are ready to use a particular type of technology in accordance with a particular language learning purpose (Trinder, 2017).

Based on what has been said in this chapter and the literature that has been presented in the sections, the study that will be described in the next chapter tries to tackle the role that blended learning has in tertiary education institutions in the context of learning English for specific purposes. Special emphasis is placed on vocabulary acquisition and fostering learner autonomy in a blended learning environment, compared to traditional ways of learning a language. The research presented in this chapter has shown that even though blended learning is present at higher education institutions, it still needs to be addressed in research to give evidence of its benefits for vocabulary acquisition as an important part of language learning. CMC tools are at the disposal of students and teachers, and if used to their full potential can be of great use. Their potential as well as their impact on language learning and learner autonomy in a blended learning environment has been noticed and that has led to the study that will be described in the next chapter. The chapter will consist of two sections that will explain motivation for the study and consequently its aims and hypotheses. 


\section{THE STUDY}

\subsection{Motivation for the Study and its Context}

In Croatia, using open source learning management systems (such as Moodle) has become a regular part of teaching in many subjects at tertiary institutions. In these contexts, e-learning is mostly used as an additional tool for learning, taking account of the fact that students growing up in a digital world are inclined towards using technologies and tools that have great potential in educational settings. This can be seen in the growing number of students who prefer a blended learning environment and would like their teachers to use more technology (Brooks \& Pomerantz, 2017). When it comes to teaching foreign languages in Croatia, according to Mikulan, Legac, \& Oreški (2017), teachers still do not use the available technology and tools to their full potential, but their use has increased when compared to some past research (Mikulan, Legac, \& Siročić, 2011). It is important that teachers realize that by introducing technologies into English language teaching, students can be supported in their learning without always having to be physically present at the lessons, which should enable them to display a greater degree of control over particular aspects of their learning (Benson, Grabe, \& Stoller, 2001). This is particularly important for part-time students at tertiary institutions who very often need to be excellent time managers in order to fulfil their obligations at university, at work, and at home. This may mean skipping lessons and missing important information during lectures because sometimes, due to the number of courses that students have to take, some classes are timetabled earlier in the day. In the case of language acquisition, students' physical presence could affect the development of skills needed to speak a language.

The motivation for this study has been purely professional: being an English language teacher at a tertiary institution in Croatia made me aware of a very small difference between part-time and fulltime students regarding their obligations related to their studies. Even though they are called 'parttime students' they have to pass the same number of courses as full-time students and they are very often in employment, which makes their situation even more challenging.

The study was conducted at University North, which at the time the research was conducted was called Polytechnic of Varaždin. It offered six different programmes at undergraduate level: 
Multimedia, Design and Application; Technical and Economic Logistics; Mechanical Engineering; Electrical Engineering; Civil Engineering; and Nursing. Only Nursing students did not have obligatory English lessons and were not included in the study. Foreign Language I - English and Foreign Language II - English is the name of the course all the other students attended. It is taught as a two-semester course which consists of linguistic and extra-linguistic content related to general and specific purposes corresponding to an engineering profession. The course follows the existing syllabus. During both semesters students attend 30 lectures and 30 practice lessons. The teaching pattern is two 45-minute lessons of lecture one week and two 45-minute lessons of practice the week after, each week respectively. At the end of the second semester this amounts to 60 lessons of English language. This is not enough to progress to a higher level ${ }^{8}$, but students are exposed to English language in a formal and controlled environment. During practice lessons students are usually divided into two groups (full-time students and part-time students) and the lectures are held for all of them together. The teaching material (texts, videos, tasks, etc.) are compiled based on the syllabus for English Language course at University North and adapted to be used in printed form, or on the Internet, alongside activities designed by the teachers.

At University North, the amount of time that part-time students are required to spend at the university is $50 \%$, while the requirement for full-time students is $70 \%$. In most of the cases, attending even $50 \%$ is quite challenging for the part-time students who work since their study load is the same as of full-time students. Another reason for that is that the majority of them have a job in the STEM area, which often implies working in a factory and therefore working shifts. The consequence is that throughout the academic year, the students are often absent from English language classes and therefore have to rely more on independent studies and their ability to autonomously grasp the content taught during the lessons.

The University had already been using an LMS (Moodle) and teachers of the professional-focused courses could upload their lesson materials and make them available to students alongside other activities that Moodle offers. The same was done for the English language course whose syllabus contains not only general topics (grammar, culture), but also technical topics related to their

\footnotetext{
${ }^{8}$ https://www.englishprofile.org/images/pdf/GuideToCEFR.pdf
} 
specific profession, which means that vocabulary is an important part of the language for them. As a teacher whose principal concern is to do everything possible to provide a good, efficient and pleasant learning environment for students so they could acquire or improve their foreign language skills and pass the exam, I realized that there were certain issues which seemed to relate to the mode of study (part-time vs full-time students). This sparked my interest and motivated me to observe the differences between the two modes more closely to get more insight into some of the issues. For example, part-time students mostly rely on materials published on Moodle and very often cannot be present at face-to-face lessons. The fact that they are not present in class to the same extent as their other colleagues might place them in a slightly unfavourable position and therefore have an influence on the language they are able to produce at the end of the course. This might affect getting sufficient input needed to develop vocabulary or improve the language level and pass the exam at the end of the course. In addition, some of the part-time students mostly work on their language on their own, and without the teacher's feedback might not be sure whether their language is improving or not. Since professional vocabulary is of great importance both for their jobs and their final exam, they need to be certain that they can acquire the same amount of vocabulary as their full-time colleagues. However, this can be very challenging since working on one's own requires a certain level of autonomy which is a rather individual characteristic. Not all students are autonomous enough to be able to fulfil the obligations they have as students of the course. In addition, working according to their own schedules/preferred times of day requires a computer in order to have access to the teaching and learning materials used by the teacher at faceto-face lessons. It cannot be expected that all of the students will have sufficient technological literacy skills to work in a blended learning environment. Consequently, this might challenge the teacher to adapt his or her teaching to individual needs of students in order to facilitate language development. The question that arises on this particular matter is the extent to which this facilitation should be done. To what extent is it reasonable?

Upon reviewing relevant literature, I found that blended learning at tertiary institutions had been researched in combination with vocabulary acquisition and learner autonomy, but there was a gap with regard to the effect of a blended learning model in comparison with the traditional approach 
on the specific purposes vocabulary acquisition through the through the prism of SLA and theories of input and interaction.

The study was conducted at University North (former Polytechnic of Varaždin) with the population available - full-time and part-time first-year students enrolled in five different programmes who were attending English Language course in the second semester. These were Multimedia, Design and Application; Technical and Economic Logistics; Mechanical Engineering; Electrical Engineering; and Civil Engineering. These students were used as participants since the author of this dissertation was their teacher, that is they represented a convenience sample. Throughout the first semester, the students were encouraged to use Moodle, the institution's learning management system, to get access to teaching materials. The course consisted of linguistic and extra-linguistic content related to general and specific purposes and a profession, and it followed the existing syllabus. For the purposes of the study, the students were divided into two groups $-\mathrm{a}$ 'face-to-face learning' group and a 'blended learning' group. The participants were of approximately the same age, similar educational background (mostly technical schools), and similar exposure to English within formal and informal environments. Therefore, they were a representative population for investigating the professional vocabulary development of students in this kind of tertiary education in two different learning environments (face-to-face and blended) and the influence this has on fostering their learner autonomy.

The aim of the study described in the following sections was to provide deeper insight into how blended learning contributes to students developing an awareness of foreign language acquisition, especially regarding learner autonomy, and to successful acquisition of foreign vocabulary compared to traditional classroom learning. This will generally contribute to the knowledge of second language vocabulary acquisition. By knowing that learners differ in terms of rate of second language acquisition, learning processes and outcomes (Ellis, 1994; Cook, 2003; Ortega, 2011), they also differ in terms of their learning goals and behaviour and their level of technological literacy. Thus, the results will also contribute to teaching practice and aid part-time students. 


\subsection{Aims and Hypotheses}

The importance of learning foreign languages at tertiary education institutions in Croatia has been growing in recent years. Increased mobility within Europe and beyond requires competence in general English as well as knowledge of English for specific purposes. With the introduction of modern technologies into classrooms, learning does not have to be done solely face-to-face. Since blended learning of languages at tertiary institutions is still an under-researched area, this study will investigate whether using online elements in an ESP course can foster students' vocabulary development to the same extent as face-to-face learning can. In addition, the aim of the research has also been to investigate the role that blended learning has in learner autonomy development. In order to achieve these aims, the following three hypotheses have been formulated:

1. Blended learning of ESP vocabulary has the same effect on vocabulary acquisition as face-toface learning.

2. Blended learning raises students' awareness of the possibility of more autonomous and independent English language acquisition in relation to the traditional classroom learning.

3. The effect of blended learning on the acquisition of ESP vocabulary and the level of students' self-assessed competence is related to the students' skill of using a blended approach to learning, that is their technological skills and the use the technology for learning purposes.

Thus, based on two different approaches to learning and teaching (face-to-face and blended), the study will focus on how new linguistic information can be used as input (based on the teaching materials published on Moodle) that through the process of using technology is used in a new linguistic situation (creating wikis and glossaries). It will give an insight on input-intake-output processes that are realized during English language activities used in the study, considering the notion that the conversion of input into intake is central to an understanding of SLA. To be more specific, by investigating this process in a blended learning environment and comparing it to the face-to-face environment, the role of technologies becomes more prominent and the usual interaction between learner and teacher becomes interaction between learner and learner and learner and computer with the teacher taking on a monitoring role. The study is also exploring if using modern technologies could be of significant help to students during the process of vocabulary 
development. It will provide information on how technology can be used within a blended environment by looking at learners' self-assessment of their technology skills and their technological skills used in vocabulary development. As such, it will generally contribute to the role that technology has in second language vocabulary acquisition. By using a mixed methods approach, the study will examine tertiary students' vocabulary development as well as the development of their learner autonomy. It is expected that the study will show that blended learning has a positive impact on both. The findings will inform Croatian tertiary education and give further insights into the process of blended language learning more widely. The results will also contribute to teaching practice and aid students in their second language learning. 


\section{METHODOLOGY}

The first part of this section will discuss the main points of interest for this study before giving an overview of the methodological approach to the study. It will continue with the description of participants and their distribution to explain how the two groups (blended learning (BL) group and face-to-face (FtF) group) were formed. Then it will describe how the BL group worked during the semester, what assignments they had and how the results of these tasks were recorded for the possibility of their analysis. Activities, tools and instruments used in this research will be described based on dependent and independent variables and the reasons for their choice will be given. Finally, all of this will be summarized.

\subsection{Points of Interest for the Study}

This study intended to investigate three main points of interest: to find out whether there was a difference between the participants placed in the FtF group and the ones placed in the BL group with regard to their vocabulary learning; whether there was a change of perception of more autonomous learning between the first and the second point of measurement, in the BL group, by examining their ESP self-assessment results and through specific questions of the questionnaire; and whether the students' language competence as assessed by themselves on the ELP and their vocabulary acquisition is related to the blended approach to learning. It was assumed that, the students could acquire vocabulary in a blended learning environment to the same extent as in a traditional face-to-face environment. In addition, it was assumed that students learning in a blended learning environment become aware of the possibility of autonomous learning unlike in a traditional classroom learning. Here we can discuss the question of learner autonomy only on a descriptive, informative level since we do not have it in the first measurement. Also, we assumed that the effect of blended learning on professional vocabulary development is related to the skills of using blended learning approach. This was investigated by looking at both professional and general vocabulary. In this case, general vocabulary was used as a control measure and these two measures were looked as one. 


\subsection{Overview of the Methodological Approach}

The research methodology used for the study was based on a mixed methods approach - both qualitative and quantitative data was collected to enable a deeper insight into the effect blended learning has on English vocabulary acquisition at tertiary level. The study used convenience sampling, the students of University North. Qualitative data was going to give an insight into the students' perception of and their experience with modern technologies used in learning the English language. Quantitative data was used to show the students' progress regarding vocabulary acquisition in a blended environment compared to traditional face-to face learning. It was decided to analyse the data using the statistical computing language $\mathrm{R}$ (R Core Team, 2017 ${ }^{\circ}$ ) and applying the corresponding metrics.

\subsection{Participants}

As has been described before, the study was conducted at University North, Croatia, in the second (summer) semester of 2014/2015. Ethics Committee gave consent to the research proposal at the ethical session on 17 June 2014. Due to the fact that all the participants were of full age at the time of research, their written consent to participate in the research was not required. Participation was voluntary. Even though the students had to earn their right to take the exam, a minimum amount of activity was needed - participation in the study did not necessarily mean passing the course, and vice versa, lower participation did not immediately lead to failing the course.

The information on the participants of the study was gathered by the means of a questionnaire developed by the teacher. The questionnaire was anonymous, but a coding system in form of a combination of letters and numbers was used and will be described later in the text. At the beginning of the semester, the students were given the questionnaire which consisted of five sections. The information gathered was used for collecting demographic data, students' general perceptions of their use of technology in general and CMC tools in particular for private and academic purposes, data about the technology skills of the students, their attitude towards using technology for language learning and using the Moodle platform, and general attitude towards elearning. The data obtained had the purpose of providing a broader picture and gaining an insight

\footnotetext{
${ }^{9}$ R Core Team (2017) R: A Language and Environment for Statistical Computing https://www.R-project.org/
} 
into the attitudes and perceptions that tertiary students have regarding the use of technology for private and academic purposes. Their attitudes towards technology use and their perceptions of using technology in various learning environments (face-to-face, blended and completely online) were studied to investigate their readiness and willingness to use technology for the purposes of learning English at their higher-education institution. At the same time, it gave an insight into the perception of the interaction between students and teacher and the development of learner autonomy. The results obtained by analysing the answers of each of the questionnaire sections will be described in detail in the context of the hypotheses.

However, before getting deeper into the description of testing the hypotheses, it has to be specified that the questionnaire was piloted early in 2014 (January) at one of the English lessons. The sample consisted of students of the Media University in Koprivnica (which later became part of University North), who were attending General English course in their first year and had profiles similar to those of the participants in the study (regarding age and English language background). The aim of the pilot questionnaire was to test and finalize the instrument to be used in the main study and to detect potential misunderstandings and problems or flaws in the design and implementation. It was filled in by 37 respondents. Upon analysing the questionnaire results and taking account of the students' comments, it was concluded that the questionnaire could be used for the main study with minor corrections to the design. Thus some of the questions were placed in tables to form reasonable units; instead of asking students to express their opinion using a blank line for writing down the answer using the numbers 1 to 5, a 5-point Likert scale was used; two open questions that referred to the tools the students used were changed to multiple choice questions. The results of the pilot questionnaire will not be discussed in this dissertation because there was no comparison involved and the obtained data on using technology were very similar to the data collected and analysed in this study.

As previously mentioned, the section of the questionnaire which contained demographic questions was the fifth section, but it will be discussed in the paragraphs to follow to describe the participants and their characteristic. It gave an insight into the students' study programme, the study mode (fulltime or part-time), the number of years learning English language, their gender and their age. 
A total of 179 first-year students (98 full-time and 81 part-time) who were enrolled in five different programmes at undergraduate level (Multimedia, Design and Application; Technical and Economic Logistics; Mechanical Engineering; Electrical Engineering; Civil Engineering) participated in the research and represented the population of undergraduate students learning English in the context of the specific purposes for this study. Their distribution according to their programme of study is presented in Figure 1, which shows that the numbers of students studying a particular programme are quite similar. Multimedia, Design and Application is the only programme with a slightly higher number of students, which is closely related to the enrolment policy of the University. However, the differences or similarities between students and their results with regard to the programmes were not studied as the numbers of students in each programme were not sufficient to draw any conclusions based on the obtained results.

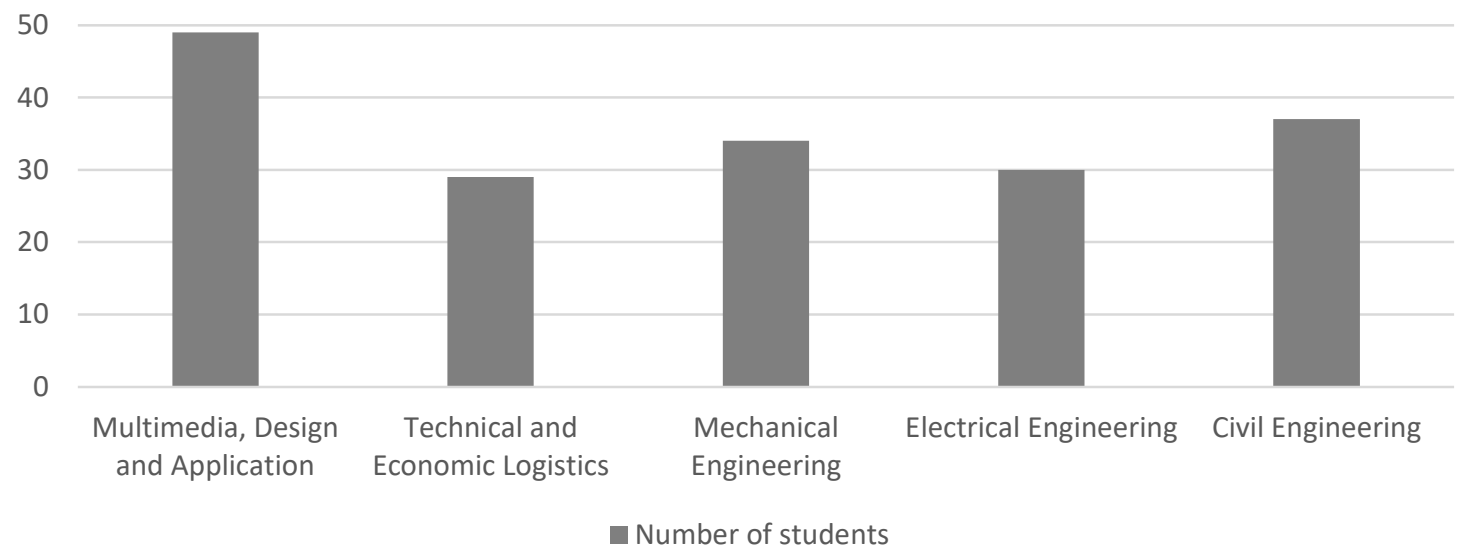

Figure 1. The number of students attending the English language course based on their programme of study

Most of these 179 participants were male (123), which is not surprising given the fact that this is a higher-education institution with programmes in the predominantly male STEM area (Blackburn, 2017; Wang \& Degol, 2017). The participants' median age was 20, with the youngest participant being 18 and the oldest 39 . Since there were pre- and post-study values for demographic variables, these pairs of variables were combined into one variable. In the case of different age reported in 
pre- and post-testing, the higher value was taken as the final one due to the possibility of it being related to the time flow of three months ${ }^{10}$.

Their median time of learning English in their first year of study was 9 years, which is in accordance with the situation in Croatia and tertiary education in general, with students learning English in elementary school mostly for 5 years and in high school for 3-4 years. Since most of the students taking the course (but not all) continue their English language learning that they started in elementary and/or high schools, their English language proficiency level is often mixed and the groups are thus heterogeneous. Nevertheless, it is expected of learners at university to be at intermediate or advanced level (Dudley-Evans \& St. John, 1998), which means that they should be in a position to follow the content of the ESP course.

In order to approximately determine and confirm the students' level of English language knowledge, they were given an online test ${ }^{11}$ that contained grammar and vocabulary questions (see Appendix A). It is a simply organized test with 15 multiple choice questions. Even though choosing this placement test has its weaknesses (for example, it does not take into account all four skills (speaking, reading, writing, listening) and therefore cannot give precise information on the student's level (it only gives a proximate result, and there is a possibility that students guess the answer to the questions since it is a multiple choice test), it was chosen for its shortness, immediate availability of its results and being free of charge. In addition, questions get easier or harder depending on how well the student answers them. The test needed to be completed in less than ten minutes, from the comfort of the students' homes, whenever they felt ready. It was used for the teacher's information only so students could be placed into the two groups.

The results obtained in the test were print-screened by students of each study programme and sent by e-mail to the teacher (see Appendix B). The result stated the level in accordance with the Common European Framework of Reference for Languages ${ }^{12}$ (CEF or CEFR) which students could

\footnotetext{
${ }^{10}$ There is a possibility that a student celebrated their birthday in those three months so the age stated in the pre-test could be 19 and in the post-test 20. Therefore, the higher value (20) was taken.

${ }^{11} \mathrm{https} / / / \mathrm{www}$. stuff.co.uk/testyourlevelofEnglish.htm

12 https://www.examenglish.com/CEFR/cefr.php
} 
refer to. In that way, students were informed not only of their level, but could also check what is expected of them to know or what their skills are at a certain level.

Their summarized tested levels are shown in Figure 2. The values confirm that the level of the students' English language knowledge prevailing is intermediate/advanced, which is in accordance with the expected level.

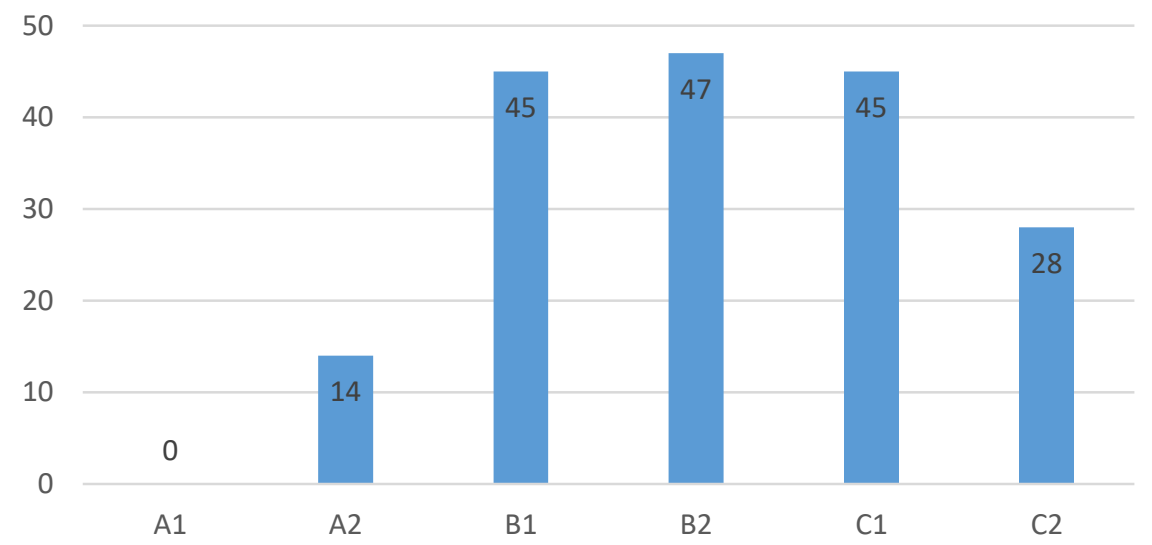

Figure 2. The students' English language levels (CEFR)

After the initial placement performed by the teacher (equal numbers of students in each group according to their English language level) and following the students' preferences, they were placed in two groups, a 'face-to-face learning' group (FtF) and a 'blended learning' group (BL), with 95 (53\%) of them in the FtF group and 84 (47\%) in the BL group. Even though the aim was to have the same number of students in each of the groups to achieve homogeneity, due to this research being voluntary, students were put under no pressure to be placed in a group in which they did not want to be for whatever the reasons. This accounts for the small difference in numbers. Nevertheless, approximately the same number of students being of similar English language level were placed into the groups. The distribution of levels within the groups can be seen in Figure 3. 


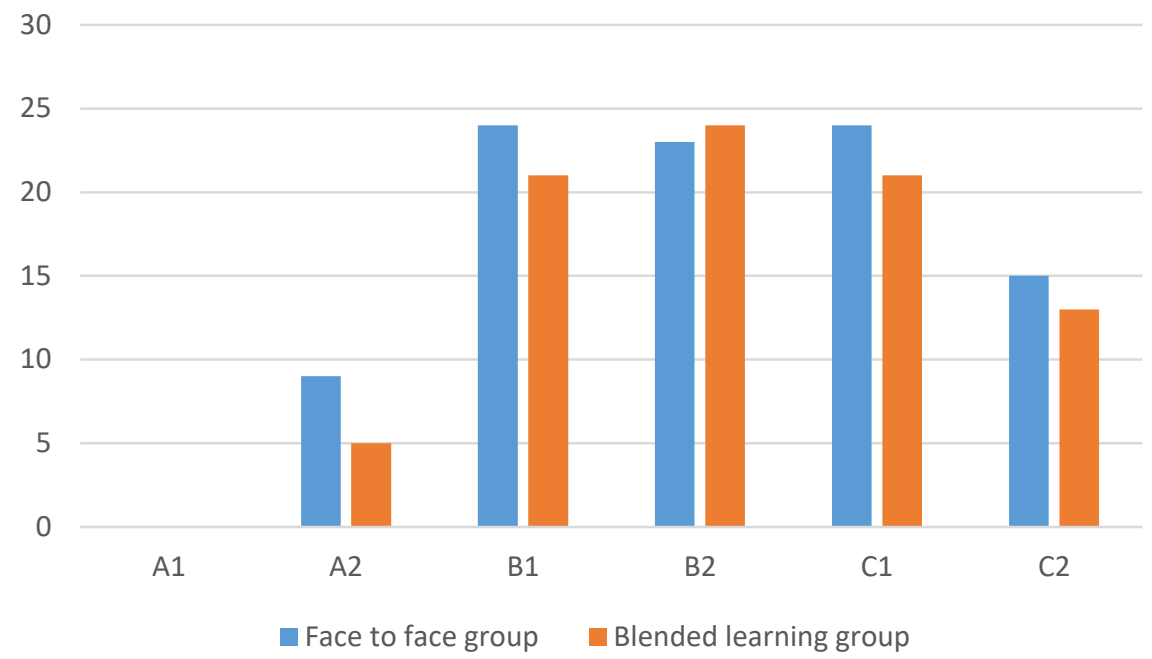

Figure 3. The students' English language levels (CEFR) as distributed in the two groups

At the point of conducting the study, the students attended the course Foreign Language II English. Throughout the first (winter) semester, they were encouraged to use Moodle to get access to teaching materials either for midterm exam preparation or to find out about the content and activities that were presented or carried out in the lessons that they did not attend. This had been the practice in other courses, too. All the materials used in the lessons (presentations used during the lectures, handouts used in practice lessons) were uploaded immediately after the lesson, together with any other additional materials that the teacher considered would be of use to students to additionally support the lesson content.

During the semester, the students in the FtF group attended the English course in a traditional way, participating in the lectures and the practice lessons. The students in the BL group did not have the obligation of attending the full amount of regular lessons that are required by the University to fulfil the minimum requirements in order to pass the course (this was approved by the management). Instead, they were provided with assignments on the Moodle platform, which covered the same content as the face-to-face lessons together with additional interactive activities available on Moodle (wiki, glossary) and could be considered an experimental group. Since 
blended learning is the combination of two types of learning, blended learning in this study is interpreted as a 20:80 ratio, in favour of the online components - that is, the students had to be physically present at $20 \%$ of the lessons while the remaining $80 \%$ of the work was done online. This means they had to be present at three lessons throughout the semester - they attended the first (introductory) lesson and the last lesson, which was suggested by the teacher since these are the most important for fulfilling the requirements of the obligatory course (regarding the necessary information on the course and receiving the signature as a piece of evidence that the minimum requirements have been fulfilled), and they were told to choose their third lesson themselves. If there were any questions, the teacher was available online via e-mail and Skype and the students could communicate between themselves via a forum on Moodle. This kind of communication was suggested by the teacher as a useful form of communicating during the obligatory activities. The students would meet during other lessons in the classes associated with their programme, so faceto-face communication between them was not excluded, but was not considered to be of importance for this study and also would have been extremely difficult to track.

\subsection{Blended and Face-to-Face Learning and its Influence on Vocabulary Acquisition and Learner Autonomy}

In order to test the hypotheses, independent and dependent variables were set: blended learning and face-to-face learning of professional vocabulary as independent variables, and vocabulary acquisition and fostering learner autonomy as dependent variables. The aim of this study was to compare the learners' performance in terms of a range of activities in a blended learning environment with learners' performance in a face-to-ace context to shed some light on how professional vocabulary can be acquired and learner autonomy fostered.

In order to investigate whether blended learning of ESP vocabulary has the same effect on vocabulary acquisition as face-to-face learning or a different effect, vocabulary that was to be learned in the context of the lessons or online was tested. For that purpose, the students' vocabulary frequency level was tested using the Vocabulary Levels Test (Nation, 2001) at the beginning and the end of semester in print form (see Appendix C). It was administered to both groups. This kind of test enables measuring learners' vocabulary size and allows the researcher to chart the growth 
of learners' vocabularies (Nation \& Beglar, 2007). The test consists of 40 multiple-choice questions (with the options of ' $\mathrm{T}$ ' if a sentence is true; ' $\mathrm{N}$ ' if a sentence is not true; ' $\mathrm{X}$ ' if the sentence is not understood). Students get a point for each correct answer. The test measures the receptive knowledge of the most frequent 1000 word families which contain the greatest proportion of spoken and written English vocabulary, and it was chosen as evidence whether even those students who had never learned English in a formal environment would be able to understand English at a minimum level. It is intended to test the knowledge of words required for the skill of reading. Many students of the University do not use English outside the classroom frequently since the majority of them work in factories or in positions that do not require productive knowledge of English. Nevertheless, they should be able to understand the words that can be found at the highest frequency level. The test is available online ${ }^{13}$ with the option of immediate feedback. However, in order to ensure its completion, it was administered at the first, introductory lesson. It was used as a measure supporting the results of the vocabulary test described in the following paragraph.

In addition to the Vocabulary Levels Test, at the introductory lesson, the students were given a test which covers the obligatory programme of the English Language course and represents the main part of the regular final semester exam (see Appendices D1-D5). The test was designed specifically for the purposes of the research, with specific linguistic topics related to a particular profession (vocabulary) and using different types of activities (gap filling, true/false statements and translation). Its main goal was to test professional vocabulary through several activity types.

The first task was a gap-filling activity. There were 5 sentences and each had a word missing. All sentences were taken from the materials used at the lessons and referred to the topics specific for a particular profession/study programme.

The second task consisted of 10 sentences, and the students had to decide whether these were true or false. Six of them were false. These sentences were also extracted from the teaching materials used at the lessons and were testing students' understanding of the statements related to their profession/study programme.

${ }^{13}$ Available at https://www.lextutor.ca/tests/levels/recognition/1k/test_1.html 
The final task was to translate ten key words that appear in the texts related to the profession/study programme, five from English to Croatian, and five from Croatian to English. Students got points for correct answers only (spelling mistakes were not tolerated).

Both of these vocabulary tests were administered twice: first in the introductory lesson and then in the final lesson of the course. They were administered together to both groups - the FtF group and the BL group - to provide evidence whether the students have the basic knowledge of words required for reading that will allow them to access the content rich with words belonging to professional vocabulary due to their high frequency in the lesson materials, that is basic knowledge of professional vocabulary which is required by the course syllabus. A coding system was used to enable a comparison of the results at the beginning and at the end of the semester. The participants had to write the first two letters of their mother's name, their own birthday expressed in a two-digit number according to the day of birth, and the last two letters of the street where they lived (e.g. a student's mother's name is Sanja, the student was born on the 24th of July, and he lives in Zagrebačka street - the code is SA24KA). This data can be used since it is something that does not change during the course of time and was therefore considered to be a reliable code which students were able to use at the beginning and at the end of semester. In addition, forgetting the code is in this way is impossible since it does not even have to be memorized.

The answers of both vocabulary tests were linguistically analysed and the results were compared regarding the type of learning (face-to-face and blended) and added to the final vocabulary score. The scores at the beginning of the semester and at the end of semester were compared. Comparative analysis allowed conclusions to be drawn regarding the hypothesis regarding vocabulary acquisition using a blended and a face-to-face approach.

With the aim to ensure that the students working in a blended learning environment were exposed to professional vocabulary to a sufficient extent, it was made sure they did several activities during the semester that would encourage reading on the topics that were discussed at the lessons in the face-to-face environment. They had to do three different tasks throughout the semester, without any specific time requirements (the sole restriction was to work on the tasks until the end of semester so as to calculate their activity points needed for the final grade). All the tasks required 
both greater independence and group work for the experimental group. The tasks consisted in creating a wiki related to their respective professional topics (multimedia, logistics, mechanical engineering, civil engineering, electrical engineering), a wiki focusing on conditional sentences, and a glossary of professional terms, all of which will be described in details in the following paragraphs.

The first task the BL group had to complete was to collaborate in order to create a wiki related to the topics important for the particular profession. A wiki was chosen as a CMC tool which does not require a high level of technological skills and it can be easily monitored by the teacher. The students were asked to summarize what they had learned by going through the materials posted on Moodle that they had to work on independently (the topic of colours for Multimedia, Design and Application; mechanical properties for Mechanical Engineering; bridges, buildings, roads for Civil Engineering; electricity, circuitry, transformers for Electrical Engineering; retail, transportation, inventory management for Technical and Economic Logistics). They could write their own sentences, explanations and descriptions of the topics and add links to some webpages that covered the topics. They were asked to make sure that they included the most important vocabulary taught at the lessons presented at regular teaching hours for the FtF group and which were uploaded on Moodle by the teacher. In addition to the 'required' vocabulary, they needed to add new sentences/words/phrases to the existing text as well as to correct other student's mistakes, if they noticed them (both content and grammar mistakes). If they were not sure about the mistake, they could check with the teacher. The purpose of the task was to use their linguistic and extra-linguistic knowledge to increase their vocabulary by reading and later writing about the topics related to their profession and to the materials available on Moodle that had been used at the lessons while teaching the FtF group.

The second task was another wiki, one that related to a grammar point - conditionals. The idea was to compile a list of example conditional sentences found in any texts related to their profession available online (from newspapers, magazines, journals, blogs, advertisements, etc.) and they were asked to make note of the source where they had found the example sentences (and add a hyperlink). The purpose of this task was to connect a grammar and a vocabulary topic so that the 
students would become exposed to new vocabulary while trying to find the required grammar constructions. In addition, this task was also used to expose students to a larger vocabulary input while working on grammar and thus incidentally learning vocabulary.

The third and final task was to create a glossary that could be used by the students of the particular profession even after they would have passed the exam. The students were asked to go through the teaching materials that were uploaded on Moodle during the semester, select words related to their profession, add them to the glossary and give their translation in Croatian. If they thought that a translation that somebody else had written was not satisfying, they could give their own translation with an explanation why that one was better or more appropriate. The purpose of this task was to use the acquired vocabulary knowledge and contrast and compare it to their mother tongue. The reason why translation was used instead of asking students to explain and describe the meaning of the chosen words in English was to give an opportunity even to those learners whose language level was lower and for whom this would be quite a demanding task to perform.

The students of the FtF groups were informed of what their colleagues were doing and the output was shared as an example of additional learning material. Unfortunately for this study, student logs were automatically deleted when the academic year ended (on 31 September). The author of this study was not familiar with that procedure and did not save their logs which would have provided detailed information on the precise data with regard to individual students' activity. Nevertheless, by gauging the students' engagement with Moodle during the study, based on the 'history' tab available in Moodle and on the outcome of the tasks created during the testing period, it is possible to obtain information on their activity related to the tasks and therefore make some conclusions related to their autonomy. Logs were used by the teacher before the final lesson to determine whether the students' activity was sufficient to fulfil the required obligations of the course that then enabled students to take the exam. As noted in the literature, glossaries are useful in education, but can be quite challenging as an activity which requires students' dedication and time and sometimes an additional incentive and support by the teacher (Breeze, 2014; Hirschel, 2012; Ratz, 2016; Stanley, 2007). 
To sum up, the students worked together on the vocabulary that was taught during the lessons, but had the opportunity to enrich their vocabulary by accessing additional, ideally comprehensible input. While searching the net and reading about the topics of their interest they had the opportunity to come across language not controlled by the teacher and therefore had the opportunity to learn new vocabulary, outside their formal learning environment. In this way, the students are exposed to comprehensible input that can hopefully be expected to turn into intake. By becoming aware of new words or other new linguistic information which can be noticed by its use in a new linguistic situation, the vocabulary they choose to write down in the glossary can be perceived as intake. If this process is successful and they try to learn the words and use them in new linguistic situations, the glossary can then be perceived as the output.

The three tasks previously mentioned had an additional purpose alongside enriching students' vocabulary, namely to support collaborative learning and raise awareness of autonomous learning. By working together to create useful learning content, the students could share the knowledge with their peers and make it a resourceful material for the final exam. In order to foster learner autonomy, as mentioned in the previous paragraph, it was expected of the students in the BL group to take greater control of their own learning. By analysing their activity through the 'history' tab, it was possible to obtain information on their activity related to the tasks and therefore make some conclusions related to their autonomy. In addition, the information collected was used to assess their autonomy by looking at how many times they were actively involved in completing the tasks.

Learner autonomy was observed for the purposes of testing the second hypothesis, which states that blended learning raises students' awareness of the possibility of more autonomous and independent English language acquisition in relation to traditional classroom learning. In order to make students aware of their language acquisition, the students of the BL group were asked to selfassess their English language knowledge using the European Language Portfolio (ELP) and its can do statements - the language biography component, which provided a reflective accompaniment to the process of learning and using second languages (Little, 2002) at the beginning and the end of the semester (see Appendix E). The students of the FtF group performed the self-assessment analysis only at the beginning of the research. The reason for administering the self-assessment 
sheet only to the BL group twice during the semester was that it is the blended learning environment which presupposes more autonomous learner activities than the regular face-to-face environment. Therefore, it is expected of learners in a blended learning environment when being engaged in online activities to become aware of the progress they are making during the semester. Their results were used to compare their self-assessment and objectively tested knowledge of the English language.

In addition, the data collected at the pre-test point of measurement collected from all the students were used to see whether there was an association between students' language competence selfassessment (measured with the help of the ELP) and the online level test that students had to take to be placed in the two groups. The self-assessment composite score was calculated as follows:

(1) for each skill (reading, writing, listening and speaking) and each competency level (A1-C2), the proportion of ticked items was calculated;

(2) the proportions for each skill were then summed up to create a total for each separate skill;

(3) those totals were then summed up to create the total composite score.

For example, if a student checked 4 out of 4 items regarding listening at the A1 level, 6 out of 6 at the A2 level, 6 out of 6 at B1, 4 out of 6 at B2, 2 out of 6 at $\mathrm{C} 1$ and 0 out of 1 at $\mathrm{C} 2$, their total listening skill score 4 . This was calculated as follows:

$$
\begin{aligned}
& 4 / 4(\mathrm{~A} 1)+6 / 6(\mathrm{~A} 2)+6 / 6(\mathrm{~B} 1)+4 / 6(\mathrm{~B} 2)+2 / 6(\mathrm{C} 1)+0 / 1(\mathrm{C} 2)= \\
& 1+1+1+0.67+0.33+0=4 .
\end{aligned}
$$

This was repeated for each skill, and the skill totals were then added up.

The students also rated their personal language attainments, which enabled them to reflect upon the value of their learning activities (see Benson, Grabe, \& Stoller, 2001) and thus provided useful data on learner autonomy. The collected data was analysed using the statistical computing language $\mathrm{R}$ and compared with regard to the differences in the self-perception of their skills (knowledge). This provided useful information regarding the hypothesis regarding the correlation of the effect 
that blended learning approach has on ESP vocabulary acquisition and the students' selfassessment of their linguistic competence with the skill of using the blended approach.

For the purpose of testing the third hypothesis - stating that the effect of blended learning on the acquisition of ESP vocabulary and the level of students' self-assessed competence is related to the students' skill of using a blended approach to learning (their technological skills and the use the technology for learning purposes) - the results were based on the professional vocabulary score and the data obtained by the first section of the questionnaire mentioned earlier in the text, that is, the questions in which refer to the CMC competence of students. Using blended learning environments presupposes that learners have the appropriate technology skills to follow the course. Since in this study the blended learning approach is compared to the traditional face-to-face approach to learning, this served as a good starting point for shaping conclusions based on their comparison. Since the professional vocabulary test has been described earlier in the text, the following paragraphs will describe the first section of the questionnaire in more details since the data collected by the questionnaire had a multiple purpose: to test the hypothesis and to supplement the conclusions about the blended learning group.

As mentioned earlier in the chapter, alongside the professional vocabulary test, at the beginning of the semester, the students in both groups were given the questionnaire (see Appendix F1). The questionnaire was administered once again to the BL group with additional questions in the posttest stage (see Appendix F2). The reason for this decision was that for the FtF group no changes were expected regarding their use of technologies and Moodle or their CMC competence in the post-testing phase due to the fact that it was not required of them to use technology for language learning. On the other hand, the competence of the BL group was expected to be different in the pre- and post-stage testing. With this in mind, the data needed to be analysed in the following way: in the pre-testing and post-testing phases jointly (for both groups) to see the general view on the topics of research interest; separately for the FtF group compared to the BL group in the pre-test stage to notice any differences at the beginning of the study; and only the BL group comparing the pre- and post-test stage since it is of interest to see how the use of technology affects this group and how they perceive the experience of learning in a blended environment. 
The section of the questionnaire with regard to the demographic data of the participants has already been described. The remaining four sections dealt with students' general perceptions of their use of technology in general and CMC tools in particular for private and academic purposes, data about the technology skills of the students, their attitude towards using technology for language learning and using the Moodle platform, and general attitude towards e-learning.

The first section of the questionnaire, as the section important for testing the third hypothesis, was based on an existing survey (Spitzberg, 2006) and had been adapted to the needs of this research. The section refers to the students' perception of their general competence of computer-mediated communication. The students self-assessed their general competence of computer-mediated communication by indicating their answers to nine questions using a 5-point Likert Scale with a range of answer options where $1=$ not at all and $5=$ very much. The questions were related to their motivation to use $\mathrm{CMC}$ in interaction with others, their knowledge of CMC, efficacy and efficiency/productivity and general usage/experience. The answers were analysed and mean values for each of the questions were calculated and analysed using the statistical computing language $\mathrm{R}$ (R Core Team, 2017) and compared to their scores on professional vocabulary test in order to determine if there is an association between the online group's technological competencies and their post-test professional vocabulary scores.

In addition to the statements which refer to different constructs needed for CMC competence to develop (e.g. motivation, knowledge, skills, efficacy, etc.), other questions were added to ensure that the picture of the role that technology has in students' lives would be more complete. The more competent the students are using technology, the easier it is for them to concentrate on other aspects that relate to their learning. For that reason, it seemed interesting to find out which of the CMC tools they use most frequently and how comfortable they feel when using them. This particular piece of information will shed some light on which CMC tools student prefer using.

The second section of the questionnaire contained questions about using technology in its many forms for academic purposes. The questions ranged from enquiring about which of devices students used for academic purposes and how often and their general experience with e-learning courses, over communication with peers and teachers in an online environment and using social networks 
for that purpose, to their general perception of technology for academic purposes. This enables gaining an insight into the importance technology has in their academic surroundings.

The third section consisted of questions referring to the use of Moodle: how competent students felt using it, how often they used it and for what purposes, whether they liked using it, their perception of its usefulness for learning and their production, their readiness to use it for language learning, but also how easy it was for them to use it and whether it made learning interesting. the answers to these questions seem as valuable information on whether Moodle is appropriate environment for blended learning from the students' point of view.

The remaining section of the questionnaire is students' general attitude towards distance/e-learning and their experience of learning in a blended learning environment. This section contains six additional questions that were added to the post-test stage, when administering the questionnaire to the BL group.

The series of questions that had to be answered by 'yes' or 'no' that refer to online environment, provide insight into the general attitude students have with regard to learning an online environment. They include two questions which refer to skills students perceive as skills that can be developed in an online environment. This is useful so as to see whether they perceive online environment as an environment in which all the four skills can be developed.

The final six questions of the questionnaire that were added in the post-test stage referred to particular characteristics of the blended learning environment that might have affected their attitude towards blended learning and face-to face learning environments. The background for asking these additional questions can be found in the teacher's aspiration towards finding out about the differences the students noticed in comparison to the traditional way of learning. The questions referred to the lack of their physical presence in the classroom, the lack of regular face-to-face contacts with the teacher, their views on whether their English language knowledge had improved, whether they had obtained better information with regard to the learning environment. The final two questions which directly asked about the students' view on learner autonomy development in 
the blended learning environment, and how important it was to determine their own studying dynamics could be used to additionally confirm or reject the second hypothesis.

All the answers to the questions in the questionnaire were analysed using the statistical computing language R (R Core Team, 2017) by applying the corresponding metrics.

In this chapter, upon describing the structure and distribution of participants into groups, the methodology for this study has been presented and discussed in detail through describing activities, tool and instruments used in this research based on dependent and independent variables. The reasons for their choice have been stated and their purpose has been explained in details. The data gathered has been analysed and the results will be presented in the next chapter. 


\section{RESULTS AND DISCUSSION}

This chapter will be organized to follow the previous chapter, Methodology, so as to remain in line with the dependent and independent variables. For that reason, the focus will sometimes be placed on the data collected by more than one instrument and thus hopefully give a clear image of what has been investigated in this study, how and for what purpose. Results of the research will be presented and discussed in the same chapter due to the nature of research and the amount of collected data.

The demographic details and characteristics of the participants that were obtained by the questionnaire have been described in details in the previous chapter. The demographics of the study has shown to represent the population of students at higher-education technical institutions in Croatia - their average age is around 20 and they have been learning English for approximately nine years. Their English language knowledge is at intermediate/advanced level and therefore they should not have problems following the content of the English language subject in an ESP course.

Other details that could be found in the questionnaire in the pre-testing and post-testing phases that are of crucial significance for the hypotheses will be analysed jointly (for both groups), separately (FtF group compared to BL group in the pre-test stage) and only for the BL group comparing the pre- and post-test stage. Some of the results will be presented in charts and figures when it will be deemed necessary and sometimes only generally when the differences between the results will not differ significantly.

As previously mentioned, the aim of the study was to investigate three main points of interest: to find out whether there was a difference between the participants placed in the FtF group and the ones placed in the BL group with regard to their vocabulary learning; whether there was a change of perception of more autonomous learning between the first and the second point of measurement in the BL group, by examining their ESP self-assessment results and through specific questions of the questionnaire; and whether the students' language competence as assessed by themselves on the ELP and their vocabulary acquisition was related to the blended approach to learning. For that purpose, several instruments were used and have been described in Chapter 5. 


\subsection{Learning Environment and Vocabulary Acquisition}

The first assumption was that the students could acquire vocabulary in a blended learning environment to the same extent as in a face-to face environment. The basis for the vocabulary assessment consisted of a Vocabulary Levels test and a professional vocabulary test designed by the teacher on the basis of the material used in teaching, covering the obligatory programme of the English Language course and representing the main part of the regular final semester exam. The topics in the test related to the vocabulary of a particular profession/study programme and contained three different types of activities (gap filling, true/false statements and translation) described earlier in the chapter. Students were awarded points for correct answers only (spelling mistakes were not tolerated). The answers were linguistically analysed and the results were compared regarding the type of learning (face-to-face and blended) and added to the final vocabulary score.

To test whether there is a differential effect of the type of teaching (face-to-face vs blended) on professional vocabulary acquisition, a robust ANOVA for mixed designs was conducted (Field, Miles, \& Field, 2012; Wilcox, 2012). This was done because the assumption of normality (tested with the Shapiro-Wilk test) was violated for the online group, both in the pre-test ( $W=0.91, p<$ $0.01)$ and in the post-test $(W=0.94, p=0.013)$.

The robust ANOVA was conducted using the bwtrim function from the WRS2 package $^{14}$, with the trim level for the mean set to $20 \%{ }^{15}$. There is a statistically significant difference in test scores between the first and second administration of the professional vocabulary test $(Q=26.71, p<.01)$ - the students' mean score was higher on the post-test $\left(M_{\text {trim }}=14.12, S D_{\text {trim }}=4.32\right)$ than on the pre-test $\left(M_{\text {trim }}=11.5, S D_{\text {trim }}=5.31\right)$. This main effect is expected and most probably represents the effect of learning which occurred between the first and second point of measurement, at the beginning and at the end of semester (Figure 4).

\footnotetext{
${ }^{14}$ https://cran.r-project.org/

${ }^{15}$ Trimmed means provide a better estimation of the location of the bulk of the observations than the mean when sampling from asymmetric distributions; the standard error of the trimmed mean is less affected by outliers and asymmetry than the mean, so that tests using trimmed means can have more power than tests using the mean. (https://garstats.wordpress.com/2017/11/28/trimmed-means/)
} 


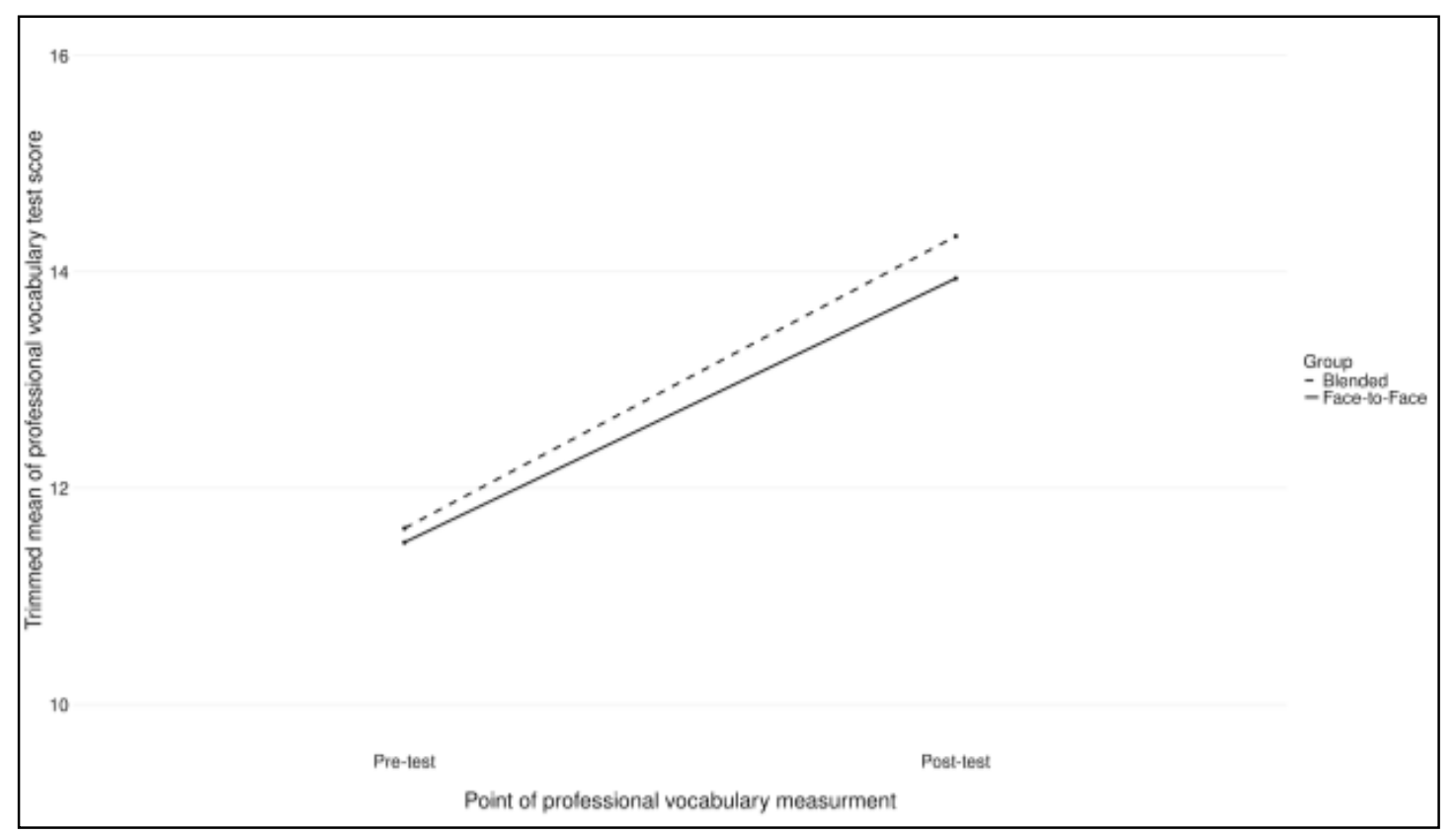

Figure 4. Pre- and post-test scores on a professional vocabulary test for BL and FtF groups

The main effect of teaching method was non-significant $(\mathrm{Q}=0.1, \mathrm{p}=.75)$, as well as its interaction with teaching itself $(Q=0.07, p=.8)$. This leads us to conclude that there is no evidence that would imply that one of the teaching methods leads to a better learning outcome than the other (see Table 1).

Table 1. Descriptive statistics divided by group and point of measurement (PoM)

\begin{tabular}{llrrrrrr}
\hline Group & PoM & $\mathrm{M}$ & $\mathrm{M}_{\text {trim }}$ & $\mathrm{SD}$ & $\mathrm{SE}$ & Skew & Kurtosis \\
& Pre-test & 11.3 & 11.5 & 4.35 & 0.56 & -0.29 & -0.07 \\
FtF & Post-test & 13.68 & 13.94 & 4.84 & 0.62 & 0.27 & 0.62 \\
\hline \multirow{2}{*}{ Blended } & Pre-test & 12.06 & 11.63 & 5.59 & 0.81 & 1.27 & 3.84 \\
& Post-test & 14.29 & 14.33 & 5.26 & 0.76 & 0.66 & 2.48 \\
\hline
\end{tabular}


One of the research foci was whether it was possible to acquire professional vocabulary in a blended learning environment to the same extent as in a traditional, face-to-face classroom. This was encapsulated in the first hypothesis, which suggested that blended learning of ESP vocabulary has the same effect on vocabulary acquisition as face-to-face learning. Upon analysing the results obtained by the general and professional vocabulary test, the face-to-face group and the blended group were compared regarding the type of learning. This comparative analysis allows conclusions to be drawn regarding the first hypothesis. The study with its results has shown that professional vocabulary can be acquired in a blended learning environment to the same extent as in a traditional learning environment. Moreover, as has been mentioned earlier in the thesis, blended learning is an excellent approach to ESP due to its availability and/or flexibility, including its use for supporting autonomous learning (Banditvilai, 2016; Chirimbu, \& Tafazoli, 2014; Dziuban, Moskal, \& Hartman, 2005; Fučkan Držić, Seljan, Mihaljević Djigunović, Lasić-Lazić \& Stančić, 2011; Lungu, 2013). The positive effect of blended learning on vocational vocabulary has already been presented earlier (Lesiak-Bielawska, 2012; Tosun, 2015). The results that the students achieved during vocabulary testing in this study have shown that students in both groups acquired vocabulary, even though the blended learning group was working on vocabulary without being present at the lessons for $80 \%$ of the time. This is in accordance with the literature which claims that the effectiveness of blended learning is similar to the effectiveness of face-to-face learning (Means, Toyama, Murphy, \& Baki, 2013).

It is interesting that the students in the blended learning group did not feel they improved their language, even though their results were slightly better than the results of the FtF group. Maybe they did not improve their overall level (which is almost impossible after 30 lessons in a semester), but they acquired new vocabulary, which is recorded in the results of the study. Students placed in both groups managed to acquire vocabulary while different approach in teaching was used. There is no evidence to show that one of the groups achieved significantly better results, which is in accordance with the literature (Larson \& Sung, 2009; Lim, Morris, \& Kupritz, 2007).

It is worth mentioning that by changing the learning environment the type of interaction changed. In a traditional classroom the emphasis is placed on an interaction between a learner and a teacher 
or between two (or more) learners, whereas in a blended learning environment interaction between a student and a computer is in focus (compare Chapelle, 2005). By changing the environment, the way we learn changes. In addition, language is not the only tool used for mediation: computer is an additional asset. It has been previously said that, according to sociocultural theory, that the same activity can be realized through different actions and with different forms of mediation (Lantolf, 2000). By learning in a blended learning environment students have the opportunity to use different forms of interaction with and via computer (glossary has shown to be a good example of this kind of interaction) and they can interact as many times as needed; this is not always the case in faceto-face communication. In line with this, while learning in a blended learning environment, learners are able to have the time needed for them to mediate their own learning to reach self-regulation which teachers should take into consideration. This study has shown that even without the direct teacher's assistance they can acquire vocabulary by using computer as a mediating tool.

\subsection{Vocabulary Acquisition and Learner Autonomy}

An additional aim related to vocabulary acquisition was to ensure that the students working in a blended learning environment were exposed to professional vocabulary to a sufficient extent. With that in mind, they were asked to collaborate on three activities during the semester that would encourage reading on the topics that were discussed at the lessons in the face-to-face environment.

Wikis and a glossary represented activities which the teacher suggested doing as part of the course, but they were still done on a voluntary basis. Since no logs were available at the time of analysing the data (due to the events described earlier in the text), 'history' was used to check the participants' activity. The first task was to create a wiki on a given topic closely related to the students' profession. The creation of the first wiki was limited only by the topic - each programme group had a different topic that was closely related to their profession and to the topics that were presented and discussed at FtF lessons. Even though they worked with different topics, their results were analysed as belonging to one, the BL group. Each study group created their own wiki. Figure 5 presents a part of the text that was created by Mechanical Engineering students. 
Every material has specific properties whether we are talking about its general, mechanical or thermal properties. Every material can be described and used for different purpose based on its properties. engineering materials:

1.metals(a.ferrous, b.non-ferrous)

2.composites

3.non-metals(a.ceramics, b.composites c.polymers(c1.rubber, c2.plastics(c21.thermoplastic, c22.thermosets))). Materials that burn easily are combustible, and materials that do not burn are fire-resistant(non combustible) Metals, rocks, glasses, sand, and iron fillings (magnetic) are some examples of non-combustible materials. When material is put under any type of stress, it will suffer some deformation. The deformation may be permanent, or may be reversed when the compression forces disappear. Therefore, a material ability that allows the machine part to return in original shape after the force stopped act is called elasticity. This ability is checking by experts on special machines ( tensile testing machines for example look the- $h$ ttp: :/wiki.answers.com/Q/What does a tensile testing machine do\&src=ansTT). The result of this tests is a stress-strain graph which engineers and other experts of metallurgy are using for calculations, reading different material properties, identifying critical points and so on... The mechanical properties of metals determine the range of usefulness of a material and establish the service life that can be expected. Mechanical properties are also used to help classify and identify material. The most common properties considered are strength, ductility, hardness, impact resistance, and fracture toughness. Most structural materials are anisotropic, which means that their material properties vary with orientation. Mechanical properties are generally specific to product form such as sheet, plate, extrusion, casting, forging, and etc. The mechanical properties of a material are not constants and often change as a function of temperature. For example, temperatures below room temperature generally cause an increase in strength properties of metallic alloys; while ductility, fracture toughness, and elongation usually decrease. Temperatures above room temperature usually cause a decrease in the strength properties of metallic alloys. Ductility may increase or decrease with increasing temperature depending on the same variables.( http://www.ndt-ed.org/EducationResources??/CommunityCollege??/Materials/Mechanical/Mechanical.htm)

STRENGTH- the greatest stress that the material can withstand prior to failure. DUCTILITY- a material property that allows it to undergo considerable plasticdeformation under a load before failure. ELASTICITY- a material property that allows it to retain its original dimensions afterremoval of a deforming load. STIFFNESS- a material property that allows a material to withstand high stress withoutgreat strain.

Figure 5. Part of the text created by Mechanical Engineering student(s)

All together there were 230 interventions in the wiki, from adding an initial draft to its modifications (e.g. changing the order of the sentences in the wiki based on the text added, changing the text colour, changing the fonts). 62 students were involved in this, which means that there were 3.7 interventions per student. As expected, not everybody participated and contributed to the same extent. Since there were 84 students in the BL group, not everybody took part in creating the wikis $-73.80 \%$ of students were active. Some students invested more of their time and intervened more often than others by adding a sentence or a paragraph more than once, on different days. One student added content 21 times. When analysing the texts, it can be said that the task was accomplished since the resulting content was exactly what had been required (to summarize what had been taught in the previous lessons on the topic related to their profession by writing their own sentences/explanations/descriptions of the topics and adding links to some webpages that cover the topics and at the same time including the most important vocabulary (words and their 
definitions) from the lessons published on Moodle. It was noticed that the students did not correct or modify the content published by other students - only the position of the sentences in the wiki was changed several times, probably to better agree with the text. In most cases, the content was not edited even though the students were encouraged to edit the text according to the best of their knowledge and skills and at a point in time when they were able to - there was no time limit to the activity so the final change was made in the last week of the semester.

Therefore, it can be noticed that students' activity in the creation of the first task was satisfactory, with the majority of them being involved in the task. However, as could be perceived based on the results, not everybody was engaged in the activity to the same extent, neither on the group nor on the individual level. Some students added only several sentences or one short paragraph, while others worked on the same paragraph more than once to improve it, for example changing the sentence order in the text and even playing with fonts and style.

Upon analysing the average number of words per group, the students of Technical and Economic Logistics added the highest number of words per student This is mainly due to the activity of one student studying Logistics who added 80 words (50\% of all the words added by Logistics students). The smallest number of words was added by the students of Multimedia, Design and Application. From my perspective as a teacher and interpreter, the reason for that might even the fact that area of multimedia is the rather challenging area when it comes to translation from English - most of the words do not even have their translation in Croatian but are used in their original English form.

Another issue has been noticed: the students edited their own text only, even though they were encouraged by the teacher to feel free to make any necessary changes to the content added by their colleagues. It can only be assumed why they did not intervene with the text created by their colleagues - they did not feel it was theirs to do so, or they 'did not want to hurt anyone', which was the answer given by one student when asked why nobody edited another person's content. It would be very useful to carry out a study in relation to this issue in order to come to firmer conclusions and not only assumptions. 
Nevertheless, the task was completed and the output of their activity has shown to be representative material available to the students based on the topic of their interest. The materials that they collected and/or created were in accordance with the task for each study programme and contained relevant content. The content was edited even towards the end of the semester, with final changes made in the last week of the semester. This suggests that the students were aware of the possibility to work on the wiki even when other tasks were active. Since wikis have shown to encourage collaboration due to their simple use and for students having the chance to develop their technology skills and improve their language, especially writing skills (e.g. Bobera, Sakal, Tumbas and Matković, 2014; Cilliers, 2016; Chu, et al., 2017; de Almeida Mello, 2017; Goertler, 2009; Lund, 2008; Miyazoe \& Anderson, 2010; Papadima-Sophocleous, 2012; Vurdien, 2017; Wang, Zou, Wang, \& Xing, 2013).

The second wiki was closely related to the grammar topic of conditionals, where students were invited to create a compilation of conditional sentences they found in various available texts related to their profession (from newspapers, magazines, journals, blogs, advertisements, etc.). In this way, the students were able to make use of their extra-linguistic knowledge and apply it while focusing on English grammar, conditionals in specific. At the same time, they were once again exposed to language which is not directly connected to their formal learning environment. They read texts that were related to the topics of their profession/study programme. In addition to compiling the sentences, they had to add a link to explain where they found the sentence. The idea was to ensure the students received comprehensible input with regard to vocabulary while reading about their profession and being focused on grammar. Their extra-linguistic knowledge of the topic helped them choose the appropriate sentence that would fit the requirements of the task (related to their profession). The examples that they included in the wiki were found on different websites - from purely educational ${ }^{16}$ to commercial ones ${ }^{17}$. Students were able to recognize the type of content needed for the activity and its grammar purpose.

\footnotetext{
${ }^{16}$ e.g. http://www.physicsclassroom.com/class/thermalP/Lesson-1/Rates-of-Heat-Transfer

${ }^{17}$ e.g. http://www.tomshardware.com/news/asus-strix-graphics-280x-780,26861.html
} 
The final output was a list of 150 conditional sentences added by 52 people, which could be expressed as 2.89 sentences per person. A chunk of the list can be seen in Figure 6.

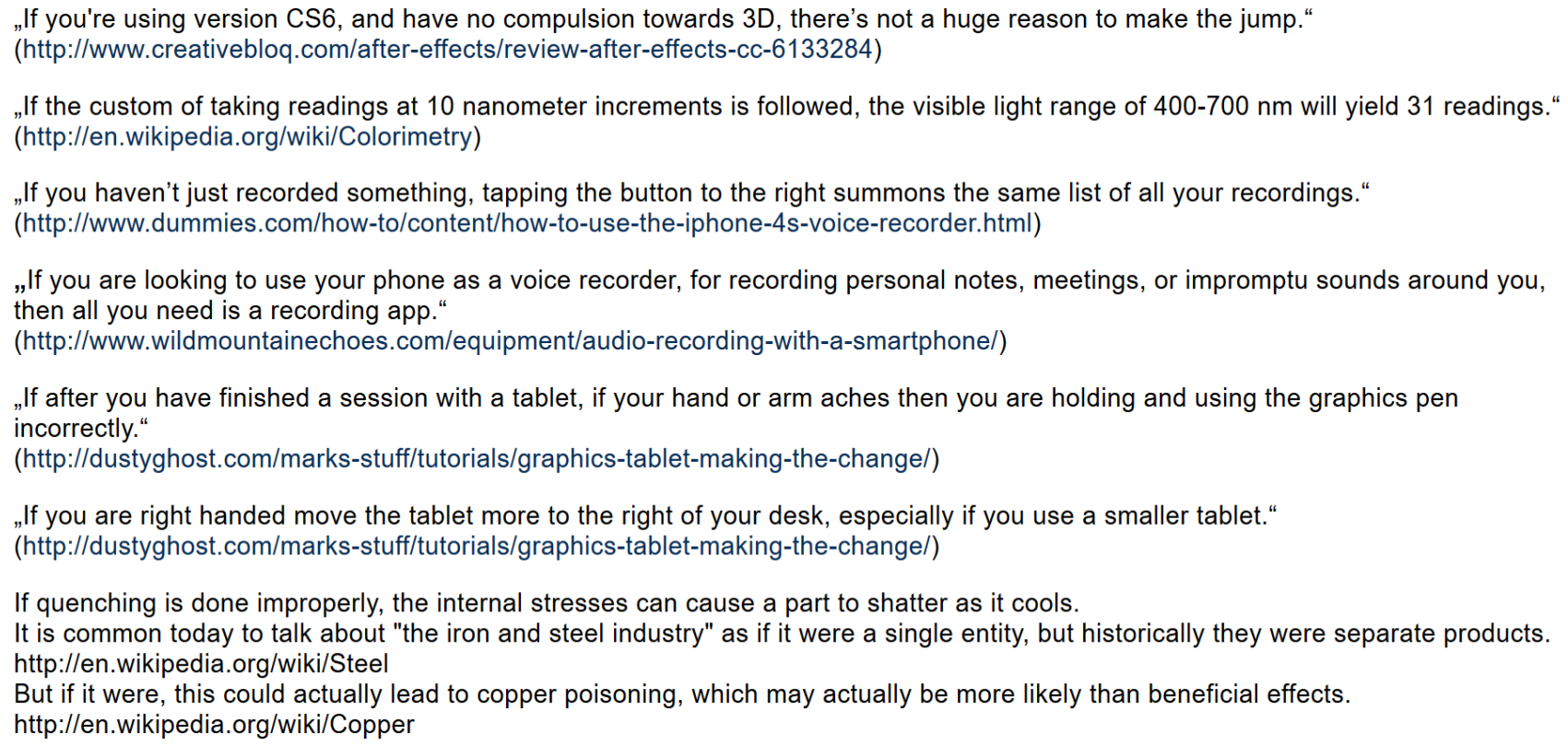

Figure 6. Example sentences added by students as part of the second wiki task

However, just like in the first task, there were a number of students (16 of them) whose activity was minimal and who added only one sentence each; there were six students who added more than five sentences; and the highest number of sentences added by one student was ten. This list that the students created can be used by the teacher when teaching the topic of conditionals or in the final test, allowing them to give real examples found by the students.

It could be argued that the second wiki was quite successful. Maybe the reason for that is that it was an easier task and therefore more attractive for the students. In addition, they were exposed to additional input in terms of professional vocabulary. Some of the sentences chosen by the students were later used as part of their final exam, as part of the task that assessed their use of conditionals. 
However, the examples were not included in the test that was used in the study, but only in the regular exam they had to take in order to pass the course. This task showed again that the students' activity was lower than expected with regard to the number of them who created the wiki. However, since they were not required to add a particular number of sentences into the wiki, it could be said that the task was successful. The fact that $61.9 \%$ of them were involved in the creation of the task leads to the conclusion that their activity in this task was lower when compared to the previous wiki. Nevertheless, the students who did engage with the task were able to recognize both the grammar form and vocabulary related to their profession.

The third task was quite a productive one in which the students created a glossary of the terms related to their profession. There were 813 words and expressions in English which the students chose and translated into Croatian, that being 9.67 words per student. An example of the list created by Multimedia students can be seen in Figure 7. 


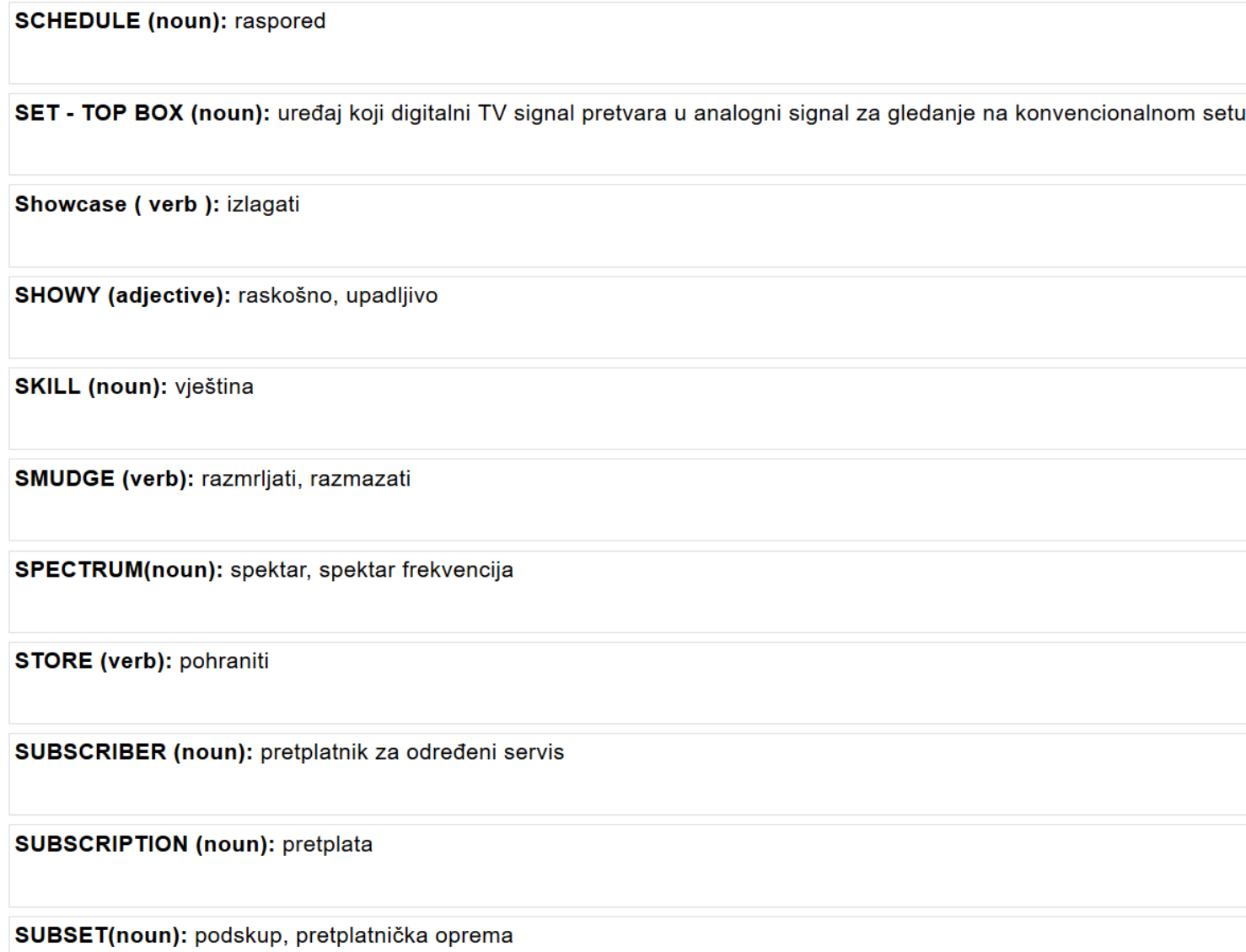

Figure 7. Example words added by the Multimedia students as part of the glossary

The teacher checked the translations to make sure that no mistakes had been made. Here it is worth mentioning that the topics that the words belong to are all the topics covered in the lectures that were held in a traditional face-to-face environment. It is interesting to see the difference among the students of different study programme in terms of the amount of work they did in creating their glossary. This is the only point where the difference between the activity of the students was quite noticeable (Figure 8). It can be seen that Mechanical Engineering students created the largest glossary, while the glossary of the Civil Engineering students was the smallest. 


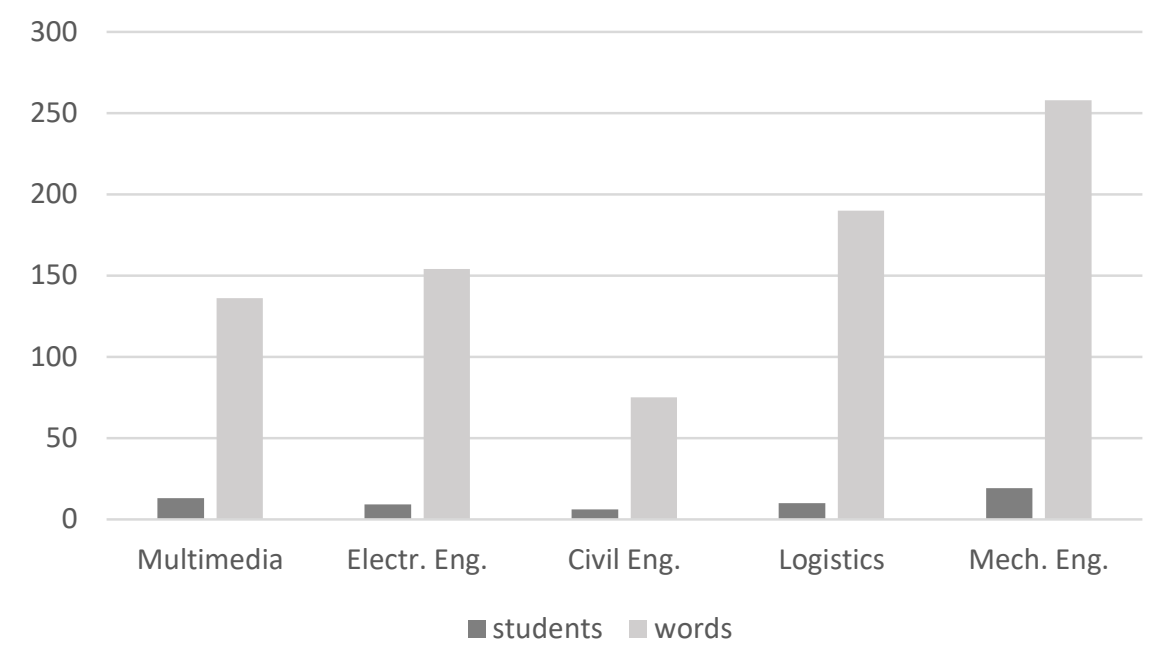

Figure 8. The number of students and words they added to the glossary

If the average number of words is analysed per group, the students of Technical and Economic Logistics added 19 words per student. This is mainly due to the activity of one student studying Logistics who added 80 words (50\% of all the words added by Logistics students). The smallest number of words was added by the students of Multimedia, Design and Application (Figure 9).

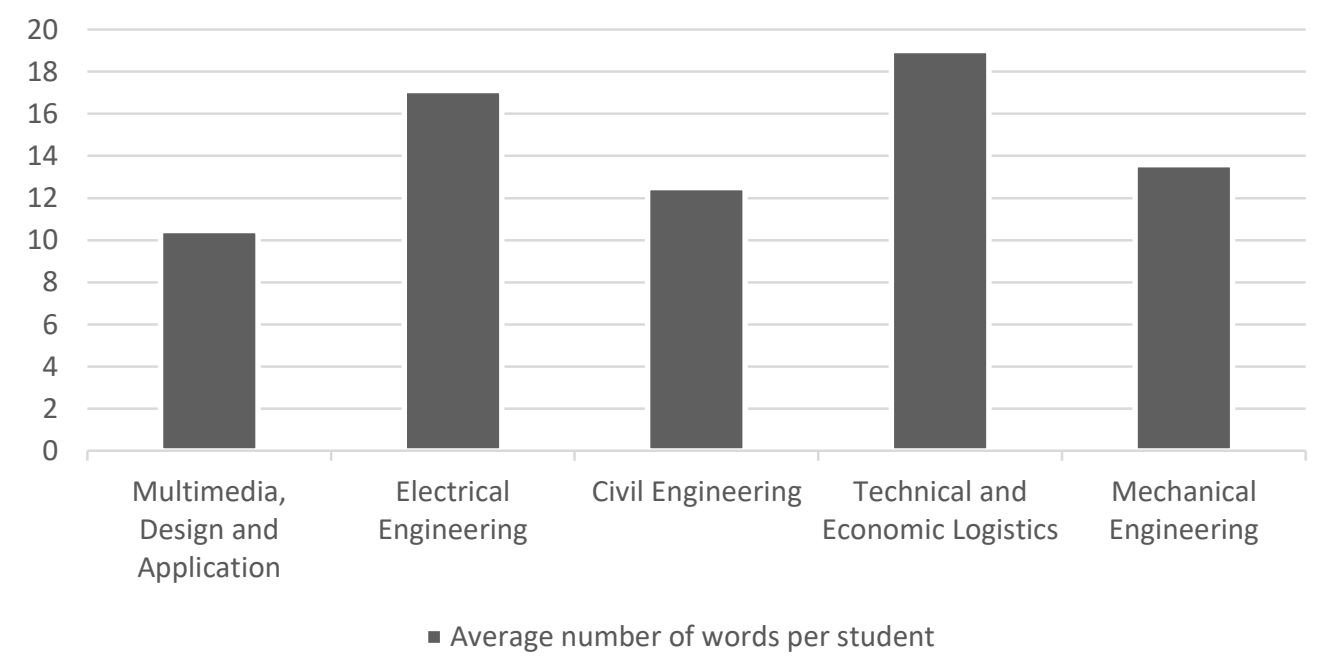

Figure 9. Average number of words per students with regard to the study programme 
The third task - creating a glossary - indicated to an increased activity of individual students involved in the task. Their activity was higher when compared to the second wiki, but lower than in the first one. In the glossary activity, some extremes regarding the students' engagement were noticed: there were two students who added only one word, and there were individuals who added a significantly higher number of words, with the highest being 80 . It could be assumed that certain participants liked the task and invested their time and effort into creating a useful list. One comment by a student was that this had become his preferred method of learning unknown words related to his profession since the task had been to translate the words into Croatian.

The students had been instructed that the words in the glossary should not be repeated. Therefore, before writing down a word, the student had to check all the words that had been added before. This ensured additional input while performing the task because the translations were already visible. The glossary turned out to be a good reference point for studying vocabulary. This relates to the fact that studies have shown that L1 helps in vocabulary acquisition and L1 has a facilitative role in general English (Goundareva, 2011; Liu, 2008; Pakzadian, 2012) and in ESP (Kavaliauskienë, 2009; Kavaliauskienë \& Kaminskiene, 2007; Garcia, 2018). For this reason, the students in the $\mathrm{FtF}$ group were invited to use it as a source to prepare for the exam. Unfortunately, no feedback was received on whether the students used it. The important aspect is that the words that were tested in the professional vocabulary test were also found in the glossary, which leads to the conclusion that the students perceived which key words were related to their professional vocabulary and therefore needed to be learned. It can be concluded that this contributes to other research that has shown positive impacts of using glossary in language learning in a blended learning environment (Breeze, 2014; Hirschel, 2012; Ratz, 2016; Stanley, 2007). In addition, the results have shown that new vocabulary can be acquired when learners encounter it in a familiar context, for example when it is thematically related to their study programme. This helps learners rely on familiar foreign vocabulary items within a familiar context, which can help in acquiring new vocabulary (see Ahmad, 2012; Hunt \& Beglar, 2002; Nation, 2015). If students in a blended learning environment are exposed to new linguistic items that are integrated in reading tasks about a familiar topic in a foreign language, their retention will be higher (Alali \& Schmitt, 2012; PellicerSánchez, 2016; Restrepo Ramos, 2015; Vidal, 2011). 
As regards wikis and the glossary, it can be concluded that the students were successful in their tasks of creating them. Some were more and some less active in doing it. Nevertheless, they managed to create useful learning materials that dealt with topics related to their profession and grammar lesson on conditionals. These materials can be used not only by them and their colleagues, but for generations to come. The students' work on wikis and glossary has shown to be useful for vocabulary acquisition with the blended learning group as an input they received as a compensation for not being present at the lessons. Even though they did not attend lessons, they managed to acquire professional vocabulary. This speaks in favour of using LMSs in general since the literature has shown that vocabulary can be fostered using the affordances of technology, without strictly requiring face-to-face interaction (García-Sánchez, 2016; Ratz, 2016) or the presence of a teacher (Chiu, 2013).

Based on these three tasks - two wikis and a glossary - the students became familiar with two different activities offered by Moodle, activities which enable student collaboration for the purpose of creating content needed for vocabulary development, thus also helping students to pass the exam and successfully complete the course. By reading the texts, paragraphs, or sentences as part of their obligatory lesson, they had the opportunity to focus on the meaning of particular words in Croatian. While there were different levels of engagement in the activities, the students managed to create useful content related to their profession which potentially served as a good source for learning vocabulary. In addition, in these activities, interpersonal and intrapersonal interaction (see Chapelle, 2005; Trawiński, 2005) have been noticed: the students were working both on their own and collaborating with their peers using computers.

Students have at their disposal related content created by their peers, and are able to use it for learning vocabulary. Using CMC in most of the cases implies working without the direct teacher's presence - here a parallel can be drawn to self-access centres, where students have the opportunity to choose their learning materials and in this way foster their learner autonomy, which confirms that CMC is an excellent way of promoting learner autonomy (Fisher, Evans \& Esch, 2007). Wach (2012) has shown in that if learners are willing to use CMC for the purposes of language learning, $\mathrm{CMC}$ has great potentials in language learning. CMC applications have shown to be efficient in 
giving learners more control and autonomy over their own learning (Chapelle, 2001), which supports White's (2003) claim that learner autonomy is a crucial notion regarding computermediated learning. There has been evidence that CMC is an excellent way of promoting learner autonomy Fisher, Evans \& Esch (2007). With this in mind, it was expected that the students in the BL group would take greater control of their own learning and work without the direct teacher's presence. For that reason, the information collected for the purposes of the study was used to assess their autonomy by looking at how many times they were actively involved in completing the tasks set by the teacher. Since the tasks were to be completed voluntarily, students' activity could be interpreted as an act of autonomous learning encouraged by using CMC tools. The students' engagement in these activities was visible in their active participation in the creation of learning materials related to their professional vocabulary. However, even though learners successfully completed the tasks in a blended learning environment, they did not necessarily do so because they were aware of the potential that $\mathrm{CMC}$ tools offer. If it is in our interest to encourage learners to become autonomous, it is important to make them aware of the potentials that technologies offer so they can use them for language learning in a specific context. In this way, learners are able to choose specific online content that contributes to their language improvement. This means that they are ready to use a particular type of technology in accordance with a particular language learning purpose (Trinder, 2017). In addition, even though this study has confirmed that not everybody is ready to actively engage in working on the set activities, for many learners developing learner autonomy in ESP is more than welcome due to the increasing need for life-long learning (Ajideh, 2009; Belcher, 2013; Gardner, 2007; Xu, 2012).

\subsection{Blended Learning and Autonomous Learning}

The second hypothesis states that blended learning raises students' awareness of the possibility of more autonomous and independent English language acquisition in relation to traditional classroom learning. In order to test the hypothesis, it had to be investigated whether there was an increase in students' self-assessment values on the English Language Portfolio (ELP) scale between the two measurement points - at the beginning and at the end of semester. For that purpose, a Wilcoxon signed-rank test was conducted. The analysis included only students in the blended learning environment, since they are the only ones who have rated themselves at both points of 
measurement. Wilcoxon's signed-rank test was chosen because the assumptions of the dependent t-test were not met. The test failed to find a statistically significant difference between the two points of measurement $(1 \mathrm{st}$ point median $=15.8,2$ nd point median $=17, \mathrm{~V}=56, \mathrm{p}=.85)$. This result should not lead us to the conclusion that there is, in fact, no difference in students' selfratings after attending a blended course. Due to the small number of students who completed the ELP self-assessment in both points of measurement $(n=15)$, it is possible, and even likely, that there was not enough statistical power to detect a difference in scores. This claim is especially valid in the case of a small effect size, that is in case that the teaching has only a small effect on students' self-perceived language competence. Power is additionally jeopardized by having to resort to a non-parametric hypothesis test. Still, using a dependent t-test while the assumptions are violated would have had a detrimental effect on the inferences based on the test's results.

To further test whether students believe that learning in a blended learning environment can raise their awareness of the possibility of more autonomous and independent English language acquisition in relation to traditional classroom learning, their answers to the final two questions of the questionnaire were used. $82 \%$ of them think that learning in an online environment develops learner autonomy. On a scale from 1 to 5, where $1=$ not at all and 5=definitely yes, they expressed their opinion on how important it is for them to set their own pace of learning - they claim it was more important than not $(\mathrm{M}=3.71 / \mathrm{SD}=0.97)$.

However, the question arises: How ready are students to work on their learner autonomy? Based on the data collected, an observation can be made that the students who participated in this study are not yet ready to actively develop their learner autonomy and teacher's assistance is needed (Benson, 2013; Benson \& Voller, 2013; Little, 1991; Nunan, 1991). A possible explanation for coming to such a conclusion is the fact that most of them participated in online tasks to the extent which was required of them in order to only fulfil the minimum requirements to pass the course. On the other hand, some students with their active involvement in particular tasks, demonstrated responsibility for their own language learning. In order for the learner to be perceived as autonomous, they have to be actively involved and aware of their own goals and abilities, which is consequently related to their motivation, confidence, knowledge and skills as interconnected 
components of ability and willingness (Dickinson, 1995; Littlewood, 1997) - ability does not necessarily mean willingness. It could be speculated that some students were not able to perform the required tasks, while some were not willing. If we take into consideration the fact that the majority of students did have the level of knowledge needed to follow the course, it leaves us with willingness that is missing or is not sufficient. As it has been presented earlier in Chapter 3, learners use ICT in their daily lives, but some of them are not as ready to use it for language learning voluntarily (Penner \& Grodek, 2014). In addition, this supports the claims that learners do not use ICT to its full potential or are only focused on doing what needs to be done as part of the course requirements (see Henderson, Selwyn, Neil, \& Aston, 2017; Lai \& Hong, 2014; Thang, et al., 2016; Tri \& Nguyen, 2014; Yunus, Lubis, \& Lin, 2009).

Another explanation could be that learners lacked more general skills such as learning strategies (see Benson 2013) which are needed to achieve autonomy. Since the students are usually not used to a blended learning environment, it could be that they did not possess appropriate learning strategies that would support or enable the development of learner autonomy. The teacher might have a significant role in this situation as a mediator (see Lantolf \& Thorne, 2007; Donato \& McCormick, 1994) and could help direct learners' attention on how to learn, and why, by using technology; that is, to use all the affordances technology brings. With time, the learner could take control over the process and become autonomous and therefore use technologies for language learning in a specific context and choose specific online content that contributes to their language improvement, that is in accordance with a particular language learning purpose (Trinder, 2017).

Providing learners with meaningful tasks, such as wikis or a glossary, allows them to become active in their learning process in which they are able to use their output as a learning resource, which is in accordance with remarks made by Littlejohn (1997). By becoming responsible for their own learning and offering them an option of practicing self-directed learning, learners are led to reach autonomy as a product of such learning (Benson, 2013). The results of this study have shown that part-time students could use this option due to lower presence in classes, and by practicing certain level of individualization they strive toward increasing their own language learning awareness and learning how to be able to recognize and use resources needed to achieve the desired level of skills. 
And the last possibility is that the learning content was not interesting enough or the tasks were not challenging enough for the students. Again, this requires the teacher to be prepared to invest additional time and effort into developing a course which would not only be useful for the learners, but would at the same time be attractive and challenging enough for the learners wanting to learn. And of course, if technology (blended learning) is used, plethora of possibilities exist. This would make the teacher a facilitator, somebody who guides the learner through the process of language learning and towards the 'empowerment' through the new digital environments (Lamy \& Hampel, 2007). For that reason, it would also be equally important to have "check-ins" with the teacher, or short conferences, in order to facilitate a kind of metric against which students can tangibly see how they are progressing, or not progressing. This could possibly drive motivation in a positive direction, and also offer meaningful, descriptive, and relatively immediate feedback that the student could use in an authentic manner.

We wanted to see whether there was a correspondence between students' language competence self-assessment (as measured with the European Language Portfolio) and their performance in a language competence test, used in the pre-test point of measurement, available online and consisting of 15 questions and allowing for immediate feedback. This would provide useful data on how students assess their language competence skills in comparison with objective measurement. The self-assessment composite score was calculated as described earlier in the chapter, first calculating each proportion of checked items for each skill (reading, writing, listening and speaking) and each competence level (A1-C2), then adding up these totals to create a total for each skill, and finally by adding up these totals to create a total composite score, as described in the Methodology chapter.

The strength of the association between students' self-assessments and the teacher's assessment was estimated with Kendall's tau- $a$ coefficient. Kendall's tau- $a$ was used because the teacher's assessment was expressed as a number ranging from 2 to 6 , that is the results were not expressed on an interval scale, which is why Pearson's $r$ could not be used. Field, Miles, \& Field (2012) recommend using Kendall's tau instead of Spearman's rho when there are a lot of tied ranks in the dataset, which is the case here, given that the teacher's assessment had only five possible values. 
Moreover, Field, Miles, \& Field (2012) claim that some research suggests that Kendall's tau could be a better estimate of the correlation in the population than Spearman's rho.

Kendall's tau ranges from -1 to 1 , which represent a perfect negative and perfect positive correlation, respectively. It can be interpreted as the difference between the probability that two objects taken at random from the dataset will be in the same order (e.g. object A is higher than object $\mathrm{B}$ on both the $\mathrm{X}$ and $\mathrm{Y}$ variable) and the probability that they will be in different orders (e.g. object $\mathrm{A}$ is higher than object $\mathrm{B}$ on the $\mathrm{X}$ variable, but object $\mathrm{B}$ is higher than object $\mathrm{A}$ on the $\mathrm{Y}$ variable) (Abdi, 2007; Puka, 2011).

The analysis was conducted using the cor.ci function from the psych package ${ }^{18}$. The estimated coefficient is .38 ( $p<.01,95 \%$ bootstrapped confidence interval $.24-.53)$, indicating that there is a positive relationship between students' self-assessment and the teacher's assessment. This suggests that the students can self-assess their language skills in a way which to a certain extent corresponds to their objectively tested skills.

We decided to assess the association between students' language competence self-assessments on the ELP and vocabulary knowledge, we calculated the Spearman's rho correlation coefficient, using the cor.ci function from the psych package. We decided not to use Pearson's $r$ because there were several outliers - students whose results on one or both assessments were unusually low compared to the rest of the sample. The estimated coefficient is .24 and does not cross the conventional threshold of statistical significance $(p=.07,95 \%$ bootstrapped confidence interval: $.01-.48)$, implying that there is no association between students' language competence selfassessment and their vocabulary knowledge. Hence, we cannot reject the hypothesis of no association between the teacher's test and the students' self-assessments. In other words, there is no evidence of an association between those two measures. Potential explanations are numerous. It could be that those two measures capture totally different aspects of language knowledge. This interpretation would be consistent with the null hypothesis of no association. On the other hand, it

\footnotetext{
${ }^{18}$ https://CRAN.R-project.org/package=psych
} 
is also possible that one or both tests lack the sensitivity or precision required to detect an association.

\subsection{Blended Learning and Students' CMC Competences and Professional Vocabulary Acquisition}

One of the aims was to assess whether students' technological competences are associated with professional vocabulary acquisition in the blended learning condition, which relates to the third hypothesis. In order to do this, the first section of the questionnaire was used in the pre-testing and post-testing stage to calculate $\mathrm{CMC}$ competences which were tested for association between them and professional vocabulary test scores.

First, the results of the first section of the questionnaire referring to the students' perception of their general competence of computer-mediated communication will be presented and then the comparison with vocabulary scores will be made. Then, for each of the items of the questionnaire the joint results will be presented. They will be followed by the results comparing BL group and FtF group in the pre-test phase to see whether any differences exist between these two groups. In the end, the results obtained by FtF group and compared in the pre- and post-test stage. It was expected that using technologies and Moodle or the CMC competence of the FtF group would not change in the post-testing phase due to the fact that it was not required of them to use technology for language learning. On the other hand, the competence of the BL group was expected to be different in the pre- and post-stage testing. For that reason, the comparison between these two groups was made only in the pre-test stage. This enabled confirming homogeneity of the groups with regard to CMC competence and technology usage.

The participants were asked to indicate their answer to the questions using a 5-point Likert Scale with a range of answer options where $1=$ not at all and $5=$ very much. The questions were related to their motivation to use $\mathrm{CMC}$ in interaction with others, their knowledge of $\mathrm{CMC}$, efficacy and efficiency/productivity and general usage/experience. All the answers were analysed and mean values for each of the questions were calculated. Mean values 1-3.50 have been treated as low, while 3.51-5 have been treated as high. The values were analysed using the statistical computing language R (R Core Team, 2017). 
The first two questions - Do you enjoy communicating using computer media? and Are you motivated to use computers to communicate with others? - were related to motivation. The answers given by the students across both groups indicate that they enjoy using computer media $(\mathrm{M}=4.317 / \mathrm{SD}=0.808)$ and are motivated when using computers when communicating with others $(\mathrm{M}=4.388 / \mathrm{SD}=0.767)$. Both of the mean values express high motivation.

The same is true if we compare the answers to these questions between the FtF and the BL group - their answers are similar and mean values are very close (for the $\mathrm{FtF}$ group $\mathrm{M}=4.302 / \mathrm{SD}=0.798$ and $\mathrm{M}=4.393 / \mathrm{SD}=0.787$ for each question respectively and for the $\mathrm{BL}$ group $\mathrm{M}=4.237 / \mathrm{SD}=0.783$ and $\mathrm{M}=4.367 / \mathrm{SD}=0.771$ for each question respectively). This is visible in Figure 10.

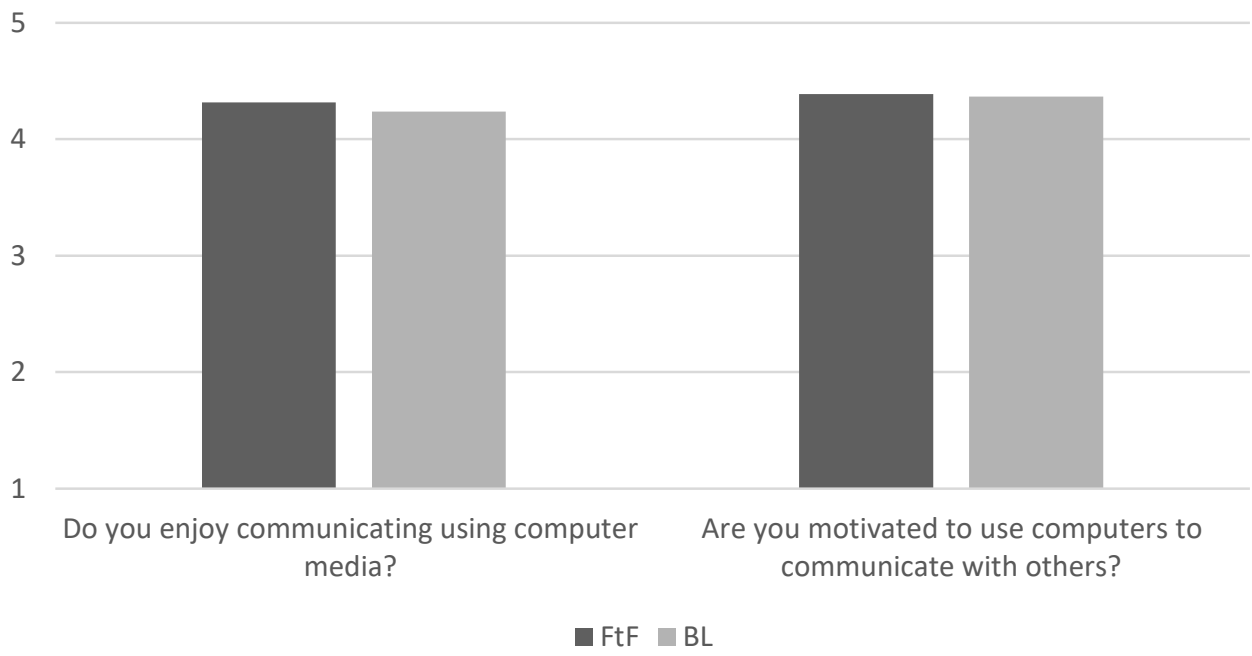

Figure 10. General motivation using computers - FtF group compared to BL group

When comparing pre- and post-test results of the BL group, the outcomes are quite similar when it comes to the average values (pre-test $\mathrm{M}=4.237 / \mathrm{SD}=0.783$ and post-test $\mathrm{M}=4.051 / \mathrm{SD}=1.005$ for the first question and $\mathrm{M}=4.367 / \mathrm{SD}=0.771$ and post-test $\mathrm{M}=4.22 / \mathrm{SD}=0.966$ ). However, their 
motivation in the final testing stage is slightly lower than at the beginning of the semester (Figure 11). This will be commented on in Discussion, Chapter 7.

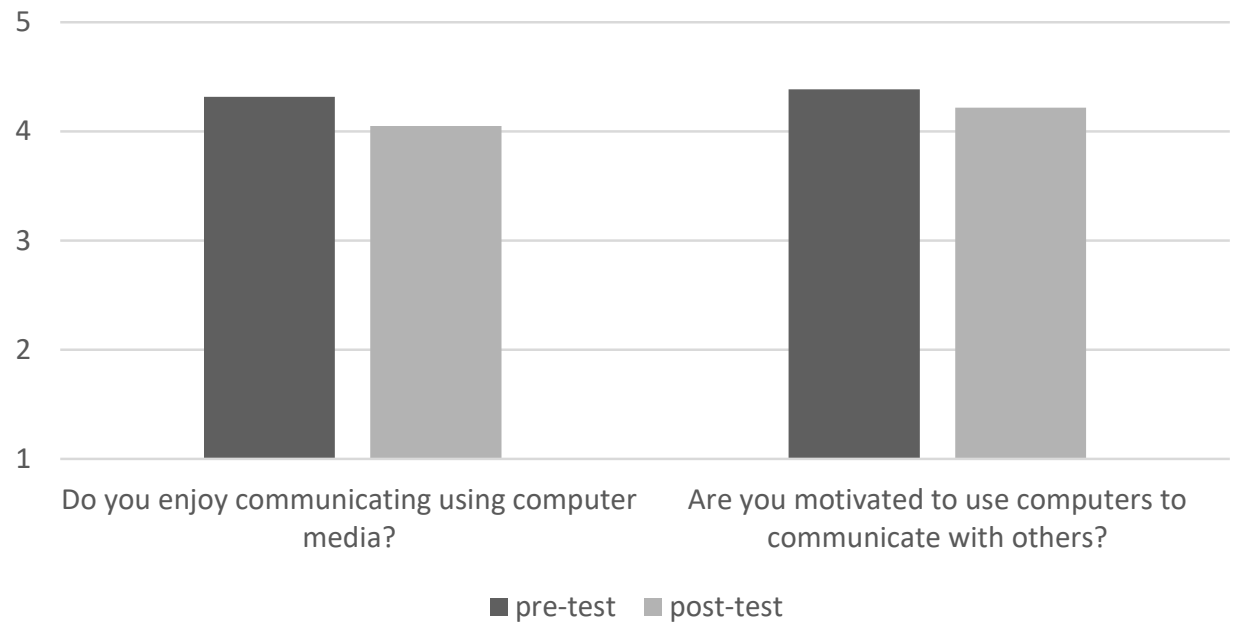

Figure 11. General motivation using computers - BL group in the pre-and post-test stages

The following two questions - Are you knowledgeable about how to communicate through computers? and When communicating with someone through a computer, do you know how to adapt your messages to the medium? - indicated students' perception of their knowledge of using computers. The mean value for the results of the first question across both groups ( $M=4.822 /$ $\mathrm{SD}=0.412$ ) shows that the students believe they know how to communicate through computers. When it comes to adapting messages through the medium, they are also quite confident $(\mathrm{M}=4.503 / \mathrm{SD}=0.639)$. This points to the students being comfortable with regard to their CMC knowledge and use.

When the responses from the FtF group and the BL group are compared and analysed, they correspond to the answers across both groups (for the $\mathrm{FtF}$ group $\mathrm{M}=4.853 / \mathrm{SD}=0.497$ and $\mathrm{M}=4.597 / \mathrm{SD}=0.681$ for each question respectively and for the $\mathrm{BL}$ group $\mathrm{M}=4.9 / \mathrm{SD}=0.302$ and $\mathrm{M}=4.582 / \mathrm{SD}=0.612$ for each question respectively). This is visible in Figure 12. 


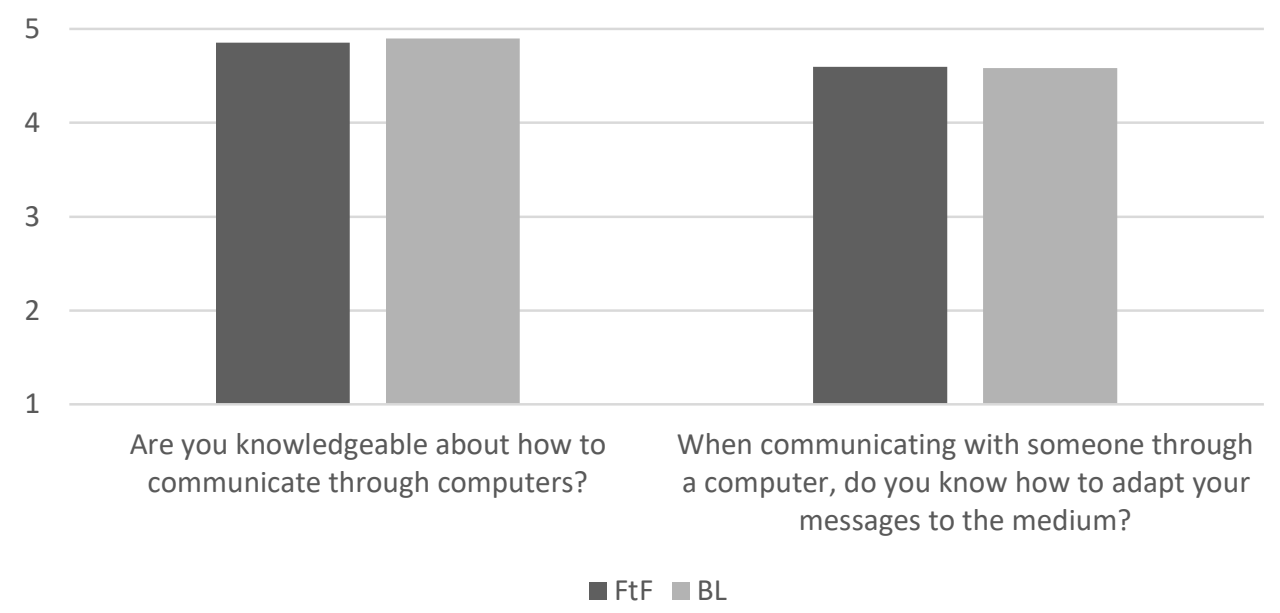

Figure 12. General knowledge of using computers - FtF group compared to BL group

When comparing pre- and post-test results of the BL group, the answers are quite similar when it comes to the average values (pre-test $\mathrm{M}=4.9 / \mathrm{SD}=0.302$ and post-test $\mathrm{M}=4.763 / \mathrm{SD}=0.567$ for the first question and $\mathrm{M}=4.582 / \mathrm{SD}=0.612$ and post-test $\mathrm{M}=4.712 / \mathrm{SD}=0.559)$ and this is visible in Figure 13. The mean values of the answers regarding adapting messages to the medium is slightly higher.

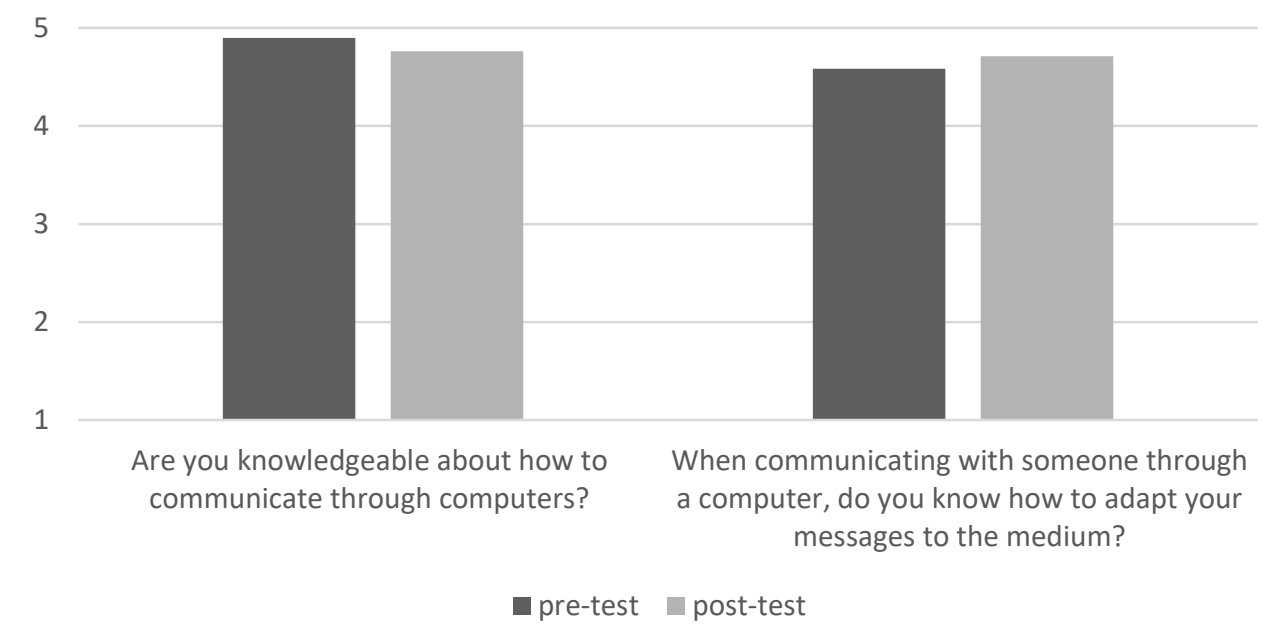

Figure 13. General knowledge of using computers - BL group in the pre-and post-test stages 
Based on the answers that the students gave to the following question (Do you find changes in technologies frustrating?), the mean value for both groups was calculated $(\mathrm{M}=2.689 / \mathrm{SD}=1.243)$. It indicates that students do not feel greatly intimidated by the fast changes in technology. Being a generation of digital natives, they quickly adapt to these changes.

If the $\mathrm{FtF}$ group is compared to the $\mathrm{BL}$ group, the mean values are again almost identical $(\mathrm{M}=2.698 / \mathrm{SD}=1,279$ and $\mathrm{M}=2.638 / \mathrm{SD}=1.314)$. As can be seen in Figure 14, their level of intimidation by technology is almost the same.

5

4

3

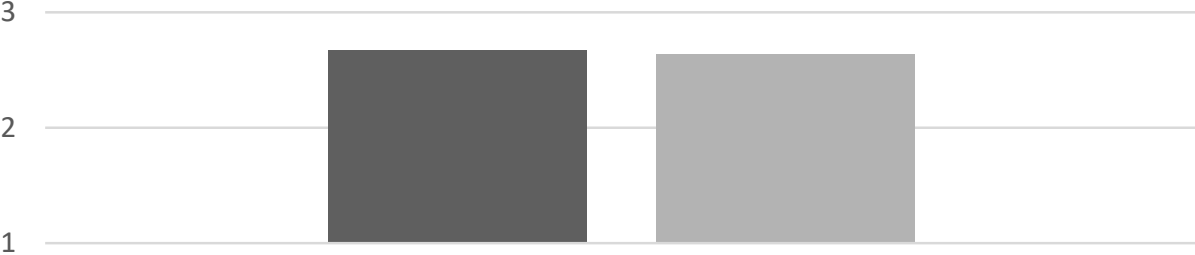

Do you find changes in technologies frustrating?

$\square \mathrm{FtF} \quad \mathrm{BL}$

Figure 14. The level of frustration with changes in technology - FtF group compared to BL group

When comparing pre- and post-test results of the BL group, the responses that indicate the low level of frustration with changes in technology and are quite similar when it comes to their average values (pre-test $\mathrm{M}=2.638 / \mathrm{SD}=1.314$ and post-test $\mathrm{M}=2.695 / \mathrm{SD}=1.38$ ) and can be seen in Figure 15. 


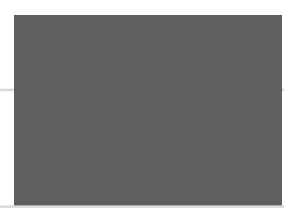

Do you find changes in technologies frustrating?

a pre-test post-test

Figure 15. The level of frustration with changes in technology-BL group in the pre-and posttest stages

Efficiency and productivity were investigated with three questions (Are you more efficient using CMC than other forms of communication (e.g. letters)? Are you more efficient using CMC than face-to-face interaction? Are CMC technologies time-savers for your work?). The mean values of the students' answers were calculated $(\mathrm{M}=4.111 / \mathrm{SD}=0.945 ; \quad \mathrm{M}=3.257 / \mathrm{SD}=1.066$; $\mathrm{M}=4.017 / \mathrm{SD}=0.902$ respectively). Therefore, the students perceive themselves as quite efficient when using $\mathrm{CMC}$, but they are less positive and feel less efficient when asked to compare using $\mathrm{CMC}$ with face-to-face interaction. Nevertheless, they feel CMC technologies help them save time while working.

If the groups are considered separately, the difference with regard to these three questions is again minor (for the $\mathrm{FtF}$ group $\mathrm{M}=4.129 / \mathrm{SD}=0.938 ; \mathrm{M}=3.298 / \mathrm{SD}=1.058 ; \mathrm{M}=4.068 / \mathrm{SD}=0.904$ for each question respectively; and for the $\mathrm{BL}$ group $\mathrm{M}=4.138 / \mathrm{SD}=0.924 ; \mathrm{M}=3.329 / \mathrm{SD}=1.022$; $\mathrm{M}=4.125 / \mathrm{SD}=0.906$ for each question respectively) and are visible in Figure 16. 
5
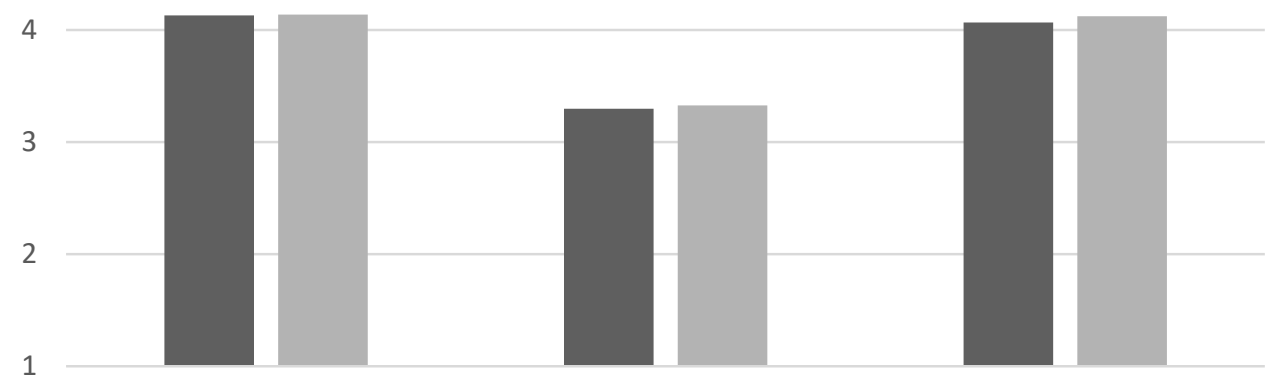

Are you more efficient using

$\mathrm{CMC}$ than other forms of

Are you more efficient using

Are CMC technologies time-

communication (e.g. letters)

CMC than face-to-face

savers for your work?

interaction

- FtF $\square \mathrm{BL}$

Figure 16. Efficiency and productivity - FtF group compared to BL group

When comparing the pre- and post-test stage results of the BL group, the average values that indicate the students' efficiency and productivity when using CMC are again very similar (for the pre-test stage $\mathrm{M}=4.138 / \mathrm{SD}=0.924 ; \mathrm{M}=3.329 / \mathrm{SD}=1.022 ; \mathrm{M}=4.125 / \mathrm{SD}=0.906$ for each question respectively; and for the post-test stage $\mathrm{M}=4.193 / \mathrm{SD}=0.833 ; \mathrm{M}=3.259 / \mathrm{SD}=1.052$; $\mathrm{M}=4.293 / \mathrm{SD}=0.879$ respectively) and point to no statistically significant change between the two stages (Figure 17). 


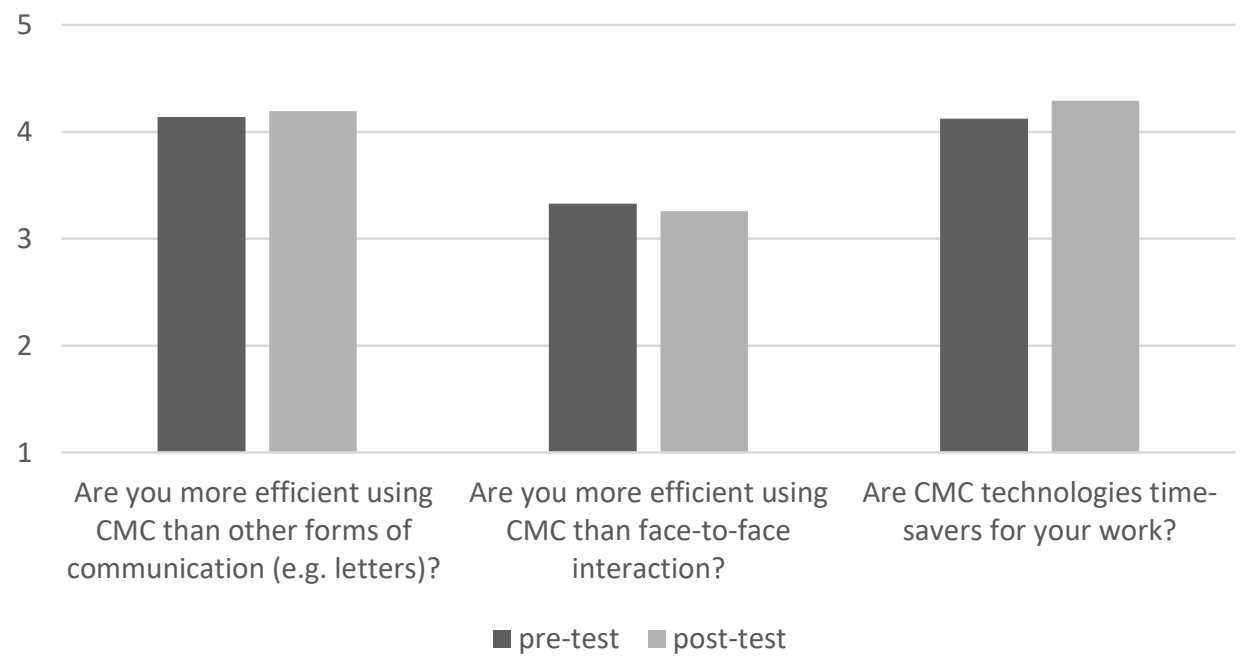

Figure 17. Efficiency and productivity - BL group in the pre-and post-test stages

Another question - Do you rely upon CMC for getting you through each day? - was used to refer to the general usage of CMC throughout the day. Upon calculating mean values of the answers to the question $(M=3.656 / \mathrm{SD}=0.935)$ across both groups, the results show that the students rely on $\mathrm{CMC}$, and show a very slight inclination towards a positive perception but not as much as expected.

When the results of the groups are compared per group $(\mathrm{M}=3.669 / \mathrm{SD}=0.998$ for the $\mathrm{FtF}$ group and $\mathrm{M}=3.737 / \mathrm{SD}=0.896$ for the $\mathrm{BL}$ group), it is obvious that they are again almost identical (Figure 18). 
5

4

3
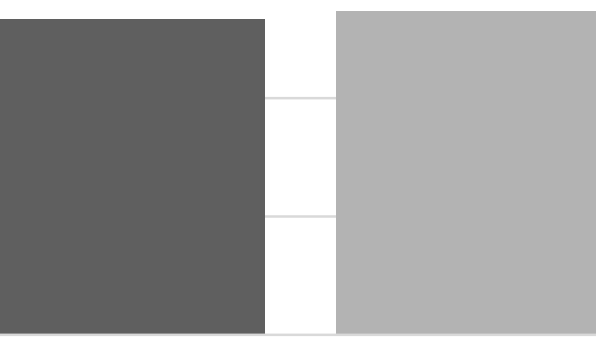

Do you rely upon $\mathrm{CMC}$ for getting you through each day?

$\square \mathrm{FtF} \square \mathrm{BL}$

Figure 18. General usage and reliance on CMC - FtF group compared to BL group

When comparing pre- and post-test results of the BL group, the answers that give information on general usage and reliance are almost identical with regard to the average values (pre-test $\mathrm{M}=3.737 / \mathrm{SD}=0.896$ and post-test $\mathrm{M}=3.759 / \mathrm{SD}=1.048$ ) and can be seen in Figure 19.

5

4

3

2

1

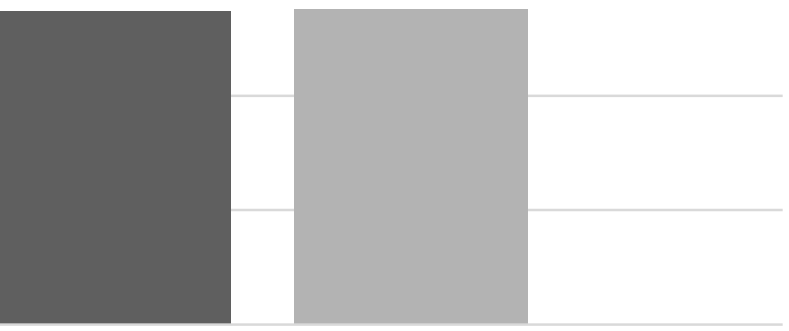

Do you rely upon $\mathrm{CMC}$ for getting you through each day?

a pre-test $\quad$ post-test

Figure 19. General usage and reliance on CMC-BL group in the pre- and post-test stages 
In order to learn successfully in a blended learning environment, it is relevant to have a minimum level of technological skills to follow the course and concentrate on other aspects that relate to student learning. This is not an issue for the generation of students who use technology on a daily basis. Nevertheless, the participants in the study were asked to self-assess their general CMC competence. Based on their answers, it can be seen that the levels of motivation to use CMC to communicate are shown to be quite high for both groups and for both stages of the BL group - the results across the groups are very similar. The only minor difference that can be noticed is a minor decrease in motivation between the pre- and the post-test stage for the BL group. Therefore, the results of this study confirm Spitzberg's $(2006 ; 2011)$ presumptions that there is no increase in motivation when using CMC.

The students assess their CMC knowledge as very high (with mean values of more than 4.8\%) and are quite confident when using it. The results do not show any statistically significant differences, but a small increase can be noticed in the self-assessment values in the post-test stage related to the knowledge on how to adapt messages to the medium.

According to the results, even though changes in technology happen almost on a daily basis, they do not perceive it as a problem and most of them do not find these changes frustrating. As mentioned before, this does not come as a surprise.

The students consider themselves to be quite efficient when using CMC in comparison with other forms of communication. However, when the results are compared in the pre- and the post-test stage in relation to $\mathrm{CMC}$ being compared to face-to-face interaction, its perceived level of efficiency shows a slight decline in the post-test stage. It could be presumed that the students believe that face-to-face interaction can be more efficient than using a CMC tool in many situations. Nevertheless, they think that CMC technologies help them save time while working and perceive them as a reliable means to get through the day.

To assess the students' CMC competences, an ad hoc, nine-item, Likert-type scale was used. It consisted of the nine questions which are contained in the first part of the questionnaire. These questions are taken as the measure of their general CMC competence since they refer to motivation, 
knowledge, efficacy, efficiency/productivity and general usage/experience. Its reliability, assessed as Cronbach's $\alpha$ is .71. In order to determine if there is an association between the BL group's technological competences and their post-test professional vocabulary scores, we fitted a linear regression model, controlling for the students' pre-test scores. The pre-test scores and technological competence scores were entered in a single step.

The overall model shows a statistically significant improvement over the null model $\left(R^{2}=.43\right.$, $F(2,44)=16.93, p<.01)$, that is the model which contains no independent variables, and predicts the group mean as each individual's vocabulary score. However, the CMC competence scores are not a significant predictor of post-test scores $(\beta=0.08, p=.58)$. The model's predictivity lies solely in the pre-test scores $(\beta=0.6, p<.01)$. This tells us that there is no evidence that students with higher technical competence scores achieve higher post-test professional vocabulary scores than students with lower technical competence scores, or vice versa. To put it succinctly, there is no evidence of any kind of association between technical competencies and professional vocabulary scores at the end of the semester. Further, as expected, a significant effect of baseline professional vocabulary was found, implying that higher baseline professional vocabulary scores are associated with higher professional vocabulary scores after learning.

Table 2. Summary of the multiple regression model with CMC competence as a predictor of post-test professional vocabulary scores, controlling for pre-test professional vocabulary scores $\left(R^{2}=.43, F(2,44)=16.93, p<.01\right)$

\begin{tabular}{lrrrr} 
Coefficient & $\beta$ & $\mathrm{SE}$ & $\mathrm{t}$ & $\mathrm{p}$ \\
Prof. vocab. pre-test** & 0.6 & .11 & 5.6 & $<.01$ \\
Tech. comp. & 0.08 & 0.14 & 0.56 & .58 \\
\hline
\end{tabular}

$* * \mathrm{p}<.01$ 
The participants were also asked about the CMC tools they used. Their responses indicated that some of the tools were used more frequently than others, and with a different level of comfort. As well as indicating the frequency of using a particular CMC tool (e-mail, chat, IM, SMS, social networking, forum, wiki, MMO (Massively multiplayer online) games, weblog), the students had to state how comfortable they feel when using the tool by indicating the level of frequency and comfort on a scale where $1=$ not at all and $5=$ very much. The results (Figure 20) show that the most frequently used $\mathrm{CMC}$ tool by comparing mean values of the obtained results is chat $(\mathrm{M}=4.291 / \mathrm{SD}=1.078)$ followed closely by SMS $(\mathrm{M}=4.208 / \mathrm{SD}=0.874)$. The least used $\mathrm{CMC}$ tool is blog $(\mathrm{M}=1.938 / \mathrm{SD}=1.126)$. With regard to the feeling of comfort, respondents feel most comfortable using those tools that they frequently use, that is, chat $(\mathrm{M}=4.263 / \mathrm{SD}=1.019)$ and SMS $(\mathrm{M}=4.253 / \mathrm{SD}=0.862)$. They seem to be less comfortable with the tools used in the context of this study (that is, forums, wikis and blogs) - which they also use less frequently.

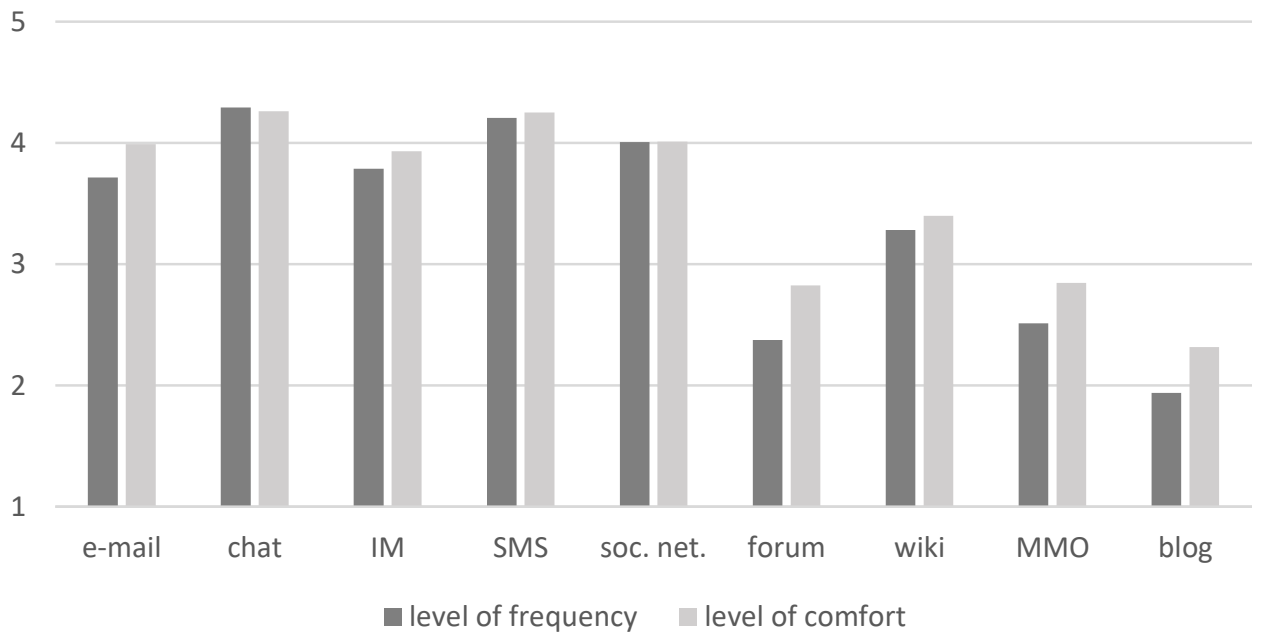

Figure 20. The comparison of how frequently students use CMC tools and how comfortable they feel while using them 
In order to see whether there was any difference between the results of the FtF group and the BL group student answers were analysed separately and then compared. When it came to the first question regarding frequency of usage of CMC tools, the results were slightly different from the results obtained across both groups. The first two most frequently used $\mathrm{CMC}$ tools used by the FtF group were chat $(\mathrm{M}=4.203 / \mathrm{SD}=1.023)$ and $\mathrm{SMS}(\mathrm{M}=4.192 / \mathrm{SD}=0.803)$, followed by social networks $(\mathrm{M}=4.017 / \mathrm{SD}=1.131)$. As for the $\mathrm{BL}$ group, with chat being most popular $(\mathrm{M}=4.31 / \mathrm{SD}=1.096)$ and social networks in second place $(\mathrm{M}=4.119 / \mathrm{SD}=1.131)$, they are followed by $\mathrm{SMS}(\mathrm{M}=3.915 / \mathrm{SD}=1.022)$ and e-mail $(\mathrm{M}=3.915 / \mathrm{SD}=1.039)$, exhibiting exactly the same mean value. The frequency of these and other tools when compared between the two groups is presented in Figure 21.

5

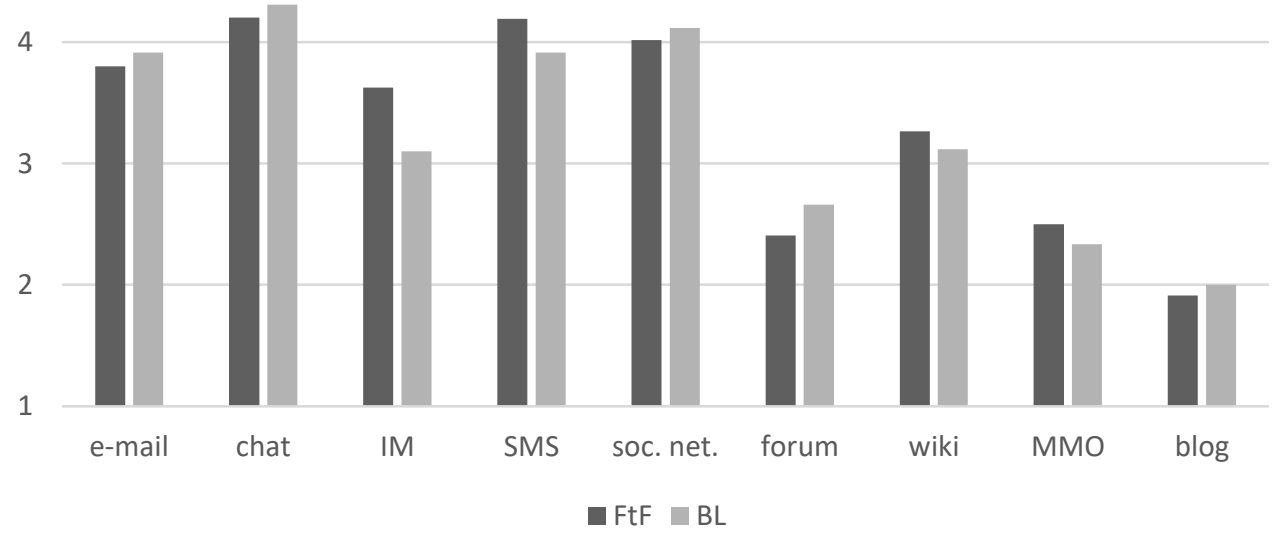

Figure 21. The comparison of how frequently students use CMC tools - FtF group compared to BL group

As it regards the second question on how comfortable the students feel when using CMC, by analysing their answers and comparing the FtF group and the BL group, the results show that they feel most comfortable using SMS (for FtF group $\mathrm{M}=4.249 / \mathrm{SD}=0.893$ and for the BL group 
$\mathrm{M}=4.266 / \mathrm{SD}=0.902$ ) and chat (for $\mathrm{FtF}$ group $\mathrm{M}=4.201 / \mathrm{SD}=1.003$ and for $\mathrm{BL}$ group $\mathrm{M}=4.165 / \mathrm{SD}=1.006)$. In Figure 22 it can be seen that the values are approximately the same.

5

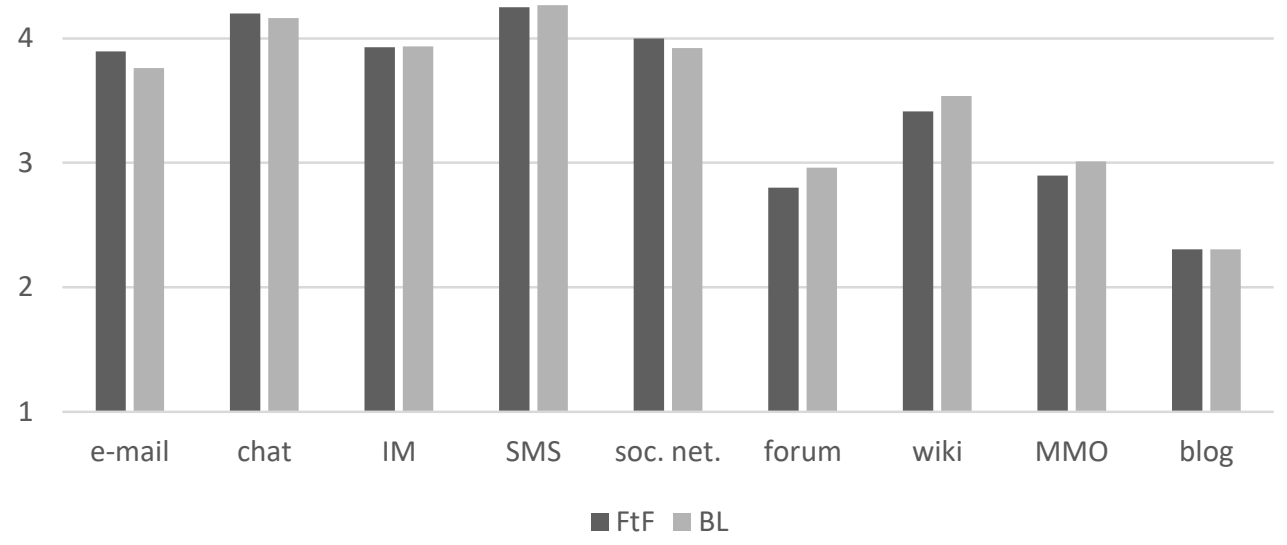

Figure 22. The comparison of how comfortable students feel when using CMC tools - FtF group compared to BL group

The same analysis was conducted for the BL group with regard to the frequency and comfort of the use of CMC tools in the pre- and post-test stage. In this analysis, the main data of interest is the slightly greater use of wikis in the post-test stage (from $\mathrm{M}=3.119 / \mathrm{SD}=1.219$ to $\mathrm{M}=3.487 / \mathrm{SD}=1.09$ ) while the remaining data mainly corresponds to expected results based on previous comparisons as can be seen in Figure 23. 


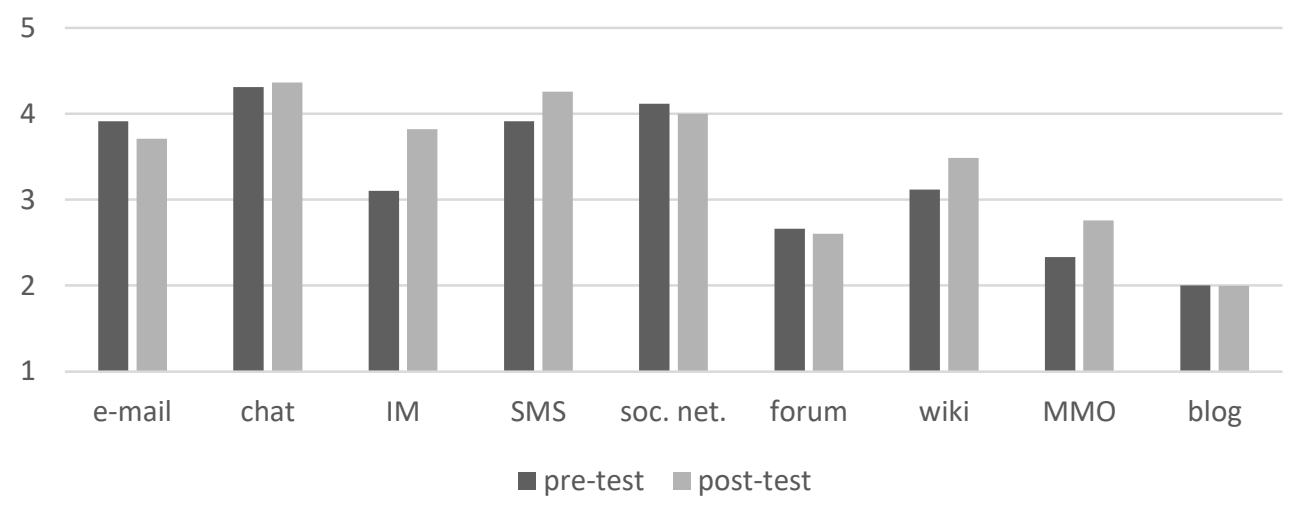

Figure 23. The comparison of how frequently students use CMC tools - BL group in the pre-and post-test stages

As it regards the second question on how comfortable they feel when using CMC tools in the preand post-stage of the results of the BL group, the results show a smaller decrease in mean values from the pre-test to the post-test stage in every aspect but e-mail (from $\mathrm{M}=3.763 / \mathrm{SD}=1.046$ to $\mathrm{M}=3.983 / \mathrm{SD}=0.938$ ), forum (from $\mathrm{M}=2.962 / \mathrm{SD}=1.481$ to $\mathrm{M}=3.288 / \mathrm{SD}=1.327$ ) and blog (from $\mathrm{M}=2.304 / \mathrm{SD}=1.362$ to $\mathrm{M}=2.649 / 1.506$ ). Blog has not been used as a $\mathrm{CMC}$ tool for language learning during the research while forum has been used by the teacher only, which will be discussed later in Chapter 7. The comfort using other tools can be seen in Figure 24. As for wikis, the level of comfort is slightly lower in the post-test stage (from $\mathrm{M}=3.538 / \mathrm{SD}=1.245$ to $\mathrm{M}=3.356 / \mathrm{SD}=1.27$ ). 
5

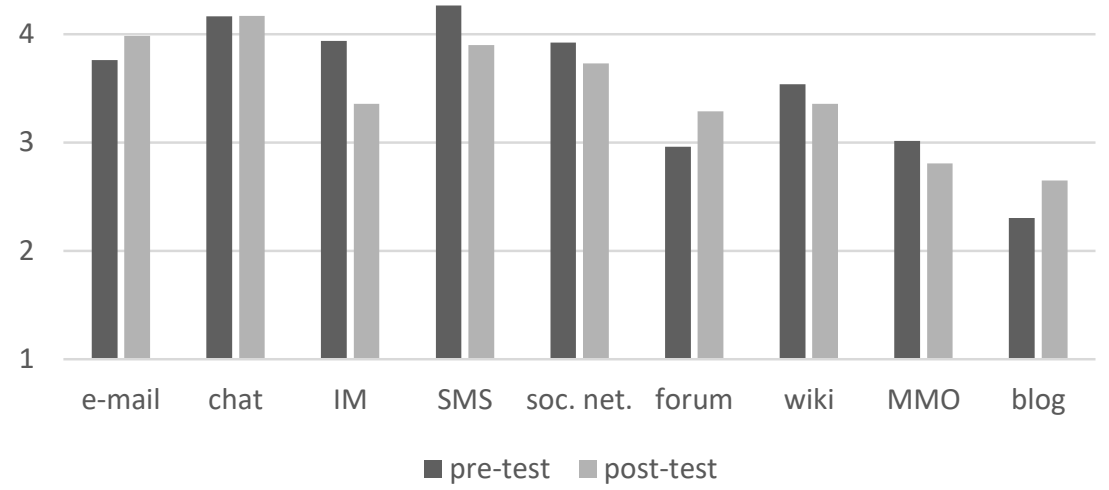

Figure 24. The comparison of how comfortable students feel when using CMC tools - BL group in the pre-and post-test stages

When asked about the CMC tools they use, their answers show more frequent usage of some tools than others and a different level of comfort. They most frequently communicate via chat and SMS. This is in correlation with the level of comfort. The results obtained based on these answers were in accordance with recent trends since these tools are available in one place - on a smartphone (Fibaek Bertel \& Ling, 2014; Vorderer, Krömer, \& Schneider, 2016). When comparing the results of pre- and post-testing for the BL group, information that is somewhat surprising is that the frequency of use and the level of comfort regarding the use of wikis did not increase significantly (from $M=3.119$ to $M=3.487$ ) - they both remained relatively low, under the value of 3.5. This means that the use of wikis as part of student tasks during the semester did not change their behaviour or opinion. One of the reasons might be that they had to work on two wikis only and according to the data, not many of them actually added information more than once; most of them completed the task by inserting what had to be inserted and considered the task done. Prior to the research, the students were told that in order to pass the course, they needed to perform at a minimum level only by adding one item. Some of the students understood the task quite literally. 
The questions about general CMC competence were followed by questions related to technology and experience in its use for academic purposes. Only those results that were different in the preand post-test stages will be mentioned and later discussed. This section of the questionnaire referred to technology and academic experience. The students were required to mark which device they use for academic purposes, how often and how important they think it was by indicating the answers on a 5-point Likert Scale. The results show that the students use all the devices (PC, laptop, tablet, smartphone) for academic purposes, but with different degrees of frequency and levels of considered importance, which are presented in Figure 25. The most frequently used device for academic purposes is a laptop and the least used is a tablet, which corresponds to their attitude regarding the importance of the devices for academic purposes.

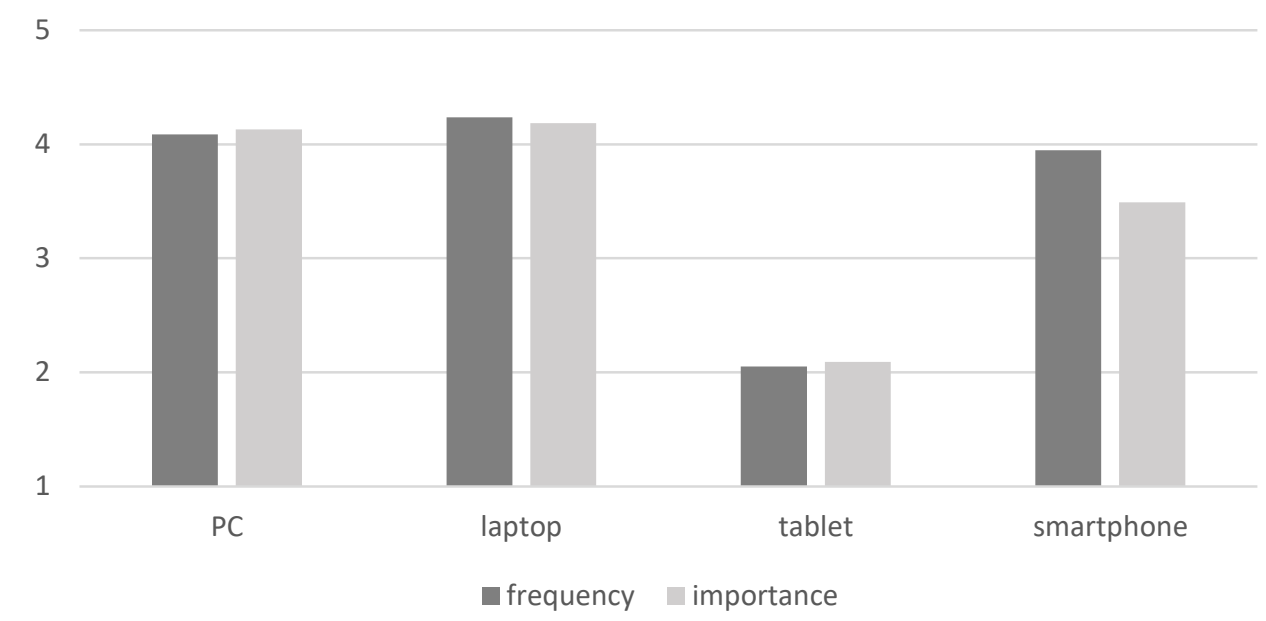

Figure 25. The frequency and importance of using electronic devices for academic purposes

Next, their level of agreement with the statement on a scale 1 to 5 (where $1=$ I disagree completely and 5= I agree completely) was analysed in a question which considers their perception of how important it is for the teacher to use new technologies. The obtained results suggest that they consider it quite important $(\mathrm{M}=3.904 / \mathrm{SD}=0.943)$. 
When asked what kind of a course the students think they would benefit most from (with no online components, with some online components, or completely online) by rating their answers on a scale from 1 to 5, their answers were mostly in favour of a course with some online components $(\mathrm{M}=3.576 / \mathrm{SD}=0.954)$. It is interesting that the average values have shifted from the point of view of the BL group in the period of pre- and post-testing, with fewer students preferring a course without any online components and more students thinking that they would benefit most from a completely online course (see Figure 26).

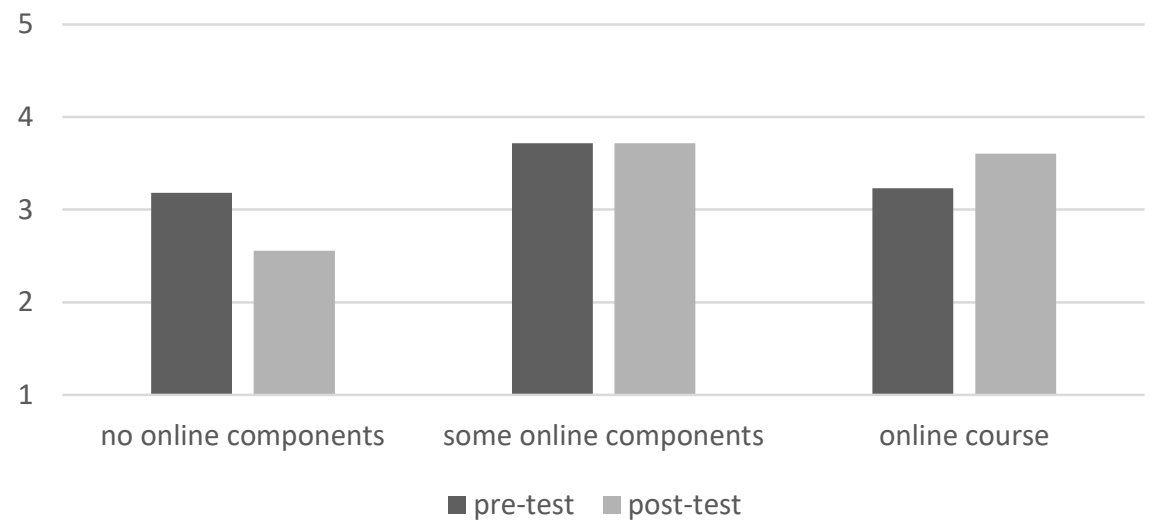

Figure 26. Benefits from courses organized with or without (some) online components (BL group)

The students confirm having some experience with blended and online courses in the previous semester: on average four courses $(\mathrm{M}=3.711 / \mathrm{SD}=2.662)$ in a blended learning environment and one course $(\mathrm{M}=1.071 / \mathrm{SD}=1.669)$ completely online. This might suggest that the English language course in blended learning environment had some impact on their change of opinion.

The following question was in the form of a table and it required students to do two things: to indicate (tick) those forms of communication they find useful for learning English, that is, e-mail, SMS, chat, Twitter, Facebook, LinkedIn, direct communication over the Internet (Skype), phone conversation, face-to-face interaction, LMS (Moodle), or other; and then they were asked for which 
other purpose they use that particular tool - whether to communicate with peers, their teacher, acquaintances or for distance learning.

For the first part of the question they could tick more than one tool. The number of times a particular tool was marked was taken as the number that would show which form of communication they thought was useful for learning English. The results across both groups show that they find Moodle to be the most useful form of communication for learning English - Moodle was ticked the highest number of times $(\mathrm{N}=29)$. It is followed by communication by e-mail and face-to-face form of communication. This is visible in Figure 27.

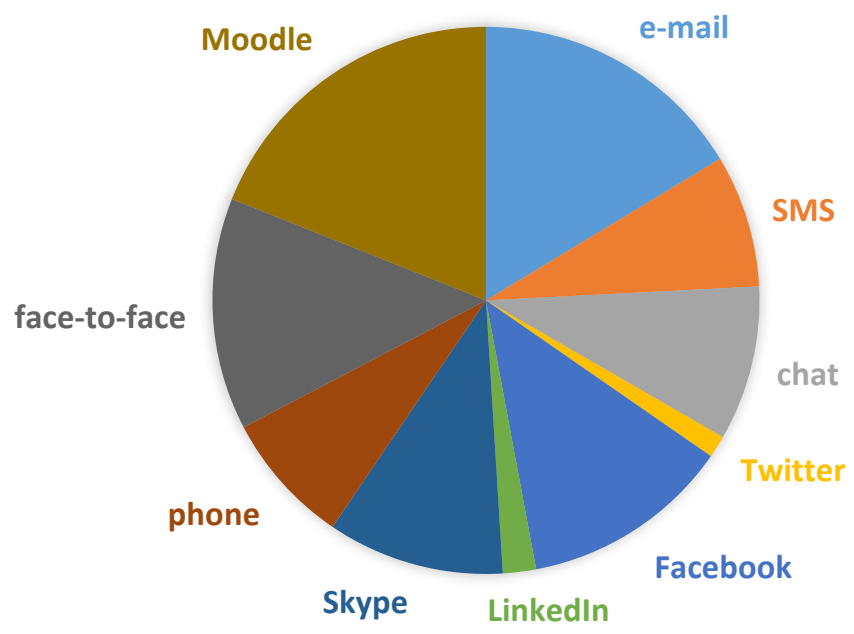

Figure 27. The usefulness of a particular form of communication for learning

When comparing the results of the FtF group with the BL group in the pre-test stage, but also in the post-test stage for the BL group, the results show almost identical proportions. However, in the post-test stage chat was marked the same number of times as face-to-face communication $(\mathrm{N}=8)$ and thus shares the third place (Figure 28). 


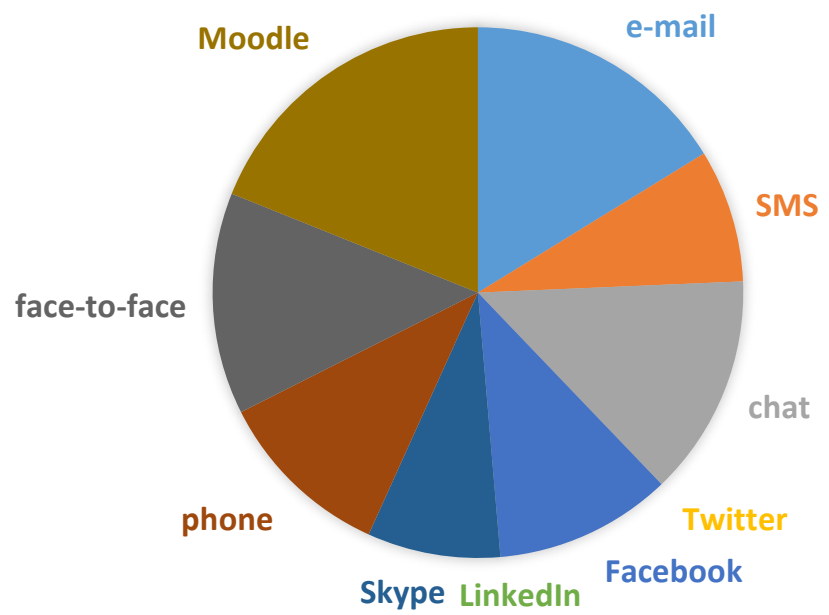

Figure 28. The usefulness of a particular form of communication for learning English - BL group in the post-test stage

The second part of the question asked about the most useful form of communication with peers, teachers, acquaintances and for distance learning. The results across both groups (Figure 29) indicate that the most useful form of communication with teachers, according to the students, is email; when it comes to communication with their peers and acquaintances, it is Facebook; and, they consider Moodle to be the most useful form of communication for learning in an online environment. Since Moodle is used as the learning platform where all the tasks are performed, this is a useful piece of information for the teacher. 


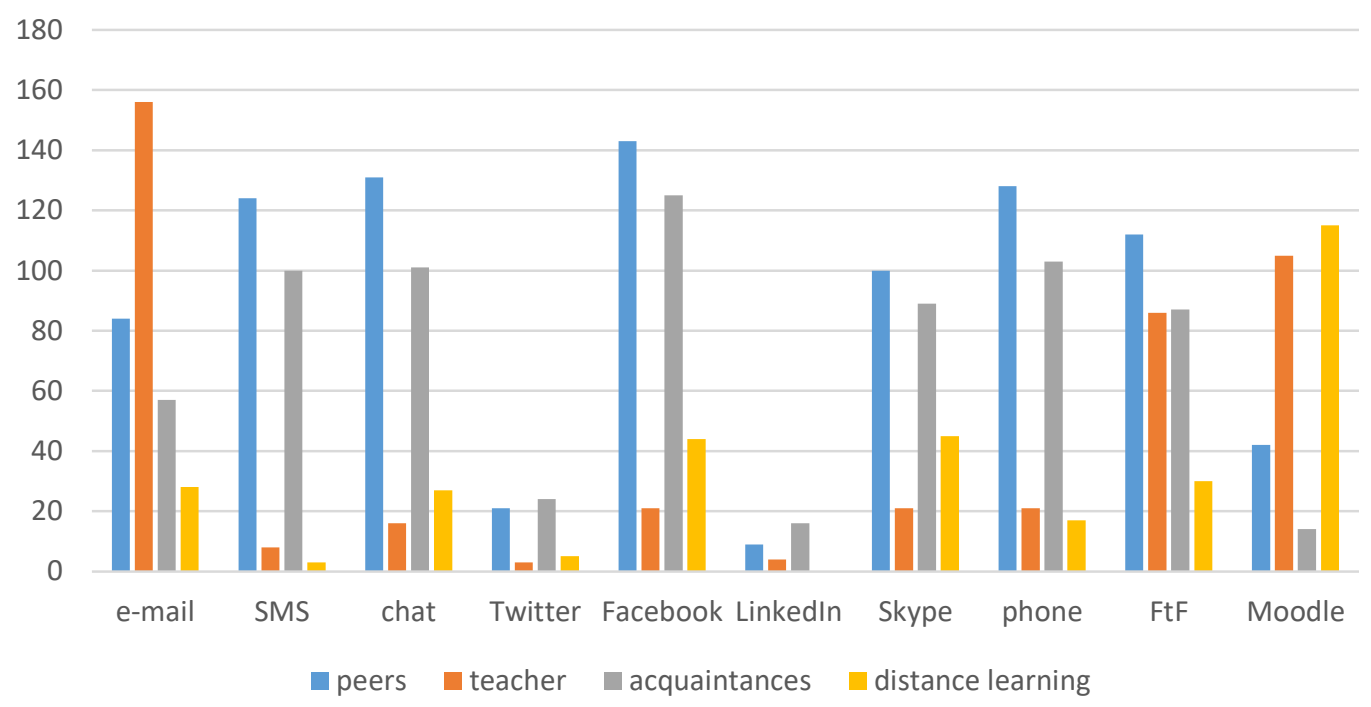

Figure 29. Students' perception of useful forms of communication for different purposes

If the results are analysed by comparing the $\mathrm{FtF}$ group and the $\mathrm{BL}$ group for each of the categories separately, we get the following results which are visible in Figures 29a-29d. It can be seen that the favourite form of communication with peers for both groups is Facebook, but for the FtF group it is followed by chat and SMS, while for the BL group Facebook is followed by phone and then chat (Figure 29a). 


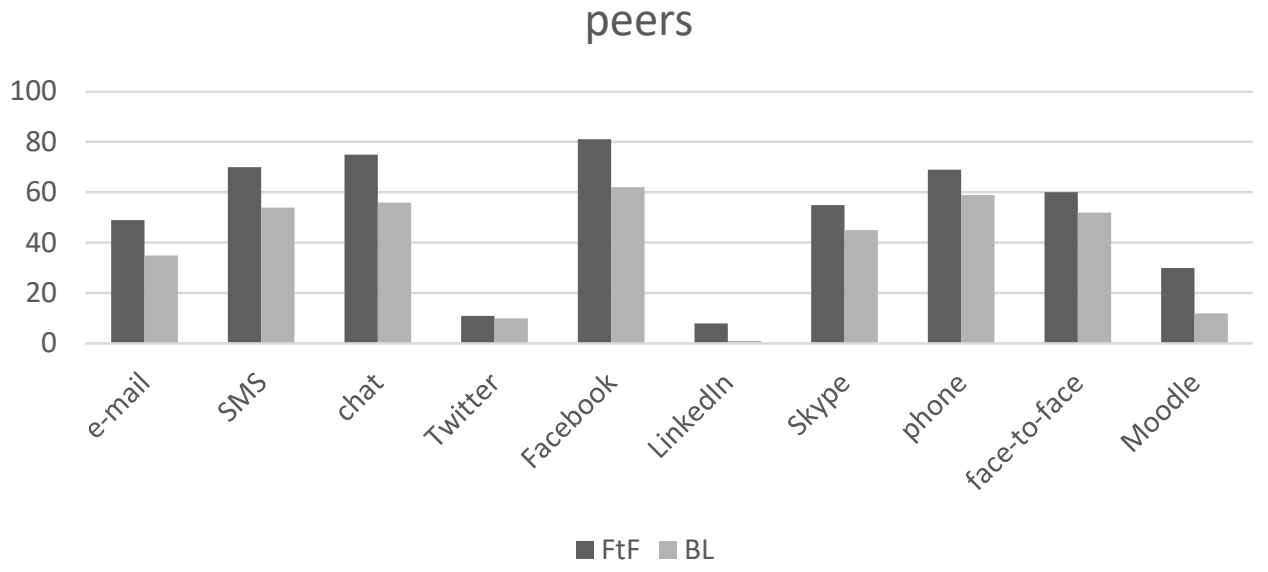

Figure 29a. Form of communication with peers - FtF group compared to BL group

Regarding the form of communication that the students would use with the teacher, the results are the same: e-mail followed by Moodle and then face-to-face communication (Figure 29b).

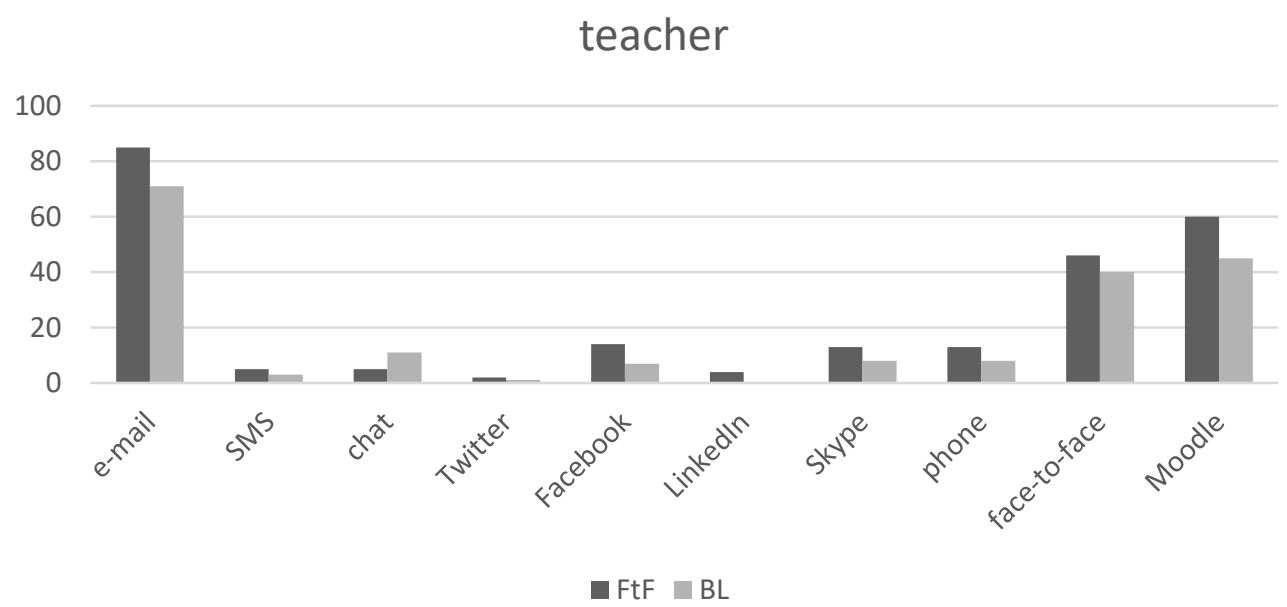

Figure 29b. Form of communication with the teacher - FtF group compared to BL group 
When acquaintances are the focus, the preferred form of communication is again Facebook, but other forms are also frequently used (Figure 29c). For the FtF group Facebook is followed by SMS, chat and phone, which share the number of times they were chosen by the students ( $\mathrm{N}=58)$. With the BL group, Facebook is followed by phone and chat.

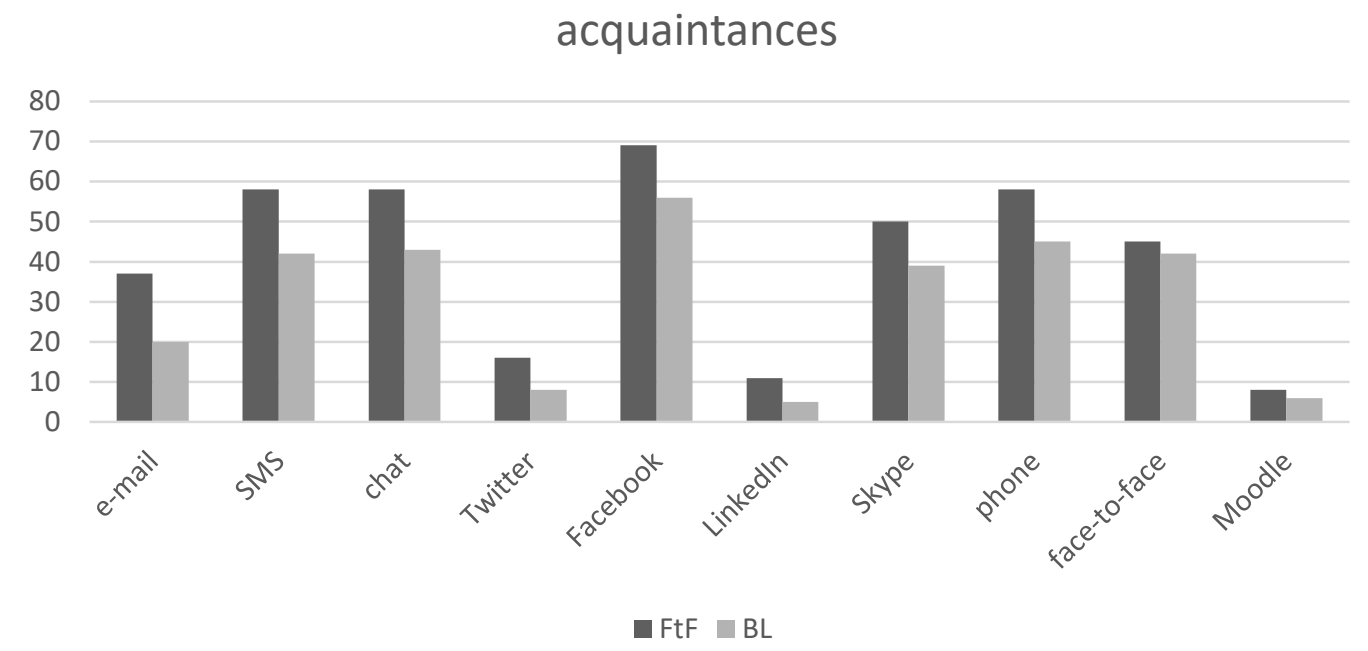

Figure 29c. Form of communication with the teacher - FtF group compared to BL group

With distance learning the situation is quite clear: Moodle is the form of communication they would choose for distance learning (Figure 29d). 


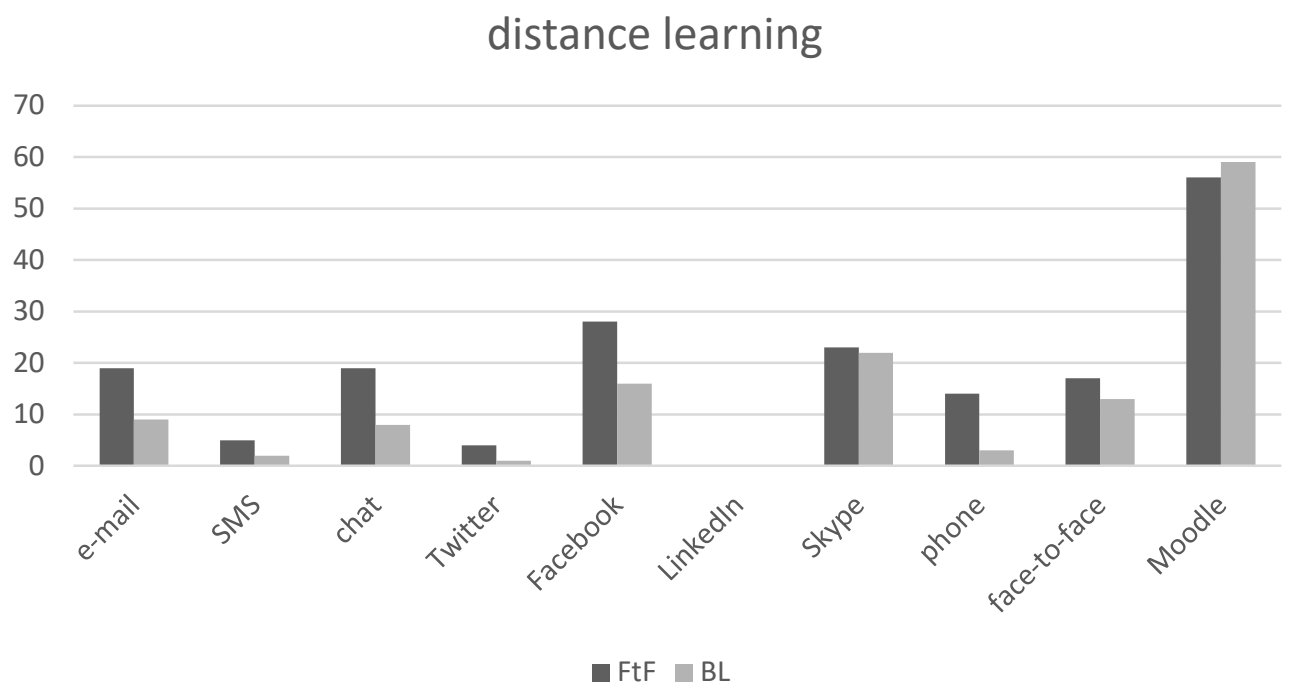

Figure 29d. Form of communication for distance learning - FtF group compared to BL group

The results of the pre-test and post-test stage of the BL group with regard to the form of communication they would use to communicate with their peers, teacher, acquaintances and for distance education have been compared and are evidenced in Figures 30a-30d. When communicating with peers, not much is different from the previous results: Facebook remains the form of communication they would use most (Figure 30a). In both stages of testing it is followed by phone and chat. 


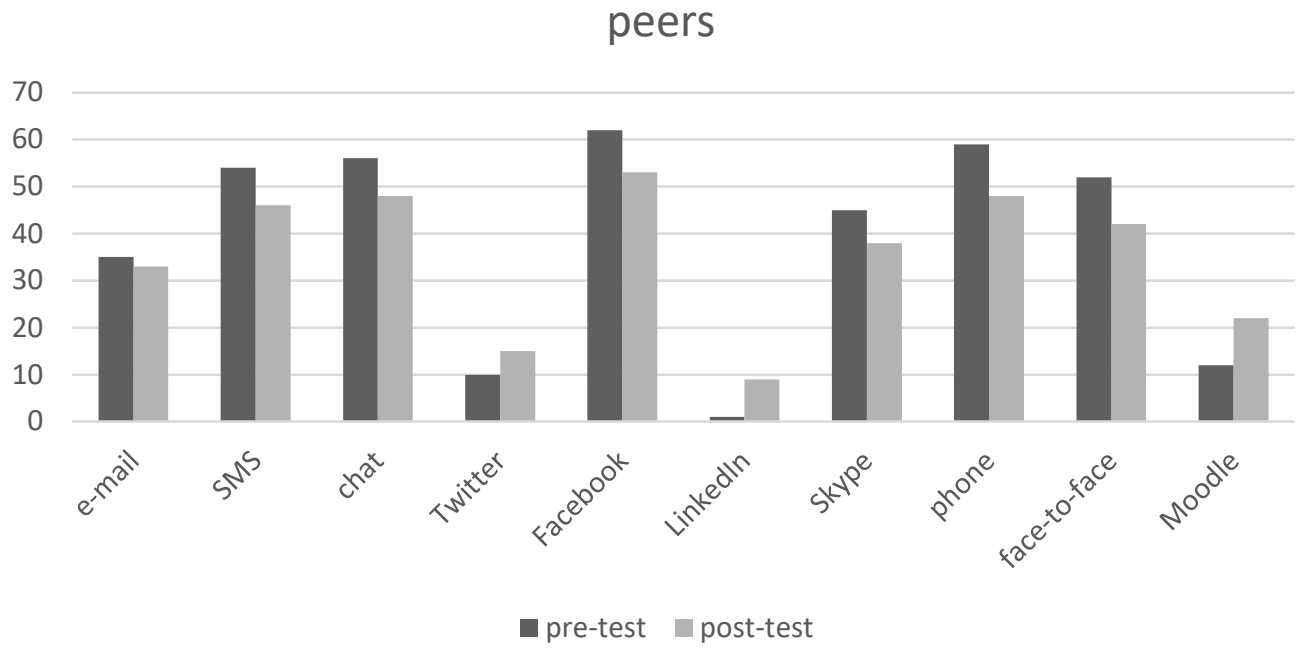

Figure 30a. Form of communication with peers - BL group in the pre-and post-test stages

When it comes to communication with their teacher, students in the BL group would prefer using e-mail in both stages of testing. In the pre-test stage e-mail is followed by Moodle and face-to-face. However, the choice of face-to-face communication with the teacher gained more support when compared to Moodle in the post-test stage (Figure 30b). 


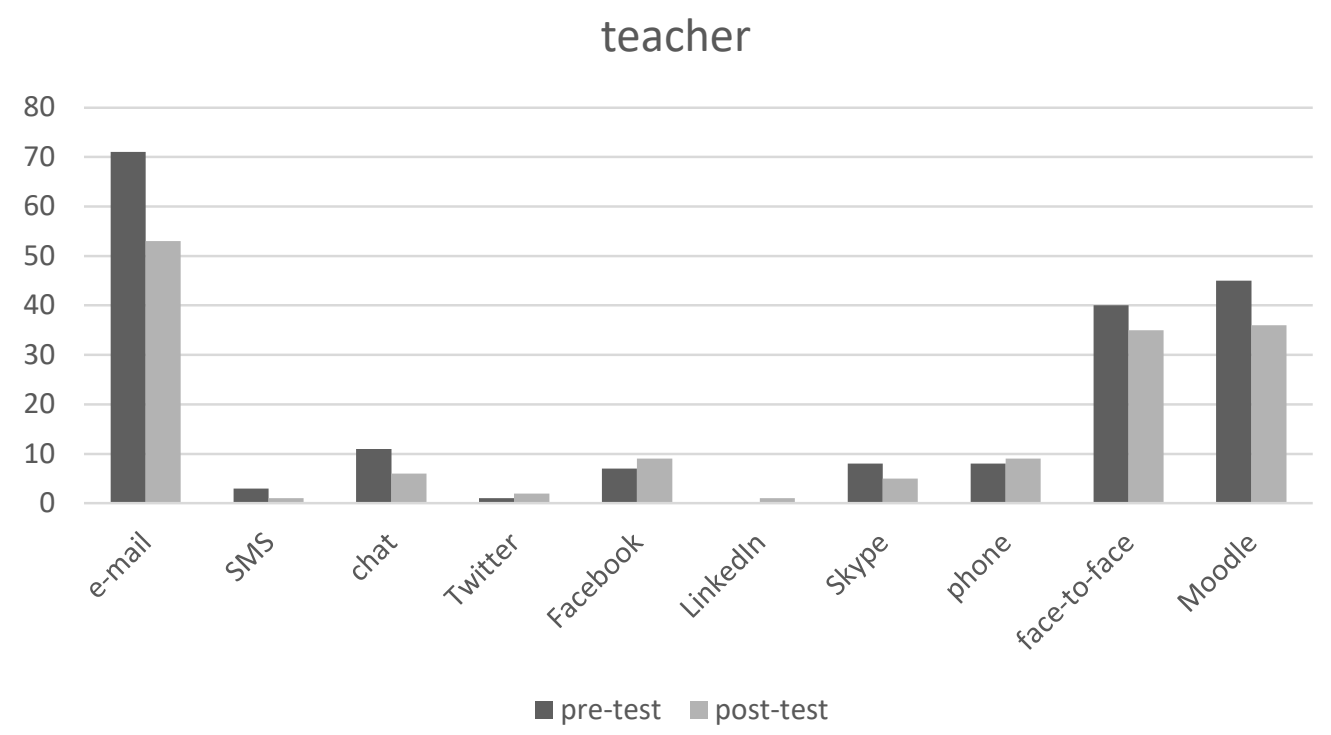

Figure 30b. Form of communication with the teacher-BL group in the pre-and post-test stages

Facebook is again chosen as the form of communication with acquaintances and other forms are chosen in a similar manner (Figure 30c).

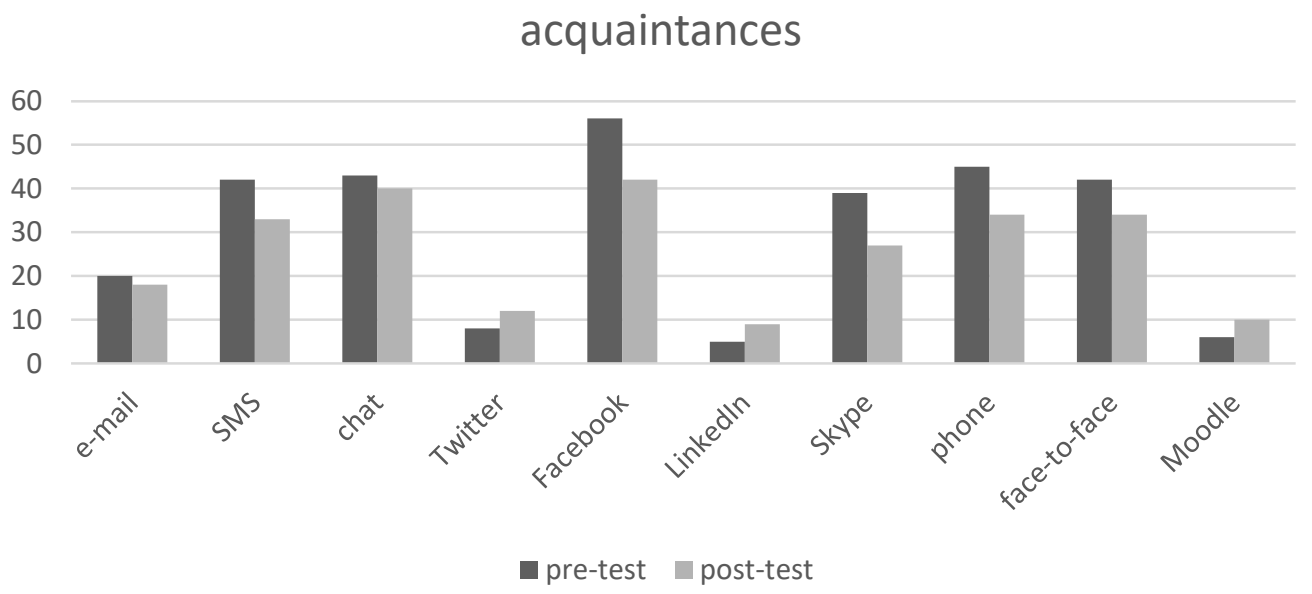

Figure 30c. Form of communication with acquaintances - BL group in the pre-and post-test stages 
Again, the preferred method of communication for distance learning would be Moodle in both stages of testing (Figure 30d).

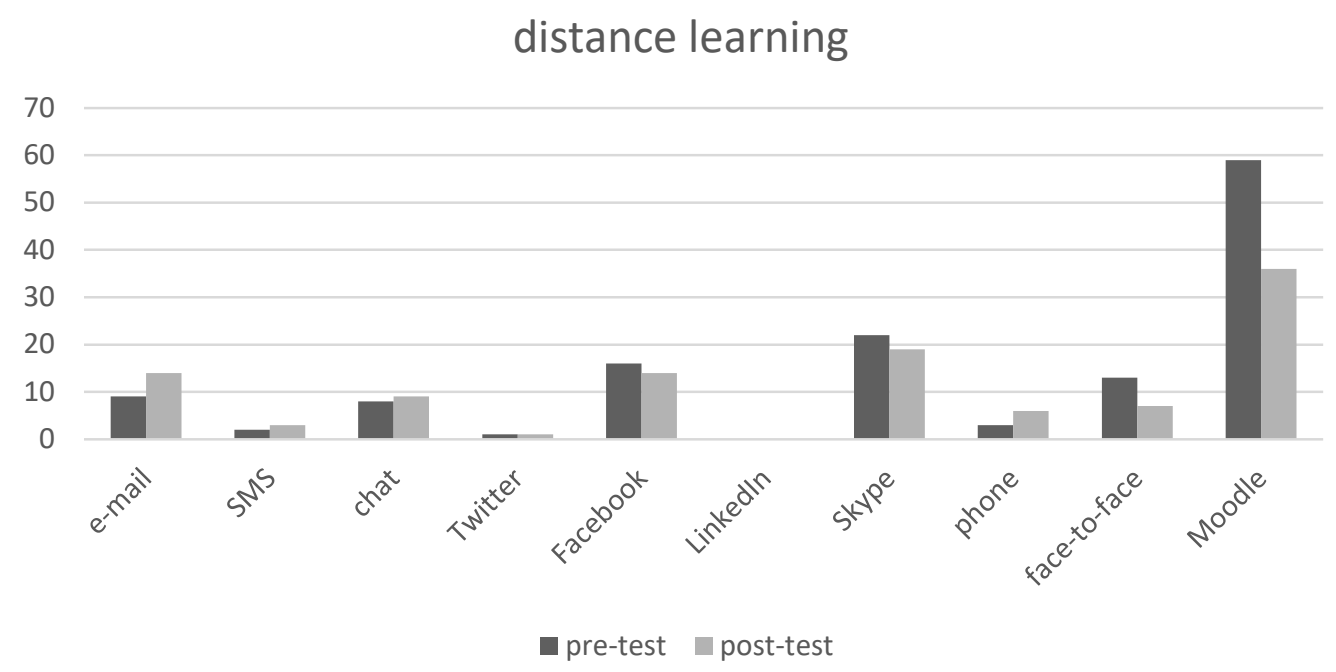

Figure 30d. Form of communication used for distance learning - BL group in the pre-and posttest stages

Closely related to the results described here are the students' responses to the following two questions about Facebook: whether they consider Facebook useful when it comes to communication and interaction with their peers or teachers about coursework (not necessarily about language learning) outside the classroom, not as part of a task set by the teacher. The possible answers were 'yes' or 'no'. The results show that $92.1 \%$ of the students consider it useful to interact with their peers, while the only $46.6 \%$ consider it useful to communicate with their teachers. The results, when compared between the FtF and the BL groups as well as those in the pre- and posttest stage of the BL group are almost identical and differ in a very small percentage. In addition, this is in accordance with the results presented in earlier paragraphs.

The next question was whether students consider forums to be a useful method of communication and interaction with peers and teachers outside the classroom. As answers to the question show, 
forums are perceived as useful for communication with peers outside the classroom by $80.1 \%$ of students. Again, the results are almost identical across the groups when comparing them separately.

The questions that followed had the purpose of finding out about students' active involvement and learning when using technology in the process of learning English. The students were asked to indicate their answers on a 5-point scale, where $1=$ not at all and 5=definitely yes. However, using more technology would not have a significant impact on their active involvement $(\mathrm{M}=3.469 / \mathrm{SD}=1.103)$. They generally do not have a habit of skipping classes when the lesson materials are published online $(\mathrm{M}=2.19 / \mathrm{SD}=1.29)$. However, when looking at the pre- and posttesting for the BL learning group, the result changes in favour of skipping classes $(\mathrm{M}=3.06 / \mathrm{SD}=1.43)$. They are more inclined towards technology in the function of preparing them for future educational plans $(\mathrm{M}=3.870 / \mathrm{SD}=0.994)$. They strongly believe that technology helps them in their field of work $(\mathrm{M}=4.227 / \mathrm{SD}=0.943)$ and that it elevates the level of teaching. The results show that the students have a positive attitude towards using technology in the English language classroom.

Participant replies related to technology used for academic purposes and the general overall experience when using particular technology yielded insight into participants' preferences. Even though students use all devices (PCs, laptops, tablets and smartphones) for academic purposes, laptops are used the most and tablets, the least. This correlates with student attitude regarding the importance of a computer device for academic purposes and in accordance with other research conducted (e.g. Barber, DiGiuseppe, van Oostveen, Blayone, \& Koroluk, 2016; Brooks \& Pomerantz, 2017).

Students' awareness of the importance of using technology for academic purposes can be seen in the results which show that for them, it is quite important that the teachers use new technologies. Since this digital generation of students is immersed in technology, it is of no surprise that they expect the same of their teachers. Their belief that technology enhances the level of teaching should be used by teachers as a support to introduce it into language learning. 
Students had already had some experience learning in a blended learning environment in the semester before this study was conducted. They perceive value of online components in learning. Based on the results of the BL group, whose opinion had more weight in the post-testing phase and was worth investigating since they experienced blended learning approach in language learning for the purposes of the study, their perception of how much they can learn through the course with online components has increased while it has decreased for the courses with no online components. This suggests that the students learning in a blended learning environment recognize the value of learning using online components and are positively inclined towards using them. This is in accordance with the research already mentioned in the literature review and therefore contributes to the field of using a blended learning environment for language learning (Bañados, 2006; BuenoAlastuey \& López Pérez, 2014; Oliver 2005; Rahman, Hussein, \& Aluwi, 2015; Spanjers, et al., 2015; Şahin-K1z1l, 2014; Woltering, Herrler, Spitzer, \& Spreckelsen, 2009). This relates to the importance of interaction and the context - interaction using CMC tools (in this case a computer and an LMS) leads to a different perception of the context in which the learning is accomplished.

This is consistent with one of the key findings of a large study of undergraduate students and information technology, involving $130 \mathrm{US}$ and international institutions and more than 64,000 students. "While a plurality (38\%) of students prefer fully face-to-face classroom environments, students who have taken some fully online courses are significantly more likely to prefer blended environments and less likely to prefer purely face-to-face courses." (Galanek, Gierdowski \& Brooks, 2018, p. 5)

When learning English, the results show that students prefer the e-mail method to communicate with teachers. This complements the research literature where the importance and benefits of email in learner-teacher communication is emphasized (Beatty, 2010; Bloch, 2002; Hassini, 2006), showing that email continues to be the most common communication tool at a tertiary institution. When students communicate with their peers or acquaintances, on the other hand, they prefer Facebook. This outcome was expected considering the fact that this social networking site prevails as the most frequently used form of communication among young people, whether for the sake of socializing and belonging (Cheung, Chiu, \& Lee, 2011) or for political engagement (Vromen, 
Xenos, \& Loader, 2015). When it comes to distance learning Moodle (as an example of a LMS) is the preferred tool of students, and they see it as the tool which dominates others in this field.

Even though many students do not regard Facebook as a good platform through which to communicate about English coursework, or to communicate with teachers, it is up to the teacher whether to use their students' willingness to communicate with their peers in such a way as to turn this platform into a place for collaboration. In addition, the literature has shown that using social networks can positively impact learning (Irwin, Ball, \& Desbrow, 2012; Lambić, 2016).

On the other hand, forums, which have been shown to be a very useful CMC tool for collaboration and learning (Fabbri, 2018; Ochoa Alpala, 2014) and are perceived as useful for communication with peers outside the classroom by the majority of students, were not used at all by the students during the research. The learners had been instructed to communicate using the forum in case any problem occurred or if they just wanted to discuss a task with their peers. This lack of use is not necessarily surprising - even though they are aware that a forum can be useful for communicating with peers they are not accustomed to doing so.

The results that followed show that even though the students have positive attitudes towards using technology, it does not have a significant impact in the context of their English language classes. Thus, just using technology does not immediately make the course more attractive. Having materials available online would not be an incentive to skip classes. As has been recorded in the results, there is a difference in the pre- and post-testing phase for the BL group - the students tend to stay at home when materials from the course are available online. The reason for that might lie in their realization that by learning in a blended environment they can follow the course without having to be present in face-to-face classes. They consider technology useful in their field of work and for preparing them for the future educational plans.

The study has shown that students are highly motivated when using computers for the purpose of communication, and that they feel they are very adept and competent in this. They are quite confident regarding their CMC knowledge even when it comes to rapid changes in technology. Students perceive themselves as quite efficient when using CMC and regard their production 
positively. They feel most comfortable when chatting, which at the same time makes chat a frequently used communication tool. When communicating for academic purposes, they use laptops most frequently as they are considered to be more important than other devices (e.g. a tablet). By being members of the digital generation, the students felt that teachers should also be familiar with the most recent technologies, which they consider to be of great importance.

To sum up, students are willing to use technology and the various forms of communication that it offers for educational purposes and perceive it as an asset to learning and communication with their teachers and peers. They prefer communicating with teachers by e-mails and with their peers via Facebook. They find Moodle useful for communicating during distance learning, which also confirms their ability to use particular communication tools for particular situations and with particular groups of people. Overall, the results of this study confirm the value of using technology in an English language course and are aligned with much of the research presented in peer reviewed literature (Chun, Kern, \& Smith, 2016; Fučkan Držić, 2009; Liu, Moore, Graham, \& Lee, 2002; Salaberry, 2001).

The focus of the nine questions that followed in the questionnaire was the use of Moodle as the learning management system that is used at the University. The first question they were asked related to their assessment of their knowledge and skills with regard to the use of Moodle, on a scale from 1 to 5, where 1=very low and 5=very high. Their average score was 4.156, which suggests that they are quite satisfied with their knowledge and skills needed for Moodle. According to their responses, they use Moodle mostly several days a week. They were asked to choose one or more purposes that they use Moodle for (Figure 31) - to gather information on the course (e.g. teacher's office hours or exam dates), to download course materials, to participate in forums, to upload homework, to do tests, to create wikis, to communicate with the teacher, to communicate with peers, and to do surveys. Upon analysing the results, they mostly use it to gather information on the course, download materials and upload homework. 


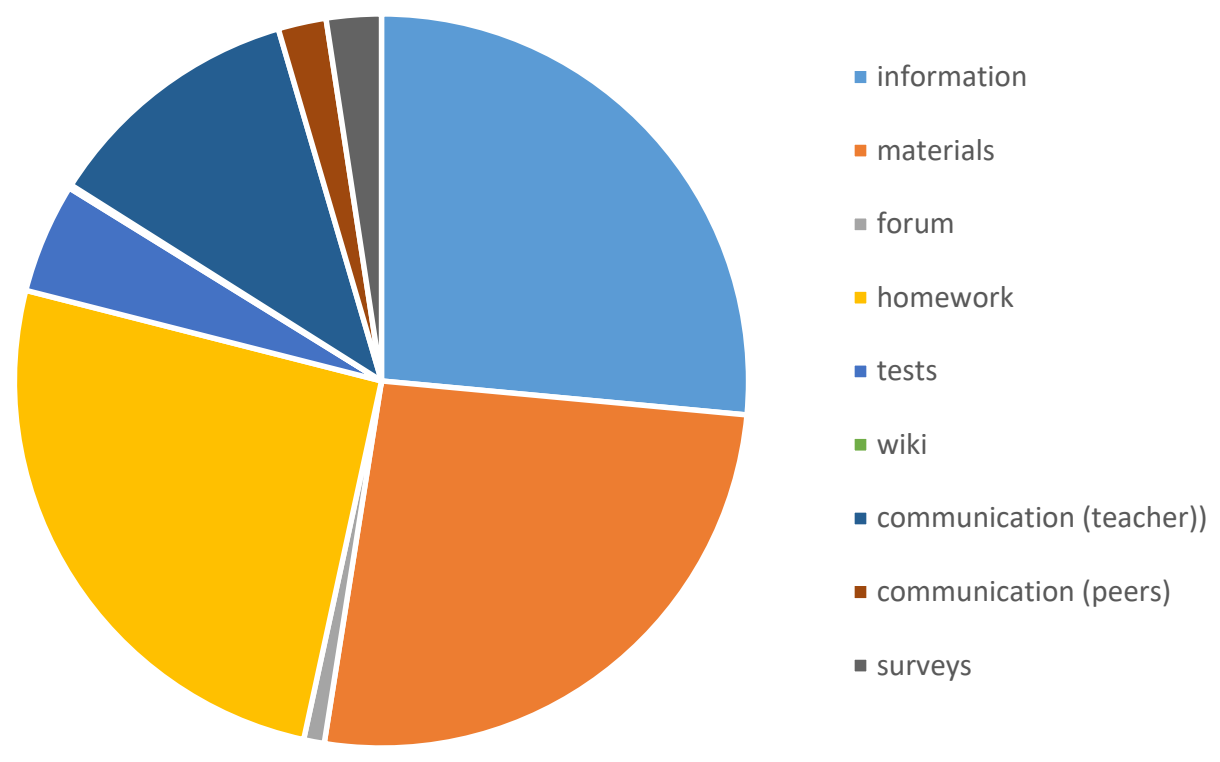

Figure 31. The purpose of using Moodle

Despite having used Moodle for an entire semester, when comparing the results of the BL group at the beginning and at the end of the semester, the only significant difference regarding the use of Moodle was the use of one of its tools - wikis. The results showed an increase in their usage, with $49.12 \%$ of BL students reporting that they used wikis.

The questions that followed provided insight into the students' general attitude towards using Moodle. They could answer the questions with 'yes' or 'no', which allowed extraction of the percentage of students who like using it (89.3\%), who find it useful (96.6\%), who think it increases their productivity (83\%), who think it is easy to use $(92.7 \%)$, and who think it makes learning interesting (59.9\%). When asked if they would be ready to use Moodle several times a week for English lessons, $80.2 \%$ of them confirmed that they would. When the data was compared at the end of semester for the BL group, all the values were slightly higher than in the pre-test stage, except for how much students enjoyed it and with relation to increasing students' productivity (Figure 32). 


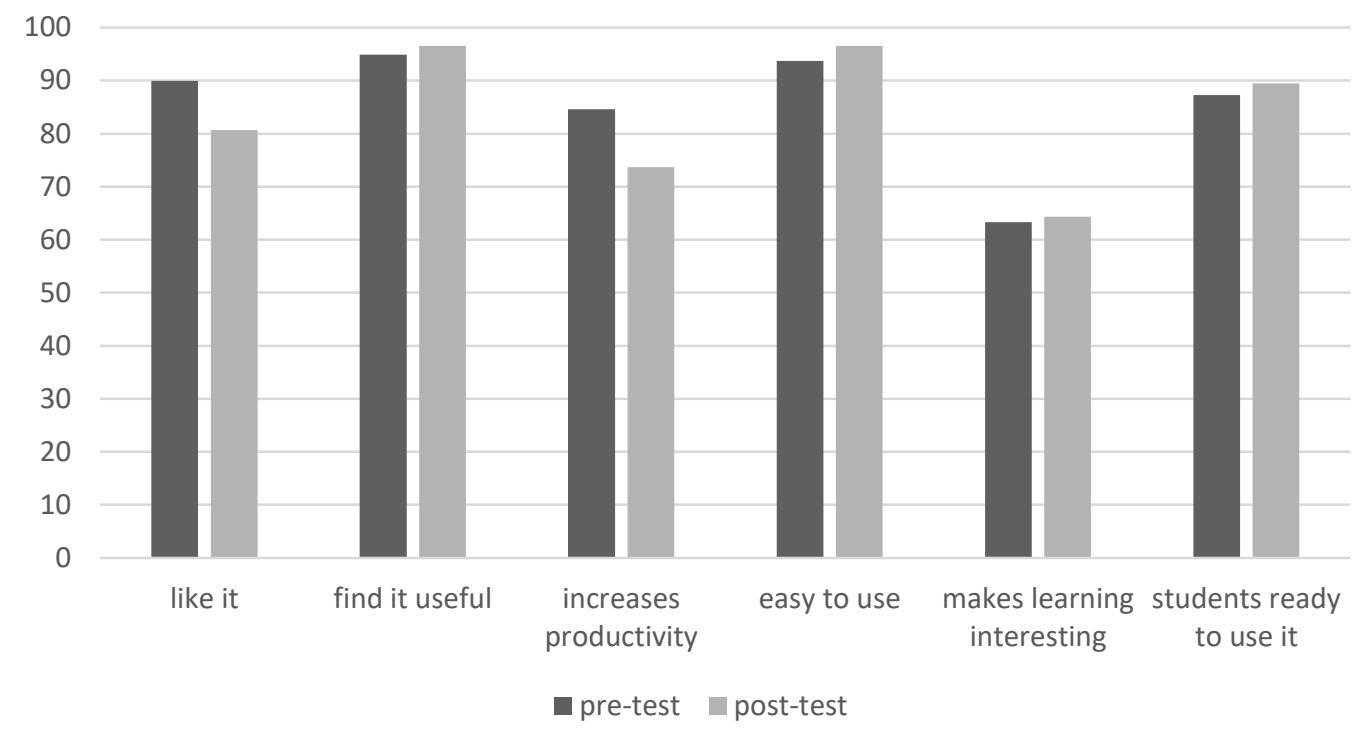

Figure 32. Students' attitudes toward Moodle

As mentioned before, students find Moodle a useful tool for learning in a blended learning environment. As a learning management system used to deliver the content and engage and motivate the study participants in the tasks, it is a platform that contains everything that is needed for realizing learning in a blended environment. In this study, students assessed their skills and knowledge needed for using Moodle as quite high. It is a user-friendly environment, but is very often used only to provide access to learning materials published by the teacher, that is as support to regular teaching (Horvat, Dobrota, Krsmanovic, \& Cudanov, 2015). This study showed that students were used to accessing Moodle several days a week, mostly for gathering information on the course, while downloading materials and uploading homework came in second and third place, respectively. These are regular tasks that the students are used to doing for the English language course, and so the results are not surprising - the teacher posts all the important information regarding the course on Moodle. 
Moodle offers various tools that were described earlier. Not all of the tools were used by the students (or the teacher). What stands out is that only one person had had any experience with wikis. However, this result was anticipated since wikis had not been used in the first semester in English and considering that students have four courses on average that use online components (of which one is English), it is very likely that very few teachers use this modality. In the study, it had been expected that the number related to the use of wikis would increase in the post-testing phase taking into consideration that the students in the BL group had to complete two wiki tasks. Yet less than $50 \%$ of BL students used wikis. However, these results are in accordance with the data obtained - only $49.29 \%$ of the students collaborated in creating the wikis, taking into consideration all the programmes. This number clearly shows that not everybody was involved in their creation. Again, the voluntary basis of these activities might have influenced the results but it does shed some light on how willing students are to work on their own, for their own learning goals.

The results based on the participants' answers to general questions about Moodle reveal that a great majority of them liked using it, and almost everybody found it useful. In addition, according to their opinion, it increased their productivity and made learning more interesting. It could be concluded that students' general attitude towards Moodle's usage was very positive. However, its actual use during the semester influenced students' opinions: there was a slight decrease in how much they liked Moodle, as well as a decrease in student productivity. This can be related to general CMC competence mentioned earlier in the chapter and the results obtained for motivation and efficiency and productivity, which were indicated as lower in the post-test stage. Nevertheless, their readiness to use it has slightly increased, which complies with results that can be found in literature (Krasnova \& Vanushin, 2016; Luk, Ng, \& Lam, 2018; Ruiz-Molina, Marín-García, \& LlopisAmorós, 2018).

The general attitude that students have towards using Moodle is very positive for its usefulness and easiness of use, but also because they believe it increases their productivity and makes learning interesting. This should also be taken into consideration again as useful information that can justify the use of Moodle at tertiary institutions - if students see it as a tool which provides them with benefits, they will be ready to use it. Even though Moodle is mostly used as a platform which 
enables students to have access to information on the course at any given time, they can also use it to download materials and upload homework and there are tools that foster interaction. This is in accordance with the literature (El-Mowafy, Kuhn, \& Snow, 2013; Kadoić \& Oreški, 2018; Korljan \& Škvorc, 2009) according to which LMSs have become an additional tool for teachers to make their materials available to students and students use it mostly prior to exams to consult the teaching materials uploaded for them by the teacher during the academic year. Students who use Moodle, regardless of their study area, generally have a positive attitude towards its usefulness and their satisfaction usually depends on how the course is organized (Cassidy, 2016; Damnjanovic, Jednak, \& Mijatovic, 2015; Gundu \& Ozcan, 2017; Xu \& Mahenthiran, 2016; Yeou, 2016). In addition, its other benefits range from increasing motivation to improving language and fostering learner autonomy (Gulbinskienè, Masoodi, \& Šliogerienè, 2017; Huang, Chen, \& Chen, 2009; Lopes, 2011; Sumtsova, et al., 2018; Stickler \& Hampel, 2010).

Their readiness to use Moodle is also visible in their use of wikis - the results of the post-testing phase show an increased usage of wikis. One conclusion here is that students are not familiar with everything Moodle has to offer; it is up to the teacher to use Moodle to the fullest so that students can benefit from the activities it offers. According to the results of the study, students are certainly ready to use Moodle. It could be postulated that a teacher familiar with all of Moodle's offerings could energetically share these with his or her students, and therefore increase student willingness to use a wider array of tools offered therein.

However, some caution is required here before drawing firm conclusions: it needs to be taken into consideration that the students that were placed in the BL group had tasks that were mandated by the teacher in order for the students to fulfil the minimum requirements of the course. It would be interesting to investigate whether the students would complete the tasks if they had the possibility to be the ones solely responsible for their learning and tasks, that is to say, if they did not have any required or obligatory tasks. This is the situation in which learner autonomy would be a necessary asset. Maybe in a different environment, with different students, the answers and, consequently, the results would be different. 
Students' use of Moodle and working in Moodle have been analysed through their activity and engagement in creation of wikis and glossary, which has been presented and discussed earlier in the chapter.

This section will present and discuss the responses given by students with regard to the general attitude towards distance/e-learning. It will also contain the results of the additional questions in the second questionnaire which was administered to the BL group of students only in the post-test stage; therefore, no comparisons could be made based on the difference between the pre-and the post-test stage for these additional questions.

The questionnaire contained seven questions that had to be answered by 'yes' or 'no'. Their purpose was to gain insight into the general attitude students have with regard to learning in a completely online environment. When asked if they had any experience in distance learning, $44.4 \%$ of them answered affirmatively. If the English language course was to be a completely online course, $67.4 \%$ of students would follow it. $92.7 \%$ of students expressed their readiness to do weekly assignments online if asked by the teacher. The majority of them $(68 \%)$ believe that it is possible to study and pass an exam without being physically present in the classroom. $78.5 \%$ of students showed their interest in following a course from their own home. When asked if they thought that distance learning was more demanding than being in the classroom, 50.8\% of them answered it was not. More of them (55.9\%) think they would not acquire the same knowledge by learning in a completely online environment when compared to the traditional way of learning, in the classroom. This is in agreement with the answer to the following question that asked about which type of learning (face-to-face or distance) they would prefer, with only $22.9 \%$ choosing distance learning.

The participants were also asked about their opinion on to what extent each of the four skills could be developed by distance learning; the answers for each of the skills were ranged from 1 to 5 , where $1=$ not at all and 5=definitely yes. As can be seen in Figure 33, they believe that writing is the skill that can be best developed $(\mathrm{M}=4.05 / \mathrm{SD}=0.96)$. This is closely followed by reading $(\mathrm{M}=3.81 / \mathrm{SD}=1.09)$ and by listening $(\mathrm{M}=3.66 / \mathrm{SD}=1.18)$. The students were less convinced that speaking can be developed by distance learning $(\mathrm{M}=2.89 / \mathrm{SD}=1.28)$. 


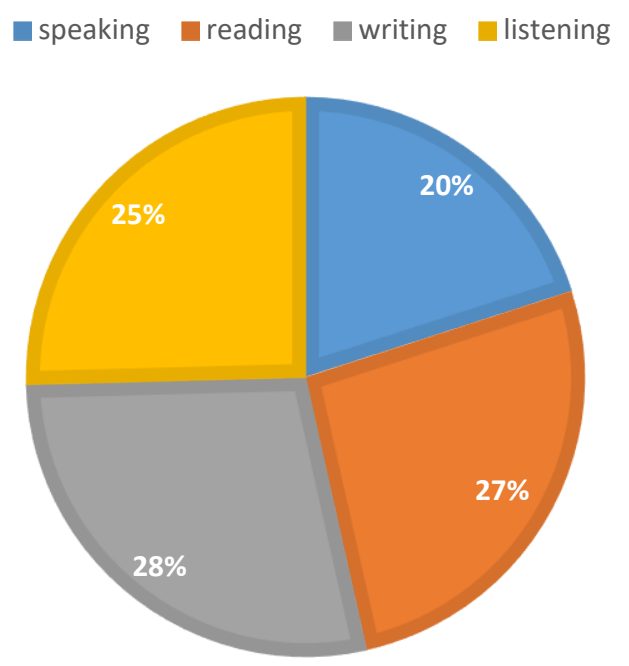

Figure 33. Skills the students believe could be developed by distance learning

\begin{abstract}
Similarly, the results obtained by the BL group show both in the pre- and post-test stages that speaking is the skill they believe would be developed the least, and the support for this belief is even lower in the post-testing phase (Figure 34). On the other hand, the students in the post-testing stage were more convinced that reading and writing could be better developed by distance learning.
\end{abstract}


5

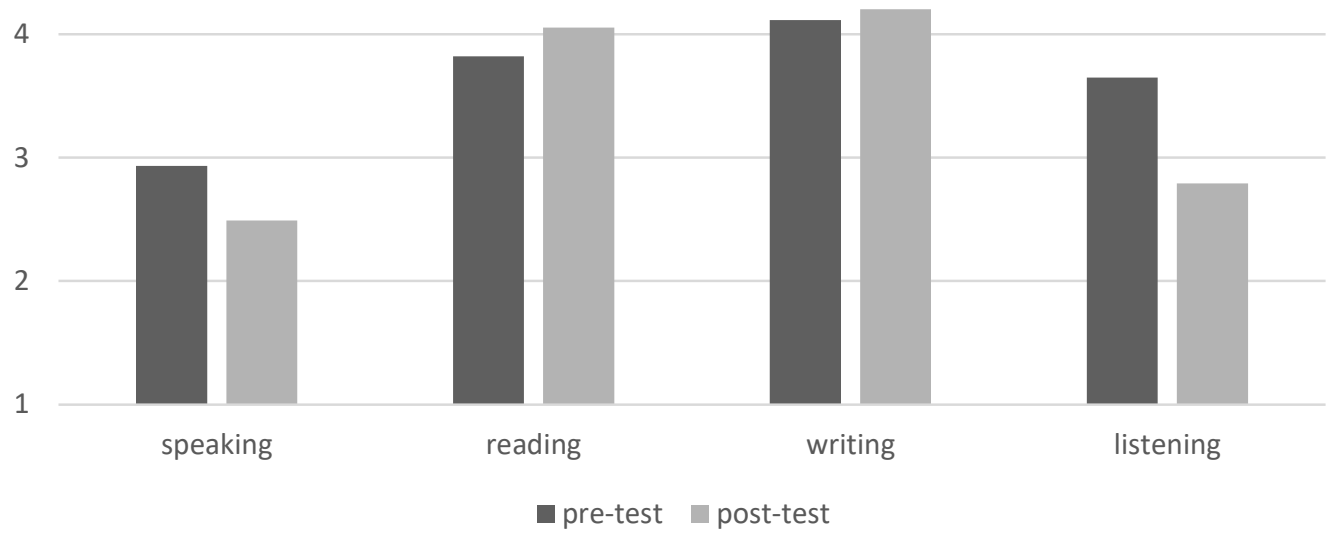

Figure 34. Comparison of skills BL students believe could be developed by distance learning in the pre-and post-test stages

When it comes to which skill students would like to develop with distance learning, their answers (expressed in median values) across both groups were close to the results presented above, with the most frequent answer being reading. When these answers are compared in both the pre- and post-testing stages of the BL group, their answers are slightly different: their most frequent answer was writing.

Even though participating and completing a course from their home is very attractive to the majority of students, around half of the students believe the knowledge acquired would be different in different learning environments (online and face-to-face). A small number of them prefer learning in an online environment. It might be assumed that they are aware of the challenges that this particular learning environment poses (their opinion on how the challenges of this mode of learning, is split) and that it requires self-discipline. This could be related to their answers with regard to skills they believe could be developed better by e-learning. Students all agree that speaking is the skill that would be most difficult to develop, while writing would be the least difficult. The results in the post-testing phase are even more positive regarding writing and less 
regarding speaking. Their experience with blended learning using Moodle makes them aware that there are fewer possibilities of developing speaking. This is probably not surprising as the focus of the study was more placed on developing reading and writing skills, as skills closely related to vocabulary acquisition. This is in line with Fučkan Držić (2009) and her research results which show that technology in general is more prone to foster written communication through reading, writing and vocabulary acquisition, while speaking is better developed through traditional teaching forms. In addition, it is useful information for teachers when designing a completely online course or a course with online elements that they need to pay attention to the opportunities for developing all fours skills equally. If we examine the analysed results of the BL groups with regard to the skill they would like to develop by distance learning in this study, they are in accordance with their wishes and beliefs.

The section of questionnaire that referred to distance and e-learning, provided an insight into general attitudes students had towards learning in a completely online environment. According to the results, more than a half of students had experience in working in online environments and expressed quite a positive attitude towards e-learning. The majority of them showed their readiness to follow the course online, and this can be applied to the English language course, even with some weekly assignments given by their teacher. This again showed their willingness to work when there is somebody who tells them what needs to be done.

As has been mentioned earlier, the students' responses to questions about their attitudes towards online and blended learning have been used to investigate student's readiness to work in an environment which is slightly different from the one they are mostly used to - a traditional classroom with the teacher teaching ex cathedra. Their opinion on learning with online components changed during the study, from the pre- to the post-testing phase - it became more positive. This leads to the conclusion that they have managed to perceive the benefits that online learning offers to students. While the students - according to their answers - still do not have much experience in distance learning and still prefer traditional way of learning, they do believe it is possible to complete a course without being present in the classroom. This leads to the conclusion that offering blended learning courses or complete online courses would be of interest to students; however, this 
might best be perceived as a way of learning that could support traditional methods of learning. The preference the students showed to learning without any online components, that is in a traditional way, became weaker at the end of the study. This should be taken into consideration by teachers/researchers when creating a particular syllabus and course. In general, their attitude towards learning English using technology is positive, but technology does not present enough of an incentive that would increase their active involvement during the course. Using technology, or learning English in a blended learning environment, has made students become more inclined towards skipping face-to-face classes when the materials are available online. They perceived this as an opportunity that gives them possibility to choose whether to be present in class or to just use the materials available on Moodle.

Students placed in the BL group were asked six additional questions which focused on students' view of particular characteristics of the blended learning environment that might have affected their attitude towards blended learning and face-to face learning environments. $51.9 \%$ of them did not miss being physically present in the classes, but $59.3 \%$ said they missed regular contact with the teacher. They were also asked in which of the two teaching contexts (face-to-face or online) they received better feedback. The results show that $69.8 \%$ of them consider that the feedback was better in the face-to-face teaching environment. Only $46.3 \%$ of them believe they improved their language.

In the final section of the questionnaire in the post-testing stage six questions had been added with the purpose of providing insight into the experience they had with learning English in a blended learning environment, particularly with regard to interaction, feedback, improvement of their language and learner autonomy. Even though students did not miss being physically present in the class, they did miss the direct contact with the teacher. According to the results, the teacher's presence in the class is still desirable. This could speak in favour of blended learning since it enables a certain amount of time where students are in direct contact with the teacher. The results have shown that this direct interaction with the teacher provided them with better feedback, even though the teacher was ready to give them feedback if needed whether on the forum or Skype, but neither of these tools were used by students. 
The purpose of this chapter was to present the results of this study and to discuss how they are related to, and aligned with, the literature in the area of blended learning, vocabulary acquisition and learner autonomy. After analysing data using the statistical computing language $\mathrm{R}$ (R Core Team, 2017), a significant amount of valuable information was gathered. The results have been presented to support the hypotheses set at the beginning of the research. Upon describing the demographic details of the participants, various aspects of the research have been made known that relate to each of the notions mentioned in the title of the thesis.

The overall aim of this study was to investigate how technology used in a blended learning environment at a tertiary education institution could affect language learning, vocabulary acquisition in particular, and how it could influence a learner's development of autonomy. For the purpose of this investigation, the students of University North studying at five different technical undergraduate programmes were chosen as a convenient sample. By separating them into two groups (a blended learning group and a face-to-face group) and assigning the blended learning group three tasks to be done online (creating two wikis and a glossary), it was possible to conduct the research and compare the results of the two groups. In addition, the groups were asked to fill in a questionnaire - both groups at the beginning and the blended learning group only at the end of semester. The responses obtained by the questionnaire gave insights into how students use technology, for which purposes, and how they feel about learning in a blended learning or a completely online environment, and using Moodle for the purpose of English language learning in particular. Not all of the findings are directly related to the hypotheses, but they are perceived as useful because they give a more complete picture of learning in a blended environment.

To sum up, based on the study conducted and described in Chapter 4 and the results that were discussed following its analysis, it may reasonably be concluded that students in a blended learning environment are able to acquire vocabulary to the same extent as those in a traditional face-to-face learning environment; the group to which they belonged was of no significance. The students involved in online learning were aware of the possibilities that blended learning offered through their use of Moodle, but they were ready to use only those that were assigned by the teacher. The students learning in a blended learning environment were not aware of any improvements in their 
language skills, but were aware of the possibility of developing learner autonomy through technology and distance learning. The only barriers that stood in the way of becoming autonomous and independent in their learning were students themselves. It is logical, then, to recognize that once students are finally able to realize that they are (or should be) responsible for their learning, only then can they start learning for themselves, becoming intrinsically motivated and not feeling obligated out of regard for the teacher, or merely passing the course. If they become aware of, and then use, the opportunities afforded them by their teacher, they can start developing and fostering their learner autonomy. The teacher who is educated and informed enough to offer such opportunities is surely the one who is ready to help and guide such a learner. 


\section{CONCLUSION}

This final chapter will aim to summarise the main conclusions of the study, together with its theoretical and practical implications, but also its limitations.

The results of the study have demonstrated that professional vocabulary can be acquired in a blended learning environment to the same extent as in a traditional learning environment. Exposure to professional vocabulary through engagement in different activities, such as wikis and glossary, in a blended learning environment has shown to be sufficient for the students to acquire vocabulary, even without the teacher's direct assistance. In addition, the blended learning environment has shown to be an environment in which students have the opportunity to use different methods of interaction by using a computer as a mediating tool with which they can interact as many times as needed. This has enabled the students to acquire vocabulary at their own pace and has helped them mediate their own learning in an effort to reach self-regulation, that is to use the knowledge without anybody's assistance. However, in order to reach this level of autonomy, the teacher needs to be involved in the process from the beginning - from designing the tasks as required by the learners' needs and preferences, for example in terms of supervision and moderation to giving feedback since it is not very likely that a learner can become autonomous simply by being placed in a learning situation. The teacher's goal is to support the learner in this process and to ensure that all students receive appropriate input in accordance with the desired output. This implies that direct interaction between the teacher and the student is crucial in the beginning of the process, when the student needs more guidance, whereas later this interaction can be minimized and the student can focus more on interaction with their peers or with the computer. In this way, they become responsible for their own learning. Moreover, it suggests that the roles learners and teachers have in the learning process are complementary in learner autonomy development. The students' activity in completing the tasks has been perceived as taking control of their own learning and thus as an act of autonomous learning encouraged by using $\mathrm{CMC}$ tools in a blended learning environment which has proven to be an environment where students can learn at their own pace, they can collaborate and receive feedback. It is significant to notice that the majority of the students in the BL group think that learning in an online environment develops learner autonomy, which indicates that they are aware of this affordance of the blended learning environment. However, a certain level of 
technology skills is expected of students so they could be successful in working in such an environment. Even though the results of this study have shown that there is an improvement in professional vocabulary knowledge, there is no evidence of any kind of association between technical competencies and professional vocabulary scores at the end of the semester. Therefore, a higher level of technological competence does not necessarily imply a higher level of vocabulary acquisition in a blended learning environment.

If we go back to Larsen-Freeman (2018) and her vision of the future of research in SLA, this study and it results contribute to research of new technologies and how they open up new possibilities for language learning directed towards virtual spaces, whether it be by using computers or mobile phones. This has proven useful in today's pandemic times, where teaching is mainly done in online or in different blended environments. By placing the focus of this study on using technology for the purposes of second language acquisition, with specific emphasis on changing the approach to the acquisition of vocabulary in the context of English for specific purposes, its results can be perceived as contributing to the research in this field.

\subsection{Theoretical and Practical Implications}

The main motivation behind this study was to determine the role of blended learning in vocabulary acquisition and the development of learner autonomy of higher education students in an ESP context. This, in turn, would help provide theoretical and practical evidence to support more frequent use of technology in its various forms in the English language classroom, to promote student collaboration at a tertiary level, especially for the purpose of vocabulary acquisition, which would consequently enable students to display a greater degree of control over their language learning.

The study with its results and conclusions described in the previous sections enabled a deeper insight into the effect of a blended learning model in comparison with the traditional approach to acquisition of specific purposes vocabulary at a higher-education institution. The vocabulary in question had a professional focus and the study was related to the programme in which the students were enrolled. 
At the same time, the study provided insight into the process of how language input transfers to intake, that is, how new linguistic information can be noticed by its use in a new linguistic situation. By relying on their extra-linguistic knowledge, the participants were exposed to comprehensible input which was varied based on the learning environment. New linguistic information in a blended learning environment was noticed by the students through its use in wikis and in the creation of a glossary and thus transferred to intake. This process was visible through the students' output in the form of the content published on Moodle and in the results of the vocabulary tests.

The contribution of this study to SLA research can be noticed in proving that exposure to input, which is necessary for SLA, leads toward language development, or in this case vocabulary acquisition. Learners were exposed to input in two different learning environments (face-to-face and blended) in a different way and to a different extent. The blended learning environment has proven to be as efficient for vocabulary acquisition as face-to-face environment. Additionally, knowing that a good deal of SLA happens incidentally, participants in this research had a task of reading texts related to their professional engineering topics while looking for examples of conditional sentences. At the same time, they were exposed to input and had to focus on the message that the texts they were reading contained. By looking for conditional sentences in texts on various websites, they were additionally exposed to input which could be called comprehensible due to its nature: familiar content related to the students' professions not filtered according to their language level like in language learning books. It is not crucial to understand all the language we are exposed to (input), but that portion that we can understand and therefore use for acquisition is actually comprehensible and can be referred to as intake (Truscott \& Sharwood Smith, 2011). If we want this intake to turn into output, as in this study (via wikis or a glossary), teachers should pay special attention to the materials used for teaching a language because students need to understand them enough for their language acquisition.

To sum up, the learner needs to be exposed to language in order to produce language. Therefore, input and output are both realized through interaction, whether it is an interaction between learner and learner or learner and computer, or through the blended learning environment. Very often 
meaning is negotiated, or adapted for the learner during interaction. This is when the learner can learn a language - by communicating.

The study contributes to how knowledge is acquired on how blended learning contributes to foreign language acquisition, especially regarding learner autonomy, and to the successful acquisition of foreign vocabulary in a blended learning environment compared to traditional classroom learning. This generally contributes to the knowledge about second language vocabulary acquisition. The results which show that vocabulary can be acquired even in a blended learning environment also contribute to teaching practice and aid part-time students due to the existence of evidence that their absence from regular face-to-face English lessons does not necessarily have a detrimental effect on their learning. With regard to teaching practice, there is no reason why blended learning should not be more used at higher-education institutions and for the purposes of language learning. In addition, the use of technology and learning in a blended learning environment has shown that learners as members of a group can create content based on existing materials which can be later used as learning materials.

This study has also shown that learner autonomy is a concept which can be expressed through learner's awareness, which presupposes pedagogical goal and content. Even though it is difficult to measure it, by collecting information on learners' activity in a blended learning environment, learner autonomy can be detected through the number of times they work on a task to complete it. By raising students' awareness of their responsibility for their own learning, they can be actively involved in fostering learner autonomy.

Before closing this section, I would like to make some remarks regarding certain issues I have noticed in my teaching career that motivated me to conduct this study. The students who mostly rely on materials published on Moodle are getting sufficient input to improve their language level and pass the exam at the end of the course. This is supported by the vocabulary test results which indicate students' progress with regard to ESP vocabulary. The teaching environment to which they are exposed does not significantly affect their success in vocabulary developments and the output or language that the students of the BL group produce at the end of the course is very similar to the output of colleagues which are present in classes for most of the time. This is visible in the 
vocabulary test results which show that both groups of students, the $\mathrm{FtF}$ and the BL group managed

to develop vocabulary form the beginning to the end of semester. Therefore, they acquire the same amount of vocabulary and their language is improving even though they mostly work on their own, which means they need to be responsible for their own learning and a level of learner autonomy is required. For the moment, it seems that not all of them are autonomous enough to be able to fulfil their obligations they have as students of the course. However, this is something that can be worked on with the help of the teacher as a person whose task is to adapt teaching to individual needs of students in order to facilitate their language development. This can be aided by using technology and all the affordances it offers, one of them being working in a rich blended learning environment. Since the students' technological literacy skills are developed sufficiently to work in a blended learning environment and they are willing to work and are motivated to interact among themselves and with the teacher, this should not be a problem at all.

\subsection{Limitations}

The study has been shown to have some limitations and in case of its replication, several points should be considered.

Technology is ever evolving so changes in technology usage over time are quite common. Due to the fact that the research was conducted five years ago, it is to be expected that the attitude towards using technology is likely to have changed, especially towards particular types of technology, and in light of the recent global COVID-19 pandemic. In addition, changing technology offers new opportunities for language learning that could be used and included in the research.

The logs that would shed some light on individual work done by students would have been of great use. Unfortunately, the policy of the University had not been taken into consideration which meant that all Moodle logs were deleted on a regular basis to gain more virtual space. For that reason, only the history of editing wikis and the glossary were available. The available data led to some conclusions, but they would have been more detailed and precise if logs had been available.

A number of students who participated in the study did not do all the activities that they had been asked to do (e.g. they did not fill in the necessary forms). This meant that it was impossible to draw 
more specific conclusions, especially regarding the difference between the pre- and post-testing phases of research. A certain amount of data was not available due to some students not being present at the beginning and the end of the course for various reasons. This was a possibility that should have been predicted by the researcher, since the study involved students for whom it was not compulsory to participate in all activities. Just asking potential participants is not always sufficient. If this study is ever to be replicated, the researcher should find a way of ensuring that participants commit themselves to participating fully.

It would also have been useful to organize focus groups with the $\mathrm{FtF}$ group to gain insight into how they perceived the work of their colleagues and how useful it was for them (if at all) when preparing for the exam.

The course was not organized so as to foster the development of all four skills in a blended learning environment - it focused on reading and writing only, while speaking and listening were excluded. It would be interesting to see how other skills, such as speaking, could be developed in a blended learning environment and what the perception of students would be with regard to the possibilities blended learning environment has to offer.

Learner autonomy has proven to be a construct difficult to measure. The conclusions related to learner autonomy have been made on the basis of the responses given by students in the questionnaire, thus rendering this concept qualitative. Even though more comprehensive conclusions could not be made, this study has shed some light on the crucial role that the teacher has in the development of learner autonomy as someone who supports the learners in the initial stages by making them aware of what they can do on their own and how. The study has also shown how vocabulary acquisition can be facilitated by digital tools that permeate all spheres of learning today - tools which can open up learning beyond the physical classroom and also make learning more interesting for a generation that has grown up with these technologies. These tools can be combined with face-to-face learning to create a blended learning environment, which has proven to be an environment that can support vocabulary acquisition and learner autonomy development. 


\section{REFERENCES}

Abdi, H. (2007). Kendall Rank Correlation. In N. J. Salkind (Ed.), Encyclopedia of measurement and statistics (pp. 508-510). Thousand Oaks, CA: Sage Publications.

Adamson, B. (2004). Fashions in Language Teaching Methodology. In A. Davies, \& C. Elder (Eds.), The Handbook of Applied Linguistics (pp. 604-622). Blackwell Publishing Ltd.

Ageel, M., \& Woollard, J. (2012). Enhancing University Teachers' Information and Communication Technology Usage by Using a Virtual Learning Environment Training Course. Proceedings of INTED2012 Conference. 5th-7th March 2012, Valencia, Spain, (pp. 5599-5606).

Agosto, D. E., Copeland, A. J., \& Zach, L. (2013). Testing the Benefits of Blended Education: Using Social Technology to Foster Collaboration and Knowledge Sharing in Face-to-Face LIS Courses. Journal of Education for Library and Information Science, 54(2), pp. 94-107.

Ahmad, J. (2012). Intentional vs. incidental vocabulary learning. ELT Research Journal, 1(1), pp. 71-79.

Ajideh, P. (2009). Autonomous Learning and Metacognitive Strategies Essentials in ESP Class. English Language Teaching, 2(1), pp. 162-168.

Akbari, E., Pilot, A., \& Simons, P. R.-J. (2016). Autonomy, competence, and relatedness in foreign language learning. Computers in Human Behavior, 48, pp. 126-134.

Al Hinai, I. (2018). The Omani Technical Students' Knowledge of English for Specific Purposes (ESP) Lexis and Their Attitudes Towards Learning ESP. Sino-US English Teaching, 15(10), pp. 483-512.

Alali, F. A., \& Schmitt, N. (2012). Teaching Formulaic Sequences: The Same as or Different from Teaching Single Words? TESOL Journal, 3(2), pp. 153-180.

Aldunate, R., \& Nussbaum, M. (2013). Teacher adoption of technology. Computers in Human Behavior, 29, pp. 519-524.

Alharbi, M. A. (2016). Using different types of dictionaries for improving reading comprehension and vocabulary acquisition in English as a foreign language programs. The JALT CALL Journal, 12(2), pp. 103-122.

Allum, P. (2004). Evaluation of CALL: Initial vocabulary learning. ReCALL, 16(2), pp. 488-501. doi:10.1017/S0958344004001624

Alqahtani, M. A. (2015). Teaching English for Specific Purposes: Attitudes among Saudi Engineering Students. English Language Teaching, 8(7), pp. 76-94. doi:10.5539/elt.v8n7p76 
Amengual-Pizarro, M. (2017). Engineering students' motivational variables towards English and the learning of the English language. Revista de Lenguas para Fines Especificos, 23(1), pp. 31-44. http://dx.doi.org/10.20420/rlfe.2017.156

Ardeo, J. M. (2016). Learning motivation and strategies of ESP university students. Revista de Lenguas para Fines Especificos, 22(1), pp. 141-169.

Arnó Macià, E. (2012). The Role of Technology in Teaching Languages for Specific Purposes Courses. The Modern Language Journal, 96, pp. 89-104.

Arnold, J., \& Fonseca-Mora, C. (2015). Language and cultural encounters: Opportunities for interaction with native speakers. In D. Nunan, \& J. Richards (Eds.), Language Learning Beyond the Classroom (pp. 225-234). New York: Taylor \& Francis, Routledge.

Arslan, M. U., \& Akbarov, A. (2012). EFL Learners Perceptions and Attitudes towards English for the Specific Purposes. Acta Didactica Napocensia, 5(4), pp. 25-30.

Azmi, N. (2017). The Benefits of Using ICT in the EFL Classroom: From Perceived Utility to Potential Challenges. Journal of Educational and Social Research, 7(1), pp. 111-118.

Bailin, A. (1995). Intelligent computer-assisted language learning: A bibliography. Computers and the Humanities, 29(5), pp. 375-387.

Bañados, E. (2006). A Blended-learning Pedagogical Model for Teaching and Learning EFL Successfully Through an Online Interactive Multimedia Environment. CALICO Journal, 23(3), pp. 533-550.

Banditvilai, C. (2016). Enhancing Students' Language Skills through Blended Learning. The Electronic Journal of e-Learning, 14(3), pp. 220-229.

Barber, W., DiGiuseppe, M., van Oostveen, R., Blayone, T., \& Koroluk, J. (2016). Examining Student and Educator use of Digital Technology in an Online World. Higher Education in Transformation Symposium, November 2-6, Oshawa, Ontario, Canada.

Barsotti, C., \& Martins, C. (2011). The Use of ICTs in Foreign Language Teaching: The Challenges of a Teachers' Education Program: Carla Barsotti and Claudia Martins. In M. Levy, F. Blin, C. B. Siskin, \& O. Takeuchi (Eds.), WorldCALL: International Perspectives on Computer-Assisted Language Learning (pp. 241-256). Routledge.

Bates, A. W. (2005). Technology, E-learning and Distance Education. Oxon: Routledge.

Bax, S. (2003). CALL - past, present and future. System, 31(1), pp. 13-28.

Beatty, K. (2010). Teaching and Researching Computer-Assisted Language Learning. Pearson Education Limited. 
Bekar, M., \& Christiansen, M. S. (2018). Computer-Mediated Communication (CMC). In J. I. Liontas, T. I. Association, \& M. DelliCarpini (Eds.), The TESOL Encyclopedia of English Language Teaching. John Wiley \& Sons, Inc.

Belcher, D. (2013). The Future of ESP Research: Resources for Access and Choice. In B. Paltridge, \& S. Starfield (Eds.), The Handbook of English for Specific Purposes (pp. 535-552). WileyBlackwell.

Belz, J. A. (2003). Linguistic perspectives on the development of intercultural competence in telecollaboration. Language Learning \& Technology, 7(2), pp. 68-117. doi:10125/25201

Benson, P. (2007). Autonomy in language teaching and learning. Language Teaching, 40, pp. 2140. doi:10.1017/S026144480600395

Benson, P. (2013). Teaching and Researching Autonomy. London and New York: Routledge.

Benson, P., \& Voller, P. (Eds.). (2013). Autonomy and Independence in Language Learning. Oxon: Routledge.

Benson, P., Grabe, W., \& Stoller, F. L. (2001). Teaching and Researching Autonomy in Language Learning. Harlow, England: Pearson Education Limited.

Blackburn, H. (2017). The Status of Women in STEM in Higher Education: A Review of the Literature 2007-2017. Science \& Technology Libraries, 36(3), pp. 235-273.

Blake, R. J. (2009). The use of technology for second language distance learning. Modern Language Journal, 93, pp. 822-835.

Blake, R. J. (2011). Current Trends in Online Language Learning. Annual Review of Applied Linguistics (31), pp. 19-35.

Bloch, J. (2002). Student/teacher interaction via email: the social context of Internet discourse. Journal of Second Language Writing, 11(2), pp. 117-134.

Bloch, J. (2013). Technology and ESP. In B. Paltridge, \& S. Starfield (Eds.), The Handbook of English for Specific Purposes (pp. 385-401). Chichester: Wiley-Blackwell.

Bobera, D., Sakal, M., Tumbas, P., \& Matković, P. (2015). Innovation Opportunities Offered by Wikis in Higher Education Courses: Implementation Modelling. Croatian Journal of Education, 17(3), pp. 261-295.

Bojović, M. (2006). Teaching Foreign Language for Specific Purposes: Teacher Development. The proceedings of the 31st Annual Association of Teacher Education in Europe Conference, (pp. 487493). 
Bošković, V., Gajić, T., \& Tomić, I. (2014). Moodle in English Language Teaching. SINTEZA 2014: Impact of Internet on Business Activities in Serbia and Worldwide (pp. 480-483). Beograd: Univerzitet Singidunum.

Bourne, J. R., \& Moore, J. C. (Eds.). (2005). Elements of Quality Online Education: Engaging Communities. Sloan-C.

Bovtenko, M. A., \& Parshukova, G. B. (2018). Subject MOOCs as Component of Language Learning Environment. In A. Filchenko, \& Z. Anikina (Ed.), Linguistic and Cultural Studies: Traditions and Innovations. LKTI 2017. Advances in Intelligent Systems and Computing, vol 677 (pp. 122-127). Springer, Cham. https://doi.org/10.1007/978-3-319-67843-6_15

Bowen, W. G. (2013). Higher Education in the Digital Age. Princeton and Oxford: Princeton University Press.

Brahja, A. (2013). ESP Vocabulary Teaching and Learning, Comparing the Language Teacher and Language Learning on the Internet. Journal of Educational and Social Research, 3(7), pp. 655661. doi:10.5901/jesr.2013.v3n7p655

Brahmi, F. (2016). Can Facebook or wikis hook learners instead of the schoolbook? In C. Goria, O. Speicher, \& S. Stollhans (Eds.), Innovative language teaching and learning at university: enhancing participation and collaboration (pp. 65-72). Dublin: Research-publishing.net.

Breeze, R. (2014). Moodle Glossary Tasks for Teaching Legal English. In E. Bárcena, T. Read, \& J. Arús (Eds.), Languages for Specific Purposes in the Digital Era (pp. 111-128). Cham: Springer.

Brooks, D. C., \& Pomerantz, J. (2017). ECAR Study of Undergraduate Students and Information Technology, 2017. Research report. Louisville, CO: ECAR.

Brown, J. D. (2016). Introducing Needs Analysis and English for Specific Purposes. Routledge.

Brown, R. (1973). A First Language: The Early Stages. Cambridge, Massachusetts: Harvard University Press.

Brunton, M. (2009). An account of ESP - with possible future directions. English for Specific Purposes, 8(24).

Bueno-Alastuey, M. C., \& López Pérez, M. (2014). Evaluation of a blended learning language course: students' perceptions of appropriateness for the development of skills and language area. Computer Assisted Language Learning, 27(6), pp. 509-527.

Bunz, U., \& Montez, D. (2015). Computer-mediated communication competence. In A. F. Hannawa, \& B. H. Spitzberg (Eds.), Communication Competence (pp. 153-190). Berlin: De Gruyter Mouton. 
Buran, A., \& Evseeva, A. (2015). Prospects of Blended Learning Implementation at Technical University. Procedia - Social and Behavioral Sciences, 206, pp. 177-182.

Bytheway, J. (2015). A taxonomy of vocabulary learning strategies used in massively multiplayer online role-playing games. CALICO Journal, 32(3), pp. 508-527.

Cachia, R., Ferrari, A., Ala-Mutka, K. M., \& Punie, Y. (2010). Creative Learning and Innovative Teaching: Final Report on the Study on Creativity and Innovation in Education in the EU Member States. Publications Office of the European Union.

Carver, D. (1983). Some propositions about ESP. English for Specific Purposes, 2, pp. 131-137.

Cassidy, S. (2016). Virtual Learning Environments as Mediating Factors in Student Satisfaction with Teaching and Learning in Higher Education. Journal of Curriculum and Teaching, 5(1), pp. 113-123.

Chacón-Beltrán, R. (2017). The Role of MOOCs in the Learning of Languages: Lessons from a Beginners' English Course. Porta Linguarum (28), pp. 23-35.

Chambers, A. (2001). Introduction. In A. Chambers, \& G. Davies (Eds.), ICT and Language Learning: a European Perspective (pp. 7-12). Swets \& Zeitlinger.

Chapelle, C. (1997). CALL in the Year 2000: Still in Search of Research Paradigms? Language Learning \& Technology, 1(1), pp. 19-43.

Chapelle, C. (1998). Multimedia CALL: Lessons to be learned from research on instructed SLA. Language Learning \& Technology, 2(1), pp. 21-39. http://dx.doi.org/10125/25030

Chapelle, C. (2001). Computer applications in second language acquisition: Foundations for teaching, testing, and research. Cambridge: Cambridge University Press.

Chapelle, C. A. (1990). The Discourse of Computer-Assisted Language Learning: Toward a Context for Descriptive Research. TESOL Quarterly, 24(2), pp. 199-225.

Chapelle, C. A. (2005). Interactionist SLA Theory in CALL Research. In J. Egbert, \& G. M. Petrie (Eds.), CALL research perspectives (pp. 53-64). Mahwah, New Jersey: Lawrence Erlbaum Associates, Inc.

Chapelle, C. A. (2009). Language Acquisition Theory and Computer-Assisted Language Learning. The Modern Language Journal, 93, pp. 741-753.

Chapelle, C. A. (2010). The spread of computer-assisted language learning. Language Teaching, 43, pp. 66-74.

Chapelle, C. A. (2016). CALL in the Year 2000: A Look Back from 2016. Language Learning \& Technology, 20(2), pp. 159-161. 
Chen, Y. (2012). Dictionary Use and Vocabulary Learning in the Context of Reading. International Journal of Lexicography, 25(2), pp. 216-247.

Cheung, C. M., Chiu, P.-Y., \& Lee, M. K. (2011). Online social networks: Why do students use Facebook? Computers in Human Behavior, 27(4), pp. 1337-1343.

Chirimbu, S., \& Tafazoli, D. (2014). Blending Learning: Bridging the Motivational Gap in ESP Courses. eLearning \& Software for Education (2), pp. 67-71.

Chiu, Y.-H. (2013). Computer-assisted second language vocabulary instruction: A meta-analysis. British Journal of Educational Technology, 44(2), pp. E52-E56.

Chu, S. K., Chu, Y., Chen, K., Chan, C. K., Lee, C. W., Zou, E., \& Lau, W. (2017). The effectiveness of wikis for project-based learning in different disciplines in higher education. Internet and Higher Education, 33, pp. 49-60.

Chun, D., Kern, R., \& Smith, B. (2016). Technology in Language Use, Language Teaching, and Language Learning. Modern Language Journal, 100, pp. 64-80.

Chung, T. M., \& Nation, P. (2004). Identifying technical vocabulary. System 32, pp. 251-263.

Ciglar, V. (1982). Osnovni problemi nastave stranih jezika u organizacijama udruženog rada visokog obrazovanja. Journal of Information and Organizational Sciences (6), pp. 345-357. Retrieved from https://hrcak.srce.hr/81021

Cilliers, L. (2016). Wiki acceptance by university students to improve collaboration in higher education. Innovations in Education and Teaching International. Retrieved from http://dx.doi.org/10.1080/14703297.2016.1180255

Compton, L. K. (2009). Preparing language teachers to teach language online: a look at skills, roles, and responsibilities. Computer Assisted Language Learning, 22(1), pp. 73-99.

Cook, V. (1993). Linguistics and Second Language Acquisition. London: Palgrave. https://doi.org/10.1007/978-1-349-22853-9

Cook, V. (2003). Introduction: The Changing L1 in the L2 User's Mind. In V. Cook (Ed.), Effects of the Second Language on the First (pp. 1-18). Multilingual Matters Ltd.

Corder, S. (1975). Error Analysis, Interlanguage and Second Language Acquisition. Language Teaching, 8(04), pp. 201 - 218. https://doi.org/10.1017/S0261444800002822

Cornillie, F., Thorne, S. L., \& Desmet, P. (2012). ReCALL special issue: Digital games for language learning: challenges and opportunities: Editorial Digital games for language learning: from hype to insight? ReCALL, 24(3), pp. 243-256. 
Coryell, J. E., \& Chlup, D. T. (2007). Implementing E-Learning components with adult English language learners: Vital factors and lessons learned. Computer Assisted Language Learning, 20(3), pp. 263-278.

Cox, M. J. (2013). Formal to informal learning with IT: research challenges and issues for elearning. Journal of Computer Assisted Learning, 29(1), pp. 85-105.

Coxhead, A. (2013). Vocabulary and ESP. In B. Paltridge, \& S. Starfield (Eds.), The Handbook of English for Specific Purposes (pp. 115-132). Chichester, Wiley-Blackwell.

Crawford, J. (2002). The Role of Materials in the Language Classroom: Finding the Balance. In J. C. Richards, \& W. A. Renandya (Eds.), Methodology in English Teaching. An Anthology of Current Practice (pp. 80-89). Cambridge: Cambridge University Press.

Czellér, M., Hajdú, Z., \& Wiwczaroski, T. B. (2015). Blended learning incorporated into courses teaching English for specific purposes. English for Specific Purposes World. Special Issue \#1, 16. Retrieved from www.esp-world.info

Čonková, M. (2013). Analysis of Perceptions of Conventional and E-Learning Education in Corporate Training. Journal of Competitiveness, 5(4), pp. 73-97. doi:10.7441/joc.2013.04.05

Dahlstrom, E., Walker, J. D., \& Dziuban, C. (2013). The ECAR Study of Undergraduate Students and Information Technology, 2013. Boulder, Colorado: EDUCAUSE Center for Applied Research.

Dam, L., \& Legenhausen, L. (1996). The acquisition of vocabulary in an autonomous learning environment - the first months of beginning English. In R. Pemberton, E. S. Li, W. W. Or, \& H. D. Pierson (Eds.), Taking Control: Autonomy in Language Learning (pp. 265-280). Hong Kong: Hong Kong: University Press.

Dam, L., Eriksson, R., Little, D. M., \& Trebbi, T. (1990). Towards a definition of autonomy. In T. Trebbi (Ed.), Third Nordic Workshop on Developing Autonomous Learning in the FL Classroom, Bergen, August 11-14, 1989: Report (pp. 102-103). Bergen, Norway: Institutt for praktisk pedagogikk, Universitet i Bergen. (Mimeo).

Damnjanovic, V., Jednak, S., \& Mijatovic, I. (2015). Factors affecting the effectiveness and use of Moodle: students' perception. Interactive Learning Environments, 23(4), pp. 496-514. doi:10.1080/10494820.2013.789062

Dashtestani, R., \& Stojković, N. (2015). The Journal of Teaching English for Specific and Academic Purposes, 3(3), pp. 435-456.

Davies, P. H. (2002). Intelligence, information technology, and information warfare. Annual Review of Information Science and Technology, 36(1), pp. 312-352. 
de Almeida Mello, G. N. (2017). Activities based on wiki platform for engineering higher education: students' point of view. RIAEE - Revista Ibero-Americana de Estudos em Educação, 12(2), pp. 1331-1348.

Deutschmann, M., \& Vu, M. T. (2015). Computer assisted language learning in language education: an overview of theories, methods, and current practices. In E. Lindgren, \& J. Enever (Eds.), Språkdidaktik: researching language teaching and learning (pp. 43-60). Umeå: Department of Language Studies, Umeå University.

Dickinson, L. (1994). Learner autonomy: what, why and how? In V. J. Leffa (Ed.), Autonomy in Language Learning (pp. 2-12). Porto Alegre: Ed. Universidade.

Dickinson, L. (1995). Autonomy and motivation a literature review. System, 23, pp. 165-174. https://doi.org/10.1016/0346-251X(95)00005-5

Donato, R., \& McCormick, D. (1994). A Sociocultural Perspective on Language Learning Strategies: The Role of Mediation. The Modern Language Journal, 78(iv), pp. 453-464.

Dooly, M. (2009). New competencies in a new era? Examining the impact of a teacher training project. ReCALL, 21(3), pp. 352-369.

Drysdale, J. S., Graham, C. R., Spring, K. J., \& Halverson, L. R. (2013). An analysis of research trends in dissertations and theses studying blended learning. Internet and Higher Education, 17, pp. $90-100$.

Dudeney, G., \& Hockly, N. (2012). ICT in ELT: how did we get here and where are we going? ELT Journal, 66(4), pp. 533-542.

Dudley-Evans, T., \& St John, M. J. (1998). Developments in English for Specific Purposes: A Multidisciplinary Approach. Cambridge: Cambridge University Press.

Duhaney, D. C. (2004). Blended learning in education, training, and development. Performance Improvement, 43(8), pp. 35-38.

Duncan-Howell, J. (2010). Teachers making connections: Online communities as a source of professional learning. British Journal of Educational Technology, 41(2), pp. 324-340.

Dunkel, P. (1990). Implications of the CAI Effectiveness Research for Limited English Proficient Learners. Computers in the Schools, 7(1-2), pp. 31-52.

Dziuban, C., Moskal, P., \& Hartman, J. (2005). Higher education, blended learning, and the generations: Knowledge is power: No more. In J. Bourne, \& J. Moore (Eds.), Elements of Quality Online Education: Engaging Communities. Sloan-C. 
Egbert, J. L. (2005). Conducting research on CALL. In J. L. Egbert, \& G. M. Petrie (Eds.), CALL research perspectives (pp. 3-8). Mahwah, New Jersey: Lawrence Erlbaum Associates, Inc., Publishers.

Ellis, R. (1991). The Interaction Hypothesis: A Critical Evaluation. Retrieved from https://eric.ed.gov/?id=ED338037

Ellis, R. (1994). The Study of Second Language Acquisition. Oxford: OUP.

Ellis, R. (1997). Second Language Acquisition. Oxford: Oxford University Press.

Ellis, R. (2008). The study of second language acquisition. Oxford: Oxford University Press.

Ellis, R. (2010). Second language acquisition, teacher education and language pedagogy. Language Teaching, 43(2), pp. 182-201.

Ellis, R., Skehan, P., Li, S., Shintani, N., \& Lambert, C. (2019). Sociocultural Perspectives. In Task-Based Language Teaching: Theory and Practice (Cambridge Applied Linguistics, pp. 103128). Cambridge: Cambridge University Press. doi:10.1017/9781108643689.008

El-Mowafy, A., Kuhn, M., \& Snow, T. (2013). Blended learning in higher education: Current and future challenges in surveying education. Issues in Educational Research, 23(2), pp. 132-150.

Ernest, P., Guitert, M., Hampel, R., Heiser, S., Hopkins, J., Murphy, L., \& Stickler, U. (2012). Online teacher development: collaborating in a virtual learning environment. Computer Assisted Language Learning, pp. 1-23.

Ernest, P., Heiser, S., \& Murphy, L. (2013). Developing teacher skills to support collaborative online language learning. The Language Learning Journal, 41(1), pp. 37-54.

Fabbri, M. (2018). Forums as a tool for negotiating knowledge in Higher Education. Research on Education and Media, 10(1), pp. 9-19.

Farivar, A., \& Rahimi, A. (2015). The Impact of CALL on Iranian EFL Learners' Autonomy. Procedia - Social and Behavioral Sciences, 192, pp. 644-649.

Fibaek Bertel, T., \& Ling, R. (2014). "It's just not that exciting anymore": The changing centrality of SMS in the everyday lives of young Danes. New Media \& Society, 18(7), pp. 1293-1309.

Field, A., Miles, J., \& Field, Z. (2012). Discovering statistics using R. London, UK: SAGE Publications, Ltd.

Fisher, L., Evans, M., \& Esch, E. (2004). Computer-Mediated Communication: promoting learner autonomy and intercultural understanding at secondary level. The Language Learning Journal, 30(1), pp. 50-58. 
Flowerdew, L. (2016). A genre-inspired and lexico-grammatical approach for helping postgraduate students craft research grant proposals. English for Specific Purposes, 42, pp. 1-12.

Fogal, G. G., Graham, F. H., \& Lavigne, A. G. (2014). Blended Learning: An Evolving Praxis. TESOL Journal, 5(2), pp. 363-373.

Fu, J. S. (2013). ICT in Education: A Critical Literature Review and Its Implications. International Journal of Education and Development using Information and Communication Technology (IJEDICT), 9(1), pp. 112-125.

Fučkan Držić, B. (2009). Učenje engleskoga kao jezika struke uz podršku programskog sustava za e-učenje. (Master's Thesis). Zagreb: Filozofski fakultet.

Fučkan Držić, B., Seljan, S., Mihaljević Djigunović, J., Lasić-Lazić, J., \& Stančić, H. (2011). Teaching English for Special Purposes Aided by E-learning Platform. International Journal of Excellence in e-Learning, 4(1), pp. 1-13.

Fuente, M. J. (2003). Is SLA Interactionist Theory Relevant to CALL? A Study on the Effects of Computer-Mediated Interaction in L2 Vocabulary Acquisition. Computer Assisted Language Learning, 16(1), pp. 47-81.

Fuertes-Olivera, P. A. (2018). ESP and Free Online Dictionaries. In R. Muñoz-Luna, \& L. Taillefer (Eds.), Integrating Information and Communication Technologies in English for Specific Purposes (pp. 127-143). Cham: Springer.

Galanek, J. D., Gierdowski, D. C., \& Brooks, D. C. (2018). ECAR Study of Undergraduate Students and Information Technology, 2018. Research report. Louisville, CO: ECAR.

Gallardo del Puerto, F., \& Gamboa, E. (2009). The evaluation of computer-mediated technology by second language teachers: collaboration and interaction in CALL. Educational Media International, 46(2), pp. 137-152.

García Alonso, J. L., \& Samy, D. (2018). Applicability of ICT-supported language teaching in contexts of social integration and international cooperation. Circulo de Linguistica Aplicada a la Comunicacion, 76, pp. 101-116.

Garcia, E. B. (2018). The classroom language context and English and Spanish vocabulary development among dual language learners attending Head Start. Early Childhood Research Quarterly, 42, pp. 148-157.

García-Sánchez, S. (2016). Ubiquitous interaction for ESP distance and blended learners. Journal of Applied Research in Higher Education, 8(4), pp. 489 - 503.

Gardner, D. (2007). Integrating self-access learning into an ESP course. In D. Gardner (Ed.), Learner autonomy 10: Integration and support (pp. 8-32). Dublin: Authentik. 
Gardner, D. (2011). Looking in and Looking Out: Managing a self-access centre. In D. Gardner (Ed.), Fostering autonomy in language learning (pp. 186-198). Gaziantep: Zirve University.

Gardner, R. C., \& Lambert, W. E. (1972). Attitudes and Motivation in Second-Language Learning. Rowley: Newbury House Publishers, Inc.

Garrett, N. (2009). Technology in the Service of Language Learning: Trends and Issues. The Modern Language Journal, 93, pp. 697-718.

Garrison, D. R. (2011). E-Learning in the 21st Century: A Framework for Research and Practice (Second edition). Routledge.

Garrison, D. R., \& Kanuka, H. (2004). Blended learning: Uncovering its transformative potential in higher education. Internet and Higher Education, 7, pp. 95-105.

Garrison, D. R., \& Vaughan, N. D. (2008). Blended Learning in Higher Education: Framework, Principles, and Guidelines. San Francisco, CA: Jossey-Bass.

Gass, S. M. (1993). Second language acquisition: past, present and future. Second Language Research, 9(2), pp. 99-117. https://doi.org/10.1177/026765839300900202

Gass, S. M. (2013). Second language acquisition: an introductory course (4th ed.). New York, London: Routledge.

Gass, S. M., \& Mackey, A. (2015). Input, Interaction and Output in Second Language Acquisition. In B. VanPatten, \& J. Williams (Eds.), Theories in Second Language Acquisition: An Introduction (pp. 180-206). New York, London: Routledge.

Gass, S. M., \& Varonis, E. M. (1994). Input, Interaction, and Second Language Production. Studies in Second Language Acquisition, 16(3), pp. 283-302.

Gass, S. M., Mackey, A., \& Pica, T. (1998). The Role of Input and Interaction in Second Language Acquisition: Introduction to the Special Issue. The Modern Language Journal, 82(3), pp. 299-305.

Gass, S., \& Mackey, A. (2006). Input, Interaction and Output: An Overview. AILA Review, 19, pp. 3-17.

Giesbers, B., Rienties, B., Tempelaar, D., \& Gijselaers, W. (2014). A dynamic analysis of the interplay between asynchronous and synchronous communication in online learning: The impact of motivation. Journal of Computer Assisted Learning, 30, pp. 30-50.

Gilmore, A. (2007). Authentic materials and authenticity in foreign language learning. Language Teaching, 40(2), pp. 97-118.

Godwin-Jones, R. (2011). Emerging Technologies: Mobile Apps for Language Learning. Language Learning \& Technology, 15(2), pp. 2-11. 
Goertler, S. (2009). Using Computer-Mediated Communication (CMC) in Language Teaching. Die Unterrichtspraxis/Teaching German, 42(1), pp. 74-84.

Golonka, E. M., Bowles, A. R., Frank, V. M., Richardson, D. L., \& Freynik, S. (2014). Technologies for foreign language learning: a review of technology types and their effectiveness. Computer Assisted Language Learning, 27(1), pp. 70-105.

Goundareva, I. (2011). Effect of translation practice on vocabulary acquisition in L2 Spanish. Working Papers of the Linguistics Circle, 21(1), pp. 145-154.

Grabar, I., \& Kolednjak, M. (2018). Značaj i vrijednost poučavanja stranih jezika i etike u području turizma. Conference proceedings of the 5th International Conference Innovation, Technology, Education and Management (pp. 61-66). Čakovec: MEV.

Graf, S., \& List, B. (2005). An evaluation of open source e-learning platforms stressing adaptation issues. ICALT 2005 - Proceedings of the 5th IEEE International Conference on Advanced Learning Technologies. Kaohsiung, Taiwan: 163-165.

Graham, C. R. (2006). Blended learning systems: Definition, current trends, and future directions. In C. J. Bonk, \& C. R. Graham (Eds.), Handbook of blended learning: Global perspectives, local designs (pp. 3-21). San Francisco, CA: Pfeiffer.

Graham, C. R. (2013). Emerging practice and research in blended learning. In M. G. Moore (Ed.), Handbook of distance education (3 ed., pp. 333-350). New York, NY: Routledge.

Graham, C. R., Allen, S., \& Ure, D. (2005). Benefits and challenges of blended learning environments. In Encyclopedia of information science and technology (pp. 253-259). Hershey, PA: Idea Group.

Gregg, K. R. (1984). Krashen's Monitor and Occam's Razar. Applied Linguistics, 5(2), pp. 79-100. doi: https://doi.org/10.1093/applin/5.2.79

Gremmo, M.-J., \& Riley, P. (1995). Autonomy, self-direction and self-access in language teaching and learning: The history of an idea. System, 23(2), pp. 151-164.

Guichon, N., \& Hauck, M. (2011). Editorial: Teacher education research in CALL and CMC: more in demand than ever. ReCALL, 23(3), pp. 187-199.

Gulbinskienè, D., Masoodi, M., \& Šliogerienè, J. (2017). Moodle as Virtual Learning Environment in Developing Language Skills, Fostering Metacognitive Awareness and Promoting Learner Autonomy. Pedagogika, 127(3), pp. 176-185. http://dx.doi.org/10.15823/p.2017.47

Gundu, N., \& Ozcan, D. (2017). Implementation of the Moodle System into EFL Classes. Profile: Issues in Teachers' Professional Development, 19(1), pp. 51-64. 
Haines, K. (2016). Expanding the knowledge base of teachers' use of communication tools for language learning. System, 62, pp. 102-112.

Halverson, L. R., Graham, C. R., Spring, K. J., Drysdale, J. S., \& Henrie, C. R. (2014). A thematic analysis of the most highly cited scholarship in the first decade of blended learning research. Internet and Higher Education, 20, pp. 20-34.

Hammond, M., Reynolds, L., \& Ingram, J. (2011). How and why do student teachers use ICT? Journal of Computer Assisted Learning, 27, pp. 191-203.

Hampel, R. (2009). Training teachers for the multimedia age: developing teacher expertise to enhance online learner interaction and collaboration. Innovation in Language Learning and Teaching, 3(1), pp. 35-50.

Hampel, R. (2014). Making meaning online: computer-mediated communication for language learning. In A. Peti-Stantić, \& M.-M. Stanojević (Ed.), Language as Information. Proceedings from the CALS Conference 2012 (pp. 89-106). Frankfurt am Main: Peter Lang.

Hampel, R., \& Pleines, C. (2013). Fostering Student Interaction and Engagement in a Virtual Learning Environment: An Investigation into Activity Design and Implementation. CALICO Journal, 30(3), pp. 342-370. doi:10.11139/cj.30.3.342-370

Hampel, R., \& Stickler, U. (2005). New skills for new classrooms: Training tutors to teach languages online. Computer Assisted Language Learning, 18(4), pp. 311-326.

Hampel, R., \& Stickler, U. (2015). Introduction: From Teacher Training to Self-Reflective Practice. In Developing Online Language Teaching: Research-Based Pedagogies and Reflective Practices (pp. 1-11). Hampshire: Palgrave Macmillan.

Han, Z., \& Tarone, E. (Eds.). (2014). Interlanguage: Forty Years Later. Amsterdam / Philadelphia: John Benjamins Publishing Company. https://doi.org/10.1075/11lt.39

Hans, A., \& Hans, E. (2015). A Comparative Study of English for Specific Purposes (ESP) and English as a Second Language (ESL) Programs. International Journal on Studies in English Language and Literature, 3(11), pp. 26-31.

Hassini, E. (2006). Student-instructor communication: The role of email. Computers \& Education, 47 , pp. 29-40.

Healey, D. (2002). Learner Autonomy with Technology: What do language learners need to be successful? TESOL 2002, CALL-IS Academic Session. Retrieved from http://www.deborahhealey.com/tesol2002/autonomy.html

Hemmi, A., Narumi-Munro, F., Alexander, W., Parker, H., \& Yamauch, Y. (2013). Co-evolution of mobile language learning: Going global with games consoles in higher education. British Journal of Educational Technology, 45(2), str. 356-366. doi:10.1111/bjet.12041 
Henderson, M., Selwyn, Neil, \& Aston, R. (2017). What works and why? Student perceptions of 'useful' digital technology in university teaching and learning. Studies in Higher Education, 42(8), pp. 1567-1579. https://doi.org/10.1080/03075079.2015.1007946

Hennessy, S., Ruthven, K., \& Brindley, S. (2005). Teacher perspectives on integrating ICT into subject teaching: commitment, constraints, caution, and change. Journal of Curriculum Studies, 37(2), pp. 155-192.

Hiltz, S. R., \& Turoff, M. (1994). The Network Nation: Human Communication via Computer. The MIT Press.

Hirschel, R. (2012). Moodle: Students' perspectives on forums, glossaries and quizzes. JALT CALL Journal, 8(2), pp. 95-112.

Holec, H. (1979). Autonomy and Foreign Language Learning. Council of Europe.

Horvat, A., Dobrota, M., Krsmanovic, M., \& Cudanov, M. (2015). Student perception of Moodle learning management system: a satisfaction and significance analysis. Interactive Learning Environments, 23(4), pp. 515-527.

Hosseini, S. B. (2015). Computer-Mediated Communication: Pedagogical and Language Learning Implications. International Journal on New Trends in Education and Their Implications, 6(1), pp. 163-176.

Hu, Z., \& McGrath, I. (2011). Innovation in higher education in China: are teachers ready to integrate ICT in English language teaching? Technology, Pedagogy and Education, 20(1), pp. 4159.

Huang, C.-J., Chen, H.-X., \& Chen, C.-H. (2009). Developing argumentation processing agents for computer-supported collaborative learning. Expert Systems with Applications, 36(2), pp. 26152624. Retrieved from https://doi.org/10.1016/j.eswa.2008.01.036

Huang, R., Kinshuk, \& Price, J. K. (Eds.). (2014). ICT in Education in Global Context: Emerging Trends Report 2013-2014. Springer.

Hubbard, P. (2009). A General Introduction to Computer Assisted Language Learning. In P. Hubbard (Ed.), Computer Assisted Language Learning: Critical Concepts in Linguistics. Volume I-Foundations of CALL (pp. 1-20).

Huckin, T., \& Coady, J. (1999). Incidental Vocabulary Acquisition in a Second Language: A Review. Studies in Second Language Acquisition, 21(2), pp. 181-193.

Hulstijn, J. H. (2007). Fundamental issues in the study of second language acquisition. EUROSLA Yearbook, 7, pp. 191-203. 
Hunt, A., \& Beglar, D. (2002). Current Research and Practice in Teaching Vocabulary. In J. C. Richards, \& W. A. Renandya (Eds.), Methodology in Language Teaching: An Anthology of Current Practice (pp. 258-266). Cambridge University Press.

Hutchinson, T., \& Waters, A. (1987). English for Specific Purposes: a learning-centred approach. Cambridge: Cambridge University Press.

Hyland, K. (2002). Specificity revisited: how far should we go now? English for Specific Purposes, 21, pp. 385-395.

Hyland, K. (2013). ESP and writing. In B. Paltridge, \& S. Starfield (Eds.), Handbook of English for Specific Purposes (pp. 95-114). Oxford: Blackwell.

Irwin, C., Ball, L., \& Desbrow, B. (2012). Students' perceptions of using Facebook as an interactive learning resource at university. Australasian Journal of Educational Technology, 28(7), pp. 12211232.

Jauregi, K., De Graaff, R., \& van den Bergh, H. (2012). Learning by doing: Promoting language teacher competencies for networked teaching and learning. Procedia - Social and Behavioral Sciences, 34, pp. $116-121$.

Jelovčić, I. (2010). English for specific purposes - student attitude analysis. Metodika, 20, pp. 124136.

Johns, A. M. (2013). The History of English for Specific Purposes Research. In B. Paltridge, \& S. Starfi (Eds.), The Handbook of English for Specific Purposes (pp. 5-30). John Wiley \& Sons, Inc.

Johnson, G. M. (2006). Synchronous and Asynchronous Text-Based CMC in Educational Contexts: A Review of Recent Research. TechTrends, 50(46), pp. 46-53.

Jones, M., \& McLean, K. (2018). ICT for Learning: Technology and Pedagogy. In Personalising Learning in Teacher Education (pp. 41-54). Singapore: Springer. https://doiorg.ezproxy.nsk.hr/10.1007/978-981-10-7930-6_4

Kadoić, N., \& Oreški, D. (2018). Analysis of Student Behavior and Success Based on Logs in Moodle. Proceedings of the 41st International Convention on Information and Communication Technology, Electronics and Microelectronics MIPRO 2018 (pp. 730-735). Opatija: MIPRO.

Kankaanranta, A., \& Louhiala-Salminen, L. (2017). ELF in the domain of business-BELF: what does the B stand for? In J. Jenkins, W. Baker, \& M. J. Dewey (Eds.), The Routledge Handbook of English as a Lingua Franca (pp. 309-320). Routledge.

Kanuka, H. (2011). Interaction and the online distance classroom: Do instructional methods effect the quality of interaction? Journal of Computing in Higher Education, 23, pp. 143-156. 
Karjalainen, K., Pörn, M., Rusk, F., \& Björkskog, L. (2013). Classroom tandem - Outlining a model instruction. International Electronic Journal of Elementary Education, 6(1), pp. 165-184.

Kavaliauskienë, G. (2009). Role of mother tongue in learning English for Specific Purposes. ESP World, 8(22).

Kavaliauskienë, G., \& Kaminskiene, L. (2007). Translation as a learning tool in English for specific purposes. Kalbotyra, 57(3), pp. 132-139.

Kawaguchi, S., \& Ma, Y. (2012). Corrective Feedback, Negotiation of Meaning and Grammar Development: Learner-Learner and Learner-Native Speaker Interaction in ESL. Open Journal of Modern Linguistics, 2(2), pp. 57-70.

Kember, D., Ho, A., \& Hong, C. (2008). The importance of establishing relevance in motivating student learning. Active Learning in Higher Education, 9(3), pp. 249-263.

Kenning, M.-M. (2001). Language learning interests at university. Language Learning Journal, 23(1), pp. 48-57.

Kenning, M.-M. (2010). Differences that make the difference: a study of functionalities in synchronous CMC. ReCALL, 22(1), pp. 3-19.

Khoii, R., \& Ashuri, S. (2016). Incidental Vocabulary Learning Through Information-Loaded and Negotiation-Oriented Tasks. International Journal of Applied Linguistics and English Literature (IJALEL), 5(7), pp. 30-39.

Kim, B., \& Park, M. J. (2018). Effect of personal factors to use ICTs on e-learning adoption: comparison between learner and instructor in developing countries. Information Technology for Development, 24(4), pp. 706-732.

Kirkwood, A. (2013). ICT in higher education: policy perspectives. ICT Leadership in Higher Education. Hyderabad, India.

Klasnić, K., Lasić-Lazić, J., \& Seljan, S. (2010). Quality Metrics of an Integrated E-Learning System - students' perspective. In S. Soomro (Ed.), E-learning experiences and future (pp. 71-93). Vienna: InTech.

Kordić, L., \& Mujić, N. (2003). Strani jezik u funkciji pravne struke: istraživanje stavova djelatnih pravnika i studenata prava. Pravni vjesnik, 19(3-4), pp. 57-78.

Kordić, L., \& Papa, D. (2014). Suradnja među katedrama u svrhu podizanja kvalitete nastave stranih jezika struke - komparativni pristup. Pravni vjesnik, 30(1), pp. 73-88.

Korljan, J., \& Škvorc, B. (2009). Elektronsko obrazovanje u nastavi hrvatskoga kao drugog i stranog jezika. Hrvatski, 7(2), pp. 9-29. Retrieved from https://hrcak.srce.hr/79865 
Kötter, M. (2003). Negotiation of meaning and codeswitching in online tandems. Language Learning \& Technology, 7(2), pp. 145-172. doi:10125/25203

Kovačić, A., Bubaš, G., \& Zlatović, M. (2007). Evaluation of activities with a wiki system in teaching English as a second language. Proceedings of the International Conference "ICT for Language Learning". Florence, Italy.

Kramsch, C., \& Thorne, S. L. (2002). Foreign language learning as global communicative practice. In D. Block, \& D. Cameron (Eds.), Globalization and Language Teaching (pp. 83-100). Routledge.

Krashen, S. D. (1979). A Response to McLaughlin, 'The Monitor Model: Some Methodological Considerations'. Language Learning, 29(1), pp. 151-168. https://doi.org/10.1111/j.14671770.1979.tb01056.x

Krashen, S. D. (1982). Principles and Practice in Second Language Acquisition. Pergamon Press Inc. Retrieved from http://www.sdkrashen.com/content/books/principles_and_practice.pdf

Krashen, S. D. (1998). Comprehensible output? System, 26, pp. 175-182.

Krasnova, T., \& Vanushin, I. (2016). Blended Learning Perception among Undergraduate Engineering Students. International Journal of Emerging Technologies in Learning (iJET), 11(1), pp. 54-56.

Kukulska-Hulme, A. (2010). Learning Cultures on the Move: Where are we heading? Educational Technology \& Society, 13(4), pp. 4-14.

Kukulska-Hulme, A., \& Shield, L. (2008). An overview of mobile assisted language learning: From content delivery to supported collaboration and interaction. ReCALL, 20(3), pp. 271-289.

Kumar, S., \& Tammelin, M. (2008). Integrating ICT into Language Learning and Teaching: Guide for Institutions. Linz: Johannes Kepler Universität Linz.

Kwak, D., Menezes, F. M., \& Sherwood, C. (2015). Assessing the Impact of Blended Learning on Student Performance. Economic Record, 91(292), pp. 91-106.

Lai, K.-W. (2008). ICT Supporting the Learning Process: The Premise, Reality, and Promise. In J. Voogt, \& G. Knezek (Eds.), International Handbook of Information Technology in Primary and Secondary Education Volume 20 (pp. 215-230). Boston, MA: Springer.

Lai, K.-W., \& Hong, K.-S. (2014). Technology use and learning characteristics of students in higher education: Do generational differences exist? British Journal of Educational Technology, 46(4), pp. 725-738. doi:10.1111/bjet.12161

Lam, Y. (2000). Technophilia vs. technophobia: A preliminary look at why second-language teachers do or do not use technology in their classrooms. Canadian Modern Language Review, 56(3), pp. 389-420. 
Lambić, D. (2016). Correlation between Facebook use for educational purposes and academic performance of students. Computers in Human Behavior, 61, pp. 313-320.

Lamy, M.-N., \& Hampel, R. (2007). Online Communication in Language Learning and Teaching. Palgrave Macmillan.

Lantolf, J. P. (2000). Second language learning as a mediated process. Language Teaching, 33(02), pp. 79-96.

Lantolf, J., \& Thorne, S. L. (2007). Sociocultural Theory and Second Language Learning. In B. VanPatten, \& J. Williams (Eds.), Theories in Second Language Acquisition (pp. 201-224). Mahwah, NJ: Lawrence Erlbaum.

Lantolf, J., Thorne, S. L., \& Poehner, M. (2015). Sociocultural Theory and Second Language Development. In B. VanPatten, \& J. Williams (Eds.), Theories in Second Language Acquisition (pp. 207-226). New York: Routledge.

Larsen-Freeman, D. (2018). Looking ahead: Future directions in, and future research into, second language acquisition. Foreign Language Annals, 51(1), pp. 55-72.

Larsen-Freeman, D., \& Long, M. H. (1991). An Introduction to Second Language Acquisition Research. London: Pearson Education Limited.

Larson, D. K., \& Sung, C.-H. (2009). Comparing Student Performance: Online Versus Blended Versus Face-to-Face. Journal of Asynchronous Learning Networks, 13(1), pp. 31-42.

Laufer, B., \& Hulstijn, J. (2001). Incidental vocabulary acquisition in a second language: the construct of task-induced involvement. Applied Linguistics, 22(1), pp. 1-26.

Laufer, B., \& Nation, P. (1999). A vocabulary size test of controlled productive ability. Language Testing, 16(1), pp. 33-51.

Lawrence, G. (2013). A working model for intercultural learning and engagement in collaborative online language learning environments. Intercultural Education, 24(4), pp. 303-314.

Lee, O., \& Im, Y. (2014). Innovation of Higher Education in the Globalized Era. In R. Huang, Kinshuk, \& J. K. Price (Eds.), ICT in Education in Global Context (pp. 221-247). Springer.

Lesiak-Bielawska, E. D. (2012). The Impact of Blended Learning on Teaching English for Vocational Purposes. Glottodidactica, 39, pp. 47-56.

Leuf, B., \& Cunningham, W. (2001). The Wiki way: quick collaboration on the Web. Boston: Addison-Wesley.

Levy, M. (1997). CALL: Context and Conceptualisation. Oxford: Oxford University Press. 
Light, D., \& Pierson, E. (2014). Case Studies of Russian Educators Transforming Classroom Practices Through ICT-Rich School Environments. In R. Huang, Kinshuk, \& J. K. Price (Eds.), ICT in Education in Global Context: Emerging Trends Report 2013-2014 (pp. 47-64). Springer.

Lim, D. H., Morris, M. L., \& Kupritz, V. W. (2007). Online vs. Blended Learning: Differences in Instructional Outcomes and Learner Satisfaction. Journal of Asynchronous Learning Networks, 11(2), pp. 27-42.

Lin, C.-H., Warschauer, M., \& Blake, R. (2016). Language learning through social networks: Perceptions and reality. Language Learning \& Technology, 20(1).

Lin, H. (2015). Computer-mediated communication (CMC) in L2 oral proficiency development: A meta-analysis. ReCALL, 27, pp. 261-287.

Lin, L.-F. (2010). A video-based CALL program for proficient and less-proficient L2 learners' comprehension ability, incidental vocabulary acquisition. Educational Media International, 47(3), pp. 199-216.

Little, D. (1991). Learner Autonomy 1: Definitions, Issues and. Dublin: Authentik Language Learning Resources.

Little, D. (2001). Learner autonomy and the challenge of tandem language learning via the Internet. In A. Chambers, \& G. Davies (Eds.), ICT and Language Learning: a European Perspective (pp. 29-38). Lisse: Swets and Zeitlinger Publishers b.v.

Little, D. (2003). Learner autonomy and second/foreign language learning. Retrieved from Subject Centre for Languages, Linguistics and Area Studies Good Practice Guide: https://www.llas.ac.uk/resources/gpg/1409

Littlejohn, A. (1997). Self-access work and curriculum ideologies. In P. Benson, \& P. Voller (Eds.), Autonomy and independence in Language Learning (pp. 181-191). Longman.

Littlewood, W. (1996). "Autonomy": An Anatomy and a Framework. System, 24(4), pp. 427-435.

Littlewood, W. (1997). Self-access: why do we want it and what can it do? In P. Benson, \& P. Voller (Eds.), Autonomy and Independence in Language Learning (pp. 79-91). London and New York: Routledge.

Liu, J. (2008). L1 Use in L2 Vocabulary Learning: Facilitator or Barrier. International Education Studies, 1(2), pp. 65-69.

Liu, M., Moore, Z., Graham, L., \& Lee, S. (2002). A Look at the Research on Computer-Based Technology Use in Second Language Learning. Journal of Research on Technology in Education, 34(3), pp. 250-273. 
Liuolienė, A., \& Metiūnienè, R. (2006). Second Language Learning Motivation. Santalka: Filologija, Edukologija, 14(2), pp. 93-98.

Livingstone, S. (2012). Critical reflections on the benefits of ICT in education. Oxford Review of Education, 38(1), pp. 9-24.

Loan, T. T. (2017). English performance and students' attitude towards ESP: A search for congruence. Asian Journal of Educational Research (AJER), 5(4), pp. 72-91.

Lonergan, J. (1994). Self-access language centres: implications for managers, teachers and learners. In E. Esch (Ed.), Self-Access and the Adult Language Learner (pp. 119-125). London: Centre for Information on Language Teaching and Research. Retrieved from https://files.eric.ed.gov/fulltext/ED382027.pdf

Long, M. H. (1981). Input, Interaction and Second Language Acquisition. Native Language and Foreign Language Acquisition, 379(1), pp. 259-278. https://doi.org/10.1111/j.17496632.1981.tb42014.x

Long, M. H. (1983). Linguistic and Conversational Adjustments to Non-Native Speakers. Studies in Second Language Acquisition, 5(2), pp. 177-193.

Long, M. H. (2003). Stabilization and Fossilization in Interlanguage Development. In C. J. Doughty, \& M. H. Long (Eds.), The Handbook of Second Language Acquisition (pp. 487-535).

Long, M. H. (2012). Current Trends in SLA Research and Directions for Future Development. Chinese Journal of Applied Linguistics, 35(2), pp. 135-152.

Lopes, A. P. (2011). Teaching with Moodle in higher education. INTED2011 Proceedings (pp. 970-976). Valencia, Spain: International Association of Technology, Education and Development (IATED).

Loucky, J. P. (2010). Constructing a roadmap to more systematic and successful online reading and vocabulary acquisition. Literary and Linguistic Computing, 25(2), pp. 225-241.

Luk, C.-H., Ng, K.-K., \& Lam, W.-M. (2018). he Acceptance of Using Open-Source Learning Platform (Moodle) for Learning in Hong Kong's Higher Education. In S. K. Cheung, J. Lam, K. C. Li, O. Au, W. W. Ma, \& W. S. Ho (Eds.), Technology in Education. Innovative Solutions and Practices. ICTE 2018. Communications in Computer and Information Science (Vol. 843, pp. 249257). Singapore: Springer.

Lund, A. (2008). Wikis: a collective approach to language production. ReCALL, 20(1), pp. 35-54.

Lungu, I. (2013). The Increasing Need for Blended-Learning Models in Courses of English for Specific Courses in Romanian Universities. Procedia - Social and Behavioral Sciences, 76, pp. 470-475. 
Luppicini, R. (2007). Review of computer mediated communication research for education. Instructional Science, 35, pp. 141-185.

Mackey, A. (1999). INPUT, INTERACTION, AND SECOND LANGUAGE DEVELOPMENT: An Empirical Study of Question Formation in ESL. Studies in Second Language Acquisition, 21(4), str. 557-587.

Madden, D. C. (2014). Inclusive Education in Rural Alberta, Canada: Utilizing ICT to Support Twenty-First Century Learning. In R. Huang, Kinshuk, \& J. K. Price (Eds.), ICT in Education in Global Context: Emerging Trends Report 2013-2014 (pp. 19-30). Springer.

Makin, L. (1994). Learner telesupport: language advising by e-mail. In E. Esch (Ed.), Self-Access and the Adult Language Learner (pp. 83-96). London: Centre for Information on Language Teaching and Research. Retrieved from https://files.eric.ed.gov/fulltext/ED382027.pdf

Martinović, A., \& Poljaković, I. (2010). Attitudes toward ESP among university students. Fluminensia, 22(2), pp. 145-161.

Matić, D., \& Matić-Bilić, M. (2008). English at Croatian universities: luxury or necessity. Maribor International Review, 1(1), pp. 43-55.

Mayer, R. E. (2009). Multimedia Learning (Second edition). Cambridge University Press.

McCombs, B. L., \& Vakili, D. (2005). A Learner-Centered Framework for E-Learning. Teachers College Record, 107(8), pp. 1582-1600.

McGraw, I., Yoshimoto, B., \& Seneff, S. (2009). Speech-enabled card games for incidental vocabulary acquisition in a foreign language. Speech Communication, 51(10), pp. 1006-1023.

McLaughlin, B. (1978). The Monitor Model: Some Methodological Considerations. Language Learning, 28(2), pp. 309-332. https://doi.org/10.1111/j.1467-1770.1978.tb00137.x

Means, B., Toyama, Y., Murphy, R., \& Baki, M. (2013). The effectiveness of online and blended learning: A meta-analysis of the empirical literature. Teachers College Record, 115, pp. 1-47.

Meara, P. (1980). Vocabulary Acquisition: A Neglected Aspect of Language Learning. Language Teaching, 13(3-4), pp. 221 - 246.

Medved Krajnović, M. (2010). Od jednojezičnosti do višejezičnosti:Uvod u istraživanja procesa ovladavanja inim jezikom. Zagreb: Leykam international d.o.o.

Meyers, E. M., Erickson, I., \& Small, R. V. (2013). Digital literacy and informal learning environments: an introduction. Learning, Media and Technology, 38(4), pp. 355-367.

Mihaljević Djigunović, J. (2010). Mirjana Vilke - plodna metodičarka engleskoga jezika. Metodika, 11(20), pp. 69-81. 
Mikulan, K., Legac, V., \& Oreški, P. (2017). Comparison of Croatian Foreign Language Teachers' General Propensity towards the Use of ICT and Its Impact on the Foreign Language Teaching Process. Athens Journal of Education, 4(1), pp. 39-62.

Mikulan, K., Legac, V., \& Siročić, D. (2011). Pozitivni i negativni aspekti platformi za učenje na daljinu Moodle i WebCT u nastavi hrvatskog jezika. Zbornik radova Međimurskog veleučilišta $u$ Čakovcu, 2(1), pp. 83-94.

Milton, J. (2013). Measuring the contribution of vocabulary. In C. Bardel, C. Lindqvist, \& B. Laufer (Eds.), L2 vocabulary acquisition, knowledge and use: new perspectives on assessment and corpus analysis (pp. 57-78). EUROSLA.

Mitchell, R., \& Myles, F. (2004). Second Language Learning Theories. London, UK: Hodder Arnold.

Miyazoe, T., \& Anderson, T. (2010). Learning outcomes and students' perceptions of online writing: Simultaneous implementation of a forum, blog, and wiki in an EFL blended learning setting. System, 38(2), pp. 185-199.

Monteiro, A., Leite, C., \& Lima, L. (2013). Quality of blended learning within the scope of the Bologna process. TOJET: The Turkish Online Journal of Educational Technology, 12(1), pp. 108118.

Moore, M. G. (1994). Editorial: Autonomy and interdependence. American Journal of Distance Education, 8(2), pp. 1-5. https://doi.org/10.1080/08923649409526851

Morrison, B. (2008). The role of the self-access centre in the tertiary language learning process. System, 36(2), pp. 123-140.

Motteram, G. (2013). Developing and extending our understanding of language learning and technology. In G. Motteram (Ed.), Innovations in learning technologies for English language teaching (pp. 175-192). British Council.

Mullamaa, K. (2010). ICT in Language Learning - Benefits and Methodological Implications. International Education Studies, 3(1), pp. 38-44.

Mumtaz, S. (2000). Factors affecting teachers' use of information and communications technology: a review of the literature. Journal of Information Technology for Teacher Education, 9(3), pp. 319342.

Murase, F. (2015) Measuring Language Learner Autonomy: Problems and Possibilities. In Everhard C.J., Murphy L. (Eds.), Assessment and Autonomy in Language Learning (pp.35-63). Palgrave Macmillan, London. https://doi.org/10.1057/9781137414380_3 
Mutlu, A., \& Eröz-Tuğa, B. (2013). The Role of Computer-Assisted Language Learning (CALL) in Promoting Learner Autonomy. Eurasian Journal of Educational Research, 51, pp. 107-122.

Nation, I. S., \& Beglar, D. (2007). A vocabulary size test. The language teacher, 31(7), pp. 9-13.

Nation, P. (2001). Learning Vocabulary in Another Language. Cambridge University Press.

Nation, P. (2015). Principles Guiding Vocabulary Learning through Extensive Reading. Reading in a Foreign Language, 27(1), pp. 136-145.

Navickienè, V., Kavaliauskienė, D., \& Pevcevičiūtė, S. (2015). Aspects of ESP learning motivation in tertiary education. Tiltai, 71(2), pp. 97-108. http://dx.doi.org/10.15181/tbb.v71i2.1103

Neumeier, P. (2005). A closer look at blended learning - parameters for designing a blended learning environment for language teaching and learning. ReCALL, 17(2), pp. 163-178.

$\mathrm{Ng}$, W. (2012). Can we teach digital natives digital literacy? Computers \& Education, 59, pp. 1065-1078.

Nguyen, L. V. (2008). Computer mediated communication and foreign language education: Pedagogical features. International Journal of Instructional Technology and Distance Learning, 5(12), pp. 23-44.

Nicolson, M., Murphy, L., \& Southgate, M. (Eds.). (2011). Language Teaching in Blended Contexts. Edinburgh, U.K.: Dunedin Academic Press.

Norberg, A., Dziuban, C. D., \& Moskal, P. D. (2011). A time-based blended learning model. On the Horizon, 19(3), pp. 207-216.

Nunan, D. (1991). Language Teaching Methodology: A Textbookfor Teacher. Upper Saddle River, NJ: Prentice Hall.

Nunan, D. (1997). Designing and adapting materials to encourage learner autonomy. In P. Benson, \& P. Voller (Eds.), Autonomy and Independence in Language Learning (pp. 192-203). London and New York: Routledge.

O’Dowd, R. (2017). Online Intercultural Exchange and Language Education. In S. May, \& S. L. Thorne (Eds.), Language, Education and Technology (pp. 207-218). Springer.

Ochoa Alpala, C. A. (2014). Electronic Engineering students' interactions through forums in the virtual component of a blended learning course. Cuadernos de Lingüistica Hispánica, 23, pp. 121150.

O'Dowd, R. (2003). Understanding the "Other Side": Intercultural learning in a Spanish-English email exchange. Language Learning \& Technology, 7(2), pp. 118-144. 
O'Dowd, R. (Ed.). (2007). Online Intercultural Exchange: An Introduction for Foreign Language Teachers. Multilingual Matters Ltd.

Okamoto, T., Anma, F., \& Nagata, N. (2014). The Framework for e-Learning 2.5 and Its Primary Functions. In R. Huang, Kinshuk, \& J. K. Price (Eds.), ICT in Education in Global Context: Emerging Trends Report 2013-2014 (pp. 249-262).

Oliver, M., \& Trigwell, K. (2005). Can 'Blended Learning' Be Redeemed? E-Learning, 2(1), pp. 17-26.

Oliver, R. (2005). Using blended learning approaches to enhance teaching and learning outcomes in higher education. Proceedings of the International Association of University Presidents' Teaching Showcase. Joondalup, WA: Edith Cowan University.

Oliver, R., \& Herrington, J. (2001). Teaching and learning online: a beginner's guide to e-learning and e-teaching in higher education. Mount Lawley, Australia: Centre for Research in Information Technology and Communications, Edith Cowan University.

Orsini-Jones, M., Pibworth-Dolinski, L., Cribb, M., Brick, B., Gazeley-Eke, Z., Leinster, H., \& Lloyd, E. (2015). Learning about language learning on a MOOC: how Massive, Open, Online and "Course"? In F. Helm, L. Bradley, M. Guarda, \& S. Thouësny (Ed.), Critical CALL - Proceedings of the 2015 EUROCALL Conference, Padova, Italy (pp. 450-457). Dublin: Researchpublishing.net. http://dx.doi.org/10.14705/rpnet.2015.000374

Ortega, L. (2009). Understanding Second Language Acquisition. London: Hodder Education.

Ortega, L. (2011). Second Language Acquisition. In J. Simpson (Ed.), The Routledge Handbook of Applied Linguistics (pp. 171-184). London: Routledge.

Oxford, R. L. (2003). Toward a More Systematic Model of L2 Learner Autonomy. In D. Palfreyman, \& R. C. Smith (Eds.), Learner Autonomy across Cultures (pp. 75-91). London: Palgrave Macmillan.

Pakzadian, M. (2012). The Effect of L1 on Learning New L2 Vocabulary among Intermediate Proficiency Level Students. Theory and Practice in Language Studies, 2(6), pp. 1147-1152.

Palak, D., \& Walls, R. T. (2009). Teachers' Beliefs and Technology Practices. Journal of Research on Technology in Education, 41(4), pp. 417-441.

Papadima-Sophocleous. (2012). CALL (computer assisted language learning) wiki. ProcediaSocial and Behavioral Sciences, 34, pp. 174-180.

Pavičić Takač, V. (2008). Vocabulary Learning Strategies and Foreign Language Acquisition. Clevedon: Multilingual Matters Ltd. 
Payne, M. (2011). Exploring Stephen Krashen's ' $i+1$ ' acquisition model in the classroom. Linguistics and Education, 22, pp. 419-429.

Peeters, W. (2015). Tapping into the Educational Potential of Facebook: Encouraging Out-of-Class Peer Collaboration in Foreign Language Learning. Studies in Self-Access Learning Journal, 6(2), pp. 176-190.

Pellicer-Sánchez, A. (2016). Incidental L2 vocabulary acquisition from and while reading. Studies in Second Language Acquisition, 38(01), pp. 97-130.

Penner, N., \& Grodek, E. (2014). Integrating Multimedia ICT Software in Language Curriculum: Students' Perception, Use, and Effectiveness. The EUROCALL Review, 22(1), pp. 20-39.

Pennycook, A. (1997). Cultural alternatives and autonomy. In P. Benson, \& P. Voller (Eds.), Autonomy and Independence in Language Learning (pp. 35-53). London: Longman.

Peters, E., \& Webb, S. (2018). Incidental Vocabulary Acquisition through Viewing L2 Television. Studies in Second Language Acquisition, 40(3), pp. 551-577.

Peterson, M. (2009). Learner interaction in synchronous CMC: a sociocultural perspective. Computer Assisted Language Learning, 22(4), pp. 303-321.

Peterson, M. (2010). Computerized Games and Simulations in Computer-Assisted Language Learning: A Meta-Analysis of Research. Simulation \& Gaming, 41(1), str. 72-93.

Peterson, M. (2012). Learner interaction in a massively multiplayer online role playing game (MMORPG): A sociocultural discourse analysis. ReCALL, 24(3), pp. 361-380.

Pietikäinen, K. S. (2017). ELF in social contexts. In J. Jenkins, W. Baker, \& M. J. Dewey (Eds.), The Routledge Handbook of English as a Lingua Franca (pp. 321-332). Routledge.

Plump, C. M., \& LaRosa, J. (2017). Using Kahoot! in the Classroom to Create Engagement and Active Learning: A Game-Based Technology Solution for eLearning Novices. Management Teaching Review, 2(3), pp. 151-158. https://doi.org/10.1177/2379298116689783

Polio, C., \& Gass, S. M. (1998). The Role of Interaction in Native Speaker Comprehension of Nonnative Speaker Speech. The Modern Language Journal, 82(3), pp. 308-319.

Porter, W. W., Graham, C. R., Spring, K. A., \& Welch, K. R. (2014). Blended learning in higher education: Institutional adoption and implementation. Computers \& Education, 75, pp. 185-195.

Puka, L. (2011). Kendall's Tau. In M. Lovrić (Ed.), International Encyclopedia of Statistical Science (pp. 713-715). Berlin-Heidelberg: Springer Verlag.

Rahman, M. (2015). English for Specific Purposes (ESP): A Holistic Review. Universal Journal of Educational Research, 3(1), pp. 24-31. 
Rahman, N. A., Hussein, N., \& Aluwi, A. H. (2015). Satisfaction on Blended Learning in a Public Higher Education Institution: What Factors Matter? Procedia - Social and Behavioral Sciences, 211, pp. 768-775.

Rama, P. S., Black, R. W., van Es, E., \& Warschauer, M. (2012). Affordances for second language learning in World of Warcraft. ReCALL, 24(3), pp. 322-338.

Ratz, S. (2016). Vocabulary Learning with the Moodle Glossary Tool: A Case Study. Journal of Perspectives in Applied Academic Practice, 4(1), pp. 44-51.

Raya, M. J., \& Vieira, F. (2015). Enhancing autonomy in language education: A case-based approach to teacher and learner development. Berlin/Boston: de Gruyter.

Reinhardt, J. (2017). Social Networking Sites and Language Education. In S. May, \& S. L. Thorne (Eds.), Language, Education and Technology (pp. 389-400).

Restrepo Ramos, F. D. (2015). Incidental vocabulary learning in second language acquisition: A literature review. PROFILE Issues in Teachers' Professional Development, 17(1), pp. 157-166.

Robinson, P. C. (1991). Esp Today: A Practitioner's Guide. New York: Prentice Hall International.

Ruiz-Molina, M.-E., Marín-García, A., \& Llopis-Amorós, M.-P. (2018). Moodle: the more you use it, the more you love it? Evidence about perceived usefulness of Moodle from international business students. In Pixel (Ed.), Conference Proceedings. The Future of Education. 8th Edition (pp. 99-103). Florence: Webster srl.

Şahin-Kız1l, A. (2014). Blended instruction for EFL learners: Engagement, learning and satisfaction. The JALT CALL Journal 2014: Forum, 10(3), pp. 175-188.

Salaberry, M. R. (2001). The use of technology for second language learning and teaching: A retrospective. The modern language journal, 85, pp. 39-56.

Salehi, H., \& Salehi, Z. (2012). Integration of ICT in language teaching: Challenges and barriers. 3rd International Conference on e-Education, e-Business, e-Management and e-Learning IPEDR vol. 27 (pp. 215-219). Singapore: IACSIT Press.

Sanders, R. H. (1994). Thirty Years of Computer Assisted Language Instruction: Introduction. CALICO Journal, 12(4), pp. 6-14.

Sangiamchit, C. (2017). ELF in electronically mediated intercultural communication. In J. Jenkins, W. Baker, \& M. J. Dewey (Eds.), The Routledge Handbook of English as a Lingua Franca (pp. 345-356). Routledge.

Sarieva, I., \& Zoran, A. (2007). Guiding Principles: Second Language Acquisition, Instructional Technology \& Constructivist Framework. In T. Erben, \& I. Sarieva (Eds.), CALLing all Foreign 
Language Teachers: Computer Assisted Languagelearning in the Classroom (pp. 7-12). Eye on Education, NY.

Schmenk, B. (2005). Globalizing Learner Autonomy. TESOL Quarterly, 39(1), pp. 107-118.

Schmitt, N. (2000). Vocabulary in language teaching. Cambridge: Cambridge University Press.

Schmitt, N. (2008). Review article: Instructed second language vocabulary learning. Language Teaching Research, 12(3), pp. 329-363.

Schmitt, N. (2010). Researching Vocabulary: A Vocabulary Research Manual. Basingstoke, UK: Palgrave Macmillan.

Schmitt, N., Schmitt, D. S., \& Clapham, C. (2001). Developing and exploring the behaviour of two new versions of the Vocabulary Levels Test. Language Testing, 18(1), pp. 55-88.

Schwienhorst, K. (2009). The art of improvisation: Learner autonomy, the learner, and (computerassisted) learning environments. In F. Kjisik, P. Voller, N. Aoki, \& Y. Nakata (Eds.), Mapping the terrain of learner autonomy: learning environments, learning communities and identities (pp. 86117). Tampere University Press.

Scrimshaw, P. (2004). Enabling teachers to make successful use of ICT. British Educational Communications and Technology Agency (BECTA).

Sefton-Green, J. (2004). Literature Review in Informal Learning with Technology Outside School. A NESTA Futurelab Series - Report 7.

Seidlhofer, B. (2005, October). Key concepts: English as a lingua franca. ELT Journal, 59(4), pp. 339-341.

Selinker, L. (1972). Interlanguage. International Review of Applied Linguistics, 10(3), pp. 209231.

Seljan, S. (2019). Informacijska i komunikacijska tehnologija (IKT) u interdisciplinarnom okruženju nastave jezika. In Y. Vrhovac, V. Berlengi Kapučin, R. Geld, A. B. Jelić, S. Letica Krevelj, S. Mardečić, \& M. Lütze-Miculinić (Eds.), Izazovi učenja stranoga jezika u osnovnoj školi (pp. 446-461). Zagreb: Ljevak, 2019.

Seljan, S., Banek, M., Špiranec, S., \& Lasić-Lazić, J. (2006). CALL (Computer-Assisted Language Learning) and Distance Learning. Proceedings of the 29th International Convention MIPRO 2006 (pp. 145-151). Rijeka: Hrvatska udruga za informacijsku i komunikacijsku tehnologiju.

Sharma, P. (2010). Blended learning. ELT Journal, 64(4), pp. 456-458. doi:10.1093/elt/ccq043

Sharma, P., \& Barrett, B. (2007). Blended Learning: Using Technology in and Beyond the Language Classroom. Oxford: Macmillan. 
Sharwood Smith, M. (1994). Second Language Learning: Theoretical Foundations. Taylor \& Francis.

Sheerin, S. (1997). An exploration of the relationship between self-access and independent learning. In P. Benson, \& P. Voller (Eds.), Autonomy and Independence in Language Learning (pp. 54-65). London and New York: Routledge.

Siemens, G., Gašević, D., \& Dawson, S. (2015). Preparing for the Digital University: a review of the history and current state of distance, blended, and online learning. Arlington: Link Research Lab.

Smith, R. (2008). Learner autonomy. ELT Journal Volume, 62(4), pp. 395-397.

Sobočan, M., \& Miščančuk, M. (2017). Analiza potrebe uvođenja dodatnih kolegija stranih jezika na preddiplomskom studiju Menadžment turizma i sporta Međimurskog veleučilišta u Čakovcu. Zbornik radova Međimurskog veleučilišta u Čakovcu, 8(2), pp. 83-87.

Southgate, M., \& Murphy, L. (2011). The nature of the 'blend': interaction of teaching modes, tools and resources. In M. Nicolson, L. Murphy, \& M. Southgate (Eds.), Language Teaching in Blended Contexts (pp. 13-27). Edinburgh, Scotland: Dunedin Academic Press Ltd.

Spanjers, I., Könings, K., Leppink, J., Verstegen, D., de Jong, N., Czabanowska, K., \& van Merriënboer, J. (2015). The promised land of blended learning: Quizzes as a moderator. Educational Research Review, 15, pp. 59-74.

Spence, P., \& Liu, G.-Z. (2013). Engineering English and the high-tech industry: A case study of an English needs analysis of process integration engineers at a semiconductor manufacturing company in Taiwan. English for Specific Purposes, pp. 97-109.

Spitzberg, B. H. (2006). Preliminary development of a model and measure of computer-mediated communication (CMC) competence. Journal of Computer-Mediated Communication, 11(2), pp. 629-666.

Spitzberg, B. H. (2011). The Interactive Media Package for Assessment of Communication and Critical Thinking (IMPACCT(C): Testing a Programmatic Online Communication Competence Assessment System. Communication Education, 60(2), pp. 145-173.

Spring, K. J., \& Graham, C. R. (2017). Thematic patterns in international blended learning literature, research, practices, and terminology. Online Learning, 21(4), pp. 337-361.

Spring, M. K. (2012). Languages for Specific Purposes Curriculum in the Context of ChineseLanguage Flagship Programs. The Modern Language Journal, 96(s1), pp. 140-157.

Stanley, I. (2007). Creating a student-generated glossary in Moodle: How is it done and how effective is it? JALT CALL Journal, 3(1-2), pp. 116-131. 
Stickler, U., \& Hampel, R. (2010). CyberDeutsch: Language Production and User Preferences in a Moodle Virtual Learning Environment. CALICO Journal, 28(1), pp. 49-73.

Stickler, U., \& Hampel, R. (2015). Transforming teaching: new skills for online language learning spaces. In R. Hampel, \& U. Stickler (Eds.), Developing Online Language Teaching: ResearchBased Pedagogies and Reflective Practices (pp. 63-77). Houndmills: Palgrave Macmillan.

Stockwell, G. (2007). A review of technology choice for teaching language skills in the CALL literature. ReCALL, 19(2), pp. 105-120.

Sumtsova, O., Aikina, T., Bolsunovskaya, L., Phillips, C., Zubkova, O., \& Mitchell, P. (2018). Collaborative Learning at Engineering Universities: Benefits and Challenges. International Journal of Emerging Technologies in Learning (iJET), 13(1), pp. 160-177.

Sutherland, R., Armstrong, V., Barnes, S., Brawn, R., Breeze, N., Gall, M., John, P. (2004). Transforming teaching and learning: embedding ICT into everyday classroom practices. Journal of Computer Assisted Learning 20, pp, 20, pp. 413-425.

Swain, M. (1995). Three functions of output in second language learning. In G. Cook, \& B. Seidlhofer (Eds.), Principle and Practice in Applied Linguistics: Studies in Honour of H. G. Widdowson (pp. 125-144). Oxford: Oxford University Press.

Swain, M. (1998). Manipulating and Complementing Content Teaching to Maximize Second Language Learning. TESL Canada Journal, 6(1), pp. 68-83.

Swain, M. (2000). The output hypothesis and beyond: Mediating acquisition through collaborative dialogue. In J. P. Lantolf (Ed.), Sociocultural Theory and Second Language Learning (pp. 97-114). Oxford: OUP.

Thang, S. M., Lee, K. W., Murugaiah, P., Jaafar, N. M., Tan, C. K., \& Bukhari, N. I. (2016). ICT Tools Patterns of Use among Malaysian ESL Undergraduates. GEMA Online ${ }^{\circledR}$ Journal of Language Studies, 16(1), pp. 49-65.

Thorne, K. (2003). Blended learning: how to integrate online and traditional learning. Kogan Page.

Thorne, S. L., \& Payne, J. S. (2005). Evolutionary Trajectories, Internet-mediated Expression, and Language Education. CALICO Journal, 22(3), pp. 371-397.

Thorne, S. L., Black, R. W., \& Sykes, J. M. (2009). Second Language Use, Socialization, and Learning in Internet Interest Communities and Online Gaming. The Modern Language Journal, 93, pp. 802-821.

Thorsteinsson, G., \& Niculescu, A. (2012). Examining Teachers' Mindset and Responsibilities in Using ICT. Studies in Informatics and Control, 22(3), pp. 315-322. 
Tosun, S. (2015). The effects of blended learning on EFL students' vocabulary. Procedia - Social and Behavioral Sciences, 199, pp. 641-647.

Trawiński, M. (2005). An outline of second language acquisition theories. Kraków: Wydawnictwo Naukowe Akademii Pedagogicznej.

Trebbi, T. (Ed.). (1990). Third Nordic Workshop on Developing Autonomous Learning in the FL Classroom, Bergen, August 11-14, 1989: Report. Bergen, Norway: Institutt for praktisk pedagogikk, Universitet i Bergen.

Tri, D. H., \& Nguyen, N. H. (2014). An Exploratory Study of ICT Use in English Language Learning Among EFL University Students. Teaching English with Technology, 4, pp. 32-46.

Trinder, R. (2017). Informal and deliberate learning with new technologies. ELT Journal, 71(4), pp. 401-412.

Truscott, J., \& Sharwood Smith, M. (2011). INPUT, INTAKE, AND CONSCIOUSNESS: The Quest for a Theoretical Foundation. Studies in Second Language Acquisition, 33(4), pp. 497- 528.

Tudini, V. (2003). Using native speakers in chat. Language Learning \& Technology, 7(3), pp. 141159.

Tzoannopoulou, M. (2015). Rethinking ESP: Integrating content and language in the university classroom. Procedia - Social and Behavioral Sciences, 173, pp. 149 - 153.

van Compernolle, R. A. (2017). Sociocultural Approaches to Technology Use in Language Education. In T. S., \& M. S. (Eds.), Language, Education and Technology. Encyclopedia of Language and Education (3rd ed.) (pp. 233-246). Cham: Springer.

van Lier, L. (1996). Interaction in the Language Curriculum: Awareness, Autonomy and Authenticity. Harlow, Essex: Pearson Education Limited.

VanDerLinden, K. (2014). Blended Learning as Transformational Institutional Learning. New Directions for Higher Education, 165, pp. 75-85.

VanPatten, B. (2018). Theories of Second Language Acquisition. In K. L. Geeslin (Ed.), The Cambridge Handbook of Spanish Linguistics (pp. 649-667). Cambridge University Press.

VanPatten, B., \& Williams, J. (2015). Theories in Second Language Acquisition. New York, London: Routledge.

Varonis, E. M., \& Gass, S. (1985). Non-native/Non-native Conversations: A Model for Negotiation of Meaning. Applied Linguistics, 6(1), pp. 71-90.

Veselá, K. (2012). Teaching ESP in New Environments. Nitra: ASPA. 
Vidal, K. (2011). A comparison of the effects of reading and listening on incidental vocabulary acquisition. Language Learning, 61(1), pp. 219-258.

Violić-Koprivec, A., \& Dubčić, J. (2010). Učenje stranih jezika na Sveučilištu u Dubrovniku u kontekstu suvremene Europe. MediAnali: međunarodni znanstveni časopis za pitanja medija, novinarstva, masovnog komuniciranja i odnosa s javnostima, 4(8), pp. 175-197.

Voogt, J., Knezek, G., Cox, M., Knezek, D., \& ten Brummelhuis, A. (2013). Under which conditions does ICT have a positive effect on teaching and learning? A Call to Action. Special Issue: Knowledge Transformation, Design and Technology, 29(1), pp. 4-14.

Vorderer, P., Krömer, N., \& Schneider, F. M. (2016). Permanently online - Permanently connected: Explorations into university students' use of social media and mobile smart devices. Computers in Human Behavior, 63, pp. 694-703.

Vromen, A., Xenos, M. A., \& Loader, B. (2015). Young people, social media and connective action: from organisational maintenance to everyday political talk. Journal of Youth Studies, 18(1), pp. 80-100.

Vurdien, R. (2017). Mobile Assisted Vocabulary Acquisition and Wikis to Enhance Writing Skills. International Journal of Computer-Assisted Language Learning and Teaching, 7(2), pp. 1-21. doi:10.4018/ijcallt.2017040101

Vygotsky, L. (1978). Mind in Society: The Development of Higher Psychological Processes. Cambridge, MA: Harvard University Press.

Vygotsky, L. (1986). Thought and language. Cambridge, MA: MIT Press.

Wach, A. (2012). Computer-Mediated Communication as an Autonomy-Enhancement Tool for Advanced Learners of English. Studies in Second Language Learning and Teaching, 2(3), pp. 367389.

Wang, J., Zou, B., Wang, D., \& Xing, M. (2013). Students' perception of a wiki platform and the impact of wiki engagement on intercultural communication. System, 41(2), pp. 245-256.

Wang, M.-T., \& Degol, J. L. (2017). Gender Gap in Science, Technology, Engineering, and Mathematics (STEM): Current Knowledge, Implications for Practice, Policy, and Future Directions. Educational Psychology Review, 29(1), pp. 119-140.

Warschauer, M. (1996). Computer Assisted Language Learning: An Introduction. In S. Fotos (Ed.), Multimedia language teaching (pp. 3-20). Tokyo: Logos International.

Warschauer, M. (2004). Technological change and the future of CALL. In S. Fotos, \& C. Brown (Eds.), New Perspectives on CALL for Second and Foreign Language Classrooms (pp. 15-25). Mahwah, NJ: Lawrence Erlbaum Associates. 
Warschauer, M. (2005). Sociocultural perspectives on CALL. In J. L. Egbert, \& G. M. Petrie (Eds.), CALL research perspectives (pp. 41-51). Mahwah, New Jersey: Lawrence Erlbaum Associates, Inc.

Warschauer, M. (2010). Invited Commentary: New Tools for Teaching Writing. Language Learning \& Technology, 14(1), pp. 3-8.

Warschauer, M., \& Healey, D. (1998). Computers and language learning: an overview. Language Teaching, 31, pp. 57-71.

Wastiau, P., Blamire, R., Kearney, C., Quittre, V., Van de Gaer, E., \& Monseur, C. (2013). The use of ICT in education: a survey of schools in Europe. European Journal of Education, 48(1), pp. $11-27$.

Watson, W. R., \& Watson, S. L. (2007). An Argument for Clarity: What are Learning Management Systems, What Are They Not, and What Should They Become? TechTrends, 51(2), pp. 28-34.

Watts, L. (2016). Synchronous and Asynchronous Communication in Distance Learning: A Review of the Literature. The Quarterly Review of Distance Education, 17(1), pp. 23-32.

Wertsch, J. (1991). Voices of the mind: A Sociocultural approach to mediated action. Cambridge, MA: Harvard University Press.

White, C. (2006). Distance learning of foreign languages. Language Teaching, 39(4), pp. 247-264.

White, L. (2003). Second Language Acquisition and Universal Grammar. Cambridge: Cambridge University Press.

Williams, D., Coles, L., Wilson, K., Richardson, A., \& Tuson, J. (2000). Teachers and ICT: current use and future needs. British journal of Educational Technology, 31(4), pp. 307-320.

Wold, K. (2013). Collaborative Inquiry: Expert Analysis of Blended Learning in Higher Education. International Journal on E-Learning, 12(2), pp. 221-238.

Woltering, V., Herrler, A., Spitzer, K., \& Spreckelsen, C. (2009). Blended learning positively affects students' satisfaction and the role of the tutor in the problem-based learning process: results of a mixed-method evaluation. Advances in Health Sciences Education, 14, pp. 725-738.

Wolz, U., Walker, H., Palme, J., Anderson, P., Chen, Z., Dunne, J., Spielvogel, R. (1997). Computer-mediated communication in collaborative educational settings (report of the ITiCSE ' 97 working group on CMC in collaborative educational settings). ITiCSE-WGR' 97 The supplemental proceedings of the conference on Integrating technology into computer science education: working group reports and supplemental proceedings (pp. 51-69). Uppsala, Sweden: ACM. 
$\mathrm{Xu}$, H., \& Mahenthiran, S. (2016). Factors that Influence Online Learning Assessment and Satisfaction: Using Moodle as a Learning Management System. International Business Research, 9(2), pp. 1-18. doi:10.5539/ibr.v9n2p1

Xu, L. (2012). The Application of Learner Autonomy Theory and Model into ESP Technologyassisted Curriculum Construction. International Journal of English Linguistics, 2(5), pp. 94-100.

Yen, Y.-C., Hou, H.-T., \& Chang, K. E. (2015). Applying role-playing strategy to enhance learners' writing and speaking skills in EFL courses using Facebook and Skype as learning tools: a case study in Taiwan. Computer Assisted Language Learning, 28(5), pp. 383-406.

Yeou, M. (2016). An Investigation of Students Acceptance of Moodle in a Blended Learning Setting Using Technology Acceptance Model. Journal of Educational Technology Systems, 44(3), pp. 300-318. Retrieved from https://doi.org/10.1177\%2F0047239515618464

Yunus, M. M., Lubis, M. A., \& Lin, C. P. (2009). Language learning via ICT: uses, challenges and issues. WSEAS Transactions on Information Science and Applications, 6(9), pp. 1453-1467.

Zhao, Y. (2003). Recent Developments in Technology and Language Learning: A Literature Review and Meta-analysis. CALICO Journal, 21(1), pp. 7-27.

Ziegler, N. (2016). Synchronous and Asynchronous Communication in Distance Learning: A Meta-Analysis. Studies in Second Language Acquisition, 38, pp. 553 - 586.

Zimmerman, C. B. (1996). Historical trends in second language vocabulary instruction. In J. Coady, \& T. Huckin (Eds.), Second Language Vocabulary Acquisition: A Rationale for Pedagogy

(pp. 5-19). Cambridge: Cambridge University Press. doi:10.1017/CBO9781139524643.003 


\section{APPENDIX}

\section{APPENDIX A: An example question from the 'Check your Level' test}

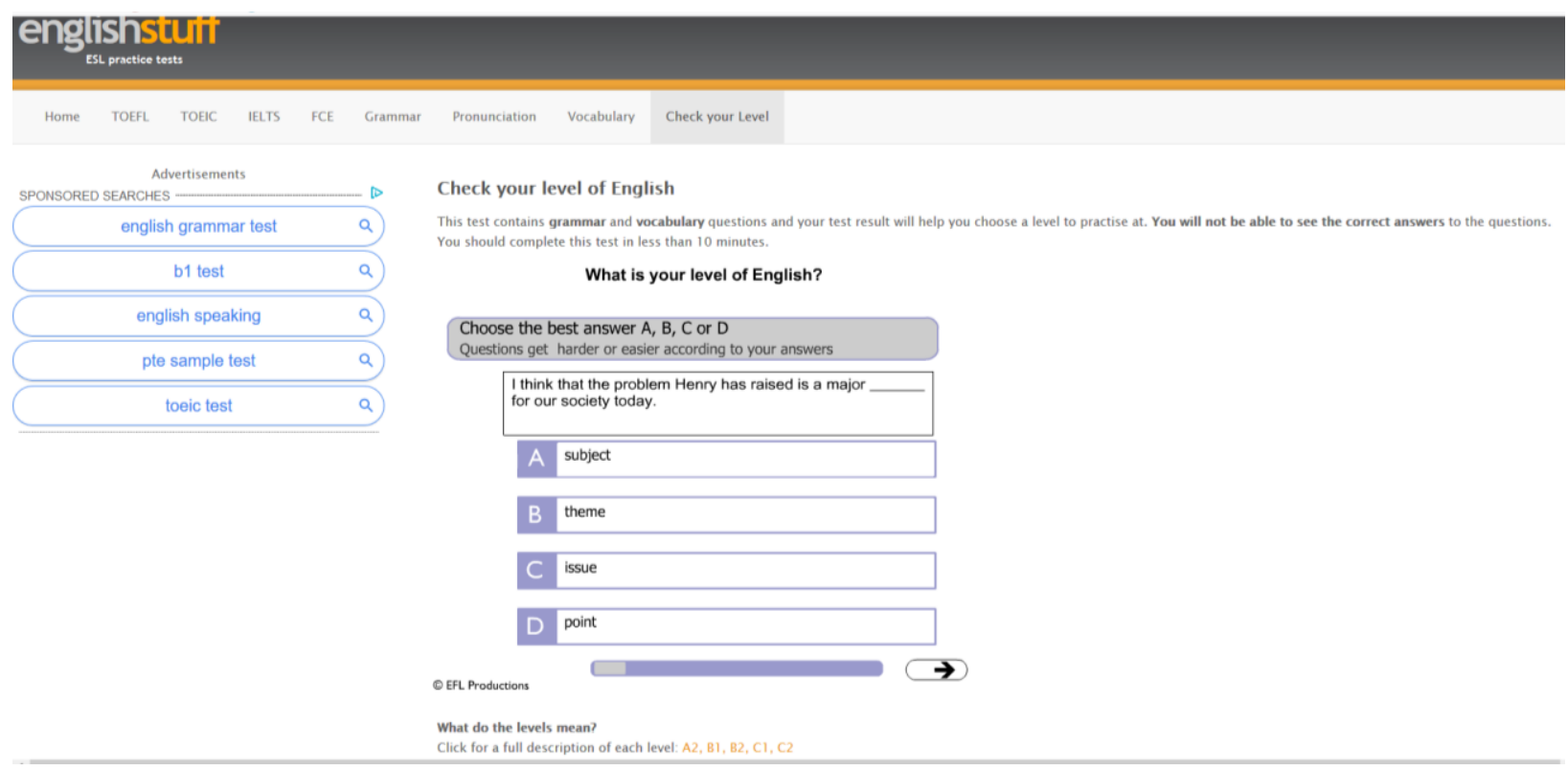


APPENDIX B: A result of the 'Check your Level' test

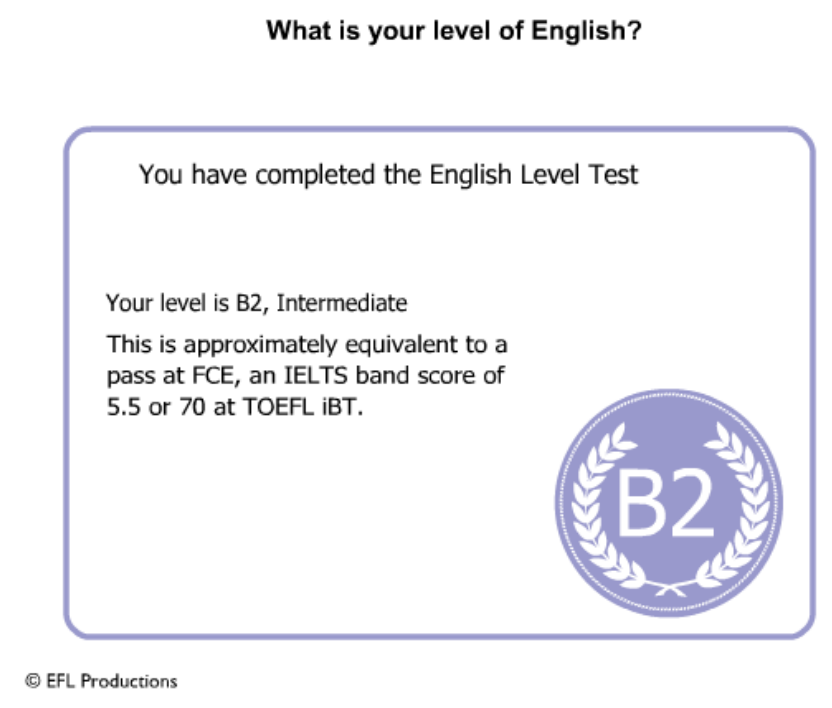


APPENDIX C: Vocabulary Test - 1000 Level Test A

\begin{tabular}{|c|c|c|c|}
\hline 1 & $\begin{array}{l}\text { We cut time into minutes, hours, and days. } \\
\text { a } \mathrm{T} \text { (This is True) } \\
\text { b N (This is Not true) } \\
\text { c X (I do Not understand the question) }\end{array}$ & 2 & $\begin{array}{l}\text { This one is little. } \\
\text { a } T \\
\text { b } N \\
\text { c } \quad X\end{array}$ \\
\hline 3 & 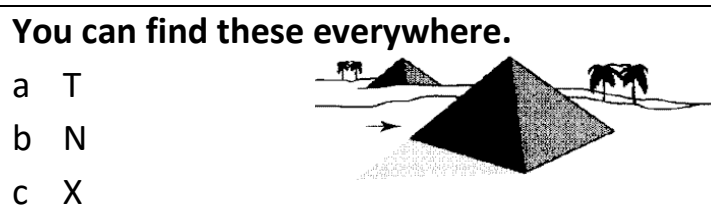 & 4 & $\begin{array}{l}\text { Some children call their mother Mama. } \\
\text { a } \quad T \\
\text { b } \\
\text { c } \\
\text { X }\end{array}$ \\
\hline . & $\begin{array}{l}\text { Show me the way to do it means 'show me } \\
\text { how to do it.' } \\
\text { a T } \\
\text { b N } \\
\text { c X }\end{array}$ & 6 & $\begin{array}{l}\text { This country is part of the world. } \\
\begin{array}{ll}\text { a } & T \\
\text { b } & N \\
\text { c } & X\end{array}\end{array}$ \\
\hline . & $\begin{array}{l}\text { This can keep people away from your } \\
\text { house. } \\
\text { a } \mathrm{T} \\
\mathrm{b} \quad \mathrm{N} \\
\mathrm{c} \quad \mathrm{X}\end{array}$ & 8 & $\begin{array}{l}\text { When something falls, it goes up. } \\
\text { a } \quad T \\
\text { b } \\
\text { c } \\
\text { c }\end{array}$ \\
\hline 9 & 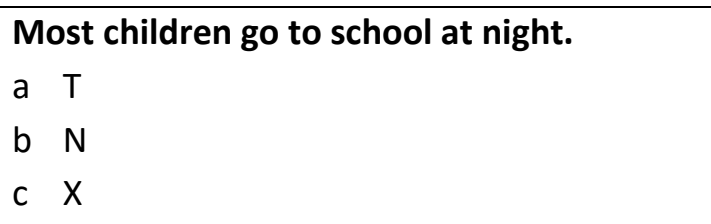 & 10 & 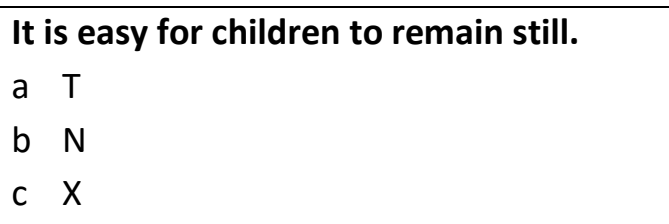 \\
\hline 11 & 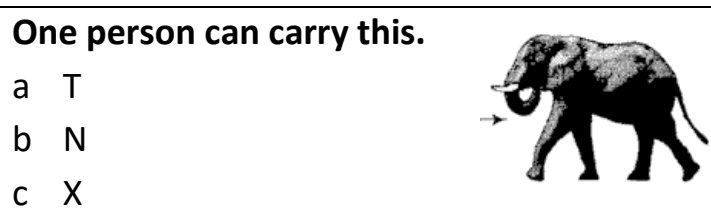 & 12 & 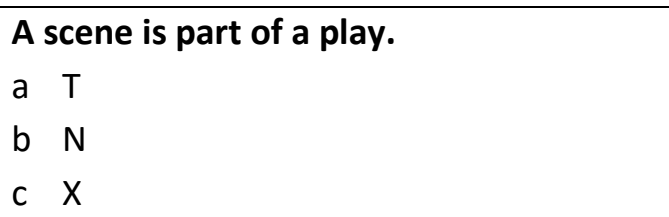 \\
\hline 13 & $\begin{array}{l}\text { People often think of their home, when } \\
\text { they are away from it. } \\
\text { a } \mathrm{T} \\
\text { b } \mathrm{N} \\
\text { c } \mathrm{X}\end{array}$ & 14 & 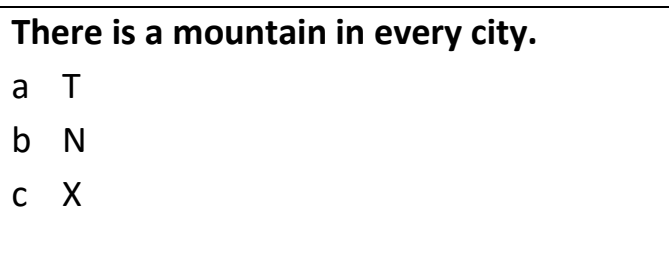 \\
\hline 15 & 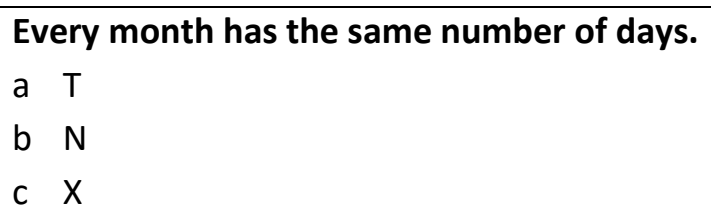 & 16 & 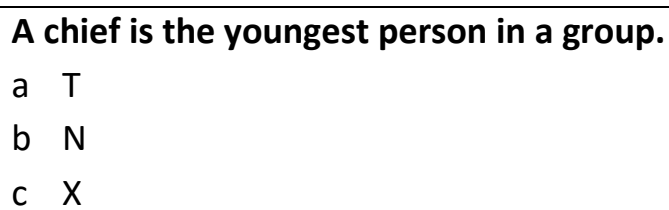 \\
\hline
\end{tabular}




\begin{tabular}{|c|c|c|}
\hline & $\begin{array}{l}\text { Black is a colour. } \\
\text { a } \mathrm{T} \\
\text { b } \mathrm{N} \\
\text { c } \mathrm{X}\end{array}$ & 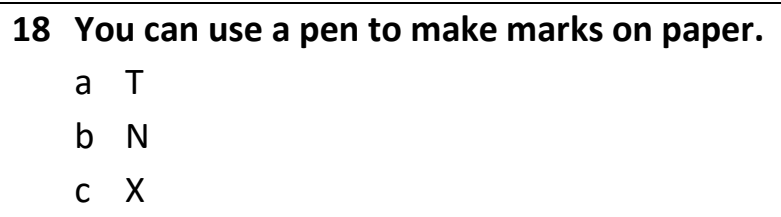 \\
\hline & 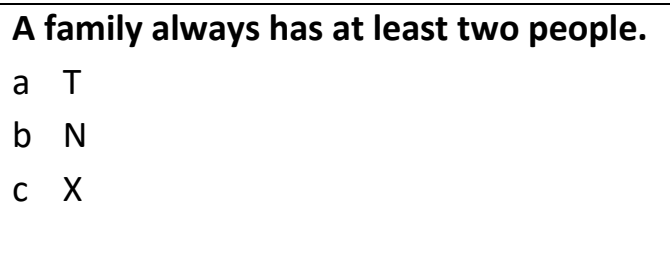 & $\begin{array}{l}20 \text { You can go by road from London to New } \\
\text { York. } \\
\text { a } \text { T } \\
\text { b } ~ N \\
\text { c } \quad X\end{array}$ \\
\hline 21 & 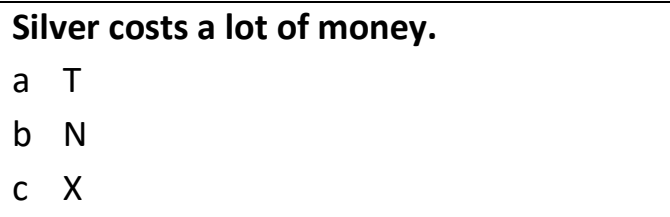 & $\begin{array}{l}22 \text { This is a hill. } \\
\text { a } \mathrm{T} \\
\text { b } \mathrm{N} \\
\text { c } \mathrm{X}\end{array}$ \\
\hline 23 & 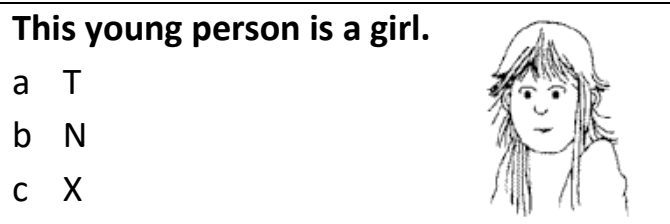 & $\begin{array}{l}24 \text { We can be sure that one day we will die. } \\
\text { a } \quad T \\
\text { b } ~ \\
\text { c } \\
\text { X }\end{array}$ \\
\hline 25 & $\begin{array}{l}\text { A society is made up of people living } \\
\text { together. } \\
\text { a } T \\
\text { b } N \\
\text { c } \mathrm{X}\end{array}$ & $\begin{array}{l}26 \text { An example can help you understand. } \\
\text { a } \mathrm{T} \\
\text { b } \mathrm{N} \\
\text { C } \mathrm{X}\end{array}$ \\
\hline 27 & 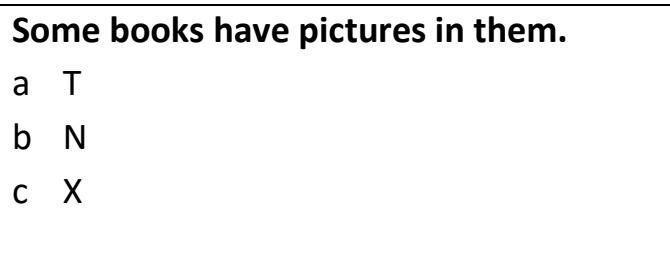 & $\begin{array}{l}28 \text { When some people attack other people, } \\
\text { they try to hurt them. } \\
\text { a T } \\
\text { b N } \\
\text { c X }\end{array}$ \\
\hline 29 & $\begin{array}{l}\text { When something is ancient, it is very big. } \\
\text { a } \quad T \\
\text { b } \\
\text { c N } \\
\text { c X }\end{array}$ & $\begin{array}{l}30 \text { Big ships can sail up a stream. } \\
\text { a } \quad T \\
\text { b } \\
\text { C } \\
\text { X }\end{array}$ \\
\hline 31 & $\begin{array}{l}\text { It is good to keep a promise. } \\
\begin{array}{ll}\text { a } & T \\
\text { b } & N \\
\text { c } & X\end{array}\end{array}$ & 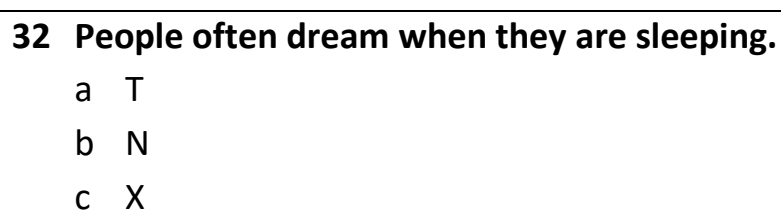 \\
\hline
\end{tabular}




\begin{tabular}{|l|l|}
\hline 33 This is a date - $\mathbf{1 0}$ o'clock. & 34 When something is impossible, it is easy to \\
a $T$ & do it. \\
b N & a \\
c X & b N \\
& 36 A square has five sides. \\
35 Milk is blue. & a T \\
a T & b N \\
b N & c X \\
c X & 38 Cars cannot pass each other on a wide road. \\
\hline 37 Boats are made to travel on land. & a T \\
a T & b N \\
b N & c X \\
c X & 40 This part is a handle. \\
\hline 39 When you look at something closely, you & a T \\
can see the details. & b N \\
a T & c X \\
b N & \\
c X &
\end{tabular}




\section{APPENDIX D1: Vocabulary test (Electrical Engineering)}

\section{Read the sentences and fill in the gaps using the appropriate word.}

1 Energy due to the position of the body is called energy.

2 Energy (e.g. noise) which is dissipated into the air and not used is called energy.

3 The ability to work well and produce good results by using the available time, money, supplies, etc. in the most effective way is called

4 The historic precursor to the modern electronics era was invented by Thomas Edison in 1880 while developing the electric lamp.

5 The adjustable (variable) resistor used in applications that require the adjustment of current or the varying of resistance in an electric circuit is called a

\section{Read the sentences and circle $T$ (true) or $F$ (false).}

\begin{tabular}{|c|c|c|c|}
\hline 1 & The speed, or rate, at which work is done is called power, and is measured in joules. & $\mathbf{T}$ & $\mathbf{F}$ \\
\hline 2 & $\begin{array}{l}\text { Electronics technology experienced a revolution in } 1948 \text { with the invention of the } \\
\text { Audion tube. }\end{array}$ & $\mathbf{T}$ & $\mathbf{F}$ \\
\hline 3 & Transistor technology is often referred to as solid-state electronics. & $\mathbf{T}$ & $\mathbf{F}$ \\
\hline 4 & $\begin{array}{l}\text { An electric locomotive is one that is powered by an internal energy source, most often } \\
\text { via overhead electric lines. }\end{array}$ & $\mathbf{T}$ & $\mathbf{F}$ \\
\hline 5 & $\begin{array}{l}\text { Electric locomotives use only electrical energy. This means there is no need to convert } \\
\text { energy from one form to another on board the train. }\end{array}$ & $\mathbf{T}$ & $\mathbf{F}$ \\
\hline 6 & If a machine converts a high percentage of energy into useful energy, it is not efficient. & $\mathbf{T}$ & $\mathbf{F}$ \\
\hline 7 & In a diesel-electric unit, the energy conversion process starts with thermal energy. & $\mathbf{T}$ & $\mathbf{F}$ \\
\hline 8 & Renewable energy resources are constantly replenished and will never run out. & $\mathbf{T}$ & $\mathbf{F}$ \\
\hline 9 & EMF stands for electromagnetic force. & $\mathbf{T}$ & $\mathbf{F}$ \\
\hline 10 & $\begin{array}{l}\text { The threshold marking the transition from electric to electronic is defined by how the } \\
\text { flow of electrons is controlled. }\end{array}$ & $\mathbf{T}$ & $\mathbf{F}$ \\
\hline
\end{tabular}

\section{Translate the words into English/Croatian.}

\begin{tabular}{|ll|l|ll|l|}
\hline & ENGLISH & CROATIAN & & CROATIAN & ENGLISH \\
\hline 1 & precursor (n.) & & 1 & strujni krug & \\
\hline 2 & switch (n.) & & 2 & izmjenična struja & \\
\hline 3 & convert (v.) & & 3 & raspršiti & \\
\hline 4 & conductive (adj.) & & 4 & poluvodič & \\
\hline 5 & filament (n.) & & 5 & izumiti & \\
\hline
\end{tabular}




\section{APPENDIX D2: Vocabulary test (Mechanical Engineering)}

\section{Read the sentences and fill in the gaps using the appropriate word.}

1 Gear wheels are wheels with teeth or

2 A stretching force is called

3 The ability of a material to absorb force and flex in different directions, returning to its original position is called

4 The action of two surfaces being rubbed together is called

5 A material or device that conducts or transmits heat or electricity, especially when regarded in terms of its capacity to do this is called a

\section{Read the sentences and circle $T$ (true) or $F$ (false).}

\begin{tabular}{|cl|c|c|}
\hline 1 & An assembly of several shafts and gear wheels is called a transmission train. & $\mathbf{T}$ & $\mathbf{F}$ \\
\hline 2 & Gears which provide a one-way drive are called spur gears. & $\mathbf{T}$ & $\mathbf{F}$ \\
\hline 3 & CVT stands for continually variable transmission. & $\mathbf{T}$ & $\mathbf{F}$ \\
\hline 4 & When a material is subjected to tension, its length will decrease by a certain amount. & $\mathbf{T}$ & $\mathbf{F}$ \\
\hline 5 & If a material has low elasticity and is weak, it is described as stiff. & $\mathbf{T}$ & $\mathbf{F}$ \\
\hline 6 & Scratch hardness describes a material's ability to resist being scratched. & $\mathbf{T}$ & $\mathbf{F}$ \\
\hline 7 & $\begin{array}{l}\text { The wheel's guards must be constructed from material with a high degree of indentation } \\
\text { hardness, to protect it from impacts. }\end{array}$ & $\mathbf{T}$ & $\mathbf{F}$ \\
\hline 8 & If a material yields it has been loaded beyond its ultimate tensile strength. & $\mathbf{T}$ & $\mathbf{F}$ \\
\hline 9 & A shaft connected directly to an engine or motor is called a follower. & $\mathbf{T}$ & $\mathbf{F}$ \\
\hline 10 & As temperature increases, most materials expand, and as temperature falls, they contract. & $\mathbf{T}$ & $\mathbf{F}$ \\
\hline
\end{tabular}

III. Translate the words into English/Croatian.

\begin{tabular}{|ll|l|r|l|}
\hline & ENGLISH & CROATIAN & CROATIAN & ENGLISH \\
\hline 1 & malleable (adj.) & & 1 izolator & \\
\hline 2 & conductivity (n.) & & 2 omjer & \\
\hline 3 & sprocket (n.) & & 3 sastavni dio & \\
\hline 4 & pulley (n.) & & 4 plastičnost & \\
\hline 5 & condense (v.) & & 5 ubrzanje & \\
\hline
\end{tabular}




\section{APPENDIX D3: Vocabulary test (Multimedia, Design and Application)}

\section{Read the sentences and fill in the gaps using the appropriate word.}

1 The protocol needed for online phone conversations is called

2 Newspapers are divided into tabloids and

3 An abstract illustrative organization of colour hues around a circle that shows relationships between primary colours, complementary colours, etc. is called a

4 A large thin book with a paper cover, containing reports, photographs, stories, etc., usually published once a month or once a week is called a

5 Groups of individuals who share a commonality are called

\section{Read the sentences and circle $T$ (true) or $F$ (false).}

\begin{tabular}{|cl|c|c|}
\hline 1 & IRC stands for International relay chat. & $\mathrm{T}$ & $\mathrm{F}$ \\
\hline 2 & Radio and television are referred to as broadcast media. & $\mathrm{T}$ & $\mathrm{F}$ \\
\hline 3 & Multimedia is a term that covers all means of mass information and communication. & $\mathrm{T}$ & $\mathrm{F}$ \\
\hline 4 & World Wide Web is the global system of IP networks. & $\mathrm{T}$ & $\mathrm{F}$ \\
\hline 5 & People sharing distinct personal traits often share colour perceptions and preferences. & $\mathrm{T}$ & $\mathrm{F}$ \\
\hline 6 & Internet is a short form of the technical term internetwork. & $\mathrm{T}$ & $\mathrm{F}$ \\
\hline 7 & $\begin{array}{l}\text { Online telephone conversations, either computer-to-computer or computer-to-phone, } \\
\text { require special software or an applet. }\end{array}$ & $\mathrm{T}$ & $\mathrm{F}$ \\
\hline 8 & Instant messaging programs allow Internet users to communicate in group conversations. & $\mathrm{T}$ & $\mathrm{F}$ \\
\hline 9 & Convergence is one of the key features of new media. & $\mathrm{T}$ & $\mathrm{F}$ \\
\hline 10 & Interactivity and convergence are synonymous. & $\mathrm{T}$ & $\mathrm{F}$ \\
\hline
\end{tabular}

\section{Translate the words into English/Croatian.}

\begin{tabular}{|ll|l|rl|l|}
\hline \multicolumn{1}{|c|}{ ENGLISH } & CROATIAN & \multicolumn{1}{c|}{ CROATIAN } & ENGLISH \\
\hline 1 & broadcast (v.) & & 1 koji ne razlikuje boje & \\
\hline 2 & access (n.) & & 2 učinak & \\
\hline 3 & broadband (adj.) & & 3 povratna informacija & \\
\hline 4 & evoke (n.) & & 4 razlikovati & \\
\hline 5 & layout (n.) & & 5 sudionik & \\
\hline
\end{tabular}




\section{APPENDIX D4: Vocabulary test (Technical and Economic Logistics)}

\section{Read the sentences and fill in the gaps using the appropriate word.}

1 A very important function that determines the health of the supply chain as well as impacts the financial health of the balance sheet is called

2 An amount or quantity of something that is available to use is called

3 The movement of people, animals and goods from one location to another is called

4 The transport used for large volumes of durable items is transport.

5 One of the common inventory-management strategies is the method, where companies plan to receive items as they are needed.

\section{Read the sentences and circle $T$ (true) or $F$ (false).}

\begin{tabular}{|c|c|c|c|}
\hline 1 & $\begin{array}{l}\text { Number of minutes, hours, or days that must be allowed for the completion of an } \\
\text { operation or process, or must elapse before a desired action takes place is called lead } \\
\text { time. }\end{array}$ & $\mathbf{T}$ & $\mathbf{F}$ \\
\hline 2 & Inventory is not dynamic. & $\mathbf{T}$ & $\mathbf{F}$ \\
\hline 3 & $\begin{array}{l}\text { A wholesaler is a business that buys products from manufacturers and resells them to the } \\
\text { ultimate consumer. }\end{array}$ & $\mathbf{T}$ & $\mathbf{F}$ \\
\hline 4 & Inventory planners continuously monitor, control and review inventory. & $\mathbf{T}$ & $\mathbf{F}$ \\
\hline 5 & Collecting and handling of used or damaged goods or equipment is called break-bulking. & $\mathbf{T}$ & $\mathbf{F}$ \\
\hline 6 & $\begin{array}{l}\text { The relationship between how much of a particular product is available and how much } \\
\text { of it people want, and especially the way that this affects the level of prices, is called } \\
\text { inventory. }\end{array}$ & $\mathbf{T}$ & $\mathbf{F}$ \\
\hline 7 & $\begin{array}{l}\text { Stake is the proportional part of a company's equity capital represented by fully paid up } \\
\text { shares. }\end{array}$ & $\mathbf{T}$ & $\mathbf{F}$ \\
\hline 8 & Defective products, defective parts and scrap do not form a part of inventory. & $\mathbf{T}$ & $\mathbf{F}$ \\
\hline 9 & $\begin{array}{l}\text { An arrangement in which a firm with long and varied supply chains outsources it } \\
\text { logistical operations to one or more specialist firms is called third party logistics. }\end{array}$ & $\mathbf{T}$ & $\mathbf{F}$ \\
\hline 10 & EPA stands for European Protection Agency. & $\mathbf{T}$ & $\mathbf{F}$ \\
\hline
\end{tabular}

\section{Translate the words into English/Croatian.}

\begin{tabular}{|ll|l|rl|l|}
\hline \multicolumn{1}{|c|}{ ENGLISH } & CROATIAN & \multicolumn{1}{c|}{ CROATIAN } & ENGLISH \\
\hline 1 & procurement (n.) & & 1 & isporuka & \\
\hline 2 & assets (n.) & & 2 & konkurencija & \\
\hline 3 & facilitate (v.) & & 3 & vozilo & \\
\hline 4 & overlapping (adj.) & & 4 & dobavljač & \\
\hline 5 & determine (v.) & & 5 & trgovac na malo & \\
\hline
\end{tabular}




\section{APPENDIX D5: Vocabulary test (Civil Engineering)}

\section{Read the sentences and fill in the gaps using the appropriate word.}

1 The term used for mixing concrete accurately is

2 A flexible cement impregnated fabric that hardens on hydration to form a thin, durable waterproof and fireproof concrete layer is called

3 Specification of concrete ingredients is called

4 The individual components that make up assemblies and structures can be connected in different ways. The place of connection is called a connection or

5 A suspension bridge has got two main cables which are supported by

\section{Read the sentences and circle $T$ (true) or F (false).}

\begin{tabular}{|c|c|c|c|}
\hline 1 & Gravel used in concrete is called fine aggregate. & $\mathbf{T}$ & $\mathbf{F}$ \\
\hline 2 & A steel bloom is a type of ingot. & $\mathbf{T}$ & $\mathbf{F}$ \\
\hline 3 & $\begin{array}{l}\text { When dealing with bridge foundations, grout is used to seal the joint against rainwater, } \\
\text { protecting the bolts from corrosion. }\end{array}$ & $\mathbf{T}$ & $\mathbf{F}$ \\
\hline 4 & Steel billets can be cut into smaller sized pieces called blooms. & $\mathbf{T}$ & $\mathbf{F}$ \\
\hline 5 & Retarder allows concrete to stay dry for longer. & $\mathbf{T}$ & $\mathbf{F}$ \\
\hline 6 & Urbanization aggravates floods. & $\mathbf{T}$ & $\mathbf{F}$ \\
\hline 7 & Pellets do not require further processing. & $\mathbf{T}$ & $\mathbf{F}$ \\
\hline 8 & $\begin{array}{l}\text { The cables of a suspension bridge are anchored at each end by huge blocks of concrete, } \\
\text { which are deeply embedded in the ground. }\end{array}$ & $\mathbf{T}$ & $\mathbf{F}$ \\
\hline 9 & $\begin{array}{l}\text { When foundations for steel columns are poured, triangle-shaped holes are formed in the } \\
\text { concrete to accommodate bolts to hold down the base plate. }\end{array}$ & $\mathbf{T}$ & $\mathbf{F}$ \\
\hline 10 & $\begin{array}{l}\text { Solid concrete construction whose mass counterbalances the weight of the suspended } \\
\text { roadway is called the approach ramp. }\end{array}$ & $\mathbf{T}$ & $\mathbf{F}$ \\
\hline
\end{tabular}

\section{Translate the words into English/Croatian.}

\begin{tabular}{|ll|l|ll|l|}
\hline & ENGLISH & CROATIAN & & CROATIAN & ENGLISH \\
\hline 1 & rectify (v.) & & 1 & kuglica, sačma & \\
\hline 2 & durable (adj.) & & 2 & kalup & \\
\hline 3 & plate (n.) & & 3 & šipka & \\
\hline 4 & gutter (n.) & 4 & istjecati; ispustiti & \\
\hline 5 & bolt (n.) & & 5 & održiv & \\
\hline
\end{tabular}




\section{APPENDIX E: ELP Checklist}

\section{LEVEL A1}

\section{Listening}

I can understand when someone speaks very slowly to me and articulates carefully, with long pauses for me to assimilate meaning.

I can understand simple directions about how to get from $X$ to $Y$, on foot or by public transport.

I can understand questions and instructions addressed carefully and slowly to me and follow short, simple directions.

I can understand numbers, prices and times.

\section{Reading}

I can understand information about people (place of residence, age etc.) in newspapers.

I can locate a concert or a film on calendars of public events or posters and identify where it takes place and at what time it starts.

I can understand a questionnaire (entry permit form, hotel registration form) well enough to give the most important information about myself (name, surname, date of birth, nationality).

I can understand words and phrases on signs encountered in everyday life (for instance

"station", "car park", "no parking", "no smoking", "keep left").

I can understand the most important orders in a computer programme such as "PRINT", "SAVE", "COPY" etc.

I can understand short simple messages on postcards, for example holiday greetings.

In everyday situations I can understand simple messages written by friends or colleagues, for example "back at 4 o'clock".

\section{Spoken Interaction}

I can introduce somebody and use basic greeting and leave-taking expressions.

I can ask and answer simple questions, initiate and respond to simple statements in areas of immediate need or on very familiar topics.

I can make myself understood in a simple way but I am dependent on my partner being prepared to repeat more slowly and rephrase what I say and to help me to say what I want.

I can make simple purchases where pointing or other gestures can support what I say.

I can handle numbers, quantities, cost and time.

I can ask people for things and give people things.

I can ask people questions about where they live, people they know, things they have etc. and answer such questions addressed to me provided they are articulated slowly and clearly.

I can indicate time by such phrases as "next week", "last Friday", "in November", "three o'clock".

\section{Spoken Production}

I can give personal information (address, telephone number, nationality, age, family, and hobbies).

I can describe where I live. 


\section{Strategies}

I can say when I don't understand.

I can very simply ask somebody to repeat what they said.

\section{Writing}

I can fill in a questionnaire with my personal details (job, age, address, hobbies).

I can write a greeting card, for instance a birthday card.

I can write a simple postcard (for example with holiday greetings).

I can write a note to tell somebody where I am or where we are to meet.

I can write sentences and simple phrases about myself, for example where I live and what I do.

\section{LEVELA2}

\section{Listening}

I can understand what is said clearly, slowly and directly to me in a simple everyday conversation; it is possible to make me understand, if the speaker can take the trouble.

I can generally identify the topic of discussion around me when people speak slowly and clearly. I can understand phrases, words and expressions related to areas of most immediate priority (e.g. very basic personal and family information, shopping, local area, employment).

I can catch the main point in short, clear, simple messages and announcements.

I can understand the essential information in short recorded passages dealing with predictable everyday matters which are spoken slowly and clearly.

I can identify the main point of TV news items reporting events, accidents etc. when the visual supports the commentary.

\section{Reading}

I can identify important information in news summaries or simple newspaper articles in which numbers and names play an important role and which are clearly structured and illustrated. I can understand a simple personal letter in which the writer tells or asks me about aspects of everyday life.

I can understand simple written messages from friends or colleagues, for example saying when we should meet to play football or asking me to be at work early.

I can find the most important information on leisure time activities, exhibitions etc. in information leaflets.

I can skim small advertisements in newspapers, locate the heading or column I want and identify the most important pieces of information (price and size of apartments, cars, computers).

I can understand simple user's instructions for equipment (for example, a public telephone). I can understand feedback messages or simple help indications in computer programmes. I can understand short narratives about everyday things dealing with topics which are familiar to me if the text is written in simple language.

\section{Spoken Interaction}


I can make simple transactions in shops, post offices or banks.

I can use public transport: buses, trains, and taxis, ask for basic information and buy tickets.

I can get simple information about travel.

I can order something to eat or drink.

I can make simple purchases by stating what I want and asking the price.

I can ask for and give directions referring to a map or plan.

I can ask how people are and react to news.

I can make and respond to invitations.

I can make and accept apologies.

I can say what I like and dislike.

I can discuss with other people what to do, where to go, and make arrangements to meet.

I can ask people questions about what they do at work and in free time, and answer such questions addressed to me.

\section{Spoken Production}

I can describe myself, my family and other people.

I can describe where I live.

I can give short, basic descriptions of events.

I can describe my educational background, my present or most recent job.

I can describe my hobbies and interests in a simple way.

I can describe past experiences and personal experiences (e.g. the last weekend, my last holiday).

\section{Strategies}

I can ask for attention.

I can indicate when I am following.

I can very simply ask somebody to repeat what they said.

\section{Language quality}

I can make myself understood using memorised phrases and single expressions.

I can link groups of words with simple connectors like "and", "but" and "because".

I can use some simple structures correctly.

I have a sufficient vocabulary for coping with simple everyday situations.

\section{Writing}

I can write short, simple notes and messages.

I can describe an event in simple sentences and report what happened when and where (for example a party or an accident).

I can write about aspects of my everyday life in simple phrases and sentences (people, places, job, school, family, hobbies).

I can fill in a questionnaire giving an account of my educational background, my job, my interests and my specific skills. 
I can briefly introduce myself in a letter with simple phrases and sentences (family, school, job, hobbies).

I can write a short letter using simple expressions for greeting, addressing, asking or thanking somebody.

I can write simple sentences, connecting them with words such as "and", "but" and "because". I can use the most important connecting words to indicate the chronological order of events (first, then, after, later).

\section{LEVEL B1}

\section{Listening}

I can follow clearly articulated speech directed at me in everyday conversation, though I sometimes have to ask for repetition of particular words and phrases.

I can generally follow the main points of extended discussion around me, provided speech is clearly articulated in standard dialect.

I can listen to a short narrative and form hypotheses about what will happen next.

I can understand the main points of radio news bulletins and simpler recorded material on topics of personal interest delivered relatively slowly and clearly.

I can catch the main points in TV programmes on familiar topics when the delivery is relatively slow and clear.

I can understand simple technical information, such as operating instructions for everyday equipment.

\section{Reading}

I can understand the main points in short newspaper articles about current and familiar topics.

I can read columns or interviews in newspapers and magazines in which someone takes a stand on a current topic or event and understand the overall meaning of the text.

I can guess the meaning of single unknown words from the context thus deducing the meaning of expressions if the topic is familiar.

I can skim short texts (for example news summaries) and find relevant facts and information (for example who has done what and where).

I can understand the most important information in short simple everyday information brochures.

I can understand simple messages and standard letters (for example from businesses, clubs or authorities).

In private letters I can understand those parts dealing with events, feelings and wishes well enough to correspond regularly with a pen friend.

I can understand the plot of a clearly structured story and recognise what the most important episodes and events are and what is significant about them.

\section{Spoken Interaction}


I can start, maintain and close simple face-to-face conversation on topics that are familiar or of personal interest.

I can maintain a conversation or discussion but may sometimes be difficult to follow when trying to say exactly what I would like to.

I can deal with most situations likely to arise when making travel arrangements through an agent or when actually travelling.

I can ask for and follow detailed directions.

I can express and respond to feelings such as surprise, happiness, sadness, interest and indifference.

I can give or seek personal views and opinions in an informal discussion with friends.

I can agree and disagree politely.

\section{Spoken Production}

I can narrate a story.

I can give detailed accounts of experience, describing feelings and reactions.

I can describe dreams, hopes and ambitions.

I can explain and give reasons for my plans, intentions and actions.

I can relate the plot of a book or film and describe my reactions.

I can paraphrase short written passages orally in a simple fashion, using the original text wording and ordering.

\section{Strategies}

I can repeat back part of what someone has said to confirm that we understand each other.

I can ask someone to clarify or elaborate what they have just said.

When I can't think of the word I want, I can use a simple word meaning something similar and invite "correction".

\section{Language quality}

I can keep a conversation going comprehensibly but have to pause to plan and correct what I am saying - especially when I talk freely for longer periods.

I can convey simple information of immediate relevance, getting across which point I feel is most important.

I have a sufficient vocabulary to express myself with some circumlocutions on most topics pertinent to my everyday life such as family, hobbies and interests, work, travel, and current events.

I can express myself reasonably accurately in familiar, predictable situations.

\section{Writing}

I can write simple connected texts on a range of topics within my field of interest and can express personal views and opinions.

I can write simple texts about experiences or events, for example about a trip, for a school newspaper or a club newsletter. 
I can write personal letters to friends or acquaintances asking for or giving them news and narrating events.

I can describe in a personal letter the plot of a film or a book or give an account of a concert. In a letter I can express feelings such as grief, happiness, interest, regret and sympathy. I can reply in written form to advertisements and ask for more complete or more specific information about products (for example a car or an academic course).

I can convey- via fax, e-mail or a circular - short, simple, factual information to friends or colleagues or ask for information in such a way.

I can write my CV in summary form.

\section{LEVEL B2}

\section{Listening}

I can understand in detail what is said to me in standard spoken language even in a noisy environment.

I can follow a lecture or talk within my own field, provided the subject matter is familiar and the presentation straightforward and clearly structured.

I can understand most radio documentaries delivered in standard language and can identify the speaker's mood, tone etc.

I can understand TV documentaries, live interviews, talk shows, plays and the majority of films in standard dialect.

I can understand the main ideas of propositionally and linguistically complex speech on both concrete and abstract topics delivered in a standard dialect, including technical discussions in my field of specialisation.

I I can use a variety of strategies to achieve comprehension, including listening for main points; checking comprehension by using contextual clues.

\section{Reading}

I can rapidly grasp the content and the significance of news, articles and reports on topics connected with my interests and my job, and decide if a closer reading is worthwhile.

I can read and understand articles and reports on current problems in which the writer express specific attitudes and points of view.

I can understand in detail texts within my field of interest or the area of my academic or professional speciality.

I can understand specialised articles outside my own field if I can occasionally check with a dictionary.

I can read reviews dealing with the content and criticism of cultural topics (films, theatre, books, concerts) and summarise the main points.

I can read letters on topics within my areas of academic or professional speciality or interest and grasp the most important points. 
I can quickly look through a manual (for example a computer program) and find and understand the relevant explanations and help for a specific problem.

I can understand in a narrative or play the motives for the character's actions and their consequences for the development of the plot.

\section{Spoken Interaction}

I can initiate, maintain and end discourse naturally with effective turn-taking.

I can exchange considerable quantities of detailed factual information on matters within my fields of interest.

I can convey degrees of emotion and highlight the personal significance of events and experiences.

I can engage in extended conversation in a clearly participatory fashion on most general topics.

I can account for and sustain my opinions in discussion by providing relevant explanations, arguments and comments.

I can help a discussion along on familiar ground confirming comprehension, inviting others in etc. I can carry out a prepared interview, checking and confirming information, following up interesting replies.

\section{Spoken Production}

I can give clear detailed descriptions on a wide range of subjects related to my fields of interest. I can understand and summarize orally short extracts from news items, interviews or documentaries containing opinions, argument and discussion.

I can understand and summarize orally the plot and sequence of events in an extract from a film or play.

I can construct a chain of reasoned argument, linking my ideas logically.

I can explain a viewpoint on a topical issue giving the advantages and disadvantages of various options.

I can speculate about causes, consequences, hypothetical situations.

\section{Strategies}

I can use standard phrases like "That's a difficult question to answer" to gain time and keep the turn while formulating what to say.

I can make a note of "favourite mistakes" and consciously monitor speech for them.

I can generally correct slips and errors if I become conscious of them or if they have led to misunderstandings.

\section{Language quality}

I can produce stretches of language with a fairly even tempo; although I can be hesitant as I search for expressions, there are few noticeably long pauses.

I can pass on detailed information reliably.

I have sufficient vocabulary to express myself on matters connected to my field and on most general topics. 
I can communicate with reasonable accuracy and can correct mistakes if they have led to misunderstandings.

\section{Writing}

I can write clear and detailed texts (compositions, reports or texts of presentations) on various topics related to my field of interest.

I can write summaries of articles on topics of general interests.

I can summarise information from different sources and media.

I can discuss a topic in a composition or "letter to the editor", giving reasons for or against a specific point of view.

I can develop an argument systematically in a composition or report, emphasising decisive points and including supporting details.

I can write about events and real or fictional experiences in a detailed and easily readable way. I can write a short review of a film or a book.

I can express in a personal letter different feelings or attitudes, and can report the news of the day making clear what - in my opinion - are the important aspects of an event.

\section{LEVEL C1}

\section{Listening}

I can follow extended speech even when it is not clearly structured and when relationships are only implied and not signalled explicitly.

I can understand a wide range of idiomatic expressions and colloquialisms, appreciating shifts in style and register.

I can extract specific information from even poor quality, audibly distorted public announcements, e.g. in a station, sports stadium etc.

I can understand complex technical information, such as operating instructions, specifications for familiar products and services.

I can understand lectures, talks and reports in my field of professional or academic interest even when they are propositionally and linguistically complex.

I can without too much effort understand films which contain a considerable degree of slang and idiomatic usage.

\section{Reading}

I can understand fairly long demanding texts and summarise them orally.

I can read complex reports, analyses and commentaries where opinions, viewpoints and connections are discussed.

I can extract information, ideas and opinions from highly specialised texts in my own field, for example research reports. 
I can understand complex instructions, for example for the use of a new piece of equipment, even of these are not related to my job or field of interest, provided I have enough time to reread them.

I can read contemporary literary texts with ease.

I can go beyond the concrete plot of a narrative and grasp implicit meanings, ideas and connections.

I can recognize the social, political or historical background of a literary work.

I can read any correspondence with occasional use of a dictionary.

\section{Spoken Interaction}

I can keep up with an animated conversation between native speakers.

I can use language fluently, accurately and effectively on a wide range of general, professional or academic topics.

I can use language flexibly and effectively for social purposes, including emotional, allusive and joking usage.

I can express my ideas and opinions clearly and precisely, and can present and respond to complex lines of reasoning convincingly.

\section{Spoken Production}

I can give clear, detailed descriptions of complex subjects.

I can orally summarise long, demanding texts.

I can give an extended description or account of something, integrating themes, developing particular points and concluding appropriately.

I can give a clearly developed presentation on a subject in my fields of professional interest, departing when necessary from the prepared text and following up spontaneously points raised by members of the audience.

\section{Strategies}

I can use fluently a variety of appropriate expressions to preface my remarks in order to get the floor, or to gain time and keep the floor while thinking.

I can relate own contribution skilfully to those of other speakers.

I can substitute an equivalent term for a word I can't recall without distracting the listener.

\section{Language quality}

I can express myself fluently and spontaneously, almost effortlessly. Only a conceptually difficult subject can hinder a natural, smooth flow of language.

I can produce clear, smoothly-flowing, well-structured speech, showing control over ways of developing what I want to say in order to link both my ideas and my expression of them into coherent text.

I have a good command of a broad vocabulary allowing gaps to be readily overcome with circumlocutions; I rarely have to search obviously for expressions or compromise on saying exactly what I want to. 
I can consistently maintain a high degree of grammatical accuracy; errors are rare and difficult to spot.

\section{Writing}

I can express myself in writing on a wide range of general or professional topics in a clear and user-friendly manner.

I can present a complex topic in a clear and well-structured way, highlighting the most important points, for example in a composition or a report.

I can present points of view in a comment on a topic or an event, underlining the main ideas and supporting my reasoning with detailed examples.

I can put together information from different sources and relate it in a coherent summary.

I can give a detailed description of experiences, feelings and events in a personal letter.

I can write formally correct letters, for example to complain or to take a stand in favour or against something.

I can write texts which show a high degree of grammatical correctness and vary my vocabulary and style according to addressee, the kind of text and the topic.

I can select a style appropriate to the reader in mind.

\section{LEVEL C2}

\section{Listening}

I have no difficulty in understanding any kind of spoken language, whether live or broadcast, even when at fast native speed, provided I have some time to get familiar with the accent.

\section{Reading}

I can recognize plays on words and appreciate texts whose real meaning is not explicit (for example irony, satire).

I can understand texts written in a very colloquial style and containing many idiomatic expressions or slang.

I can understand manuals, regulations and contracts even within unfamiliar fields.

I can understand contemporary and classical literary texts of different genres (poetry, prose, drama).

I can read texts such as literary columns or satirical glosses where much is said in an indirect and ambiguous way and which contain hidden value judgements.

I can recognize different stylistic means (puns, metaphors, symbols, connotations, ambiguity) and appreciate and evaluate their function within the text.

\section{Spoken Interaction}

I can take part effortlessly in all conversations and discussions with native speakers..

\section{Spoken Production}

I can summarise orally information from different sources, reconstructing arguments and accounts in a coherent presentation. 
I can present ideas and viewpoints in a very flexible manner in order to give emphasis, to differentiate and to eliminate ambiguity.

\section{Strategies}

I can backtrack and restructure around a difficulty so smoothly the interlocutor is hardly aware of it.

\section{Language quality}

I I can express myself naturally and effortlessly; I only need to pause occasionally on order to select precisely the right words.

- I can convey finer shades of meaning precisely by using, with reasonable accuracy, a wide range of expressions to qualify statements and pinpoint the extent to which something is the case.

] I have a good command of idiomatic expressions and colloquialisms with an awareness of implied meaning and meaning by association.

- I can consistently maintain grammatical control of complex language even when my attention is otherwise engaged.

\section{Writing}

I can write well-structured and easily readable reports and articles on complex topics.

In a report or an essay I can give a complete account of a topic based on research I have carried out, make a summary of the opinions of others, and give and evaluate detailed information and facts.

I can write a well-structured review of a paper or a project giving reasons for my opinion. I can write a critical review of cultural events (film, music, theatre, literature, radio, TV). I can write summaries of factual texts and literary works.

I can write narratives about experiences in a clear, fluent style appropriate to the genre. I can write clear, well-structured complex letters in an appropriate style, for example an application or request, an offer to authorities, superiors or commercial clients.

In a letter I can express myself in a consciously ironical, ambiguous and humorous way. 


\section{APPENDIX F1: Questionnaire (pre-testing stage)}

\section{OPĆE KOMPETENCIJE RAČUNALNO POSREDOVANE KOMUNIKACIJE (engl. computer-mediated communication - CMC)}

\begin{tabular}{|c|c|c|c|c|c|}
\hline $\begin{array}{l}\text { Molimo da svom odgovoru pridružite jedan od brojeva na ljestvici } \\
\qquad 1 \text { = uopće ne, a } 5=\text { u potpunosti da. }\end{array}$ & d 1 & do 5 & rI & & \\
\hline Sviđa li vam se komuniciranje putem računalnih medija? & 1 & 2 & 3 & 4 & 5 \\
\hline Jeste li motivirani za korištenje računala u svrhu komunikacije s drugima? & 1 & 2 & 3 & 4 & 5 \\
\hline Znate li komunicirati pomoću računala? & 1 & 2 & 3 & 4 & 5 \\
\hline $\begin{array}{l}\text { Znate li prilagoditi svoje poruke mediju kada komunicirate s nekim putem } \\
\text { računala? }\end{array}$ & 1 & 2 & 3 & 4 & 5 \\
\hline Smatrate li da su promjene u tehnologiji frustrirajuće? & 1 & 2 & 3 & 4 & 5 \\
\hline $\begin{array}{l}\text { Jeste li učinkovitiji pri korištenju alata za računalno posredovanu } \\
\text { komunikaciju nego pri korištenju drugih oblika komunikacije (npr. pisama)? }\end{array}$ & 1 & 2 & 3 & 4 & 5 \\
\hline $\begin{array}{l}\text { Jeste li učinkovitiji pri korištenju alata za računalno posredovanu } \\
\text { komunikaciju nego pri izravnoj interakciji? }\end{array}$ & 1 & 2 & 3 & 4 & 5 \\
\hline $\begin{array}{l}\text { Štede li tehnologije računalno posredovane komunikacije vaše vrijeme } \\
\text { tijekom rada? }\end{array}$ & 1 & 2 & 3 & 4 & 5 \\
\hline $\begin{array}{l}\text { Oslanjate li se na računalno posredovanu komunikaciju kako biste 'odradili' } \\
\text { svoj dan? }\end{array}$ & 1 & 2 & 3 & 4 & 5 \\
\hline
\end{tabular}

Koji od dolje navedenih alata koristite za računalno posredovanu komunikaciju i u kojoj mjeri? Koliko se ugodno osjećate prilikom njihovog korištenja? Molimo Vas da svom odgovoru pridružite jedan od brojeva na skali od 1 do 5 pri čemu 1 = uopće ne, a 5 = izrazito da.

\begin{tabular}{|l|c|c|c|c|c|c|c|c|c|c|}
\hline \begin{tabular}{|} 
ALATI ZA RAČUNALNO POSREDOVANU \\
KOMUNIKACIJU
\end{tabular} & \multicolumn{4}{c|}{$\begin{array}{c}\text { KOLIKO ČESTO KORISTITE } \\
\text { NAVEDENE ALATE }\end{array}$} & \multicolumn{3}{c|}{$\begin{array}{c}\text { KOLIKO SE UGODNO OSJEĆATE } \\
\text { PRILIKOM NJIHOVOG KORIŠTENJA }\end{array}$} \\
\hline elektronska pošta (e-mail) & 1 & 2 & 3 & 4 & 5 & 1 & 2 & 3 & 4 & 5 \\
\hline čavrljanje (chat) & 1 & 2 & 3 & 4 & 5 & 1 & 2 & 3 & 4 & 5 \\
\hline slanje istovremenih poruka (IM) & 1 & 2 & 3 & 4 & 5 & 1 & 2 & 3 & 4 & 5 \\
\hline $\begin{array}{l}\text { slanje kratkih tekstualnih poruka } \\
\text { (SMS) }\end{array}$ & 1 & 2 & 3 & 4 & 5 & 1 & 2 & 3 & 4 & 5 \\
\hline društveno umrežavanje & 1 & 2 & 3 & 4 & 5 & 1 & 2 & 3 & 4 & 5 \\
\hline forum & 1 & 2 & 3 & 4 & 5 & 1 & 2 & 3 & 4 & 5 \\
\hline wiki & 1 & 2 & 3 & 4 & 5 & 1 & 2 & 3 & 4 & 5 \\
\hline MMO igre & 1 & 2 & 3 & 4 & 5 & 1 & 2 & 3 & 4 & 5 \\
\hline weblog (blog) & 1 & 2 & 3 & 4 & 5 & 1 & 2 & 3 & 4 & 5 \\
\hline
\end{tabular}


II. TEHNOLOGIJA I AKADEMSKA ISKUSTVA

\begin{tabular}{|c|c|c|c|c|c|c|c|c|c|c|c|c|c|c|c|c|c|}
\hline (6) & \multicolumn{4}{|c|}{ PC } & \multicolumn{5}{|c|}{$\begin{array}{l}\text { prijenosno } \\
\text { računalo }\end{array}$} & \multicolumn{4}{|c|}{ tablet } & \multicolumn{4}{|c|}{$\begin{array}{l}\text { pametni } \\
\text { telefon }\end{array}$} \\
\hline $\begin{array}{l}\text { Koji uređaj koristite u akademske svrhe? Označite } \\
\text { jedan ili više odgovora. }\end{array}$ & & & & & & & & & & & & & & & & & \\
\hline $\begin{array}{l}\text { Koliko ga/ih često koristite označite na skali od } 1 \text { do } \\
5 \text { pri čemu } 1 \text { = uopće } n e .\end{array}$ & 1 & 2 & 3 & 45 & 51 & 2 & 3 & 4 & & 2 & 3 & & 5 & & 3 & & 5 \\
\hline $\begin{array}{l}\text { Koliko je važan uređaj kojeg koristite za akademske } \\
\text { svrhe označite na skali od } 1 \text { do } 5 \text { pri čemu } 1 \text { = uopće } \\
\text { nije važan. }\end{array}$ & 1 & 2 & 3 & 45 & 51 & 2 & 3 & 4 & & 12 & 3 & & 5 & & 3 & & 5 \\
\hline
\end{tabular}

\begin{tabular}{|c|c|c|c|c|c|c|c|c|c|}
\hline \multirow{4}{*}{\multicolumn{2}{|c|}{$\begin{array}{c}\text { Molimo Va } \\
1 \\
\text { uopće se } \\
\text { ne slažem } \\
\text { 1) Važno }\end{array}$}} & \multirow{3}{*}{\multicolumn{2}{|c|}{$\begin{array}{cc}\text { lajivo pročitate svaku tvrdnju i da na prilož } \\
2 & 3 \\
\text { ne slažem se } & \text { niti se slažem niti } \\
& \text { se ne slažem }\end{array}$}} & \multirow{3}{*}{\multicolumn{2}{|c|}{$\begin{array}{c}4 \\
\text { slažem se }\end{array}$}} & & \\
\hline & & & & & & & & & \\
\hline & & & & & & & & & \\
\hline & & astavnik kor & ve, najsuvremenije & ologije. & \multicolumn{4}{|c|}{\begin{tabular}{c}
5 \\
\multicolumn{1}{c}{$\begin{array}{c}\text { u potpunosti } \\
\text { se slažem }\end{array}$} \\
\end{tabular}} & 5 \\
\hline 2) & Najviš & naučiti kroz & ij bez e-komponen & & 1 & & & & 5 \\
\hline 3) & Najviš & naučiti kroz & s nekim e-komp & ma. & 1 & 2 & 3 & 4 & 5 \\
\hline 4) & Najviš & naučiti kroz & jij koji je u potpuno & mreži. & 1 & 2 & 3 & 4 & 5 \\
\hline
\end{tabular}

1) Koliko je vaših kolegija u prethodnom semestru bilo hibridnih kolegija (engl. blended courses) (s nekim e-komponentama i nekim komponentama izravnog učenja s nastavnikom)?

2) Koliko je vaših kolegija u prethodnom semestru bilo izričito e-kolegija?

3) Koji od sljedećih oblika komunikacije smatrate korisnima za učenje engleskog jezika? Označite jedan ili više odgovora (ispred oblika komunikacije). Označite u koju svrhu koristite svaki od oblika komunikacije.

\begin{tabular}{|c|c|c|c|c|}
\hline & $\begin{array}{c}\text { dopisivanje/razgovor } \\
\text { s kolegama }\end{array}$ & $\begin{array}{c}\text { dopisivanje/razgovor } \\
\text { s profesorom }\end{array}$ & $\begin{array}{c}\text { dopisivanje/razgovor } \\
\text { s poznanicima }\end{array}$ & $\begin{array}{l}\text { učenje na } \\
\text { daljinu }\end{array}$ \\
\hline e-mail & & & & \\
\hline SMS & & & & \\
\hline čavrljanje (chat) & & & & \\
\hline Twitter & & & & \\
\hline Facebook & & & & \\
\hline LinkedIn & & & & \\
\hline $\begin{array}{l}\text { izravna komunikacija } \\
\text { na internetu (Skype) }\end{array}$ & & & & \\
\hline razgovor telefonom & & & & \\
\hline osobna interakcija & & & & \\
\hline $\begin{array}{l}\text { platforma za učenje } \\
\text { (npr. Moodle) }\end{array}$ & & & & \\
\hline drugo (navedite koje) & & & & \\
\hline
\end{tabular}


4) Smatrate li da je Facebook koristan za komunikaciju i interakciju s drugim studentima o kolegijima izvan učionice?

\section{$D A-N E$}

5) Smatrate li da je Facebook koristan za komunikaciju i interakciju s nastavnikom o kolegijima izvan učionice?

$D A-N E$

6) Smatrate li da je forum koristan za komunikaciju i interakciju s drugim studentima o kolegijima izvan učionice?

\section{$D A-N E$}

\begin{tabular}{|l|l|l|l|l|l|}
\hline \multicolumn{5}{|c|}{ Molimo da svom odgovoru pridružite jedan od brojeva na ljestvici od 1 do 5 pri čemu } \\
$1=$ uopće ne, a 5 = u potpunosti da. & 1 & 2 & 3 & 4 & 5 \\
\hline $\begin{array}{l}\text { Biste li bili aktivnije uključeni u nastavu kad bi se tehnologija više koristila u } \\
\text { nastavi engleskog jezika? }\end{array}$ & 1 & 2 & 3 & 4 & 5 \\
\hline $\begin{array}{l}\text { Izostajete li s nastave kada su materijali koji se koriste u nastavi dostupni na } \\
\text { mreži? }\end{array}$ & 1 & 2 & 3 & 4 & 5 \\
\hline $\begin{array}{l}\text { Smatrate li da vas uporaba tehnologije bolje priprema za buduće obrazovne } \\
\text { planove, npr. prebacivanje na neki drugi studij? }\end{array}$ & 1 & 2 & 3 & 4 & 5 \\
\hline Pomaže li vam korištenje tehnologije na fakultetu u vašem poslu? & 1 & 2 & 3 & 4 & 5 \\
\hline Smatrate li da tehnologija povećava razinu poučavanja? & & & \\
\hline
\end{tabular}

\section{MOODLE}

Kojom biste brojkom ocijenili svoje znanje i vještine u pogledu korištenja Moodle-a na ljestvici od 1 do 5 , gdje je 1 = vrlo nisko i 5 = vrlo visoko?

\section{UPUTA: Molimo da zaokružite jedan od ponuđenih odgovora.}

1) Koliko često koristite Moodle?
a) uopće ne
b) rjeđe od jednom tjedno
c) otprilike jednom tjedno
d) nekoliko puta tjedno
e) svakodnevno

2) U koje svrhe koristite Moodle? (Moguće je označiti više odgovora.)
a) prikupljanje informacija o pojedinom
e) pisanje testova kolegiju (ispiti, konzultacije i sl.)
f) izrada wikija
b) preuzimanje materijala s nastave
g) komunikacija s nastavnikom
c) sudjelovanje u forumu
h) komunikacija s kolegama
d) izrada/predaja zadaće

3) Sviđa li vam se koristiti Moodle? DA - NE

4) Smatrate li da je Moodle koristan za učenje? DA - NE

5) Povećava li korištenje Moodle-a u svrhu učenja vašu produktivnost? $D A-N E$

6) Smatrate li da je lako koristiti Moodle? $D A-N E$

7) Čini li Moodle učenje zanimljivijim? $\quad D A-N E$

8) Jeste li spremni koristiti Moodle nekoliko puta tjedno za nastavu Engleskog jezika? DA - NE 


\section{UČENJE NA DAUINU/E-UČENJE}

UPUTA: Molimo da zaokružite jedan od ponuđenih odgovora.

1) Jeste li dosada imali iskustva s učenjem na daljinu? $\quad \boldsymbol{D A}-\boldsymbol{N E}$

2) Biste li pratili kolegij Engleski jezik u potpunosti kao e-kolegij? $\quad \boldsymbol{D A}-\boldsymbol{N E}$

3) Biste li bili spremni odraditi neke tjedne zadatke vezane uz učenje jezika na mreži ako to od vas zatraži nastavnik? $\quad D A-N E$

4) Prema vašem mišljenju, je li moguće studirati i položiti ispit iz nekog predmeta bez fizičke prisutnosti u razredu? $\quad D A-N E$

5) Biste li bili zainteresirani za praćenje kolegija iz vlastitog doma? $\quad \boldsymbol{D A}-\boldsymbol{N E}$

6) Smatrate li da je učenje na daljinu zahtjevnije od fizičke prisutnosti u razredu? $\quad D A-N E$

7) Smatrate li da ste dobili jednako znanje kao i u razredu? $\quad \boldsymbol{D A}-\mathbf{N E}$

8) Čemu od navedenog biste dali prednost:

a) izravnom učenju

b) učenju na daljinu?

9) Prema vašem mišljenju, u kojoj se mjeri učenjem na daljinu mogla razviti pojedina vještina? Molimo da svom odgovoru pridružite jedan od brojeva na ljestvici od 1 do 5 , pri čemu $1=$ uopće ne, a 5 = u potpunosti da.

$\begin{array}{llllll}\text { a) govor } & 1 & 2 & 3 & 4 & 5 \\ \text { b) čitanje } & 1 & 2 & 3 & 4 & 5 \\ \text { c) pisanje } & 1 & 2 & 3 & 4 & 5 \\ \text { d) slušanje } & 1 & 2 & 3 & 4 & 5\end{array}$

10) Koju od vještina biste htjeli razviti uz pomoć učenja na daljinu?
a) govor
b) čitanje
c) pisanje
d) slušanje

\section{OSOBNI PODACI}

Koji ste studij upisali?

Jeste li redovni ili izvanredni student?

Koliko ste godina učili/učite engleski jezik? (Ako ga niste učili u formalnom okruženju, upišite oznaku 'O').

Spol: $M$ Ž

Koliko imate godina? 


\title{
APPENDIX F2: Questionnaire (post-testing stage with additional questions)
}

\author{
I. OPĆE KOMPETENCIJE RAČUNALNO POSREDOVANE KOMUNIKACIJE (engl. computer-mediated \\ communication - CMC)
}

\begin{tabular}{|c|c|c|c|c|c|}
\hline $\begin{array}{l}\text { Molimo da svom odgovoru pridružite jedan od brojeva na ljestvici } \\
\qquad 1 \text { = uopće ne, a } 5=\text { u potpunosti da. }\end{array}$ & d 1 & do 5 & rI & & \\
\hline Sviđa li vam se komuniciranje putem računalnih medija? & 1 & 2 & 3 & 4 & 5 \\
\hline Jeste li motivirani za korištenje računala u svrhu komunikacije s drugima? & 1 & 2 & 3 & 4 & 5 \\
\hline Znate li komunicirati pomoću računala? & 1 & 2 & 3 & 4 & 5 \\
\hline $\begin{array}{l}\text { Znate li prilagoditi svoje poruke mediju kada komunicirate s nekim putem } \\
\text { računala? }\end{array}$ & 1 & 2 & 3 & 4 & 5 \\
\hline Smatrate li da su promjene u tehnologiji frustrirajuće? & 1 & 2 & 3 & 4 & 5 \\
\hline $\begin{array}{l}\text { Jeste li učinkovitiji pri korištenju alata za računalno posredovanu } \\
\text { komunikaciju nego pri korištenju drugih oblika komunikacije (npr. pisama)? }\end{array}$ & 1 & 2 & 3 & 4 & 5 \\
\hline $\begin{array}{l}\text { Jeste li učinkovitiji pri korištenju alata za računalno posredovanu } \\
\text { komunikaciju nego pri izravnoj interakciji? }\end{array}$ & 1 & 2 & 3 & 4 & 5 \\
\hline $\begin{array}{l}\text { Štede li tehnologije računalno posredovane komunikacije vaše vrijeme } \\
\text { tijekom rada? }\end{array}$ & 1 & 2 & 3 & 4 & 5 \\
\hline $\begin{array}{l}\text { Oslanjate li se na računalno posredovanu komunikaciju kako biste 'odradili' } \\
\text { svoj dan? }\end{array}$ & 1 & 2 & 3 & 4 & 5 \\
\hline
\end{tabular}

Koji od dolje navedenih alata koristite za računalno posredovanu komunikaciju i u kojoj mjeri? Koliko se ugodno osjećate prilikom njihovog korištenja? Molimo Vas da svom odgovoru pridružite jedan od brojeva na skali od 1 do 5 pri čemu 1 = uopće ne, a 5 = izrazito da.

\begin{tabular}{|c|c|c|c|c|c|c|c|c|c|c|}
\hline $\begin{array}{l}\text { ALATI ZA RAČUNALNO POSREDOVANU } \\
\text { KOMUNIKACIJU }\end{array}$ & \multicolumn{5}{|c|}{$\begin{array}{l}\text { KOLIKO ČESTO KORISTITE } \\
\text { NAVEDENE ALATE }\end{array}$} & \multicolumn{5}{|c|}{$\begin{array}{l}\text { KOLIKO SE UGODNO OSJEĆATE } \\
\text { PRILIKOM NJIHOVOG KORIŠTENJA }\end{array}$} \\
\hline elektronska pošta (e-mail) & 1 & 2 & 3 & 4 & 5 & 1 & 2 & 3 & 4 & 5 \\
\hline čavrljanje (chat) & 1 & 2 & 3 & 4 & 5 & 1 & 2 & 3 & 4 & 5 \\
\hline slanje istovremenih poruka (IM) & 1 & 2 & 3 & 4 & 5 & 1 & 2 & 3 & 4 & 5 \\
\hline $\begin{array}{l}\text { slanje kratkih tekstualnih poruka } \\
\text { (SMS) }\end{array}$ & 1 & 2 & 3 & 4 & 5 & 1 & 2 & 3 & 4 & 5 \\
\hline društveno umrežavanje & 1 & 2 & 3 & 4 & 5 & 1 & 2 & 3 & 4 & 5 \\
\hline forum & 1 & 2 & 3 & 4 & 5 & 1 & 2 & 3 & 4 & 5 \\
\hline wiki & 1 & 2 & 3 & 4 & 5 & 1 & 2 & 3 & 4 & 5 \\
\hline MMO igre & 1 & 2 & 3 & 4 & 5 & 1 & 2 & 3 & 4 & 5 \\
\hline weblog (blog) & 1 & 2 & 3 & 4 & 5 & 1 & 2 & 3 & 4 & 5 \\
\hline
\end{tabular}




\section{TEHNOLOGIJA I AKADEMSKA ISKUSTVA}

\begin{tabular}{|c|c|c|c|c|c|c|c|c|c|c|c|c|c|c|c|c|}
\hline & \multicolumn{4}{|c|}{ PC } & \multicolumn{4}{|c|}{$\begin{array}{l}\text { prijenosno } \\
\text { računalo }\end{array}$} & \multicolumn{4}{|c|}{ tablet } & \multicolumn{4}{|c|}{$\begin{array}{l}\text { pametni } \\
\text { telefon }\end{array}$} \\
\hline $\begin{array}{l}\text { Koji uređaj koristite u akademske svrhe? Označite } \\
\text { jedan ili više odgovora. }\end{array}$ & & & & & & & & & & & & & & & & \\
\hline $\begin{array}{l}\text { Koliko ga/ih često koristite označite na skali od } 1 \text { do } \\
5 \text { pri čemu } 1 \text { = uopće } n e \text {. }\end{array}$ & 1 & 23 & 4 & & & 23 & 4 & 5 & 12 & 3 & & 5 & & 3 & & 5 \\
\hline $\begin{array}{l}\text { Koliko je važan uređaj kojeg koristite za akademske } \\
\text { svrhe označite na skali od } 1 \text { do } 5 \text { pri čemu } 1 \text { = uopće } \\
\text { nije važan. }\end{array}$ & 12 & 23 & 4 & 5 & 12 & 23 & & 5 & 12 & 3 & 4 & 5 & & 3 & 4 & 5 \\
\hline
\end{tabular}

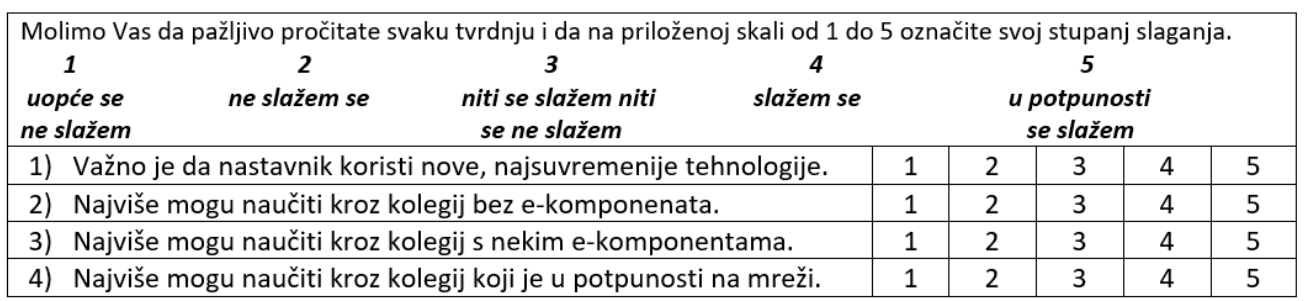

1) Koliko je vaših kolegija u prethodnom semestru bilo hibridnih kolegija (engl. blended courses) (s nekim e-komponentama i nekim komponentama izravnog učenja s nastavnikom)?

2) Koliko je vaših kolegija u prethodnom semestru bilo izričito e-kolegija?

3) Koji od sljedećih oblika komunikacije smatrate korisnima za učenje engleskog jezika? Označite jedan ili više odgovora (ispred oblika komunikacije). Označite u koju svrhu koristite svaki od oblika komunikacije.

\begin{tabular}{|l|l|l|l|l|l|}
\cline { 2 - 5 } \multicolumn{2}{l|}{} & $\begin{array}{c}\text { dopisivanje/razgovor } \\
\text { s kolegama }\end{array}$ & $\begin{array}{c}\text { dopisivanje/razgovor } \\
\text { s profesorom }\end{array}$ & $\begin{array}{c}\text { dopisivanje/razgovor } \\
\text { s poznanicima }\end{array}$ & $\begin{array}{c}\text { učenje na } \\
\text { daljinu }\end{array}$ \\
\hline & SMS & & & & \\
\hline & čavrljanje (chat) & & & & \\
\hline & Twitter & & & & \\
\hline & Facebook & & & \\
\hline & Linkedln & & & \\
\hline & $\begin{array}{l}\text { izravna komunikacija } \\
\text { na internetu (Skype) }\end{array}$ & & & & \\
\hline razgovor telefonom & & & & \\
\hline & $\begin{array}{l}\text { osobna interakcija } \\
\text { platforma za učenje } \\
\text { (npr. Moodle) }\end{array}$ & & & & \\
\hline drugo (navedite koje) & & & & \\
\hline
\end{tabular}


4) Smatrate li da je Facebook koristan za komunikaciju i interakciju s drugim studentima o kolegijima izvan učionice?

$D A-N E$

5) Smatrate li da je Facebook koristan za komunikaciju i interakciju s nastavnikom o kolegijima izvan učionice?

6) Smatrate li da je forum koristan za komunikaciju i interakciju s drugim studentima o kolegijima izvan učionice?

\section{$D A-N E$}

\begin{tabular}{|l|l|l|l|l|l|}
\hline \multicolumn{4}{|c|}{ Molimo da svom odgovoru pridružite jedan od brojeva na ljestvici od 1 do 5 pri čemu } \\
1 1 uopće ne, a 5 = u potpunosti da. & 1 & 2 & 3 & 4 & 5 \\
\hline $\begin{array}{l}\text { Biste li bili aktivnije uključeni u nastavu kad bi se tehnologija više koristila u } \\
\text { nastavi engleskog jezika? }\end{array}$ & 1 & 2 & 3 & 4 & 5 \\
\hline $\begin{array}{l}\text { Izostajete li s nastave kada su materijali koji se koriste u nastavi dostupni na } \\
\text { mreži? }\end{array}$ & 1 & 2 & 3 & 4 & 5 \\
\hline $\begin{array}{l}\text { Smatrate li da vas uporaba tehnologije bolje priprema za buduće obrazovne } \\
\text { planove, npr. prebacivanje na neki drugi studij? }\end{array}$ & 1 & 2 & 3 & 4 & 5 \\
\hline Pomaže li vam korištenje tehnologije na fakultetu u vašem poslu? & 1 & 2 & 3 & 4 & 5 \\
\hline Smatrate li da tehnologija povećava razinu poučavanja? &
\end{tabular}




\section{MOODLE}

Kojom biste brojkom ocijenili svoje znanje i vještine u pogledu korištenja Moodle-a na ljestvici od 1 do 5 , gdje je 1 = vrlo nisko i 5 = vrlo visoko?

\section{UPUTA: Molimo da zaokružite jedan od ponuđenih odgovora.}

1) Koliko često koristite Moodle?
a) uopće ne
b) rjeđe od jednom tjedno
c) otprilike jednom tjedno
d) nekoliko puta tjedno
e) svakodnevno

2) U koje svrhe koristite Moodle? (Moguće je označiti više odgovora.)
a) prikupljanje informacija o pojedinom
e) pisanje testova kolegiju (ispiti, konzultacije i sl.)
f) izrada wikija
b) preuzimanje materijala s nastave
g) komunikacija s nastavnikom
c) sudjelovanje $u$ forumu
h) komunikacija s kolegama
d) izrada/predaja zadaće

3) Sviđa li vam se koristiti Moodle? DA - NE

4) Smatrate li da je Moodle koristan za učenje? DA - NE

5) Povećava li korištenje Moodle-a u svrhu učenja vašu produktivnost? $D A-N E$

6) Smatrate li da je lako koristiti Moodle? $\boldsymbol{D A}-\boldsymbol{N E}$

7) Čini li Moodle učenje zanimljivijim? DA - NE

8) Jeste li spremni koristiti Moodle nekoliko puta tjedno za nastavu Engleskog jezika? DA - NE

\section{UČENJE NA DALINU/E-UČENJE}

UPUTA: Molimo da zaokružite jedan od ponuđenih odgovora.

1) Jeste li dosada imali iskustva s učenjem na daljinu? $\quad \boldsymbol{D A}-\boldsymbol{N E}$

2) Biste li pratili kolegij Engleski jezik u potpunosti kao e-kolegij? $\quad \boldsymbol{D A}-\boldsymbol{N E}$

3) Biste li bili spremni odraditi neke tjedne zadatke vezane uz učenje jezika na mreži ako to od vas zatraži nastavnik? $\quad \boldsymbol{D A}-\mathbf{N E}$

4) Prema vašem mišljenju, je li moguće studirati i položiti ispit iz nekog predmeta bez fizičke prisutnosti u razredu? $\quad \boldsymbol{D A}-\boldsymbol{N E}$

5) Biste li bili zainteresirani za praćenje kolegija iz vlastitog doma? $\quad D A-N E$

6) Smatrate li da je učenje na daljinu zahtjevnije od fizičke prisutnosti u razredu? $\quad \boldsymbol{D A}-\boldsymbol{N E}$

7) Smatrate li da ste dobili jednako znanje kao i u razredu? $\quad \boldsymbol{D A}-\boldsymbol{N E}$

8) Čemu od navedenog biste dali prednost:

a) izravnom učenju

b) učenju na daljinu?

9) Prema vašem mišljenju, u kojoj se mjeri učenjem na daljinu mogla razviti pojedina vještina? Molimo da svom odgovoru pridružite jedan od brojeva na ljestvici od 1 do 5 , pri čemu $1=$ uopće ne, a 5 = u potpunosti da.

$\begin{array}{llllll}\text { a) govor } & 1 & 2 & 3 & 4 & 5 \\ \text { b) čitanje } & 1 & 2 & 3 & 4 & 5 \\ \text { c) pisanje } & 1 & 2 & 3 & 4 & 5 \\ \text { d) slušanje } & 1 & 2 & 3 & 4 & 5\end{array}$


10) Koju od vještina biste htjeli razviti uz pomoć učenja na daljinu?
a) govor
b) čitanje
c) pisanje
d) slušanje

11) Da li Vam je nedostajalo što niste bili fizički prisutni na nastavi čitavo vrijeme? $\boldsymbol{D A}-\boldsymbol{N E}$

12) Da li Vam je nedostajao redovni kontakt s nastavnikom? DA - NE

13) Smatrate li da ste napredovali u znanju engleskog jezika? DA - NE

14) U kojem obliku nastave ste dobili bolju povratnu informaciju? Podcrtajte jedno od ponuđenog. izravno učenje učenje na daljinu

15) Smatrate li da se učenjem na daljinu razvija samostalnost u učenju? $\boldsymbol{D A}-\boldsymbol{N E}$

16) Koliko Vam je važno da sami određujete tempo učenja? Molimo da svom odgovoru pridružite jedan od brojeva na ljestvici od 1 do 5 pri čemu 1 = uopće ne, a 5 = u potpunosti da.

2

34

5

\section{OSOBNI PODACI}

Koji ste studij upisali?

Jeste li redovni ili izvanredni student?

Koliko ste godina učili/učite engleski jezik? (Ako ga niste učili u formalnom okruženju, upišite oznaku 'O').

Spol: $M \check{Z}$

Koliko imate godina? 


\section{Author's Biography}

Ivana Grabar was born in 1978 in Varaždin. Upon completing her primary and secondary education in Varaždin, she enrolled at the Faculty of Humanities and Social Sciences, University of Zagreb. She graduated in 2004 at the departments of English Language and Literature and Italian Language and Literature. In 1999, she started working as a teacher of English and Italian in a foreign languages school, first in Zagreb then in Varaždin. In December 2009, she started working at the Polytechnic of Varaždin (now University North), where she taught English at several departments, first as an assistant and later as a lecturer. In July 2015, she was elected into the title of senior lecturer. She teaches General English and Business English at undergraduate study programmes at the departments of Mechanical Engineering, Journalism, Media Design, and Business and Management. She has published several professional and scientific papers and presented them at national and international conferences related to philology and business. As an invited speaker she participated in the Methodical School in Novosibirsk, Russia, and she gave a lecture on ESP to the graduate students of English at the State Pedagogical University in Novosibirsk, Russia. In September 2014, she participated in the Erasmus program at the KYAMK University in Kotka, Finland. In addition to her teaching and research activities she translates as a court interpreter for English and Italian. She is a member of the Association of Court Interpreters and Translators and of the Association of LSP Teachers at Higher Education Institutions. She was awarded a written testimonial by the Rector of University North for outstanding achievement in the academic year 2013/14 based on the results of student surveys. She is married and a mother of two.

\section{Publications}

Grabar, I.; Senjan, E.; Mandić, A. (2019). Causes of Inadequate Internal Communication in Organization. In M. Drljača (ed.), Zbornik radova 20. međunarodnog simpozija o kvaliteti: KVALITETA - JUČER, DANAS, SUTRA (pp. 79-86). Zagreb: Hrvatsko društvo menadžera kvalitete. 
Grabar, I.; Zlatić, S.; Globočnik Žunac, A. (2018). Freelancers: Independent and Free in Their Business Management. SGEM 2018 Conference Proceedings,1.5 (pp. 433-438). Sofia: STEF92 Technology Ltd.

Mesmar Žegarac, L.; Grabar, I. (2018). Engleski jezik na visokoškolskim ustanovama u odnosu na stvarni svijet - što poučavamo? Educa, časopis za obrazovanje, nauku i kulturu, XI (11), pp. 337340.

Grabar, I.; Kolednjak, M. (2018). Značaj i vrijednost poučavanja stranih jezika i etike u području turizma. In N. Breslauer (ed.), Zbornik radova $s$ 5. međunarodne konferencije Inovacije, tehnologije, edukacija i menadžment, 1 (pp.61-66). Čakovec: Međimursko veleučilište u Čakovcu. Grabar, I. (2017). Planning an English Language Course for University Employees. Topical Issues of Philology and Methods of Foreign Language Teaching, 11, pp. 163-165.

Kolednjak, M. Egorychev, A. M.; Grabar, I. (2017). The point of ethics and language in the media - utopian hope or real reality? Novosibirsk State Pedagogical University Bulletin, 7(4), pp. 125135. doi:10.15293/2226-3365.1704.08

Grabar, I.; Glavaš, T. (2016). Foreign language learning and technology: differences in learners' perspective and beliefs in relation to the age factor. Novosibirsk State Pedagogical University Bulletin, 6(4), pp. 50-58. doi:10.15293/2226-3365.1604.05

Grabar, I.; Kostina, E. A.; Kolednjak, M. (2016). Love and Hatred in Two Languages: CrossCultural Analysis. Journal of Foreign Language Teaching and Applied Linguistics (J-FLTAL), 3(3), pp. 33-42.

Kostina, E. A.; Grabar, I.; Kolednjak, M.; Khoroshilova, S. (2015). Cross-cultural analysis of a value and an anti- value through different languages. SGEM 2015 Conference Proceedings (pp.401-408). Sofia: STEF92 Technology Ltd.

Grabar, I.; Rajh, I. (2014). Using Learning Management Systems in ESP: Students' Perceptions and Actual Benefits. In N. Gajšt, A. Plos, Vičič P. (eds.), Proceedings of the 7th International 
Language Conference on the Importance of Learning Professional Foreign Languages for Communication Between Cultures 2014 (pp. 64-75). Maribor: University of Maribor, Faculty of Economics and Business.

Kolednjak, M.; Grabar, I. (2014). Engineering Ethics in the Process of Problem-Solving. Tehnički glasnik, 8(2), pp. 192-196.

Ordulj, A.; Grabar, I. (2014). Shyness and Foreign Language Anxiety. In A. Akbarov (ed.), Proceedings of the 2nd International Conference on Foreign Language Teaching and Applied Linguistics "Linguistics, culture and identity in foreign language education" (pp. 215-222). Sarajevo: International Burch University.

Ordulj, A.; Grabar, I. (2012). Foreign Language Anxiety in Learning Italian as a Foreign Language. Proceedings of the International Scientific Professional Internet Conference "Actual problems of philology and methods of teaching foreign languages" (pp. 172-180). Novosibirsk: NSPU.

Grabar, I. (2012). The Influence of the Standardization of Learning Outcomes on Foreign Language Teaching. Proceedings of the International Scientific Professional Internet Conference "Actual problems of philology and methods of teaching foreign languages" (pp. 109-117). Novosibirsk: NSPU.

Engler, T.; Grabar, I. (2012). Uporaba afekcijskih potencijala u svrhu habitualizacije stranojezičnih kompetencija u sklopu nastave stranoga jezika na visokoškolskim stučnim ustanovama. In L. Pon, V. Karabalić, Sanja C. (eds.), Aktualna istraživanja u primijenjenoj ligvistici (pp. 303-322). Osijek: HDPL.

Grabar, I.; Engler, T. (2011). Synergetic Approach to Teaching Foreign Languages at Undergraduate Technical Institutions. Advances in Business-Related Scientific Research Journal, 2 (1), pp. 89-99. 